\title{
Towards improved scaffolds for bone tissue engineering
}

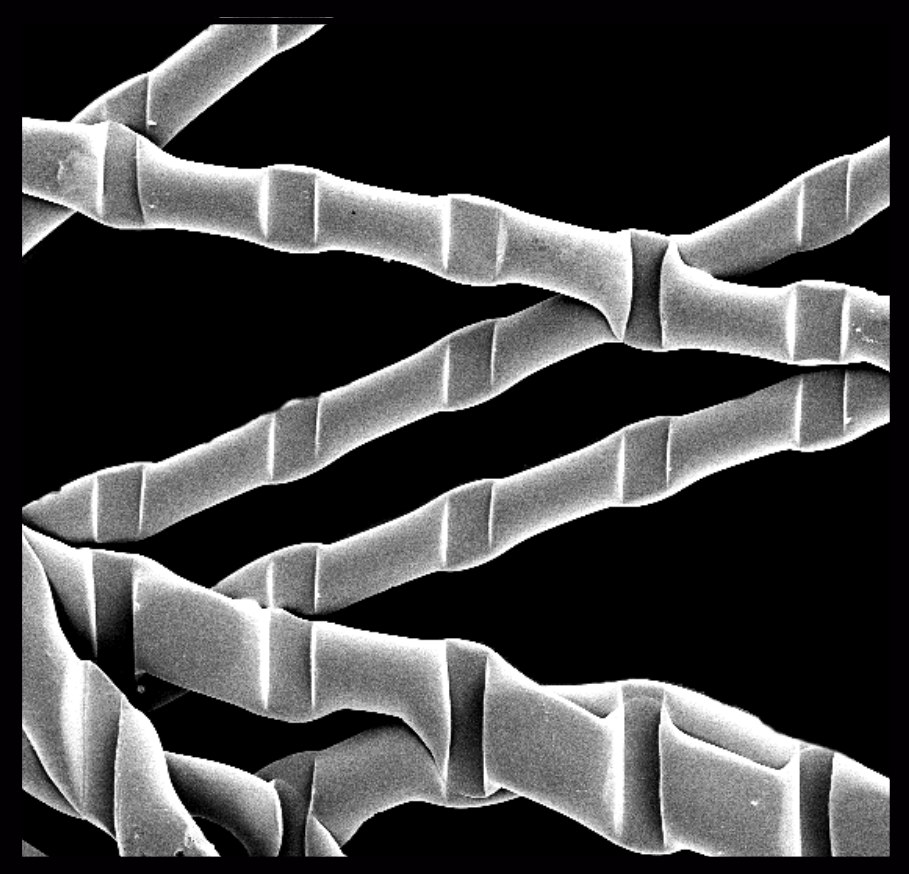

Anandkumar Nandakumar 


\section{TOWARDS IMPROVED SCAFFOLDS FOR BONE TISSUE ENGINEERING}

ANANDKUMAR NANDAKUMAR 


\section{Members of the Commitee:}

Chairman: $\quad$ Prof. Dr. G. van der Steenhoven University of Twente

Promotor: Prof. Dr. C.A. van Blitterswijk University of Twente

Assistant Promotor: Dr. P. Habibovic University of Twente

Referent: Dr. L. Moroni University of Twente

Members: Prof. Dr. P. Dubruel University of Gent

Prof. Dr. P.J. Dijkstra Soochow University

Prof. Dr. ir. H.F.J.M. Koopman University of Twente

Dr. D. Stamatialis University of Twente

Towards improved scaffolds for bone tissue engineering

\section{Anandkumar Nandakumar}

The research described in this thesis was performed at the department of Tissue Regeneration, MIRA Institute and the Faculty of Science and Technology, University of Twente, PO Box 217, 7500 AE, Enschede, The Netherlands.

Anna Foundation|NOREF provided financial support for the publication of this thesis

The publication of this thesis was sponsored by:
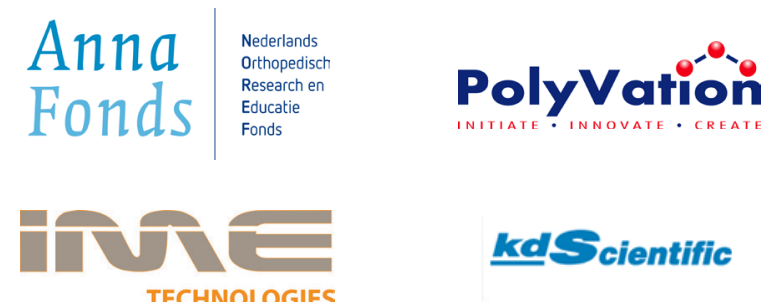

kalscientific

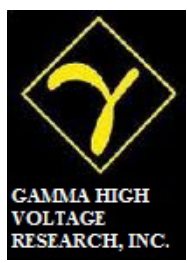

(C) Anandkumar Nandakumar, Eindhoven, The Netherlands, 2012. Neither this book nor its parts may be reproduced without written permission of the author.

ISBN: 978-90-365-3341-6

Cover design: The cover was designed by the author. The front cover illustrates the imprinting of electrospun fibres with microgrooves (chapter 7) and the back cover contains SEM images obtained during various experiments in this thesis

Printed by: WÖhrmann Print Service, Zutphen, The Netherlands 


\section{TOW ARDS IMPROVED SCAFFOLDS FOR BONE TISSUE ENGINEERING}

\section{DISSERTATION}

to obtain

the degree of doctor at the University of Twente,

on the authority of the rector magnificus,

Prof. Dr. H. Brinksma,

on account of the decision of the graduation committee,

to be publicly defended

on Thursday, April 19, 2012 at 12:45

by

Anandkumar Nandakumar

Born on September 29 $9^{\text {th }}, 1981$

Chennai (Madras), India 
This dissertation has been approved by

Promotor: Prof. Dr. C.A.van. Blitterswijk

Assitant Promotor: Dr. P. Habibovic

(C) Anandkumar Nandakumar, 2012

ISBN: 978-90-365-3341-6 
To Renuka 

There is no secret ingredient.

- Mr. Ping (KungFu Panda) 


\section{LIST OF PUBLICATIONS}

\section{This thesis is based on the following publications:}

Nandakumar A, Yang L, Habibovic P, van Blitterswijk CA. Calcium phosphate coated electrospun fiber matrices as scaffolds for bone tissue engineering. Langmuir. 2010 May 18;26(10):7380-7

Nandakumar A, Fernandes H, de Boer J, Moroni L, Habibovic P, van Blitterswijk CA. Fabrication of bioactive composite scaffolds by electrospinning for bone regeneration. Macromolecular Bioscience. 2010 Nov 10;10(11):136573

Nandakumar A, Barradas A, de Boer J, Moroni L, van Blitterswijk CA, Habibovic P. Bioactive hierarchical scaffolds for bone tissue engineering. Submitted.

Nandakumar A, Cruz C, Mentink A, Moroni L, van Blitterswijk CA, Habibovic P. Monolithic and assembled polymer-hydroxyapatite composites for bone tissue engineering. Submitted.

Nandakumar A, Santos D, Mentink A, Auffermann N, van der Werf K, Bennink M, Moroni L, van Blitterswijk CA, Habibovic P. Modulation of nanoscale roughness and chemistry by plasma treatment influences osteogenic differentiation of human mesenchymal stromal cells. Submitted.

Nandakumar A, Truckenmüller R, Santos D, Auffermann N, Habibovic P, van Blitterswijk CA, Moroni L. A fast process for imprinting micro- and nanopatterns on electrospun fibre meshes at physiological temperatures. Submitted.

\section{Other publications:}

Catros S, Guillemot F, Nandakumar A, Ziane S, Moroni L, Habibovic P, van Blitterswijk CA, Rousseau B, Chassande O, Ame' de'e J, Fricain J. Layer-byLayer tissue microfabrication supports cell proliferation in vitro and in vivo. Tissue Engineering: Part C Methods. 2012 Jan;18(1):62-70. Epub 2011 Nov 7

Rivron NC, Raiss CC, Liu J, Nandakumar A, Sticht C, Gretz N, Truck- 
enmüller R, Rouwkema J, van Blitterswijk CA. Sonic Hedgehog-activated engineered blood vessels enhance bone tissue formation. Proceedings of the National Academy of Sciences. 2012 Mar 2. [Epub ahead of print]

Nandakumar A, Cruz C, Mentink A, Moroni L, van Blitterswijk CA, Habibovic P Rapid prototyped Magnesium-substituted HA / PEOT-PBT composites for bone tissue engineering. Manuscript in progress. 



\section{TABLE OF CONTENTS}

Summary

Samenvatting

Chapter 1

General introduction

$\operatorname{Part} \mathbf{A}$

Incorporation of calcium-phosphates in polymeric scaffolds: Coatings, Composites and Assembly

Chapter 2

Calcium phosphate coated electrospun fibre matrices as scaffolds for bone tissue engineering

Chapter 3

Bioactive hierarchical scaffolds for bone tissue engineering

Chapter 4

Fabrication of bioactive composite scaffolds by electrospinning for bone regeneration

Chapter 5

Monolithic and assembled polymer-hydroxyapatite composites for bone tissue engineering

\section{Part B}

Surface modifications for altering cell behaviour

\section{Chapter 6}

Modulation of nanoscale surface roughness and chemistry by plasma treatment influences osteogenic differentiation of human mesenchymal stromal cells

Chapter 7

A fast process for imprinting micro- and nanopatterns on electrospun fibre meshes at physiological temperatures

Chapter 8

General discussion and conclusions 



\section{SUMMARY}

Tissue engineering aims to restore, maintain or improve tissue function of damaged tissues. In a classical set-up, a scaffold functions as a supporting structure and a carrier for growth factors and/or cells. Human mesenchymal stromal cells (hMSCs) have the ability to differentiate into bone, cartilage and fat lineage and provide an attractive source for cell-based tissue engineering approaches. This thesis explores a combination of various biomaterials, scaffold fabrication technologies and surface treatment techniques to create improved scaffolds for bone tissue engineering.

Chapter 1 introduces the concept of tissue engineering and explains the need for bone tissue engineering. Various approaches and technologies used for bone tissue engineering are discussed and the aims of the thesis are presented.

Part A (chapters 2-5) focuses mainly on introducing calcium phosphate to polymeric scaffolds by different methods - coatings, preparation of composite scaffolds and hybrid structures. In chapter 2, a calcium phosphate coating was applied using a biomimetic method in order to improve the in vitro and in vivo response of electrospun polymeric meshes. While the presence of the coating did not lead to improvement in the in vitro response (measured as Alkaline Phosphatase amounts) of hMSCs, the implantation of constructs seeded with goat MSCs led to bone formation in a nude mice model suggesting that the presence of a calcium phosphate coating improved the in vivo bioactivity of the electrospun mesh. Based on these results, millimetre scale three dimensional scaffolds for possible use in load bearing constructs containing various physico-chemical cues were fabricated in chapter 3 . While the primary scaffold structure was fabricated using three dimensional fibre deposition (3DF), micrometre scale fibres were incorporated using electrospinning. Further functionality in terms of chemical cues was added by the same biomimetic coating process as described in chapter 2. The obtained results show that milli-, micro- and nanoscale features for improving cell response can be integrated into a single scaffold by combining different technologies and techniques. 
Composite scaffolds for bone regeneration were prepared by electrospinning (chapter 4) using a combination of collagen -I, hydroxyapatite (HA) and a polymer to include the major components on bone tissue in a scaffold. The outcome of the study suggests that the presence of HA and fully dissolved collagen is beneficial to the metabolic activity and gene expression of osteogenic markers. Furthermore, it also suggests that a change in the solvent system results in different macroscopic forms of collagen - fibres or aggregates and might influence the behaviour of hMSCs.

Two approaches to create large scale three dimensional composite scaffolds of a polymer and HA were assessed in chapter 5. Conventional three dimensional composites were prepared using composite granules of a polymer and HA using 3DF whereas assembled composites were prepared by inserting HA pillars into polymeric scaffolds fabricated by 3DF. The assembled composites appear to elicit a better response from hMSCs compared to the conventional composites while the conventional composites had a higher Young's modulus. Given the flexibility in modifying HA content that leads to tunable mechanical properties and cell behaviour of the assembled construct and the difficulties in processing conventional composites above certain HA content $(15 \%$ by weight in this case), the assembly approach provides a good solution for the fabrication of three dimensional composites for bone tissue engineering.

Part B (chapters 6 and 7) focuses on the use of surface topography as a tool for altering cell behaviour. In chapter 6 , electrospun fibre meshes were post-processed using oxygen plasma to create fibres with modified physico-chemical characteristics like higher roughness, increased oxygen content, increase in the fraction of polar groups and a reduction in contact angle suggesting a more hydrophilic surface. Higher protein adsorption and increased gene expression of osteogenic markers suggests that oxygen plasma treatment can at least be used as a tool to initiate osteogenic differentiation of hMSCs.

Chapter 7 is a proof of concept study that demonstrates an imprinting process for patterning electrospun fibre meshes at physiological temperatures. This process can be performed in short times (1-5 minutes) and can pattern fibres at a length scale close to the fibre diameter, 
which is rarely achieved. Patterns ranging from lines to closed geometric shapes like circles and triangles (in different tones) were imprinted to show the feasibility of imprinting various shapes and to suggest that such a process can possibly be used to transfer promising topographies from two dimensional screens on to three dimensional substrates.

This thesis demonstrates that combining various technologies and materials results in adding layers of functionality to a scaffold. This ultimately results in improved performance of cells seeded on these constructs making such scaffolds interesting candidates for bone tissue engineering applications. 


\section{SAMENVATTING}

Het doel van tissue engineering is het herstellen, onderhouden en verbeteren van de functie van beschadigd weefsel. In een klassieke tissue engineering opstelling, dient een driedimensionale poreuze matrix, ook wel "scaffold" (lett. "steiger") genoemd, ter ondersteuning en als drager van groeifactoren en/of cellen. Humane mesenchymale stromale cellen (hMSCs) kunnen differentiëren naar bot, kraakbeen en vetweefsel en zijn daarom een belangrijke bron van cellen voor tissue engineering van bot.

Hoofdstuk 1 is een inleiding in het concept en de toepassingen van tissue engineering. Verschillende benaderingen en technologieën die toegepast worden in tissue engineering zijn beschreven en de doelen van het proefschrift zijn gepresenteerd.

De focus van deel A (hoofdstukken 2-5) is het onderzoeken van verschillende methoden om calcium-fosfaten toe te voegen aan polymere scaffolds: het aanbrengen van calcium-fosfaat coatings aan de oppervlakte van een polymeer en het maken van calcium-fosfaat/polymeer- composieten en hybride, samengestelde structuren. In hoofdstuk 2 werd een calcium-fosfaat coating aangebracht via een biomimetische route, om in vitro en in vivo bioactiviteit van polymere vezels, geproduceerd door electrospinnen (ESP), te verbeteren. Hoewel geen effect van de coating was waargenomen op de hoeveelheid alkalische fosfatase geproduceerd door hMSCs, heeft subcutane implantatie van constructen bestaande uit gecoate ESP vezels en geit MSCs geresulteerd in botvorming. Dit in tegenstelling tot constructen zonder coating, wat suggereert dat calcium-fosfaat coatings de in vivo bioactiviteit van ESP vezels kunnen verbeteren. Op basis van deze resultaten zijn driedimensionale scaffolds op millimeter schaal, met diverse fysisch-chemische eigenschappen ontwikkeld wat beschreven is in hoofdstuk 3. Primaire scaffold structuren werden gefabriceerd middels de zogenaamde3D fibre deposition (3DF) techniek, terwijl ESP werd gebruikt om vezels op micrometer schaal in te bouwen in de scaffolds. De oppervlakte van polymere scaffolds werd verder gefunctionaliseerd met een calcium-fosfaat coating zoals beschreven in hoofdstuk 2 . In dit deel van het proefschrift is aangetoond dat milli-, micro- en nanometer schaal structuren gecombineerd kunnen worden in een scaffold door verschillende productiemethoden met elkaar te combineren om zo controle te krijgen over 
het gedrag van cellen op scaffolds.

Composiet scaffolds voor bot regeneratie werden geconstrueerd door middel van ESP (hoofdstuk 4) van een combinatie van collageen I, hydroxyapatiet (HA) en een polymeer om zo de belangrijkste componenten van natuurlijk bot na te bootsen in een scaffold. Resultaten van deze studie hebben aangetoond dat de aanwezigheid van HA en volledig opgeloste collageen I, metabolische activiteit en osteogene differentiatie van hMSCs positief beïnvloedt. Daarnaast is gedemonstreerd dat verschillen in oplossysteem voor collageen van invloed zijn op macroscopische kenmerken van collageen vezels en daarmee mogelijk ook op cel gedrag op de scaffolds.

Twee methoden om driedimensionale scaffolds bestaande uit een polymeer en HA te maken, zijn onderzocht in hoofdstuk 5. Klassieke composiet scaffolds werden gemaakt uit granulen van een polymeer en HA door middel van $3 \mathrm{DF}$. Samengestelde scaffolds werden gemaakt door het plaatsen van HA blokjes in de poriën van polymere scaffolds geproduceerd door 3DF. De samengestelde composieten hebben betere resultaten getoond dan conventionele composieten betreffende het gedrag van hMSCs, terwijl conventionele composieten een hoger elasticiteitsmodulus hadden. Het belangrijkste voordeel van samengestelde composieten boven conventionele composieten voor het maken van bot tissue engineering scaffolds is de mogelijkheid om de mechanische eigenschappen en de respons van de cel scaffolds te controleren, door de hoeveelheid HA te variëren. Dit is veel moeilijker in conventionele scaffolds, omdat boven 15 gewichtsprocent HA, 3DF niet meer probleemloos gebruikt kan worden om de scaffolds te bouwen.

De focus van deel B van het proefschrift (hoofdstukken 6 en 7) ligt op het gebruik van oppervlakte topografieën om gedrag van cellen te beïnvloeden. In hoofdstuk 6 werden polymere vezels gemaakt middels ESP behandeld met zuurstof plasma om zo de fysisch-chemische eigenschappen, zoals ruwheid van het oppervlak, de hoeveelheid zuurstof en de hoeveelheid polaire groepen, te verhogen en de hydrofiliciteit te verbeteren. Meer eiwit adsorptie en een hogere gen expressie van osteogene markers op de zo gemodificeerde oppervlakken heeft gesuggereerd dat zuurstof plasma behandeling gebruikt kan worden als een manier om osteogene differentiatie van hMSCs te initiëren.

Hoofdstuk 7 is een proof-of-concept studie waarmee een methode om de op- 
pervlakte van ESP vezels te voorzien van patronen bij fysiologische temperatuur is gedemonstreerd. Dit proces werd uitgevoerd gedurende een relatief korte tijd ( 1 tot 5 minuten) op de schaal van de grootte van een vezel diameter, wat tot nog toe niet eerder is gedaan. Patronen variërend van lijnen tot dichte geometrische vormen als cirkels en driehoeken werden succesvol aangebracht op ESP polymeer vezels. Dit proces is interessant omdat het de mogelijkheid biedt driedimensionale structuren te voorzien van gecontroleerde oppervlakte topografieën.

Dit proefschrift laat zien dat door technologieën en materialen te combineren, scaffolds gemaakt kunnen worden met verschillende niveaus van functionaliteit. Dit heeft als einddoel de bioactiviteit van cellen op scaffolds te verhogen. Deze benadering van combineren van materialen en technologieën in scaffold productie is daarom van groot belang in tissue engineering van bot. 
1

\section{General Introduction}

If I have seen further than others, it is by standing upon the shoulders of giants.

- Sir Issac Newton 
Jature's design of the human body is elegant and has evolved with time, tear, disease and accidents. Inbuilt mechanisms exist for repair and regeneration. The regeneration of Prometheus' liver in Greek mythology might be one of the earliest instances where organ regeneration was mentioned, although it is debatable if the ancient Greeks possessed knowledge of liver regeneration. While organs and tissues in the body have a certain potential to heal, this potential may not be sufficient at all times. In such cases, tissue and organ transplantation is a possible treatment option. Advances in medicine, science and technology have led to successful transplantation of several organs like heart [1], kidneys [2], lungs [3], liver [4] etc. and tissue like cornea [5], bone [6], skin [7] etc. However, there exists a long waiting list for patients requiring various organ transplants. The need for active donors was highlighted in the Dutch TV show "De Grote Donorshow" (The big donor show), which, even though was a hoax, triggered public consciousness and discussion on the topic [8]. As a result of donor shortage, there is an increasing need for alternatives to transplantation. "Tissue engineering", coined in 1987 [9], was suggested as one possible option to address the challenges of shortage of suitable donors in a world of increasingly ageing population. The following year, tissue engineering was defined as, "the application of principles and methods of engineering and life sciences toward fundamental understanding of structure-function relationships in normal and pathological function" [10]. An outline, scope and possibilities of tissue engineering were elucidated by Langer and Vacanti in their publication in Science in 1993 [11] wherein they further improved on the definition to state that, "Tissue engineering is an interdisciplinary field that applies the principles of engineering and the life sciences toward the development of biological substitutes that restore, maintain, or improve tissue function" [10]

Tissue engineering approaches for bone repair and regeneration are based on stimulating bone formation through the use of growth factors and/or cells in combination with a biomaterial scaffold. Bone morphogenetic proteins (BMP), for example, were discovered and defined as compounds present in demineralised bone matrix (DBM) that are sole inducers of de novo bone formation [12]. Owing to their osteoinductive potential, two BMP family members have found the way to the clinic, where they are used for enhancing non-unions of long bones in humans, spinal fusion, craniomaxillofacial disease and for periodontal and dental indications as reviewed here [13]. The ad- 
vances in recombinant DNA technology have also allowed for the availability of BMPs readily and in large quantities. In the cell based approach, cells are obtained from the patient, expanded on two dimensional surfaces like plates or flasks, seeded on a three dimensional support structure called scaffold and finally the cell-scaffold construct is implanted into the patient for repair and regeneration. The schematic (Figure 1) illustrates the general concept of cellbased tissue engineering. The current thesis focuses on the cell based tissue

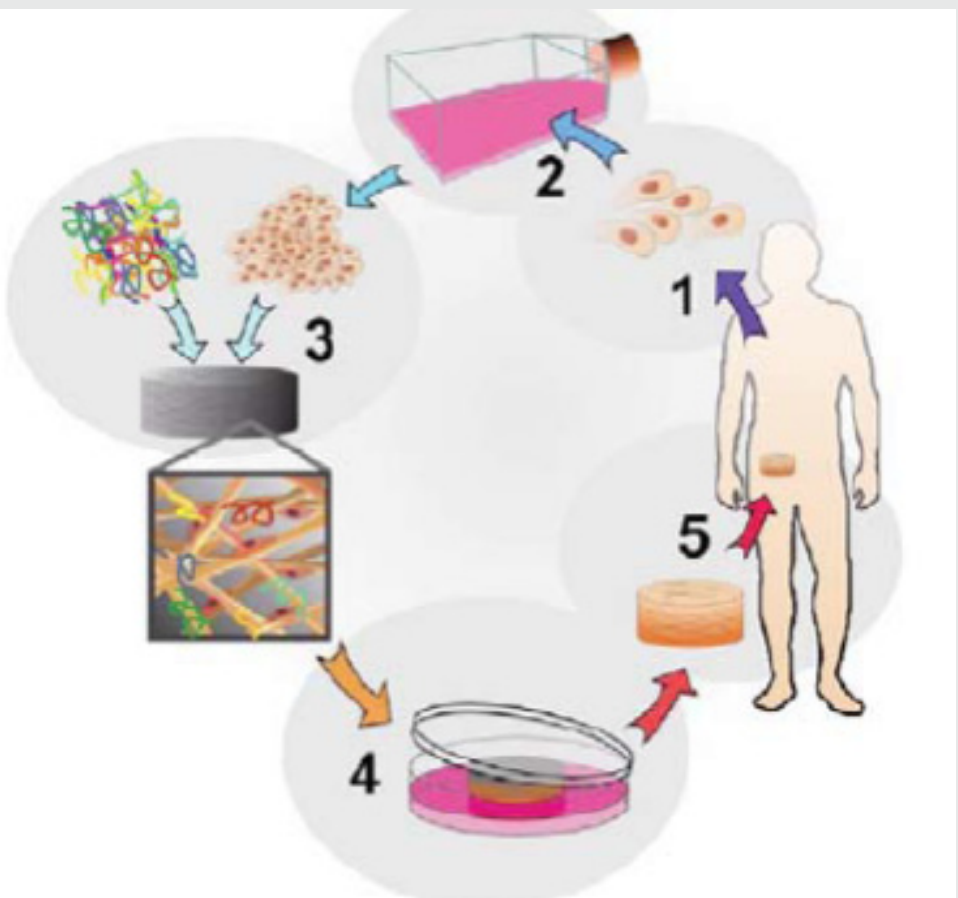

Figure 1: The cell based tissue engineering approach: (1) Patient biopsy to obtain autologous cells, (2) 2D culture and expansion in T-flasks, (3) Seeding of expanded donor cells on three dimensional scaffolds with the possible addition of growth factors, (4) Culture of cell seeded scaffolds to obtain tissue, (5) Implantation of tissue engineered construct in the patient. (Picture adapted from Julian H.S. George PhD thesis)

engineering approach for bone by combining scaffold fabrication technologies and different biomaterials to create suitable constructs. 


\section{NEED FOR BONE TISSUE ENGINEERING}

To realise the extent and prevalence of bone related diseases and 1 disorders, it is interesting to note that the World Health Organisation, on January 13, 2000 formally launched a Bone and Joint Decade for the period 2000-2010 [14]. Musculoskeletal conditions are the most common causes of severe long-term pain and physical disability and account for half of all chronic conditions in people above 50 years of age in developed countries. More than 43 million people in the United States of America have some form of arthritis and it is estimated that this number will increase to 60 million by 2020. The most prevalent musculoskeletal conditions for persons aged 18 and older are back or spine impairments which number 18.4 million [14]. In 1998, in the United States of America about 220,000 cases of spinal fusion requiring a bone graft were performed. Each year approximately 170,000 fractures do not heal and are diagnosed as "non-unions" thus requiring some form of bone substitute [15]. Hence, there is a very real need for alternatives to bone grafts and tissue engineering could be a viable option.

In this introductory chapter, the chemical and biological makeup of bone and the use of scaffolds for bone tissue engineering will briefly be discussed. Different materials, techniques and technologies that have been used for scaffold fabrication are outlined and explained. The central theme of the thesis is to combine or integrate materials and technologies to create improved scaffolds in terms of ability to provide physical and chemical cues to the in vivo environment.

\section{BONE}

$\mathrm{B}$ one is the main connective tissue in the human body with several important functions. Its primary function is to provide mechanical support to the body. It protects vital organs in the cranial and thoracic cavity, ligaments and muscles are attached to bones to provide movement and locomotion; it encloses the bone marrow from which red and white blood cells originate and it regulates the levels of calcium and phosphate in the blood [16]. Bone contains approximately $60 \%$ mineral, $30 \%$ organic matrix and $10 \%$ water by weight. The mineral phase mainly consists of carbonated calcium phosphate apatite while 
the organic matrix consists of about $90 \%$ collagen I and of about 10 $\%$ non collageneous proteins like osteocalcin, osteopontin, osteonectin and bone sialoprotein [17] and proteoglycans. The mineral phase contributes to the stiffness while the organic phase provides excellent tensile and loading strength.

On a structural level, two types of bones, namely cancellous (trabecular) and compact (cortical) bone exist. Cancellous bone is the most active type and is involved in growth, calcium homeostasis and haematopoiesis and supportive function where a compressive loading exists. Compact bone is more static and is mainly present in the shafts of long bones and peripheral lining of bones. Bone tissue is composed of four different cell types - osteoblasts, osteoclasts, bone lining cells and osteocytes. While the first three cell types are present on the bone surface, osteocytes reside inside lacunae surrounded by mineralised bone matrix. Osteoblasts are mature bone cells present on the surface and originate from osteoprogenitor cells. These cells are responsible for the production of bone matrix and regulation of mineralisation. Osteocytes are embedded in the mineral matrix and responsible for matrix maintenance. Bone lining cells are flat, elongated cells that cover the non-remodelling surface of the bone. These cells can be triggered to proliferate and differentiate into osteoprogenitor cells and also play a vital role in mineral homeostasis [18]. Osteoclasts are multinucleated cells that originate from the hematopoietic stem cells in the bone marrow and are responsible for bone resorption.

\section{BONE DEVELOPMENT AND REPAIR}

$\mathrm{B}$ one development occurs through two distinct mechanisms: intramembraneous and endochondral bone formation. Intramembraneous or direct bone formation is mediated by the inner periosteal osteogenic layer with bone synthesised without an intermediate cartilage phase through differentiation of mesenchymal stromal cells into preosteoblasts and finally osteoblasts. Endochondral bone formation involves the synthesis of bone on a mineralised cartilage matrix after epiphyseal and physeal cartilage have shaped and elongated the developing organ. Bone repair also follows one of the above mechanisms and the specific mechanism is, among others, determined by the biomechanical environment provided [19]. 
Soon after a fracture occurs, a number of events proceed to initiate the healing and repair process. The first event that occurs immediately is the activation of the coagulation cascade and the formation of a blood clot. Shortly afterwards, an acute inflammatory response resulting in tissue oedema and cytokine and growth factor release activates localised pluripotent osteoprogenitor cells. These cells produce a class of proteins known as bone morphogenetic proteins (BMPs), which are intimately bound to collagen. The BMPs along with other growth factors, cytokines, and hormones induce the migration of mesenchymal cells and their proliferation and differentiation into bone-forming cells. The first stage of collagen repair involving deposition and the formation of granulation tissue, leads to a new and temporary weak tissue. The second phase of collagen repair resulting in extracellular matrix remodelling, angiogenesis, and the reproduction of full-strength tissue completes the repair process. Both mechanisms of bone formation are used in the repair when appropriate. An initial stabilisation by cartilage that is replaced by bone as in endochondral bone formation occurs while simultaneously intramembraneous bone formation can be found depending on the local oxygen supply. Intramembraneous repair alone will be sufficient only when the fracture is stable with unchanged anatomy [20]. Thus, the healing of bone includes an initial rapid inflammatory response (minutes to hours), chemotaxis and mitosis (hours to days), production of extracellular matrix, remodelling of the injury site, and localised angiogenesis (days to weeks) [21]. When the self healing mechanism fails due to various reasons like magnitude of the defect, infection among others, bone grafts or bone graft substitutes are required.

From the perspective of bioactivity, an ideal bone graft material needs to have three essential characteristics - osteogenicity, osteoinductivity and osteoconductivity followed by the bonding between the host bone and the graft material, referred to as osteointegration [22]. Osteogenesis is the formation of new bone by determined osteoprogenitor cells [23]. Friedenstein [24] proposed one of the earliest definitions of osteoinduction as "the induction of undifferentiated inducible osteoprogenitor cells that are not yet committed to the osteogenic lineage to form osteoprogenitor cells". Urist, after his pioneering studies, defined it as "the mechanism of cellular differentiation towards bone of one tissue due to the physicochemical effect or contact with another tissue" [25]. 
Osteoconduction has been defined as the ability of a material/graft to allow ingrowth of vessels and osteoprogenitor cells from the recipient bed [26]. Davies defined osteoconduction as spreading of bone over the surface proceeded by ordered migration of differentiating osteogenic cells [27] Autologous bone exhibits all the above mentioned characteristics and does not elicit an immune response and is therefore considered the golden standard for bone repair and regeneration [26, 28-32]. Despite these advantages, autologous grafts may suffer from drawbacks associated with harvesting of the grafts such as chronic post- operative pain [26], infection [32] and donor site morbidity [28]. Other drawbacks include the risk of loss of the osteogenic potential due to cell death during transplantation and the limited availability in elderly or paediatric patients or patients with malignant diseases [22]. Although allogeneic and xenogeneic grafts are available, risk of immunogenic reaction $[25,33]$ exists. Methods to reduce such a reaction are available, but often lead to a decrease in biological performance [34-35]. In order to overcome shortage of natural grafts, several alternatives have been pursued. These include natural, biologically active components like DBM and collagen or synthetic substitutes based on metals (e.g. Ti, stainless steel), ceramics (calcium phosphate ceramics, alumina and glass ceramics), and polymers (e.g. poly (methyl methacrylate) - PMMA) and composites of the three. In addition to these approaches, tissue engineering strategies to further enhance repair and regeneration have also been developed using different carriers. As the focus of the thesis is on creating scaffolds for bone repair through a tissue engineering approach, the following section will focus on different synthetic substitutes which can also be used as scaffolds in a tissue engineering approach.

\section{MATERIALS USED AS SYNTHETIC BONE GRAFT SUBSTITUTES AND TISSUE ENGINEERING SCAFFOLDS}

$\mathrm{M}$ etals such as titanium and its alloys have been used to manufacture implants and prosthesis. They are biocompatible and have excellent mechanical properties enabling their use in load bearing applications [36-37]. However, stress shielding due to high stiffness of metals might be a contributing factor for detrimental resorptive bone 
remodelling [38]. In order to improve bonding of the implants to the surface and to adapt the mechanical properties of the implant to match the biological systems, various strategies have been pursued. Metallic implants have been coated with calcium phosphate coatings using different methods [39-42] and porous scaffolds based on Ti [43-44] have been fabricated for use in tissue engineered applications.

Calcium phosphate ceramics [45] like hydroxyapatite (HA) [46-47], tricalcium phosphate (TCP) [48-50] and biphasic calcium phosphate (BCP), consisting of HA and TCP [51], have been used as bone graft substitutes and as scaffold materials in bone tissue engineering constructs. Their similarity in chemical composition to bone mineral, biocompatibility and bioactivity [52] in terms of osteoconduction and osteointegration have made them suitable candidates as graft substitutes. These materials also undergo both chemical and biological degradation, which is suggested to be the origin of their bioactivity and are eventually replaced by bone. The degradation rates are determined by several factors related to both material and implantation site properties [53]. Among the various phases of calcium phosphates, HA and $\beta$-TCP are most widely used. HA degrades slowly while $\beta$-TCP has a much faster degradation rate [22]. BCP, obtained by a combination of HA and $\beta$-TCP has gained interest as its degradation rate can be tailored by altering the ratios of HA and $\beta$-TCP. Despite these advantages, most ceramics, while being hard, are brittle [53]. This makes it difficult to use them in load bearing sites.

While polymers like PMMA and high-density poly (ethylene) have been used as medical implants [52], biodegradable polymers like Polycaprolactone (PCL) [54-56], Poly lactic acid (PLA) [57], Poly(lactic-coglycolic acid) (PLGA) [58-59] and PolyActive ${ }^{\mathrm{TM}}$ (a block co-polymer of poly (ethylene oxide - terephthalate)/poly (butylene terephtalate) (PEOT/PBT)) [60-61] have been extensively used as bone tissue engineering scaffolds. Polymers offer the advantage of being able to promote cell growth and eventually degrade leaving no foreign substances inside the body, but in their native state usually lack sufficient mechanical properties and bioactivity.

As it is evident from the above discussion, each material type has advantages and disadvantages and a combination of two or more materials would result in a final product with much improved characteristics 
in terms of bioactivity and desired mechanical characteristics. As bone chemically consists of an organic (predominantly collagen) and inorganic (biological apatite) phase, a combination of natural or synthetic polymer and a calcium phosphate ceramic resulting in a composite or hybrid construct is a strategy that is currently used to create tissue engineering scaffolds for bone repair. The fabrication of polymerceramic composites or bi-phasic materials for bone tissue engineering can be achieved by combining different biomaterials and processing technologies. The following section discusses different approaches and techniques to create composite/biphasic scaffolds for bone tissue engineering.

\section{APPROACHES TO PREPARE POLYMER-CERAMIC SCAFFOLDS FOR BONE TISSUE ENGINEERING}

$\mathrm{W}$ hile different methods for preparing polymer-ceramic scaffolds exist, the following section will focus on three main approaches that have been used in the thesis - calcium phosphate coatings, rapid prototyping for fabricating three dimensional scaffolds and electrospinning.

\section{COATINGS}

Door mechanical properties of calcium phosphate ceramics make it Difficult to use them as standalone materials for load bearing applications [62]. In order to exploit the bioactivity of these ceramics, they were applied as coatings on metallic surfaces like titanium [39] which are often used as implants, e.g. in total hip arthroplasty or as dental implants. A classical way to coat orthopaedic implants made of titanium and its alloys is achieved by plasma spraying where HA powder is melted using ionised gas plasma and sprayed on to the substrate. Due to low residence times in the plasma zone, only a thin outer layer of the used powder gets into a molten state. When the molten particles reach the substrate to be coated, the differential cooling of the outer and inner layers leads to the formation of amorphous and crystalline phases. The amorphous phase is found more commonly at the substrate- coating interface and Gross et al. [63] stated that such heterogeneity in distribution of phase content is expected to negatively affect the clinical process of bone deposition, and therefore successful implant fixation. High temperatures during the process ensure that only thermally stable 
calcium phosphate phases can be produced and the incorporation of growth factors favourable to bone repair is not possible. The plasma sprayed HA coatings increased the success of hip arthroplasty [64-66] and improved the bonding between bone and the implants [67]. However, poor adhesion between the coating and the surface, delamination [68] and micro cracking [69] were observed.

Several other methods have also been used for coating substrates with calcium phosphate. These include sol-gel coatings [42], pulsed laser deposition [70], radio frequency sputtering [71] and electrochemical methods [72]. In the 1990s, Kokubo and co-workers developed mineralising solutions based on physiological fluids or simulated body fluids (SBF) [73-74]. These biomimetic coatings are formed at nearphysiological temperature and $\mathrm{pH}$ where apatite nucleation occurs on the surface of the substrate and grows over time. The biomimetic coating method offers several advantages like coating of temperature sensitive substrates like polymers [75], formation of phases other than HA, such as carbonated apatite and octacalcium phosphate (OCP) [76], deposition on porous and complex geometric shapes and the incorporation of growth factors [77] for stimulating bone regeneration. Barrere and colleagues modified the initial biomimetic coating process by using a supersaturated SBF to increase the speed of the coating process [78-79] to coat titanium based substrates. Recently, this coating process has also been used to coat other substrates like spider silk [80] and polymers[81]. Several other studies [82-84] have used a similar coating technique to coat polymeric scaffolds in different forms with calcium phosphate to form hybrid scaffolds that can be used for bone tissue engineering applications.

\section{SCAFFOLD FABRICATION TECHNOLOGIES}

$\mathrm{F}$ irst generation scaffolds used in tissue engineering applications were fabricated using conventional methods like solvent casting [85], gas foaming [86], freeze drying [87] and particulate leaching [60]. Although these techniques are very useful to fabricate scaffolds, they suffered some drawbacks. While it is possible to control pore size and shape by altering processing conditions, fabrication of fully interconnected scaffolds is a problem. Low interconnectivity leads to tortuous paths in the scaffolds, which influence nutrient availability and consequently, cell viability and distribution. In order to overcome 
these limitations, rapid prototyping (RP) techniques have been employed for fabricating scaffolds needed for various tissue engineering applications.

\section{A. RAPID PROTOTYPING}

T $n$ the past 25-30 years, several RP or Solid Freeform Fabrication (SFF) systems were developed and commercialised for manufacturing of prototypes for use in various industries like aerospace, automotive, consumer industry, electrical and electronic products and in biomedical applications [88]. As the name suggests, these techniques fabricate parts or prototypes without the use of moulds. Parts are built by adding materials layer by layer based on a computer program which is opposite to the usual practice of removing materials during conventional manufacturing processes. Additionally, RP can be used to fabricate controlled structures which can later be used as negative replicas or sacrificial moulds to fabricate scaffolds. In the last decade, RP technologies have been widely used to fabricate three dimensional scaffolds for a number of tissue engineering applications due to various advantages. RP technologies offer more control compared to conventional technologies and can reproducibly fabricate parts. Since the fabrication is performed layer by layer, it is also possible to modify properties of individual layers to obtain complex three dimensional scaffolds. The possibility to tune various aspects of scaffold properties like porosity, interconnectivity, mechanical strength and degradation makes RP a very powerful tool for scaffold production and allows the fabrication of customised scaffolds with properties that match a specific application [89-90]. RP technologies can also be integrated with standard medical imaging processes like CT or MRI to create customised implants for patients [91] (Figure 2).

Based on the type of technology used, RP systems can be classified into extrusion, laser and printing based systems. Figure 3 displays a schematic overview of the different types of RP systems [89]. Scaffolds for bone tissue engineering have been fabricated using all of the above mentioned systems. Among extrusion based systems, fused deposition modelling (FDM) is a very popular technique to fabricate scaffolds. FDM involves the extrusion of the material in a layered way to create scaffolds. While in the past it was only possible to use few non-resorbable polymeric materials (Acrylonitrile butadiene styrene, 
Polyamide etc), current FDM systems can process polymers like PCL,

(a)
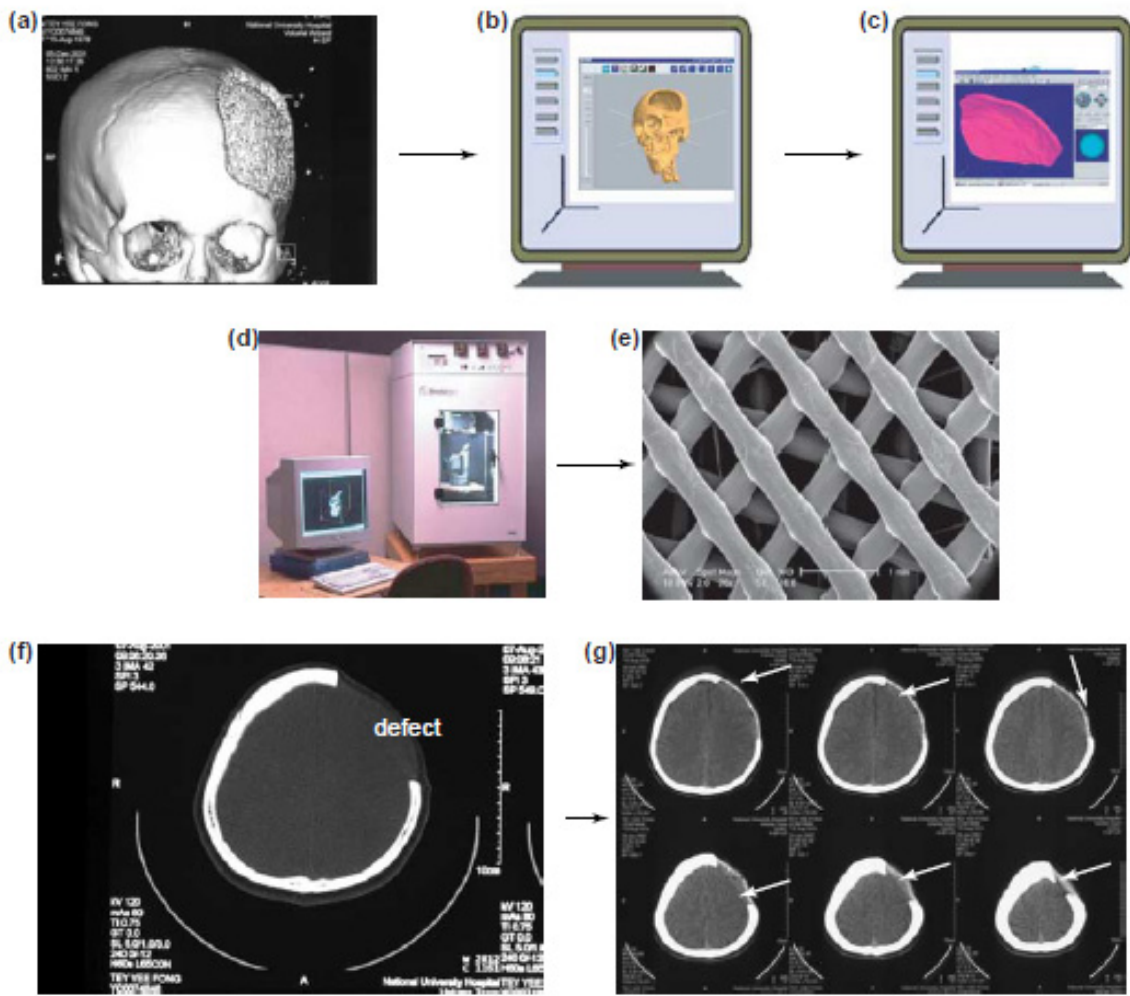

Figure 2: Tissue engineering of patient-specific bone grafts by combining medical imaging, computational modelling and rapid prototyping (RP). CT scan data of the patient's bone defect (a) are used to generate a computer-based $3 D$ model (b). This model is then imported into RP system software to be 'sliced' into thin horizontal layers, with the tool path specified for each layer (c). The 'sliced'data are used to instruct the RP machine (d) to build a scaffold (e) layer by layer, based on the actual shape of the computer model (c). $R P$ technology produces excellent templates for the treatment of intricate bone defects ( $a$ and f). Custom-made scaffold and cell constructs (g, see arrows) exactly follow the complex shaped 3D contour of the skull. Figure from Hutmacher et.al [91].

PLLA, PLGA that are widely used in biomedical applications. Extensive work in fabrication, characterisation and testing of 3D polymeric scaffolds from PCL and composites like PCL/TCP, PCL/HA for bone tissue engineering has been performed by Hutmacher and co-workers [92-98]. In our research group, 3D fibre deposition (3DF), a variant of FDM, has been used for the fabrication of scaffolds for bone and car- 
tilage tissue engineering. The 3DF process involves the extrusion of a molten polymer, hydrogel or a paste in the form of a fibre using a Computer Aided Manufacturing (CAM) robot. A layer by layer deposition is performed to obtain the final scaffold with tunable properties. Scaf-

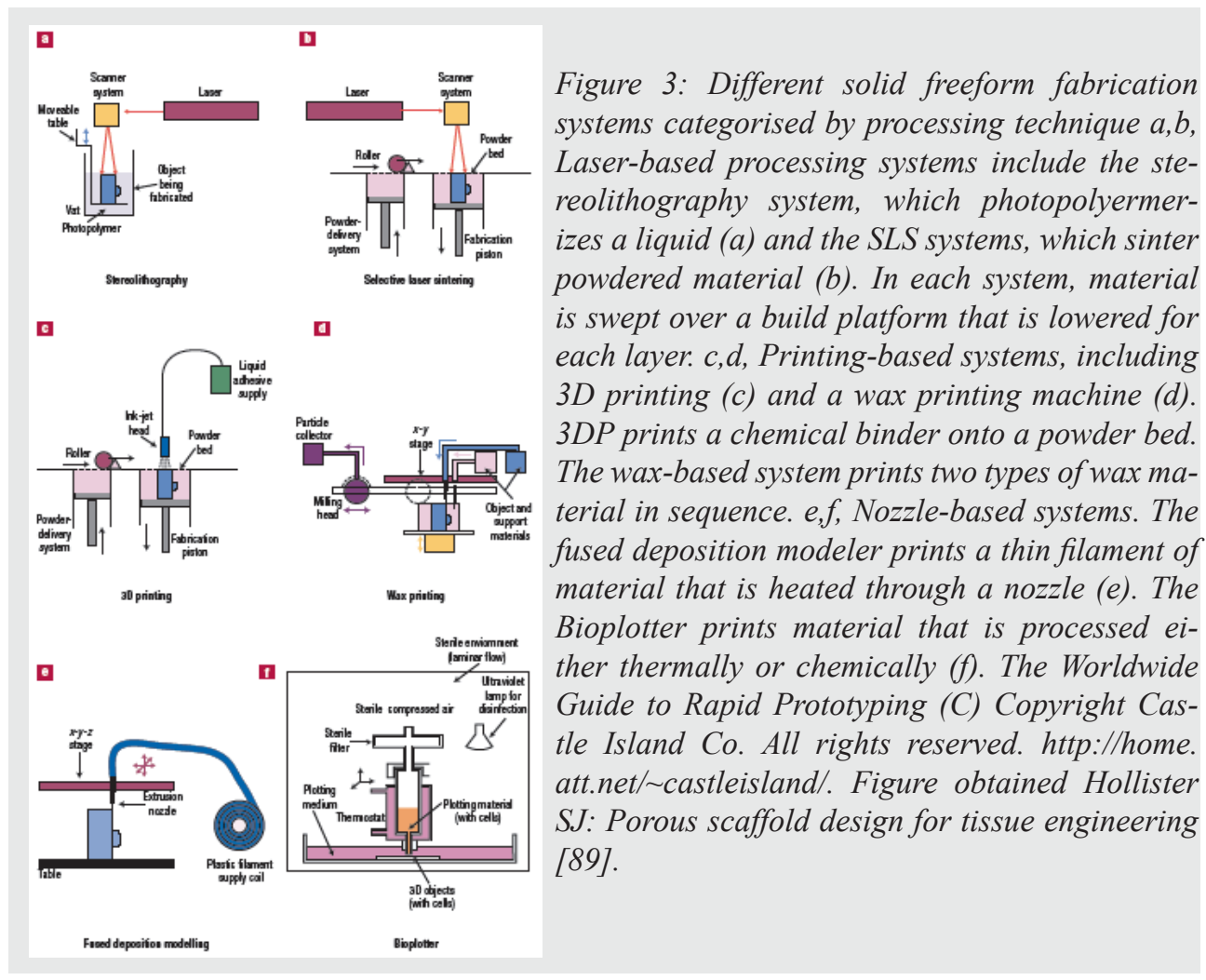

folds were fabricated from polymers [99-103] and titanium slurry [43, 104-105]. Anatomical scaffolds of trachea [106] were also fabricated from patient derived CT data sets. The use of RP technologies and the control it provides over parameters like pore size and shape enabled the creation of different scaffolds where the mechanical properties could be modulated to match that of a particular tissue to be repaired [100]. The advantages of extrusion based systems include the processing of all material types as well as hydrogels and cells, no trapping of unused materials inside the final construct and only temporary heating of raw materials at elevated temperatures which prevents negative effects of long term heating, such as thermal degradation [107-109]. 
Techniques based on lasers include stereolithography (SLA) and Selective Laser Sintering (SLS). In SLA, UV or visible light lasers are vector scanned on a bath that contains a photopolymerisable resin. The laser cures the resin at specific areas where it was illuminated and creates a solid layer that attaches to the support platform. This process is repeated layer by layer to create a three dimensional structure based on a CAD model. Excess resin is washed out and the sample maybe cured in a UV oven if needed. While SLA can achieve resolutions of around $20 \mu \mathrm{m}$ (other RP techniques are in the range of 50-200 $\mu \mathrm{m}$ ) and is relatively easy to remove support materials used during fabrication, the biggest limitation of SLA is the limited availability of photopolymerisable biomaterial resins with desired properties [107, 109]. Hence, SLA was primarily used for creating three dimensional models that improved the spatial understanding of the anatomy and physiology and assisted surgeons by reducing the time and risk involved in a surgery [110-111]. However in the last decade, biodegradable resins based on poly (propylene fumarate) (PPF) [112], trimethylene carbonate (TMC) and $\varepsilon$-caprolactone (CL) [113-115] and d, 1-lactide (DLLA) [116-117] have been prepared that have enabled the use of scaffolds fabricated by SLA in tissue engineering applications.

SLS works in a manner similar to SLA with the difference that a powder bed is sintered selectively using a $\mathrm{CO}_{2}$ laser. The interaction of the material with the laser causes an increase in the temperature of the material and sintering occurs at temperatures slightly higher than glass transition temperature which fuses the particles. Subsequent layers are fabricated on top of existing layers and new powder is deposited using a roller. Using SLS, polymers like PCL, PEEK have been combined with ceramics to create composite bioactive scaffolds for bone tissue engineering applications [118-122]. High accuracy, good mechanical strength and a broad choice of materials are some of the advantages of SLS while high processing temperatures, difficulty in removing entrapped materials and the inability to process hydrogels and cells are some drawbacks [107, 109].

3-D printing (3DP) [123] has the advantage of being able to fabricate three dimensional structures at ambient temperatures with the possibility of incorporating cells. Fresh powder is deposited on the bed on to which a binder solution is printed by an inkjet head. After a layer is 
complete, fresh powder is added and the process of binding and powder addition continues until the complete structure has been fabricated. Weak bonding between layers and the difficulty of removing entrapped materials that could potentially lead to the incorporation of the binder material in the final scaffold causing toxicity problems are some disadvantages of this method [108-109]. 3DP was used for fabricating ceramic moulds to cast materials needed for orthopaedic implants [124] and a combination of PLGA, PLA and TCP was used to fabricate scaffold constructs for repair of articular cartilage [125]. In order to overcome biocompatibility issues posed by using organic solvents such as chloroform as binders, calcium phosphate based ceramics have been directly fabricated into scaffolds for bone tissue engineering using biocompatible or water soluble polymeric binders that can be removed during sintering at high temperatures [126-128]. Another printing based technology used for scaffold fabrication is Organ printing. Miranov et al. defined organ printing as "a rapid prototyping computeraided 3D printing technology, based on using layer by layer deposition of cell and/or cell aggregates into a 3D gel with sequential maturation of the printed construct into perfused and vascularised living tissue or organ" [129]. The process of organ printing can be divided into three steps, namely pre-processing - dealing with the development of a CAD model for the organ, processing - the actual layer by layer printing of cells or aggregates into a three dimensional structure based on the design and post-processing - the perfusion of printed organs and their biomechanical conditioning to both direct and accelerate organ maturation. While the homogeneous distribution of cells and the creation of a three dimensional cellular construct are advantageous, the organ printing method has several limitations including the choice of scaffold materials that can be used. Most scaffold materials for TE need a strong solvent for dissolving and hence, printing has been restricted to hydrogels and thermo-reversible polymers which lack rigidity [130].

\section{B. ELECTROSPINNING}

A lthough RP technologies have improved in terms of resolution, it $A$ is still impossible to reproduce features in the few micrometres to submicron range. It is due to this need that electrospinning, a technique originally developed for the field of textiles and filtration of aerosols 
has become popular with biomedical researchers. Cooley [131] and Morton [132] independently patented the method of electrically dispersing fluids in 1902. In 1934, Formhals [133] patented the practical results of producing silk like threads using cellulose based polymer solutions in probably the first instance of producing polymeric threads using electrical fields. In the late 30's Petryanov-Sokolov [134] used electrostatic fields to produce aerosol filters and the term electrospinning was first introduced in publications in the 90s [135].

The principle of electrospinning is based on the phenomenon that when a sufficiently high voltage is applied to a liquid droplet, it gets charged and the electrostatic forces of repulsion counteract the surface tension. As the intensity of the electric field is increased, the hemispherical surface of the drop is stretched to form a conical shape known as Taylor cone [136]. Once the strength of the electric field overcomes the surface tension, a continuous stream of liquid jet is ejected from the Taylor cone. The charged nature of the jet enables the control of the
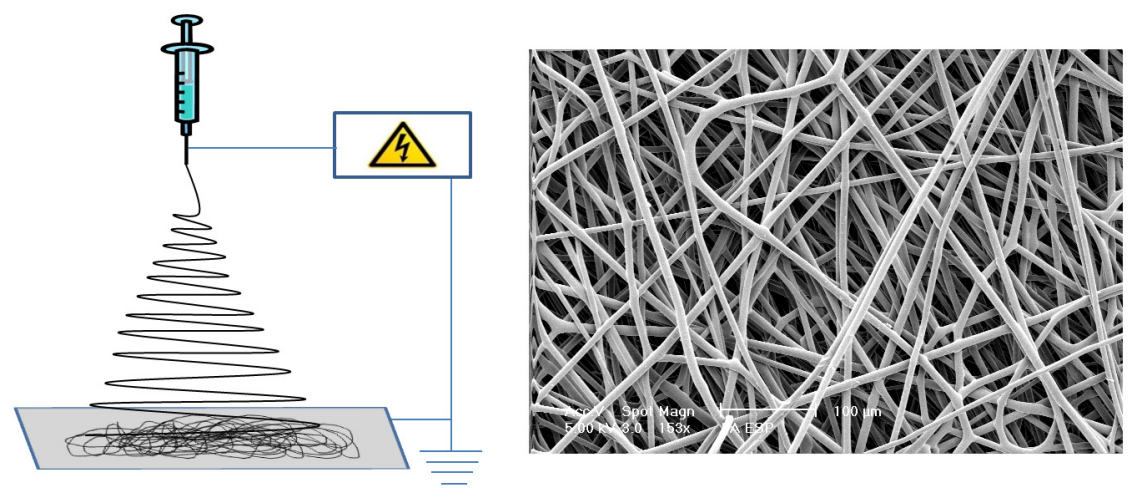

Figure 4: Schematic illustration of electrospinning technique. A polymer solution is dispensed through a nozzle connected to a high voltage supply. Fibres are obtained when the electrical forces overcome the surface tension of the droplet. The solvent evaporates as the fibre jet makes its way down to the grounded collector where dry fibres are collected. The image on the right depicts an electrospun mesh spun from a polymer solution (Scale bar $100 \mu \mathrm{m}$ ).

trajectory using an electric field. During its flight, the jet dries and is collected as non-woven fibres on a collector. A schematic depicting the process of electrospinning is shown in figure 4 . Due to the nature of 
the process, several factors affect the outcome of the spinning process. Doshi and Reneker [135] classified these properties as solution properties, controlled variables and ambient conditions. Solution properties include viscosity, conductivity, surface tension, molecular weight and dielectric constant whereas flow rate, applied electric field, air gap between needle and collector, collector geometry and design constitute the controlled variables. Temperature, humidity and air flow are the ambient parameters that influence the process.

The versatile nature of the process has enabled a range of different materials starting from synthetic polymers (PCL, PLLA, PolyActive ${ }^{\mathrm{TM}}$ ), natural polymers (collagen, gelatine, hyaluronate, silk etc.) and composite materials to be electrospun and these have found applications in engineering of various tissues like skin [137], cartilage [138], bone [54], blood vessels [139] and nerves [140] as well as in drug delivery [141]. The host of parameters that control the process also enables the modification of fibre texture [142-145] (smooth, rough, or porous) and orientation (random or aligned) [146-147].

Electrospun fibres have been used as scaffolds for bone TE in different ways. One of the first publications to investigate the use of electrospun meshes for bone TE was fabricated with PCL [54], a synthetic polymer. Later studies went on to use different polymers like PLA [57], polyhydroxybutyrate (PHB) or a polymeric blend like (poly-3-hydroxy butyrate-co-valerate (PHBV) [148]. In order to improve cell attachment and enhance the biological capability of the scaffolds, natural polymers like collagen [149], chitosan [150] and silk fibroin [151] were either used as stand-alone scaffolds or combined with polymers like PCL [152-153] and PLLA [154].

Bioactive inorganics have also been electrospun into fibres. Bioglass fibres with sub-micrometre diameter, for example, were obtained by mixing the glass with a polymeric binder [155]. Other studies have also reported the production of different inorganic fibres like HA [156158], fluoridated HA [157] and silica [159] fibres.

Also, studies on electrospinning of combinations of either synthetic or natural polymers with different calcium phosphate ceramics [160-165] have been performed. The challenge in such an approach is to find a compromise between processability of the material and the level of bioactivity that it possesses. 
Another strategy used for improving the bioactivity of electrospun scaffolds for different tissue engineering applications is surface modification. This is achieved by different methods like plasma treatment, attachment of functional groups and the conjugation of peptides [166$170]$. Based on the method used, biological phenomena like cell adhesion and differentiation are modulated due to the change in surface topography, wettability and chemistry. Treatment methods like plasma are simple and inexpensive and can be performed in most laboratories without the next for complex equipment.

Electrospinning offers advantages like ease of use, fabrication of fibres in the nanometre to micrometre range with different surfaces and alignment, mimicking of the fibrillar nature of the ECM and spinnability of various materials. While few recent studies [171-172] have fabricated three dimensional electrospun scaffolds by rolling sheets into cylindrical structures to achieve structures with compressive modulus in the range of trabecular bone (lower range $20 \mathrm{MPa}$ [173]), the use of electrospun scaffolds as standalone supports in compressive load bearing applications is a major limitation as insufficient mechanical support might lead to excessive deformation ultimately resulting in failure of nascent tissue formation [89] .

\section{AIMS OF THIS THESIS}

R ased on the above review, it can be inferred that scaffolds that combine bioactivity and satisfying mechanical properties have a greater chance of success in bone tissue engineering. Several techniques like RP and ESP can be employed to produce composite scaffolds but have their limitations as standalone technologies. The properties of the scaffolds could be improved by adding another "layer" of functionality by not only combining different materials, but also the technologies by which they are processed to create a scaffold. For example, a combination of RP and ESP techniques could result in a scaffold that is mechanically suitable for use in orthopaedic applications and still contains micro/nano scale functionality due to the presence of ECMlike fibres. Similarly, incorporating a calcium phosphate ceramic into a polymeric scaffold combines bioactivity of the former with mechanical suitability of the latter component. In order to exploit the power of various available technologies to a greater extent, combining or integrating them when fabricating a single scaffold is therefore an attractive approach. The broad aim of 
this thesis is to explore different technological platforms and combinations of materials to create improved scaffolds for bone tissue engineering. Different approaches undertaken are described in two parts in this thesis.

The central theme of part A is the incorporation of calcium phosphate ceramics and combination of 3DF and ESP techniques to create composite or hybrid materials. In chapter 2 , the feasibility of providing electrospun scaffolds with a calcium phosphate coating by an accelerated biomimetic process using supersaturated simulated body fluid is evaluated and the in vitro and in vivo effects of the coating are examined. The underlying hypothesis is that the presence of the coating would lead to improved biological activity of electrospun polymeric scaffolds in vitro and in vivo. Based on the groundwork in chapter 2 , three different techniques - rapid prototyping, electrospinning and biomimetic coatings were combined to obtain scaffolds that have macro, micro and nanoscale functionality in chapter 3 . The rapid prototyped part (macro) provides structural stability and can be used in load bearing defects while the electrospun component (micro) could act as a sieve to retain more cells in the construct and mimic the fibrillar nature of the ECM. Finally, the coating (nanocrystals) plays the role of the inorganic bone component and provides biological activity. The in vitro response of hMSCs on this multidimensional hybrid scaffolds was studied. In chapter 4 electrospinning was used to fabricate bioactive composite scaffolds consisting of hydroxyapatite and collagen with PolyActive ${ }^{\mathrm{TM}}$ as the base material. The method of collagen dissolution and the in vitro bioactivity using hMSCs culture were investigated.

Two different methods to fabricate three-dimensional polymer-HA composites are discussed in chapter 5. Composite filaments were extruded by blending the polymer and required amount of HA and then processed into 3-D scaffolds using 3DF and were termed conventional composites. Assembled composites, which were essentially hybrid structures, were fabricated by inserting HA pillars (prepared by pouring HA slurry on stereolithographic moulds and sintering) into polymeric scaffolds produced by 3DF. Mechanical properties, cell proliferation and gene expression of osteogenic markers were studied.

Part B describes surface modification as a strategy to alter cell behaviour. In chapter 6 , the effect of oxygen plasma on electrospun scaffolds to modify surface roughness and chemistry is analysed with the rationale that these changes could alter cell behaviour. The roughness, protein adsorption, cellular response and gene expression of hMSCs in these altered surfaces was studied. 
Chapter 7 presents a novel combination of electrospinning and nano-imprint lithography to pattern electrospun fibres at a single fibre level. A proof of concept study demonstrates the patterning of fibres at different scales (micro and nano), shapes (circles, triangles) and tones (pillars, pits). Patterns were characterised by image analysis and depth measurements. An initial in vitro experiment where hMSCs were seeded on to these patterns is also described.

Finally, a general discussion of the results obtained in chapters 2-7 along with future perspectives is provided in chapter 8 .

\section{REFERENCES}

1. Jordaan P. First heart transplant. AORN J 1968;8(3):43-45.

2. Merrill JP, Murray JE, Harrison JH, Guild WR. Successful homotransplantation of the human kidney between identical twins. J Am Med Assoc 1956;160(4):277-282.

3. Hardy JD. The first lung transplant in man (1963) and the first heart transplant in man (1964). Transplant Proc 1999;31(1-2):25-29.

4. Starzl TE, Marchioro TL, Vonkaulla KN, Hermann G, Brittain RS, Waddell WR. Homotransplantation of the Liver in Humans. Surg Gynecol Obstet 1963;117:659-676.

5. Moffatt SL, Cartwright VA, Stumpf TH. Centennial review of corneal transplantation. Clin Experiment Ophthalmol 2005;33(6):642-657.

6. Parrish FF. Treatment of bone tumors by total excision and replacement with massive autologous and homologous grafts. J Bone Joint Surg Am 1966;48(5):968-990.

7. Strumia MM, Hodge CC. Frozen Human Skin Grafts. Ann Surg 1945;121(6):860-865.

8. http://en.wikipedia.org/wiki/De_Grote_Donorshow. Online.

9. Heineken FG, Skalak R. Tissue Engineering - a Brief Overview. J Biomech Eng-T Asme 1991;113(2):111-112.

10. Fox RSaCF. Tissue Engineering. 1988: (Liss, New York,); 1988.

11. Langer R, Vacanti JP. Tissue engineering. Science 1993;260(5110):920926. 
12. Urist MR. Bone: formation by autoinduction. Science 1965;150(3698):893-899.

13. Kirker-Head CA. Potential applications and delivery strategies for bone morphogenetic proteins. Adv Drug Deliv Rev 2000;43(1):65-92.

14. Cambron J, King T. The Bone and Joint Decade: 2000 to 2010. J Manipulative Physiol Ther 2006;29(2):91-92.

15. . Online. Available from URL: http://www.btec.cmu.edu/tutorial/ need/need.htm

16. Fawcett D. A textbook of histology. Philadelphia: W.B. Saunders Company, 1986.

17. Roach HI. Why Does Bone-Matrix Contain Noncollagenous Proteins - the Possible Roles of Osteocalcin, Osteonectin, Osteopontin and Bone Sialoprotein in Bone Mineralization and Resorption. Cell Biol Int 1994;18(6):617628.

18. Miller SC, Saintgeorges L, Bowman BM, Jee WSS. Bone Lining Cells - Structure and Function. Scanning Microscopy 1989;3(3):953-961.

19. Shapiro F. Bone development and its relation to fracture repair. The role of mesenchymal osteoblasts and surface osteoblasts. Eur Cell Mater 2008;15:53-76.

20. Blitterswijk CA, Thomsen P. Tissue engineering: Academic, 2008.

21. Braddock M, Houston P, Campbell C, Ashcroft P. Born again bone: Tissue engineering for bone repair. News Physiol Sci 2001;16:208-213.

22. Giannoudis PV, Dinopoulos H, Tsiridis E. Bone substitutes: an update. Injury 2005;36 Suppl 3:S20-27.

23. Friedenstein AJ, Piatetzky S, II, Petrakova KV. Osteogenesis in transplants of bone marrow cells. J Embryol Exp Morphol 1966;16(3):381-390.

24. Friedenstein AY. Induction of bone tissue by transitional epithelium. Clin Orthop Relat Res 1968;59:21-37.

25. Urist MR, Silverman BF, Buring K, Dubuc FL, Rosenberg JM. The bone induction principle. Clin Orthop Relat Res 1967;53:243-283.

26. Damien CJ, Parsons JR. Bone graft and bone graft substitutes: a review of current technology and applications. J Appl Biomater 1991;2(3):187- 
208.

27. Davies JE. Mechanisms of endosseous integration. Int J Prosthodont 1998;11(5):391-401.

28. Brown KL, Cruess RL. Bone and cartilage transplantation in orthopaedic surgery. A review. J Bone Joint Surg Am 1982;64(2):270-279.

29. Coombes AG, Meikle MC. Resorbable synthetic polymers as replacements for bone graft. Clin Mater 1994;17(1):35-67.

30. de Boer HH. The history of bone grafts. Clin Orthop Relat Res 1988(226):292-298.

31. Yaszemski MJ, Payne RG, Hayes WC, Langer R, Mikos AG. Evolution of bone transplantation: molecular, cellular and tissue strategies to engineer human bone. Biomaterials 1996;17(2):175-185.

32. Lane JM, Tomin E, Bostrom MP. Biosynthetic bone grafting. Clin Orthop Relat Res 1999(367 Suppl):S107-117.

33. Brantigan JW, Cunningham BW, Warden K, McAfee PC, Steffee AD. Compression strength of donor bone for posterior lumbar interbody fusion. Spine (Phila Pa 1976) 1993;18(9):1213-1221.

34. Oklund SA, Prolo DJ, Gutierrez RV, King SE. Quantitative comparisons of healing in cranial fresh autografts, frozen autografts and processed autografts, and allografts in canine skull defects. Clin Orthop Relat Res 1986(205):269-291.

35. Anderson ML, Dhert WJ, de Bruijn JD, Dalmeijer RA, Leenders H, van Blitterswijk CA, et al. Critical size defect in the goat's os ilium. A model to evaluate bone grafts and substitutes. Clin Orthop Relat Res 1999(364):231239.

36. Agrawal CM. Reconstructing the human body using biomaterials. Jom-J Min Met Mat S 1998;50(1):31-35.

37. Tengvall P, Lundström I. Physico-chemical considerations of titanium as a biomaterial. Clinical Materials 1992;9(2):115-134.

38. Turner TM, Sumner DR, Urban RM, Rivero DP, Galante JO. A Comparative-Study of Porous Coatings in a Weight-Bearing Total Hip-Arthroplasty Model. J Bone Joint Surg Am 1986;68A(9):1396-1409.

39. de Groot K, Geesink R, Klein CP, Serekian P. Plasma sprayed coat- 
ings of hydroxylapatite. J Biomed Mater Res 1987;21(12):1375-1381.

40. Barrere F, Layrolle P, van Blitterswijk CA, de Groot K. Biomimetic coatings on titanium: a crystal growth study of octacalcium phosphate. Journal of Materials Science-Materials in Medicine 2001;12(6):529-534.

41. He DY, Sun XF, Zhao LD. Hydroxylapatite coatings by microplasma spraying. Journal of Inorganic Materials 2007;22(4):754-758.

42. Kim HW, Koh YH, Li LH, Lee S, Kim HE. Hydroxyapatite coating on titanium substrate with titania buffer layer processed by sol-gel method. Biomaterials 2004;25(13):2533-2538.

43. Li JP, de Wijn JR, Van Blitterswijk CA, de Groot K. Porous Ti6A14V scaffold directly fabricating by rapid prototyping: Preparation and in vitro experiment. Biomaterials 2006;27(8):1223-1235.

44. Chen YJ, Feng B, Zhu YP, Weng J, Wang JX, Lu X. Fabrication of porous titanium implants with biomechanical compatibility. Mater Lett 2009;63(30):2659-2661.

45. Yuan H, Fernandes H, Habibovic P, de Boer J, Barradas AM, de Ruiter A, et al. Osteoinductive ceramics as a synthetic alternative to autologous bone grafting. Proc Natl Acad Sci U S A 2010;107(31):13614-13619.

46. Deville S, Saiz E, Tomsia AP. Freeze casting of hydroxyapatite scaffolds for bone tissue engineering. Biomaterials 2006;27(32):5480-5489.

47. Yoshikawa H, Tamai N, Murase T, Myoui A. Interconnected porous hydroxyapatite ceramics for bone tissue engineering. J R Soc Interface 2009;6:S341-S348.

48. Niedhart C, Maus U, Redmann E, Siebert CH. In vivo testing of a new in situ setting beta-tricalcium phosphate cement for osseous reconstruction. Journal of Biomedical Materials Research 2001;55(4):530-537.

49. Fu S, Yoshikawa T, Hibino Y, Yamada Y, Niimi A, Honda M, et al. Osteogenic potential of porous beta-tricalcium phosphate (beta-TCP) combined with cultured bone. Tissue engineered bone using a biodegradable material as a scaffold. Key Eng Mat 2000;192-1:491-497.

50. Dong JA, Uemura T, Shirasaki Y, Tateishi T. Promotion of bone formation using highly pure porous beta-TCP combined with bone marrow-derived osteoprogenitor cells. Biomaterials 2002;23(23):4493-4502. 
51. Legeros RZ, Lin S, Rohanizadeh R, Mijares D, Legeros JP. Biphasic calcium phosphate bioceramics: preparation, properties and applications. Journal of Materials Science-Materials in Medicine 2003;14(3):201-209.

52. Costantino PD, Hiltzik D, Govindaraj S, Moche J. Bone healing and bone substitutes. Facial Plast Surg 2002;18(1):13-26.

53. Zimmermann G, Moghaddam A. Allograft bone matrix versus synthetic bone graft substitutes. Injury 2011;42:S16-S21.

54. Yoshimoto H, Shin YM, Terai H, Vacanti JP. A biodegradable nanofibre scaffold by electrospinning and its potential for bone tissue engineering. Biomaterials 2003;24(12):2077-2082.

55. Rohner D, Hutmacher DW, Cheng TK, Oberholzer M, Hammer B. In vivo efficacy of bone-marrow-coated polycaprolactone scaffolds for the reconstruction of orbital defects in the pig. Journal of Biomedical Materials Research Part B-Applied Biomaterials 2003;66B(2):574-580.

56. Williams JM, Adewunmi A, Schek RM, Flanagan CL, Krebsbach PH, Feinberg SE, et al. Bone tissue engineering using polycaprolactone scaffolds fabricated via selective laser sintering. Biomaterials 2005;26(23):4817-4827.

57. Badami AS, Kreke MR, Thompson MS, Riffle JS, Goldstein AS. Effect of fibre diameter on spreading, proliferation, and differentiation of osteoblastic cells on electrospun poly(lactic acid) substrates. Biomaterials 2006;27(4):596-606.

58. Thomson RC, Yaszemski MJ, Powers JM, Mikos AG. Fabrication of Biodegradable Polymer Scaffolds to Engineer Trabecular Bone. J Biomat Sci-Polym E 1995;7(1):23-38.

59. Ishaug SL, Payne RG, Yaszemski MJ, Aufdemorte TB, Bizios R, Mikos AG. Osteoblast migration on poly(alpha-hydroxy esters). Biotechnology and Bioengineering 1996;50(4):443-451.

60. Claase MB, Grijpma DW, Mendes SC, De Bruijn JD, Feijen J. Porous $\mathrm{PEOT/PBT} \mathrm{scaffolds} \mathrm{for} \mathrm{bone} \mathrm{tissue} \mathrm{engineering:} \mathrm{preparation,} \mathrm{charac-}$ terization, and in vitro bone marrow cell culturing. J Biomed Mater Res A 2003;64(2):291-300.

61. Radder AM, Leenders H, vanBlitterswijk CA. Application of porous $\mathrm{PEO} / \mathrm{PBT}$ copolymers for bone replacement. Journal of Biomedical Materials Research 1996;30(3):341-351. 
62. K. de Groot CdP, P.A.E. Sillevis Smith and A.A. Driessen. Mechanical failure of artificial teeth made of dense calcium hydroxyl-apetite. Science of Ceramics; 1981; 1981. p. 433-437.

63. Gross KA, Berndt CC, Herman H. Amorphous phase formation in plasma-sprayed hydroxyapatite coatings. J Biomed Mater Res 1998;39(3):407414.

64. Havelin LI, Engesaeter LB, Espehaug B, Furnes O, Lie SA, Vollset SE. The Norwegian Arthroplasty Register: 11 years and 73,000 arthroplasties. Acta Orthop Scand 2000;71(4):337-353.

65. Geesink RG. Hydroxyapatite-coated total hip prostheses. Two-year clinical and roentgenographic results of 100 cases. Clin Orthop Relat Res 1990(261):39-58.

66. Bauer TW, Geesink RC, Zimmerman R, McMahon JT. Hydroxyapatite-coated femoral stems. Histological analysis of components retrieved at autopsy. J Bone Joint Surg Am 1991;73(10):1439-1452.

67. Geesink RG, de Groot K, Klein CP. Bonding of bone to apatite-coated implants. J Bone Joint Surg Br 1988;70(1):17-22.

68. Willmann G. Coating of implants with hydroxyapatite material connections between bone and metal. Adv Eng Mater 1999;1(2):95-105.

69. Zhu X, Son DW, Ong JL, Kim K. Characterization of hydrothermally treated anodic oxides containing $\mathrm{Ca}$ and $\mathrm{P}$ on titanium. J Mater Sci Mater Med 2003;14(7):629-634.

70. Cleries L, Fernandez-Pradas JM, Morenza JL. Bone growth on and resorption of calcium phosphate coatings obtained by pulsed laser deposition. Journal of Biomedical Materials Research 2000;49(1):43-52.

71. Yang Y, Kim KH, Ong JL. A review on calcium phosphate coatings produced using a sputtering process--an alternative to plasma spraying. Biomaterials 2005;26(3):327-337.

72. Kumar M, Dasarathy H, Riley C. Electrodeposition of brushite coatings and their transformation to hydroxyapatite in aqueous solutions. J Biomed Mater Res 1999;45(4):302-310.

73. Abe Y, Kokubo T, Yamamuro T. Apatite Coating on Ceramics, Metals and Polymers Utilizing a Biological Process. Journal of Materials ScienceMaterials in Medicine 1990;1(4):233-238. 
74. Kokubo T, Kushitani H, Sakka S, Kitsugi T, Yamamuro T. Solutions able to reproduce in vivo surface-structure changes in bioactive glass-ceramic A-W. J Biomed Mater Res 1990;24(6):721-734.

75. Du C, Meijer GJ, van de Valk C, Haan RE, Bezemer JM, Hesseling $\mathrm{SC}$, et al. Bone growth in biomimetic apatite coated porous Polyactive $((\mathrm{R}))$ 1000PEGT70PBT30 implants. Biomaterials 2002;23(23):4649-4656.

76. Leeuwenburgh S, Layrolle P, Barrere F, de Bruijn J, Schoonman J, van Blitterswijk CA, et al. Osteoclastic resorption of biomimetic calcium phosphate coatings in vitro. J Biomed Mater Res 2001;56(2):208-215.

77. Liu YL, Hunziker EB, Layrolle P, De Bruijn JD, De Groot K. Bone morphogenetic protein 2 incorporated into biomimetic coatings retains its biological activity. Adv Exp Med Biol 2004;10(1-2):101-108.

78. Barrere F, van Blitterswijk CA, de Groot K, Layrolle P. Nucleation of biomimetic Ca-P coatings on Ti6Al4V from a SBF x 5 solution: influence of magnesium. Biomaterials 2002;23(10):2211-2220.

79. Barrere F, van Blitterswijk CA, de Groot K, Layrolle P. Influence of ionic strength and carbonate on the Ca-P coating formation from SBFx5 solution. Biomaterials 2002;23(9):1921-1930.

80. Yang L, Hedhammar M, Blom T, Leifer K, Johansson J, Habibovic $\mathrm{P}$, et al. Biomimetic calcium phosphate coatings on recombinant spider silk fibres. Biomed Mater 2010;5(4):045002.

81. Du C, Klasens P, Haan RE, Bezemer J, Cui FZ, de Groot K, et al. Biomimetic calcium phosphate coatings on Polyactive (R) 1000/70/30. Journal of Biomedical Materials Research 2002;59(3):535-546.

82. Yang F, Wolke JGC, Jansen JA. Biomimetic calcium phosphate coating on electrospun poly (epsilon-caprolactone) scaffolds for bone tissue engineering. Chem Eng J 2008;137(1):154-161.

83. Yuan XY, Mak AFT, Li JL. Formation of bone-like apatite on poly(Llactic acid) fibres by a biomimetic process. Journal of Biomedical Materials Research 2001;57(1):140-150.

84. Oliveira AL, Costa SA, Sousa RA, Reis RL. Nucleation and growth of biomimetic apatite layers on 3D plotted biodegradable polymeric scaffolds: Effect of static and dynamic coating conditions. Acta Biomaterialia 2009;5(5):1626-1638. 
85. Mikos AG, Sarakinos G, Leite SM, Vacanti JP, Langer R. Laminated 3-Dimensional Biodegradable Foams for Use in Tissue Engineering. Biomaterials 1993;14(5):323-330.

86. Mooney DJ, Baldwin DF, Suh NP, Vacanti JP, Langer R. Novel approach to fabricate porous sponges of poly(D,L-lactic-co-glycolic acid) without the use of organic solvents. Biomaterials 1996;17(14):1417-1422.

87. Schoof H, Apel J, Heschel I, Rau G. Control of pore structure and size in freeze-dried collagen sponges. J Biomed Mater Res 2001;58(4):352-357.

88. Chua CK, Leong KF, Lim CS. Rapid Prototyping: Principles and Applications: World Scientific, 2010.

89. Hollister SJ. Porous scaffold design for tissue engineering. Nat Mater 2005;4(7):518-524.

90. Lin CY, Kikuchi N, Hollister SJ. A novel method for biomaterial scaffold internal architecture design to match bone elastic properties with desired porosity. J Biomech 2004;37(5):623-636.

91. Hutmacher DW, Sittinger M, Risbud MV. Scaffold-based tissue engineering: rationale for computer-aided design and solid free-form fabrication systems. Trends in Biotechnology 2004;22(7):354-362.

92. Hutmacher DW, Schantz T, Zein I, Ng KW, Teoh SH, Tan KC. Mechanical properties and cell cultural response of polycaprolactone scaffolds designed and fabricated via fused deposition modeling. Journal of Biomedical Materials Research 2001;55(2):203-216.

93. Lam CXF, Hutmacher DW, Schantz JT, Woodruff MA, Teoh SH. Evaluation of polycaprolactone scaffold degradation for 6 months in vitro and in vivo. Journal of Biomedical Materials Research Part A 2009;90A(3):906919.

94. Lam CXF, Teoh SH, Hutmacher DW. Comparison of the degradation of polycaprolactone and polycaprolactone-(beta-tricalcium phosphate) scaffolds in alkaline medium. Polym Int 2007;56(6):718-728.

95. Schantz JT, Brandwood A, Hutmacher DW, Khor HL, Bittner K. Osteogenic differentiation of mesenchymal progenitor cells in computer designed fibrin-polymer-ceramic scaffolds manufactured by fused deposition modeling. Journal of Materials Science-Materials in Medicine 2005;16(9):807-819.

96. Yefang Z, Hutmacher DW, Varawan SL, Meng LT. Comparison of 
Human alveolar osteoblasts cultured on polymer-ceramic composite scaffolds and tissue culture plates. International Journal of Oral and Maxillofacial Surgery 2007;36(2):137-145.

97. Zhou YF, Hutmacher DW, Varawan SL, Lim TM. In vitro bone engineering based on polycaprolactone and polycaprolactone-tricalcium phosphate composites. Polym Int 2007;56(3):333-342.

98. Endres M, Hutmacher DW, Salgado AJ, Kaps C, Ringe J, Reis RL, et al. Osteogenic induction of human bone marrow-derived mesenchymal progenitor cells in novel synthetic polymer-hydrogel matrices. Adv Exp Med Biol 2003;9(4):689-702.

99. Moroni L, Hamann D, Paoluzzi L, Pieper J, de Wijn JR, van Blitterswijk CA. Regenerating articular tissue by converging technologies. PLoS One 2008;3(8):e3032.

100. Moroni L, Poort G, Van Keulen F, de Wijn JR, van Blitterswijk CA. Dynamic mechanical properties of 3D fibre-deposited PEOT/PBT scaffolds: An experimental and numerical analysis. J Biomed Mater Res A 2006(78):605614.

101. Moroni L, Schotel R, Hamann D, de Wijn JR, van Blitterswijk CA. 3D fibre-deposited electrospun integrated scaffolds enhance cartilage tissue formation. Advanced Functional Materials 2008;18(1):53-60.

102. Woodfield TB, Van Blitterswijk CA, De Wijn J, Sims TJ, Hollander AP, Riesle J. Polymer scaffolds fabricated with pore-size gradients as a model for studying the zonal organization within tissue-engineered cartilage constructs. Tissue Eng 2005;11(9-10):1297-1311.

103. Woodfield TBF, Malda J, de Wijn J, Peters F, Riesle J, van Blitterswijk CA. Design of porous scaffolds for cartilage tissue engineering using a threedimensional fibre-deposition technique. Biomaterials 2004;25(18):41494161.

104. Li JP, de Wijn JR, van Blitterswijk CA, de Groot K. Porous Ti6Al4V scaffolds directly fabricated by 3D fibre deposition technique: effect of nozzle diameter. J Mater Sci Mater Med 2005;16(12):1159-1163.

105. Li JP, de Wijn JR, van Blitterswijk CA, de Groot K. The effect of scaffold architecture on properties of direct 3D fibre deposition of porous Ti6Al4V for orthopedic implants. J Biomed Mater Res A 2010;92(1):33-42. 
106. Moroni L, Curti M, Welti M, Korom S, Weder W, De Wijn JR, et al. Anatomical 3D fibre-deposited scaffolds for tissue engineering: Designing a neotrachea. Adv Exp Med Biol 2007;13(10):2483-2493.

107. Melchels FP, Feijen J, Grijpma DW. A review on stereolithography and its applications in biomedical engineering. Biomaterials 2010;31(24):61216130 .

108. Peltola SM, Melchels FPW, Grijpma DW, Kellomaki M. A review of rapid prototyping techniques for tissue engineering purposes. Ann Med 2008;40(4):268-280.

109. Yang SF, Leong KF, Du ZH, Chua CK. The design of scaffolds for use in tissue engineering. Part II. Rapid prototyping techniques. Adv Exp Med Biol 2002;8(1):1-11.

110. Binder TM, Moertl D, Mundigler G, Rehak G, Franke M, Delle-Karth $\mathrm{G}$, et al. Stereolithographic biomodeling to create tangible hard copies of cardiac structures from echocardiographic data: in vitro and in vivo validation. $\mathrm{J}$ Am Coll Cardiol 2000;35(1):230-237.

111. Sarment DP, Al-Shammari K, Kazor CE. Stereolithographic surgical templates for placement of dental implants in complex cases. Int J Periodontics Restorative Dent 2003;23(3):287-295.

112. Cooke MN, Fisher JP, Dean D, Rimnac C, Mikos AG. Use of stereolithography to manufacture critical-sized 3D biodegradable scaffolds for bone ingrowth. Journal of Biomedical Materials Research Part B-Applied Biomaterials 2003;64B(2):65-69.

113. Lee SJ, Kang HW, Park JK, Rhie JW, Hahn SK, Cho DW. Application of microstereolithography in the development of three-dimensional cartilage regeneration scaffolds. Biomedical Microdevices 2008;10(2):233-241.

114. Matsuda T, Mizutani M. Liquid acrylate-endcapped biodegradable poly(epsilon-caprolactone-co-trimethylene carbonate). II. Computer-aided stereolithographic microarchitectural surface photoconstructs. Journal of Biomedical Materials Research 2002;62(3):395-403.

115. Matsuda T, Mizutani M, Arnold SC. Molecular design of photocurable liquid biodegradable copolymers. 1. Synthesis and photocuring characteristics. Macromolecules 2000;33(3):795-800.

116. Jansen J, Melchels FPW, Grijpma DW, Feijen J. Fumaric Acid Mono- 
ethyl Ester-Functionalized Poly(D,L-lactide)/N-vinyl-2-pyrrolidone Resins for the Preparation of Tissue Engineering Scaffolds by Stereolithography. Biomacromolecules 2009;10(2):214-220.

117. Melchels FP, Feijen J, Grijpma DW. A poly(D,L-lactide) resin for the preparation of tissue engineering scaffolds by stereolithography. Biomaterials 2009;30(23-24):3801-3809.

118. Antonov EN, Bagratashvili VN, Whitaker MJ, Barry JJ, Shakesheff KM, Konovalov AN, et al. Three-Dimensional Bioactive and Biodegradable Scaffolds Fabricated by Surface-Selective Laser Sintering. Adv Mater Deerfield 2004;17(3):327-330.

119. Duan B, Wang M, Zhou WY, Cheung WL, Li ZY, Lu WW. Threedimensional nanocomposite scaffolds fabricated via selective laser sintering for bone tissue engineering. Acta Biomater 2010;6(12):4495-4505.

120. Tan KH, Chua CK, Leong KF, Cheah CM, Cheang P, Abu Bakar MS, et al. Scaffold development using selective laser sintering of polyetheretherketone-hydroxyapatite biocomposite blends. Biomaterials 2003;24(18):31153123 .

121. von Wilmowsky C, Vairaktaris E, Pohle D, Rechtenwald T, Lutz R, Munstedt H, et al. Effects of bioactive glass and beta-TCP containing threedimensional laser sintered polyetheretherketone composites on osteoblasts in vitro. Journal of Biomedical Materials Research Part A 2008;87A(4):896902.

122. Williams JM, Adewunmi A, Schek RM, Flanagan CL, Krebsbach PH, Feinberg SE, et al. Bone tissue engineering using polycaprolactone scaffolds fabricated via selective laser sintering. Biomaterials 2005;26(23):4817-4827.

123. Sachs E.M. HJS, Cima M.J., Williams P.A. Three-dimensional printing techniques

issued/filed dates: April 20, 1993/Dec. 8, 1989.

124. Curodeau A, Sachs E, Caldarise S. Design and fabrication of cast orthopedic implants with freeform surface textures from 3-D printed ceramic shell. Journal of Biomedical Materials Research 2000;53(5):525-535.

125. Sherwood JK, Riley SL, Palazzolo R, Brown SC, Monkhouse DC, Coates $\mathrm{M}$, et al. A three-dimensional osteochondral composite scaffold for articular cartilage repair. Biomaterials 2002;23(24):4739-4751. 
126. Khalyfa A, Vogt S, Weisser J, Grimm G, Rechtenbach A, Meyer W, et al. Development of a new calcium phosphate powder-binder system for the 3D printing of patient specific implants. Journal of Materials ScienceMaterials in Medicine 2007;18(5):909-916.

127. Leukers B, Gulkan H, Irsen SH, Milz S, Tille C, Schieker M, et al. Hydroxyapatite scaffolds for bone tissue engineering made by $3 \mathrm{D}$ printing. Journal of Materials Science-Materials in Medicine 2005;16(12):1121-1124.

128. Seitz H, Rieder W, Irsen S, Leukers B, Tille C. Three-dimensional printing of porous ceramic scaffolds for bone tissue engineering. Journal of Biomedical Materials Research Part B-Applied Biomaterials 2005;74B(2):782788 .

129. Mironov V, Boland T, Trusk T, Forgacs G, Markwald RR. Organ printing: computer-aided jet-based 3D tissue engineering. Trends Biotechnol 2003;21(4):157-161.

130. Ringeisen BR, Othon CM, Barron JA, Young D, Spargo BJ. Jet-based methods to print living cells. Biotechnol J 2006;1(9):930-948.

131. COOLEY JF. APPARATUS FOR ELECTRICALLY DISPERSING FLUIDS. USA Patent No. 692,631, 1902.

132. MORTON WJ. METHOD OF DISPERSING FLUIDS Patent No. 703,691, 1902.

133. Formhals A. PROCESS AND APPARATUS FOR PREPARING ARTIFICIAL THREADS Patent No. 1,975,504, 1934.

134. Lushnikov A. Igor' Vasilievich Petryanov-Sokolov (1907-1996) Obituary. J Aerosol Sci 1997;28(4):545-546.

135. Doshi J, Reneker DH. Electrospinning Process and Applications of Electrospun Fibres. Journal of Electrostatics 1995;35(2-3):151-160.

136. Taylor G. Electrically Driven Jets. Proc R Soc Lon Ser-A 1969;313(1515):453-475.

137. Laurencin CT, Kumbar SG, Nukavarapu SP, James R, Nair LS. Electrospun poly(lactic acid-co-glycolic acid) scaffolds for skin tissue engineering. Biomaterials 2008;29(30):4100-4107.

138. Li WJ, Tuli R, Okafor C, Derfoul A, Danielson KG, Hall DJ, et al. A three-dimensional nanofibrous scaffold for cartilage tissue engineering using 
human mesenchymal stem cells. Biomaterials 2005;26(6):599-609.

139. Buttafoco L, Kolkman NG, Poot AA, Dijkstra PJ, Vermes I, Feijen J. Electrospinning collagen and elastin for tissue engineering small diameter blood vessels. Journal of Controlled Release 2005;101(1-3):322-324.

140. Yang F, Murugan R, Wang S, Ramakrishna S. Electrospinning of nano/micro scale poly(L-lactic acid) aligned fibres and their potential in neural tissue engineering. Biomaterials 2005;26(15):2603-2610.

141. Ranganath SH, Wang CH. Biodegradable microfibre implants delivering paclitaxel for post-surgical chemotherapy against malignant glioma. Biomaterials 2008;29(20):2996-3003.

142. Casper CL, Stephens JS, Tassi NG, Chase DB, Rabolt JF. Controlling surface morphology of electrospun polystyrene fibres: Effect of humidity and molecular weight in the electrospinning process. Macromolecules 2004;37(2):573-578.

143. De Vrieze S, Van Camp T, Nelvig A, Hagstrom B, Westbroek P, De Clerck K. The effect of temperature and humidity on electrospinning. J Mater Sci 2009;44(5):1357-1362.

144. Deitzel JM, Kleinmeyer J, Harris D, Tan NCB. The effect of processing variables on the morphology of electrospun nanofibres and textiles. Polymer 2001;42(1):261-272.

145. Moroni L, Licht R, de Boer J, de Wijn JR, van Blitterswijk CA. Fibre diameter and texture of electrospun PEOT/PBT scaffolds influence human mesenchymal stem cell proliferation and morphology, and the release of incorporated compounds. Biomaterials 2006;27(28):4911-4922.

146. Aviss KJ, Gough JE, Downes S. Aligned Electrospun Polymer Fibres for Skeletal Muscle Regeneration. Eur Cells Mater 2010;19:193-204.

147. Teo WE, Ramakrishna S. Electrospun fibre bundle made of aligned nanofibres over two fixed points. Nanotechnology 2005;16(9):1878-1884.

148. Sombatmankhong K, Sanchavanakit N, Pavasant P, Supaphol P. Bone scaffolds from electrospun fibre mats of poly (3-hydroxybutyrate), poly(3-hydroxybutyrate-co-3-hydroxyvalerate) and their blend. Polymer 2007;48(5):1419-1427.

149. Shih YR, Chen CN, Tsai SW, Wang YJ, Lee OK. Growth of mesenchymal stem cells on electrospun type I collagen nanofibres. Stem Cells 
2006;24(11):2391-2397.

150. Shin SY, Park HN, Kim KH, Lee MH, Choi YS, Park YJ, et al. Biological evaluation of chitosan nanofibre membrane for guided bone regeneration. J Periodontol 2005;76(10):1778-1784.

151. Meechaisue C, Wutticharoenmongkol P, Waraput R, Huangjing T, Ketbumrung N, Pavasant P, et al. Preparation of electrospun silk fibroin fibre mats as bone scaffolds: a preliminary study. Biomed Mater 2007;2(3):181188.

152. Ekaputra AK, Zhou Y, Cool SM, Hutmacher DW. Composite electrospun scaffolds for engineering tubular bone grafts. Tissue Eng Part A 2009;15(12):3779-3788.

153. Zhang YZ, Ouyang HW, Lim CT, Ramakrishna S, Huang ZM. Electrospinning of gelatin fibres and gelatin/PCL composite fibrous scaffolds. Journal of Biomedical Materials Research Part B-Applied Biomaterials 2005;72B(1):156-165.

154. Kim HW, Yu HS, Lee HH. Nanofibrous matrices of poly(lactic acid) and gelatin polymeric blends for the improvement of cellular responses. J Biomed Mater Res A 2008;87(1):25-32.

155. Kim HW, Kim HE, Knowles JC. Production and potential of bioactive glass nanofibres as a next-generation biomaterial. Advanced Functional Materials 2006;16(12):1529-1535.

156. Wu YQ, Hench LL, Du J, Choy KL, Guo JK. Preparation of hydroxyapatite fibres by electrospinning technique. J Am Ceram Soc 2004;87(10):19881991.

157. Kim HW, Kim HE. Nanofibre generation of hydroxyapatite and fluorhydroxyapatite bioceramics. Journal of Biomedical Materials Research Part B-Applied Biomaterials 2006;77B(2):323-328.

158. Dai XS, Shivkumar S. Electrospinning of PVA-calcium phosphate sol precursors for the production of fibrous hydroxyapatite. J Am Ceram Soc 2007;90(5):1412-1419.

159. Sakai S, Yamada Y, Yamaguchi T, Kawakami K. Prospective use of electrospun ultra-fine silicate fibres for bone tissue engineering. Biotechnol J 2006;1(9):958-962 .

160. Jose MV, Thomas V, Xu Y, Bellis S, Nyairo E, Dean D. Aligned bio- 
active multi-component nanofibrous nanocomposite scaffolds for bone tissue engineering. Macromol Biosci 2010;10(4):433-444.

161. Kim HW, Lee HH, Knowles JC. Electrospinning biomedical nanocomposite fibres of hydroxyapaite/poly(lactic acid) for bone regeneration. Journal of Biomedical Materials Research Part A 2006;79A(3):643-649.

162. Song JH, Kim HE, Kim HW. Electrospun fibrous web of collagenapatite precipitated nanocomposite for bone regeneration. J Mater Sci Mater Med 2008;19(8):2925-2932.

163. Thomas V, Dean DR, Jose MV, Mathew B, Chowdhury S, Vohra YK. Nanostructured biocomposite scaffolds based on collagen coelectrospun with nanohydroxyapatite. Biomacromolecules 2007;8(2):631-637.

164. Venugopal JR, Low S, Choon AT, Kumar AB, Ramakrishna S. Nanobioengineered electrospun composite nanofibres and osteoblasts for bone regeneration. Artif Organs 2008;32(5):388-397.

165. Yang F, Both SK, Yang X, Walboomers XF, Jansen JA. Development of an electrospun nano-apatite/PCL composite membrane for GTR/GBR application. Acta Biomater 2009;5(9):3295-3304.

166. Xu ZX, Li T, Zhong ZM, Zha DS, Wu SH, Liu Q, et al. Amide-Linkage Formed Between Ammonia Plasma Treated Poly(D,L-lactide acid) Scaffolds and Bio-Peptides: Enhancement of Cell Adhesion and Osteogenic Differentiation In Vitro. Biopolymers 2011;95(10):682-694.

167. Prabhakaran MP, Venugopal J, Chan CK, Ramakrishna S. Surface modified electrospun nanofibrous scaffolds for nerve tissue engineering. Nanotechnology 2008;19(45):-.

168. Martins A, Pinho ED, Faria S, Pashkuleva I, Marques AP, Reis RL, et al. Surface modification of electrospun polycaprolactone nanofibre meshes by plasma treatment to enhance biological performance. Small 2009;5(10):11951206.

169. Chen JP, Su CH. Surface modification of electrospun PLLA nanofibres by plasma treatment and cationized gelatin immobilization for cartilage tissue engineering. Acta Biomaterialia 2011;7(1):234-243.

170. Park K, Ju YM, Son JS, Ahn KD, Han DK. Surface modification of biodegradable electrospun nanofibre scaffolds and their interaction with fibroblasts. J Biomat Sci-Polym E 2007;18(4):369-382. 
171. Deng M, Kumbar SG, Nair LS, Weikel AL, Allcock HR, Laurencin CT. Biomimetic Structures: Biological Implications of Dipeptide-Substituted Polyphosphazene-Polyester Blend Nanofibre Matrices for Load-Bearing Bone Regeneration. Advanced Functional Materials 2011;21(14):2641-2651.

172. Wright LD, Young RT, Andric T, Freeman JW. Fabrication and mechanical characterization of 3D electrospun scaffolds for tissue engineering. Biomed Mater 2010;5(5).

173. Athanasiou KA, Zhu CF, Lanctot DR, Agrawal CM, Wang X. Fundamentals of biomechanics in tissue engineering of bone. Adv Exp Med Biol 2000;6(4):361-381. 


\section{PART A}

\section{Incorporation of calcium-phosphates in polymeric scaffolds: Coatings, Composites and Assembly}

Look deep into nature, and then you will understand everything better.

- Albert Einstein 


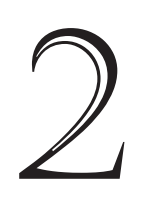

\section{Calcium phosphate coated electrospun fibre matrices as scaffolds for bone tissue engineering}

Anandkumar Nandakumar, Liang Yang, Pamela Habibovic, Clemens van Blitterswijk

Department of Tissue Regeneration, MIRA Institute for Biomedical Technology and Technical Medicine, University of Twente, The Netherlands 


\section{ABSTRACT}

Electrospun polymeric scaffolds are used for various tissue engineering applications. In this study, we applied a biomimetic coating method to provide electrospun scaffolds from a block-copolymer - poly (ethylene oxide terephthalate) - poly (buthylene terephthalate), with a calcium phosphate layer to improve their bioactivity in bone tissue engineering. The in vitro studies with human mesenchymal stem cells demonstrated cell proliferation on both uncoated and coated samples. No significant effect of calcium-phosphate coating was observed on the expression of alkaline phosphatase in vitro. Implantation of scaffold-goat mesenchymal stem cells constructs subcutaneously in nude mice resulted in bone formation in the calcium phosphate coated samples, in contrast to the uncoated ones, where no new bone formation was observed. The results of this study showed that the biomimetic method can successfully be used to coat electrospun scaffolds with a calcium-phosphate layer, which improved the in vivo bioactivity of the polymer. 


\section{INTRODUCTION}

$\mathbf{R}$ ecent advances in scaffolding technologies allow for development Rof well-defined complex structures consisting of one or more materials with the goal of optimising the function of tissue engineering constructs. Bone tissue engineering is an application where a combination of polymers, with their structural diversity and excellent mechanical properties, and highly bioactive calcium-phosphates is clearly beneficial for the characteristics [1] of the final scaffold. Electrospinning has been widely used to create fibrous meshes of a variety of polymers for tissue engineering applications [2-3]. It is a simple and powerful technique that involves the application of high voltage to polymer solutions or melts to obtain fibres in the nanometre to micrometre range[4-5]. The polymer-solvent combination and concentration, flow rate, voltage, collector distance, along with external factors like humidity, influence the outcome leading to fibres of different diameters and surface morphologies [6-9]. Electrospun fibrous meshes can be used as a delivery vehicle for drugs, proteins and other growth factors [10-11] or as a carrier of cells for regenerating tissue function [2-3]. Polymers can be combined with calcium phosphates in a number of ways, e.g. by forming bulk composite scaffolds or by coating the polymer surface with a calcium-phosphate layer using various techniques. In a recent study by Kim and co-workers, silk fibres were premineralised by combining them with polyaspartic acid, followed by soaking in solutions of $\mathrm{CaCl}_{2}$ and $\mathrm{Na}_{2} \mathrm{HPO}_{4}$ and freeze drying, with the goal of improving the osteogenic capacity of silk [12]. Yang et al. were able to produce nano-hydroxyapatite - polycaprolactone (PCL) composite scaffolds using electrospinning.[13]

Plasma spraying is the classical coating method for providing metallic implants with hydroxyapatite for total hip arthroplasty[14]. Although plasma spraying has led to excellent clinical results[15], its use is associated with important drawbacks. This line-of-sight process does not allow coating of geometrically complex and porous shapes. Furthermore, its use is limited to hydroxyapatite and other thermally stable calcium phosphate phases[16], due to very high processing temperature. In the recent years, several techniques have been investigated as an alternative to the plasma spraying process in order to overcome some of its limitations. Techniques like thermal spraying, sputter coat- 
ing, pulsed laser deposition and dynamic mixing are line-of-sight techniques but they offer other advantages such as high deposition rates (thermal spraying), uniform coating thickness (sputter coating), crystalline and amorphous coatings (pulsed laser deposition) and high adhesive strength (dynamic mixing method). Dip coating, sol-gel, electrophoretic deposition and biomimetic coating methods can be used to coat complex shapes.[17] Biomimetic coating methods based on the immersion of implants in solutions resembling body fluids have been developed to coat polymeric and metallic substrates [18-20]. In a recent study, three dimensional poly-lactic-glycolic acid (PLGA) scaffolds were coated with hydroxyapatite using a supersaturated Simulated Body Fluid (SBF) solution [21]. Combining bioactive but brittle ceramics with a mechanically strong and processable polymer seems to be a logical approach for the design of scaffolds for bone tissue engineering. Poly (ethylene oxide terephthalate) - poly (buthylene terephthalate) (PEOT/PBT), is a block co-polymer whose properties can be tailored for different applications by varying the composition of the PEOT and PBT. These polymers have been widely used in tissue engineering of bone [18] and cartilage [22]. PEOT/PBT co-polymers have been electrospun before [7], but this is the first time they have been tested in vivo for bone formation, alone or in combination with a calcium phosphate coating. Although fibre matrices of other polymers have been tested for in vivo bone formation in cranial defect models in rats [23] and rabbits [24], ectopic bone formation in a mouse model has only be assessed in one study [25]. The goal of this study was to electrospin PEOT/PBT co-polymers; functionalise them by applying a thin calcium phosphate coating on their surface, evaluate cell attachment and osteogenic ability in vitro and assess the bioactivity of the resulting scaffold with a proof of concept in vivo experiment. We hypothesise that the calcium phosphate coating will impart bioactivity to the polymeric scaffold leading to enhanced osteogenic potential in vitro and in vivo.

\section{MATERIALS AND METHODS}

DEOT/PBT block co-polymer was obtained from PolyVation BV, 1 The Netherlands. Following an aPEOTbPBTc nomenclature, the composition used in this study was 300PEOT55PBT45 where, (a) is 
the molecular weight in $\mathrm{g} / \mathrm{mol}$ of the starting poly(ethylene glycol) (PEG) blocks used in the copolymerisation, while (b) and (c) are the weight ratios of the PEOT and PBT blocks, respectively. All the salts and reagents used for the preparation of the coating were purchased at either Merck or Sigma-Aldrich.

\section{ELECTROSPINNING}

Known amounts of PEOT/PBT were dissolved in a mixture of chloroform - hexafluoroisopropanol (HFIP) $(78 \%-22 \% \mathrm{v} / \mathrm{v})$ respectively. A $28 \%(\mathrm{w} / \mathrm{v}) \mathrm{PEOT} / \mathrm{PBT}$ solution in chloroform - HFIP were prepared and stirred overnight at room temperature. The PEOT/PBT solution was loaded into a syringe and a desired flow rate was set using a syringe pump (KDS 100, KD Scientific). The other end of the syringe was connected to a needle which acted as the positive pole when a high voltage generator (NCE 30000, Heinzinger Electronic GmbH, Germany) was turned on. A metallic sheet of stainless steel was the collector (ground). An electrostatic field was formed between the needle and the collector when the generator was turned on. The polymer solution was pushed through the syringe to the tip of the needle through a flexible PTFE tubing. When the electrostatic field strength overcame the surface tension of the liquid drop at the tip of the needle, the drop was stretched and deposited onto the collector. The voltage was fixed at 12 $\mathrm{kV}$ for all conditions. The distance between the needle and collector was set at $15 \mathrm{~cm}$. As environmental conditions like temperature and humidity affect the process, flow rates of 15,20 and $25 \mathrm{~mL} / \mathrm{hr}$ were used to obtain fibres of identical diameters.

\section{PREPARATION OF BIOMIMETIC COATINGS ON ELECTROSPUN SCAFFOLDS}

Electrospun scaffolds (15mm in diameter) were coated with calciumphosphate using a two step coating process. In the first step, a five times concentrated simulated body fluid solution ( $\mathrm{SBFx} 5)$ was prepared by dissolving reagent grade $\mathrm{NaCl}(40 \mathrm{~g}), \mathrm{CaCl}_{2} .2 \mathrm{H}_{2} \mathrm{O}(1.84 \mathrm{~g})$, $\mathrm{MgCl}_{2} \cdot 6 \mathrm{H}_{2} \mathrm{O}(1.52 \mathrm{~g}), \mathrm{NaHCO}_{3}(1.76 \mathrm{~g})$ and $\mathrm{Na}_{2} \mathrm{HPO}_{4} \cdot 2 \mathrm{H}_{2} \mathrm{O}(0.89 \mathrm{~g})$ salts in 11 of demineralised water at $37^{\circ} \mathrm{C}$ under $\mathrm{CO}_{2}$ gas bubbling. The $\mathrm{CO}_{2}$ source was then removed from the solution and electrospun discs 
were immersed in the solution in a partly open vial and left to coat for 24 hours under continuous gentle stirring at $37^{\circ} \mathrm{C}$. This process was previously shown to result in a formation of thin, amorphous calciumphosphate layer.

In the second step, electrospun discs pre-coated in step 1 were immersed in a calcium phosphate solution (CPS) at physiological $\mathrm{pH}$ of 7.4 and temperature of $37^{\circ} \mathrm{C}$ for 24 hours to deposit a crystallised layer onto previously formed amorphous calcium-phosphate layer. CPS was prepared by dissolving $\mathrm{NaCl}(8 \mathrm{~g}), \mathrm{CaCl}_{2} \cdot 2 \mathrm{H}_{2} \mathrm{O}(0.59 \mathrm{~g}), \mathrm{Na}_{2} \mathrm{HPO}_{4} \cdot \mathrm{H}_{2} \mathrm{O}$ $(0.36 \mathrm{~g})$ and Tris $(6.05 \mathrm{~g})$ in MilliQ water and the $\mathrm{pH}$ of the solution was adjusted to 7.4 with $1 \mathrm{M} \mathrm{HCl}$. The coated electrospun discs were thoroughly washed in MilliQ water and dried overnight at $50^{\circ} \mathrm{C}$.

\section{CHARACTERISATION OF SCAFFOLDS}

The amount of coating in the scaffolds was calculated by weighing the dried scaffolds $(n=60)$ before and after the coating process. The architecture and composition of coated and uncoated scaffolds were characterised using Environmental Scanning Electron Microscopy (ESEM) in secondary electron mode coupled to Energy Dispersive X-Ray (EDX) analyser (XL 30 ESEM - FEG, Philips). Fourier transform infra red spectroscopy (FTIR) (Perkin Elmer Spectrum 1000) was performed on the coated fibre meshes and X-Ray Diffraction (Rigaku-Miniflex, Japan) was performed on coatings deposited on titanium alloy (Ti6Al4V) plates in the same solution as it was not possible to obtain the required amount of coating needed for the test from electrospun discs. Contact angle was measured on thin dense polymer films using a Dataphysics OCA 20 contact angle system. Triplicate measurements were made on three solvent cast films. Electrospun discs were not used for this test as water infiltration into the pores of matrices affected the reliability of the measurement. When coated samples were measured, the water droplet spread too rapidly indicating high hydrophilicity of the surface due to the presence of the coating and no measurements were possible. Porosity was calculated using density measurements $(n=3)$ from a pycnometer (AccuPyc 1330, Micromeritics). Fibre diameters of electrospun scaffolds were measured from ESEM images using image analysis software (SemAfore). A total of 45 fibres were measured for each condition. The diameters of the coated fibres were measured 
using ESEM and the thickness of the coating was obtained using the following formula;

Coating thickness $=($ Diameter of coated fibre - Mean diameter of uncoated fibre) $/ 2$.

A total of 10 coated fibres were measured.

\section{HUMAN MESENCHYMAL STEM CELl (HMSC) ASPIRATION AND EXPANSION}

Bone marrow aspirates were obtained from donors after written informed consent, and hMSCs were isolated and proliferated as described previously[26]. Briefly, aspirates were resuspended by using 20-gauge needles, plated at a density of $5 \times 10^{5} \mathrm{cells} / \mathrm{cm}^{2}$ and cultured in hMSC proliferation medium containing $\alpha$-MEM (Life Technologies), 10\% FBS (Cambrex), $0.2 \mathrm{mM}$ ascorbic acid (Asap; Life Technologies), 2 mM l-glutamine (Life Technologies), 100 units/ml penicillin (Life Technologies), $10 \mu \mathrm{g} / \mathrm{ml}$ streptomycin (Life Technologies), and $1 \mathrm{ng} /$ $\mathrm{ml}$ basic FGF (Instruchemie). Cells were grown at $37^{\circ} \mathrm{C}$ in a humid atmosphere with $5 \% \mathrm{CO}_{2}$. Medium was refreshed twice a week, and cells were used for further sub-culturing or cryopreservation. The hMSC basic medium was composed of hMSC proliferation medium without basic FGF, and hMSC osteogenic medium was composed of hMSC basic medium supplemented with $10^{-8} \mathrm{M}$ dexamethasone (Sigma). Cells were trypsinised prior to seeding on scaffolds.

\section{IN VITRO EXPERIMENT}

The in vitro experiments were performed with cells from one donor and repeated three times. Uncoated and coated electrospun discs with a diameter of $15 \mathrm{~mm}$ (thickness about $80 \mu \mathrm{m}$ for uncoated and about 230 $\mu \mathrm{m}$ for coated scaffolds) were soaked in $70 \%$ ethanol for 30 minutes and left overnight in a laminar flow cabinet to dry. The scaffolds were washed twice with sterile PBS, transferred to a 24 well non-treated plate (NUNC) and incubated at $37^{\circ} \mathrm{C}$ in a humid atmosphere with $5 \%$ $\mathrm{CO}_{2}$ for four hours in basic cell culture medium. After removing the medium, each scaffold was seeded with 15,000 cells from passage 3 in $50 \mu \mathrm{l}$ basic medium. The cell-scaffold constructs were incubated for three hours to allow the cells to attach and topped up to $1 \mathrm{ml}$ with 
the appropriate medium (basic or osteogenic). Medium was refreshed every three days.

The scaffolds were washed with PBS and $200 \mu 1$ of cell lysis buffer containing $0.2 \%$ Triton $\mathrm{X}-100$ buffered with $0.1 \mathrm{M}$ potassium-phosphate at $\mathrm{pH} 7.8$ was added to the scaffolds to lyse the cells. After 30 minutes, the cell lysates were transferred to Eppendorf tubes and stored at $-80^{\circ} \mathrm{C}$.

\section{DNA ASSAY}

DNA assay was performed on days 1, 7 and 14 of cell culture. Cell numbers were determined using the CyQUANT ${ }^{\circledR}$ DNA quantification kit (Invitrogen) with $50 \mu \mathrm{l}$ of cell lysate according to the manufacturer's protocol. Fluorescence at an excitation wavelength of $480 \mathrm{~nm}$ and an emission wavelength of $520 \mathrm{~nm}$ was measured using a Perkin Elmer LS50B plate reader.

\section{ALP ASSAY}

ALP activity was assessed biochemically on days 7 and $14.40 \mu 1$ of CDP-starTM reagent (Roche) was added to a $10 \mu 1$ aliquot of cell lysate and incubated for 30 minutes in the dark at $25^{\circ} \mathrm{C}$. Chemo luminescence was measured in a Victor plate reader (Perkin Elmer, Wellesley, MA, USA).

\section{IN VIVO STUDY}

Goat mesenchymal stem cell (gMSC) aspirates were isolated from the iliac crest of adult Dutch milk goats after an approval by the local Animal Care and Use Committee (DEC) (DEC, Utrecht, the Netherlands) and cultured as previously described [27]. Culture medium consisted of $\alpha$-MEM supplemented with $15 \%$ FBS, antibiotics, $0.1 \mathrm{mM}$ 1-ascorbic acid-2-phosphate, $2 \mathrm{mM} 1$-glutamine and $1 \mathrm{ng} / \mathrm{ml}$ basic fibroblast growth factor (Instruchemie, The Netherlands)[28]. Cells were cultured at $37{ }^{\circ} \mathrm{C}$ in a humid atmosphere with $5 \% \mathrm{CO}_{2}$. Cells were either cryopreserved or subcultured further. 200,000 gMSCs of passage 3 were seeded on $7 \mathrm{~mm}$ x $5 \mathrm{~mm}$ scaffolds (thickness - $80 \mu \mathrm{m}$ for uncoated and $230 \mu \mathrm{m}$ for coated scaffolds) in basic cell culture medium containing 
$15 \%$ FBS (Cambrex). Cells were allowed to attach overnight at $37^{\circ} \mathrm{C}$ in a humid atmosphere with $5 \% \mathrm{CO}_{2}$ before implantation.

\section{SUBCUTANEOUS IMPLANTATION}

Uncoated and coated electrospun PEOT/PBT scaffolds seeded with goat MSCs were implanted subcutaneously in immuno-deficient mice obtained from Charles River laboratories, The Netherlands (Crl:NMRIFoxn $1<\mathrm{nu}>$ ) to assess ectopic bone formation.

Animals were housed at the Central Laboratory Animal Institute (Utrecht University, The Netherlands). All animal experiments were approved by the local Animal Care and Use Committee (DEC) and performed in adherence to the local and national ethics guidelines. Prior to implantation, the tissue-engineered constructs were washed with sterile PBS. Six mice were anesthetised using isoflurane. The surgical sites at the back of the animals were cleaned with ethanol, subcutaneous pockets were created using blunt incision and one uncoated and coated construct were implanted. The sites were closed using resorbable vicryl 4-0 sutures. After 6 weeks, the animals were euthanised and the implants were retrieved and fixed in $4 \%$ formalin. The fixed samples were washed with PBS, dehydrated in ethanol series $(70 \%, 80 \%, 90 \%, 96 \%$, and $100 \% \times 2$, one day in each concentration) and embedded in methyl methacrylate. Sections with a thickness of approximately $10-15 \mu \mathrm{m}$ were obtained using a histological diamond saw (Leica SP1600, Wetzlar, Germany) and stained with 1\% methylene blue (Sigma) and $0.3 \%$ basic fuchsin solution (Sigma) after etching with $\mathrm{HCl} /$ ethanol mixture. The sections were observed using a Nikon Eclipse E600 microscope.

\section{STATISTICAL ANALYSIS}

Statistical analysis on the in vitro data were performed in SPSS 16.0 software using a one way ANOVA test with a Bonferroni Post Hoc comparison. The level of significance was set at 0.05 . 


\section{RESULTS AND DISCUSSION}

\section{MATERIAL PREPARATION AND CHARACTERISATION}

$\mathrm{E}$ lectrospun scaffolds of PEOT/PBT were successfully fabricated. Figures $1 \mathrm{~A}$ and $1 \mathrm{~B}$ show ESEM micrographs of uncoated electrospun fibre mats at different magnifications. The diameter, porosity and the contact angle were measured and are shown in Table 1. The average fibre diameter was $6.5 \mu \mathrm{m}$ and the porosity was determined to be $68.5 \%$. A contact angle of $66.8^{\circ}$ indicated that the polymer was weakly hydrophilic. The effect of humidity on fibre diameter[9, 29] and morphology [8] of electrospun fibres has been shown previously.

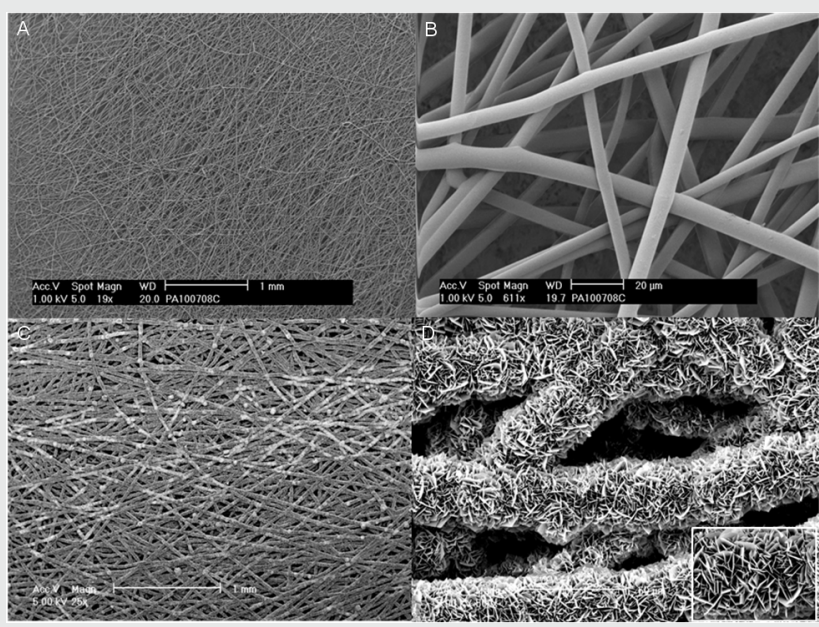

consisted of large platelet-shaped crystals (insert in D). Scale bars for A and C-1mm,

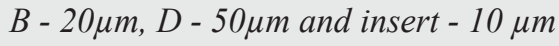

Figure 1: ESEM micrographs of uncoated PEOT/PBT fibres at low (A) and high (B) magnification and of calciumphosphate coated PEOT/PBT fibres at low (C) and high (D) magnification. The insert in $D$ shows the morphology of calcium phosphate coating at high magnification (2500x). The uncoated fibres were smooth and of uniform diameter (A, B). The calcium phosphate coating was homogenously present across the whole scaffold $(C, D)$ and

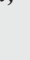
Scale bars for $A$ and $C$ - 1 mm,

The fibre diameter increases or decreases with increasing humidity depending on the chemical nature of the polymer. Since it was not possible to control the relative humidity in our setup, different flow rates $(15,20$ and $25 \mathrm{~mL} / \mathrm{hr})$ had to be used on different days to obtain fibres with a similar diameter. In earlier studies, electrospinning was used to produce polymeric meshes consisting of fibres in the nanometre to micrometre range of a large number and polymers. Electrospun scaf- 
folds have found their applications in a variety of tissue engineering applications such as vascular reconstruction [30], nerve regeneration [31],cartilage tissue engineering [32] and bone regeneration [33].

To provide the electrospun fibres with a calcium phosphate layer, a biomimetic coating process was used. This process resulted in a uniform deposition of a mineral layer as shown in Figures 1C and 1D. The coating thickness was calculated to be $13.2 \pm 1.9 \mu \mathrm{m}$ and accounted for 25 wt. $\%$ of the total implant (Table 1). EDX mapping of $\mathrm{Ca}, \mathrm{P}$ and $\mathrm{O}$ (Supporting figure 1) confirmed that the coating was uniformly present over the entire surface. Similar biomimetic processes have been previously used to coat various substrates like titanium and injection moulded polymers with a calcium-phosphate layer [18-19].

As the biomimetic coating process takes place at physiological $\mathrm{pH}$ and low temperatures, it allows coating of polymers which cannot be subjected to very high temperatures. The process is also suited for the addition of bioactive agents such as proteins [34] and growth factors[35] to the coating, which would not be possible if a classical technique such as plasma spraying was used. Furthermore, the biomimetic coating process that takes place in aqueous solutions can be used for coating porous and other geometrically complex shapes.

\begin{tabular}{|c|c|c|c|c|c|}
\hline $\begin{array}{l}\text { Solution- } \\
\text { concen- } \\
\text { tration } \\
(\mathrm{w} / \mathrm{v}) \%\end{array}$ & $\begin{array}{l}\text { Flow rate } \\
(\mathrm{mL} / \mathrm{hr})\end{array}$ & $\begin{array}{l}\text { Fibre } \\
\text { diameter } \\
(\mu \mathrm{m})\end{array}$ & $\begin{array}{l}\text { Porosity } \\
(\%)\end{array}$ & $\begin{array}{l}\text { Contact } \\
\text { angle }\left(^{\circ}\right)\end{array}$ & $\begin{array}{l}\text { Amount } \\
\text { of coating } \\
(\%)\end{array}$ \\
\hline $\begin{array}{l}28 \% \text { in } \\
78 / 22 \\
\mathrm{CHCl}_{3}- \\
\mathrm{HFIP}\end{array}$ & $15,20,25$ & $\begin{array}{l}6.47 \pm \\
1.46\end{array}$ & $68.5 \pm 2.2$ & $\begin{array}{l}66.8 \pm \\
3.65\end{array}$ & $\begin{array}{l}24.47 \pm \\
6.13\end{array}$ \\
\hline
\end{tabular}

Table 1: Characterisation of electrospun fibres. Voltage $=12 \mathrm{kV}$, distance $=$ $15 \mathrm{~cm}$

The FTIR spectra in Figure 2 indicate the presence of typical P-O bands at $560 \mathrm{~cm}^{-1}$ and $600 \mathrm{~cm}^{-1}$. HPO4 ${ }^{2-}$ bands characteristic of octacalcium phosphate (OCP) were observed at $906 \mathrm{~cm}^{-1}$ and $852 \mathrm{~cm}^{-1}$. In addition, the spectrum showed carbonate bands at $1410 \mathrm{~cm}^{-1}$ and $1450 \mathrm{~cm}^{-1}$, suggesting presence of some carbonate in the coating. It 
is conceivable that this carbonate was mainly present in the thin, pre-

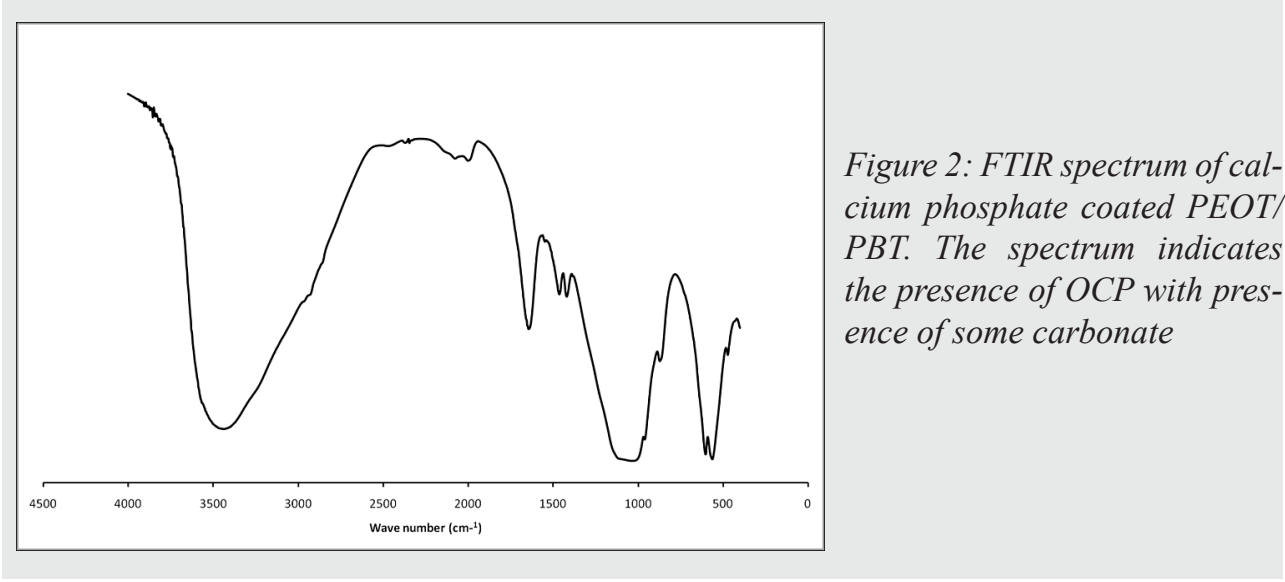

calcification layer of the coating, which was deposited from a super-

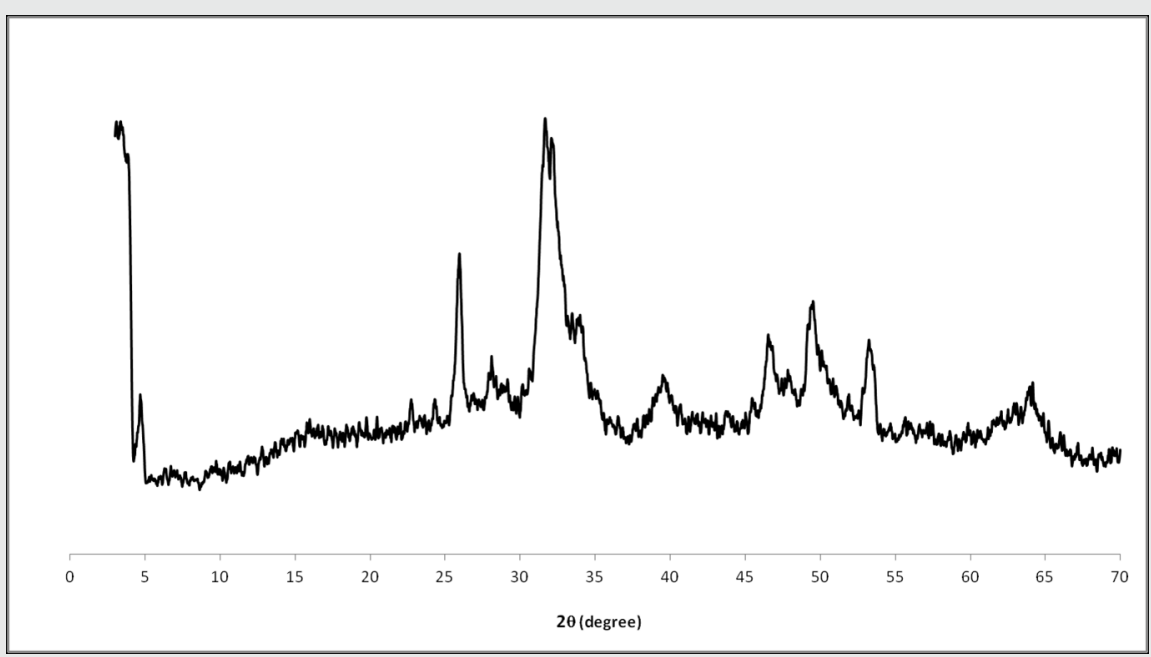

Figure 3: X-Ray diffraction pattern of crystals formed after the calcium phosphate coating process. The OCP phase of the coating was confirmed by the presence of a characteristic peak at $4.7^{\circ}$

saturated solution, obtained by bubbling of $\mathrm{CO}_{2}$ gas to decrease its $\mathrm{pH}$. The FTIR spectrum was similar to the ones obtained by Barrere et al. [20] in previous studies aimed to coat titanium alloy substrates 
for orthopaedic applications. Figure 3 illustrates the XRD pattern of the coating. The XRD pattern confirmed the OCP phase of the coating with a characteristic peak at $4.7^{\circ}$. As mentioned before, the XRD analysis was performed on coatings deposited on Ti alloy substrates in the same solution as electrospun scaffolds due to practical considerations. ESEM micrographs on both substrates (not shown) showed that a similar morphology of the coatings.

\section{IN VITRO STUDY}

\section{CELL PROLIFERATION}

HMSCs were cultured on electrospun scaffolds and the results of DNA assay on days 1, 7 and 14 are summarised in Figure 4. The results showed that cells were able to proliferate on both uncoated and calcium-phosphate coated electrospun scaffolds of PEOT/PBT. The culture medium and the coating did not have a significant effect on cell num-

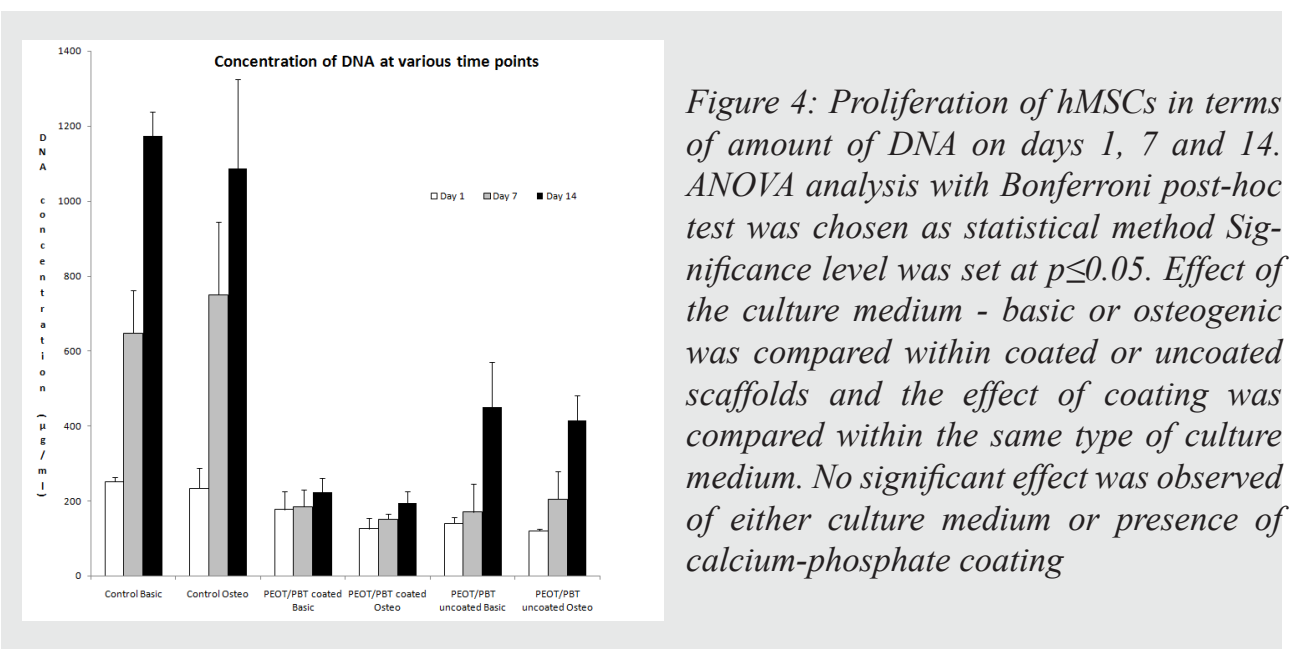

bers at different time points of culture. Li et al. [36] observed a significantly higher number of MC3T3-E1 cells on mineralised electrospun PCL scaffolds compared to untreated ones after 7 days. However, these fibre meshes were also coated with gelatin prior to the calcium phosphate coating. Presence of calcium-phosphate has not always shown to be beneficial in proliferation of (pre)osteoblastic cells. Anselme and 
co-workers studied the in vitro growth of human bone derived cells on surfaces plasma sprayed with hydroxyapatite[37] and observed low cell growth on coated surfaces compared to plastic. They suggested that the dissolution and precipitation of hydroxyapatite coatings could prevent human bone derived cells from attaching to the surface in the first two weeks of in vitro culture. In another study involving culture of MC3T3-E1 preosteoblasts on different apatite structures[38], cell density was found to be highest on tissue culture plastic after 14 days. The increase in the concentration of phosphate ions in the culture medium due to the dissolution of the coating was hypothesised as a possible reason for reduced proliferation as compared to the plastic control[39]. These studies show, that depending on the experimental in vitro setting, calcium-phosphates can either positively or negatively affect proliferation of osteoblasts.

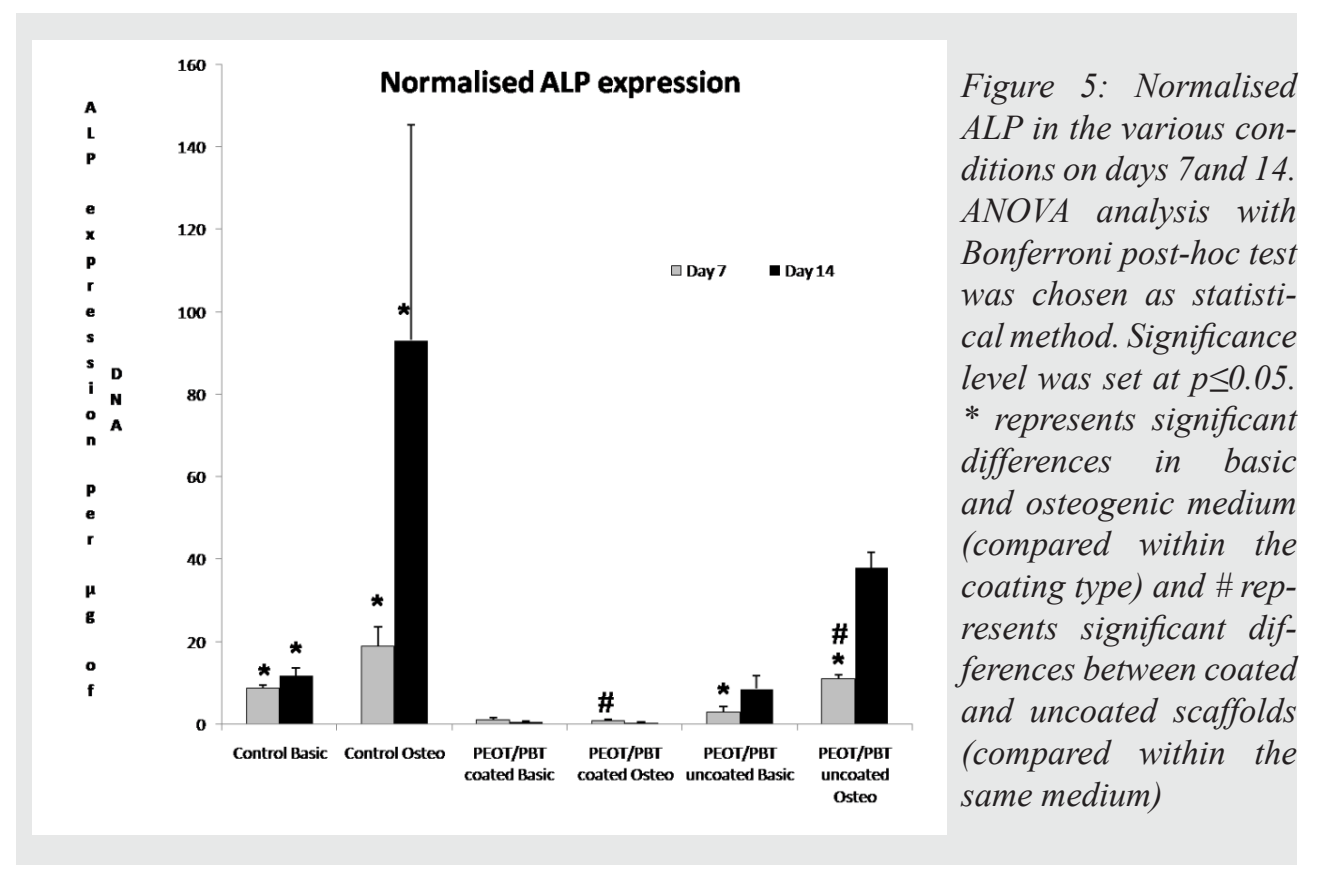

For the in vivo study, we wanted all the constructs to have the same number of cells at the time of implantation and hence we have chosen to use peroperative seeding as described by Siddappa et al. [40]. As was shown by Siddappa et al. [40] and from our prior experience, hMSCs seeded peroperatively do not lead to in vivo bone formation in 
subcutaneous nude mouse model independent on the scaffold type, in contrast to gMSCs. We have therefore chosen gMSCs for the in vivo part of this study, where ectopic bone formation of the constructs was tested.

\section{OSTEOGENIC DIFFERENTIATION}

Alkaline Phosphatase (ALP) is an early osteogenic marker and ALP expression of the hMSCs cultured on the scaffolds was measured on days 7 and 14. The normalised ALP expression is shown in Figure 5. As expected, on days 7 and 14, the osteogenic medium had significantly increased ALP expression in control tissue culture plates without scaffold compared to cells cultured in the basic medium. On day 7 , the effect of osteogenic medium was evident in the uncoated electrospun samples as well, but not in the coated ones. When the effect of coatings was analysed on day 7 , uncoated samples had a significantly higher ALP expression. On day 14, no significant differences were observed in ALP activity between the uncoated and coated samples. Furthermore, no significant effect of the differentiation medium was observed on either uncoated or coated samples.

Anh and co-workers measured ALP activity in human osteosarcoma (SaOS-2) cells and primary human bone cells [41]. They showed that calcium negatively regulates the net release of ALP activity. This might explain the significantly higher ALP expression on day 7 in the uncoated samples (in osteogenic medium) compared to the coated samples. In a recent study, Haimi et al. [42] cultured adipose tissue-derived stem cells, which have to potential to differentiate into the osteogenic lineage, on bioactive glass with different thicknesses of calcium phosphate coating. They observed the highest ALP expression in samples without coating and the lowest ALP expression in the samples with thickest calcium phosphate coating. These significant differences were observed in week 1 of the culture. They attributed this trend to the presence of a calcium rich environment in the coated samples which might delay the onset of osteogenic differentiation and lead to a lower ALP expression, since ALP is an early marker for osteogenesis. In our study, uncoated electrospun scaffolds showed higher ALP expression than the coated ones on day 7 , whereas no difference was found on day 14 , which could also be caused by the delay in onset of osteogenic dif- 
ferentiation of hMSCs in presence on calcium-phosphate coating. The time points at which we assessed the ALP expression of hMSCs were chosen based on the literature. Future experiments are needed to investigate whether the onset of ALP expression is indeed delayed due to the presence of calcium phosphate coating in the system tested here. Yang et al. [13] observed higher ALP expression of rat bone marrow cells in electrospun nano-apatite - PCL scaffolds. However, the amount of

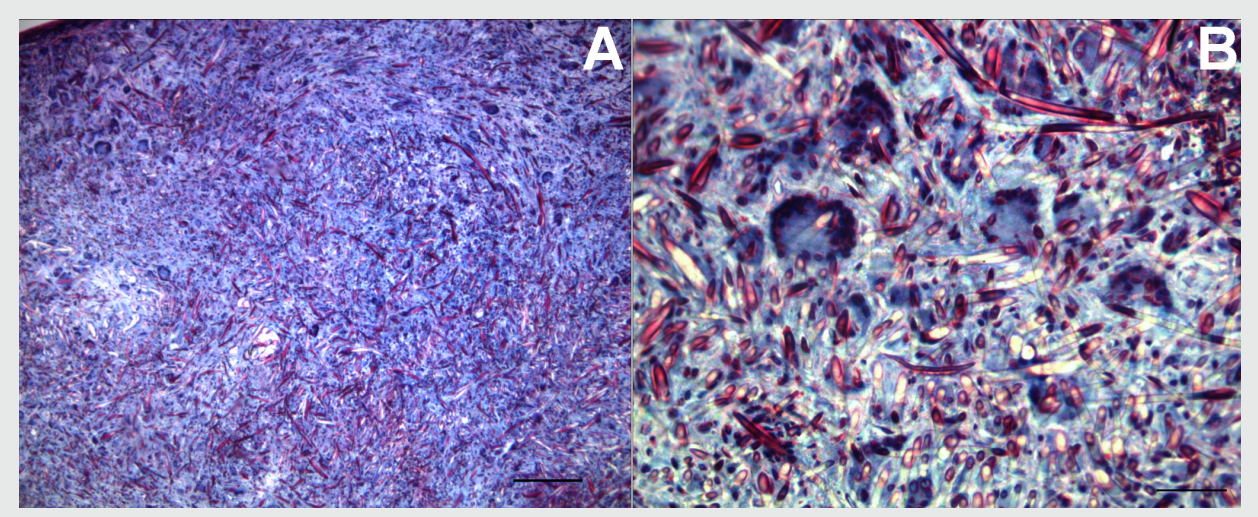

Figure 6: Histological sections from the in vivo study after Methylene blue and Basic fuchsin staining of uncoated PEOT/PBT at low (A) and high (B) magnifications. The scaffolds show the presence of macrophages $(B)$ and fibrous tissue but no bone formation. Scale bars: $A$ $250 \mu \mathrm{m} . \mathrm{B}-50 \mu \mathrm{m}$

calcium-phosphate available to cells in a composite material such as electrospun apatite - PCL construct is plausibly lower compared to a scaffold that has been electrospun and surface coated with calciumphosphate.

It is well known that the in vitro and in vivo microenvironment around a tissue engineered construct greatly differ [37]. While in vivo, the body fluids around an implant are continuously replenished [37, 39], the in vitro microenvironment is rather closed and static. As a result, events occurring on the surface of calcium-phosphate coatings and their effect on cells of the construct are expected to be different in vitro and in vivo. We have recently reviewed limitations of current in vitro methods in predicting the in vivo behaviour of calcium-phosphate bone graft substitutes[43] and showed that caution and care are needed while interpreting and extrapolating in vitro results of bioactive im- 


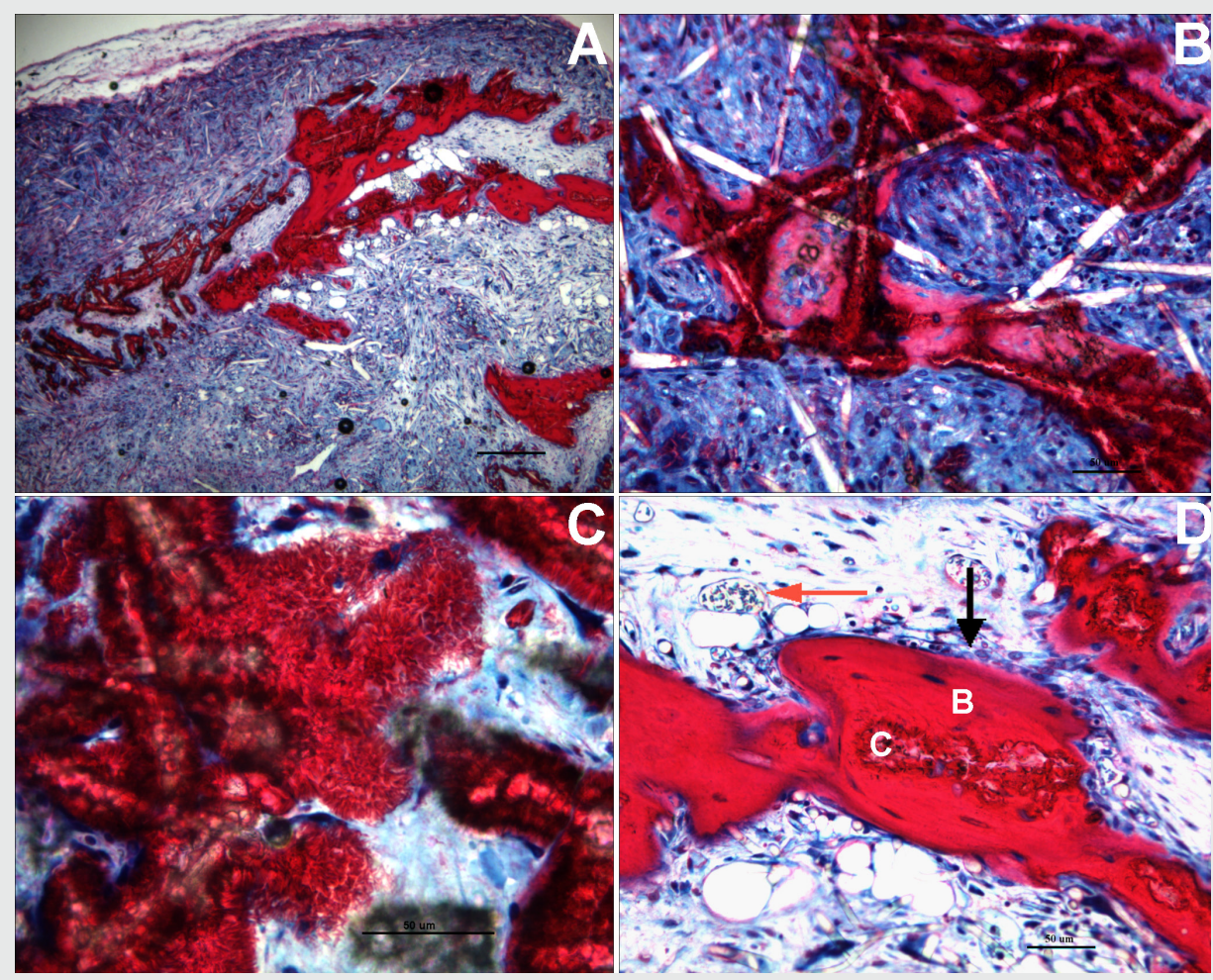

Figure 7: Histological sections from the in vivo study after Methylene blue and Basic fuchsin staining of calcium-phosphate coated PEOT/PBT. (A) Bone formation under low magnification, (B) Early (pink) stage of bone formation, (C) Early mineralisation under high magnification, (D) Biomimetic coating $C$ and bone $B$. The red arrow indicates erythrocyte like cells present in the vicinity of the bone. The black arrow indicates bone lining cells. Scale bars. $A-250 \mu \mathrm{m}, B, C$ and $D-50 \mu m$

plant surfaces to their in vivo behaviour. We have therefore decided to assess in vivo bone forming ability the electrospun coated fibre matrix/ gMSCs constructs, despite the fact that no effect of calcium-phosphate coating was observed in vitro.

\section{IN VIVO STUDY}

The in vivo study showed no bone formation in any of the uncoated polymeric meshes loaded with gMSCs (Figure 6A). Some multi-nucleated giant cells were present suggesting a mild inflammatory response (Figure 6B). Bone formation was observed in four out of six coated constructs (Figures 7A-D). Bone formation was observed in some re- 
gions of the scaffold, rather than being uniformly distributed throughout the fibre matrix. There were no preferred regions for bone formation that was observed in the center of the implant in some cases and

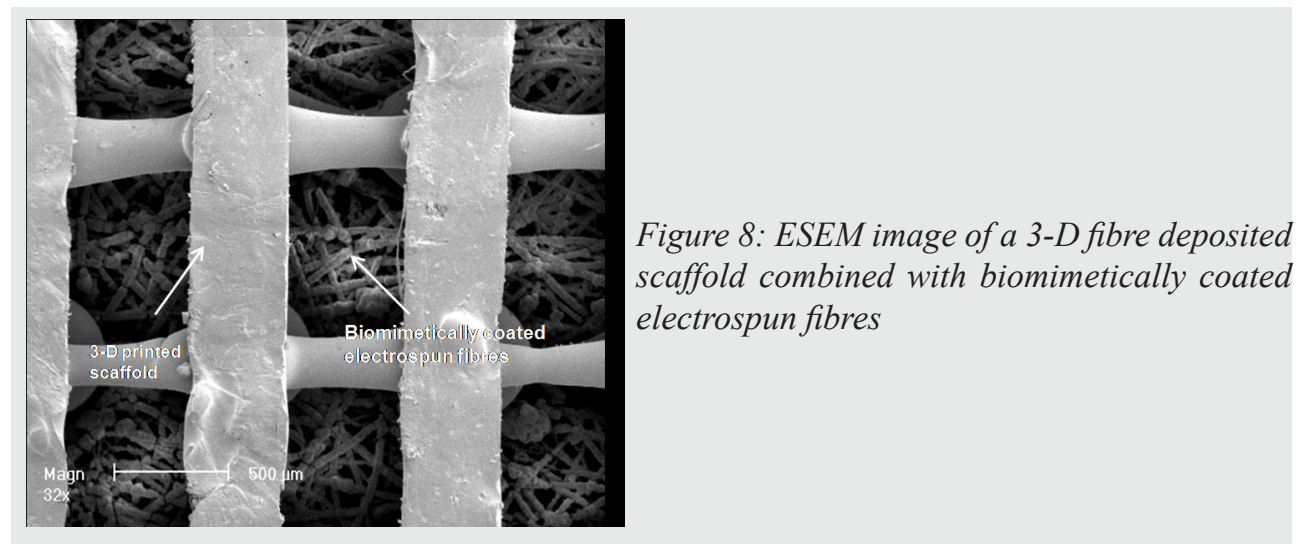

in the periphery in other cases. In some areas of constructs with bone formation, new mineral formation similar to osteoid was observed, but no osteocyte or bone lining cells were found (Figure 7B, C). In other areas, presence of new bone was observed, which was natural in appearance, with osteoid containing osteocytes and osteoblasts aligning new bone (Figure 7D). In general, bone formed had an immature, woven appearance. The in vivo experiments showed that the uncoated scaffolds combined with gMSCs did not lead to bone formation, in contrast to the coated scaffolds.

Before implantation, gMSCs were expanded and allowed to attach to scaffolds in basic cell culture medium meaning that the cell culture medium could not have provided the osteogenic stimuli to the cells to trigger bone formation upon ectopic implantation, suggesting that the trigger was the calcium-phosphate coating itself. Porous PEOT/ PBT scaffolds previously showed bone ingrowth and in vivo calcification when implanted in the femur of goats[44]. Biomimetic calcium phosphate coatings, similar to the one described in this study have led to bone formation inside porous metallic implants in rats[45] and goats[19]. Upon implantation, calcium phosphate coatings start dissolving [46], releasing thereby calcium and phosphate ions. The ions released were shown to play an important role in early mineralisation and early bone conduction [47-48] leading to the formation of a bio- 
logical CaP layer [48]. Ducheyne et al. [49] stated that the calcium phosphate coatings derive their bioactivity by providing a local ion source and elucidate the solution mediated effects of $\mathrm{CaP}$ coatings on bone formation.

Although electrospinning is an attractive technique to provide an environment for cell attachment similar to that of extracellular matrix, electrospun structures cannot be used as sole scaffold for load bearing applications in bone tissue engineering due to their poor mechanical properties. The combination of electrospinning with other scaffold fabrication technologies could lead to the development of a more complete scaffold for tissue engineering applications. Moroni et al. [50] showed that a combination of electrospun PEOT/PBT polymer mesh with a 3-D printed scaffold leads to enhanced cartilage tissue formation. More recently, Kuraishi et al. [51] used Polyurethane fibres to cover a stent in the treatment of cerebral aneurysms. Since this study has shown that calcium-phosphate coated PEOT/PBT fibres can initiate new bone formation by MSCs, the next step was to combine electrospun mats with a 3-D fibre deposited scaffold (Figure 8). The bioactive coated electrospun fibres in combination with the 3 -D scaffold whose mechanical properties can be tailored [52] based on the requirements, could therefore be a promising scaffold for bone tissue engineering.

\section{CONCLUSIONS}

耳 lectrospun scaffolds were prepared from PEOT/PBT block co-polymer and they were coated with a uniform calcium phosphate layer using a biomimetic coating process. In vitro experiments demonstrated the proliferation of cells on these scaffolds but did not show any appreciable difference in ALP expression when compared to uncoated scaffolds. In vivo experiments in a nude mouse model demonstrated the osteogenic ability of the coated fibres. These bioactive coated electrospun scaffolds, in combination with a mechanically more suitable 3-D scaffold could be used for bone tissue engineering applications. 


\section{ACKNOWLEDGEMENTS}

The authors thank Mr. Hugo Alves and Ms. Charlene Danoux for technical assistance and Dr. Lorenzo Moroni for his help with the preparation of the manuscript. This study was financially supported by the 6th Framework EC project STEPS (FP6-500465).

\section{REFERENCES}

1. Bhattacharyya S, Kumbar SG, Khan YM, Nair LS, Singh A, Krogman NR, et al. Biodegradable Polyphosphazene-Nanohydroxyapatite Composite Nanofibres: Scaffolds for Bone Tissue Engineering. Journal of Biomedical Nanotechnology 2009;5(1):69-75.

2. Li CM, Vepari C, Jin HJ, Kim HJ, Kaplan DL. Electrospun silk-BMP-2 scaffolds for bone tissue engineering. Biomaterials 2006;27(16):3115-3124.

3. Yang F, Murugan R, Wang S, Ramakrishna S. Electrospinning of nano/micro scale poly(L-lactic acid) aligned fibres and their potential in neural tissue engineering. Biomaterials 2005;26(15):2603-2610.

4. Doshi J, Reneker DH. Electrospinning Process and Applications of Electrospun Fibres. Journal of Electrostatics 1995;35(2-3):151-160.

5. Dalton PD, Grafahrend D, Klinkhammer K, Klee D, Moller M. Electrospinning of polymer melts: Phenomenological observations. Polymer 2007;48(23):6823-6833.

6. Deitzel JM, Kleinmeyer J, Harris D, Tan NCB. The effect of processing variables on the morphology of electrospun nanofibres and textiles. Polymer 2001;42(1):261-272.

7. Moroni L, Licht R, de Boer J, de Wijn JR, van Blitterswijk CA. Fibre diameter and texture of electrospun PEOT/PBT scaffolds influence human mesenchymal stem cell proliferation and morphology, and the release of incorporated compounds. Biomaterials 2006;27(28):49114922.

8. Casper CL, Stephens JS, Tassi NG, Chase DB, Rabolt JF. Controlling surface morphology of electrospun polystyrene fibres: Effect of humidity and molecular weight in the electrospinning process. Mac- 
romolecules 2004;37(2):573-578.

9. De Vrieze S, Van Camp T, Nelvig A, Hagstrom B, Westbroek P, De Clerck K. The effect of temperature and humidity on electrospinning. Journal of Materials Science 2009;44(5):1357-1362.

10. Neal RA, McClugage SG, Link MC, Sefcik LS, Ogle RC, Botchwey EA. Laminin Nanofibre Meshes That Mimic Morphological Properties and Bioactivity of Basement Membranes. Tissue Engineering Part C-Methods 2009;15(1):11-21.

11. Ranganath $\mathrm{SH}$, Wang $\mathrm{CH}$. Biodegradable microfibre implants delivering paclitaxel for post-surgical chemotherapy against malignant glioma. Biomaterials 2008;29(20):2996-3003.

12. Kim HJ, Kim UJ, Kim HS, Li CM, Wada M, Leisk GG, et al. Bone tissue engineering with premineralized silk scaffolds. Bone 2008;42(6):1226-1234.

13. Yang F, Both SK, Yang X, Walboomers XF, Jansen JA. Development of an electrospun nano-apatite/PCL composite membrane for GTR/GBR application. Acta Biomater 2009.

14. He DY, Sun XF, Zhao LD. Hydroxylapatite coatings by microplasma spraying. J Inorg Mater 2007;22(4):754-758.

15. Geesink RGT, Hoefnagels NHM. 6-Year Results of Hydroxyapatite-Coated Total Hip-Replacement. Journal of Bone and Joint Surgery-British Volume 1995;77B(4):534-547.

16. Ellies LG, Nelson DGA, Featherstone JDB. Crystallographic Changes in Calcium Phosphates during Plasma-Spraying. Biomaterials 1992;13(5):313-316.

17. Yang YZ, Kim KH, Ong JL. Review on calcium phosphate coatings produced using a sputtering process - an alternative to plasma spraying. Biomaterials 2005;26(3):327-337.

18. Du C, Meijer GJ, van de Valk C, Haan RE, Bezemer JM, Hesseling $\mathrm{SC}$, et al. Bone growth in biomimetic apatite coated porous Polyactive $((\mathrm{R}))$ 1000PEGT70PBT30 implants. Biomaterials 2002;23(23):4649-4656.

19. Habibovic P, Li JP, van der Valk CM, Meijer G, Layrolle P, van Blitterswijk CA, et al. Biological performance of uncoated and octa- 
calcium phosphate-coated Ti6A14V. Biomaterials 2005;26(1):23-36.

20. Barrere F, Layrolle P, van Blitterswijk CA, de Groot K. Biomimetic coatings on titanium: a crystal growth study of octacalcium phosphate. Journal of Materials Science-Materials in Medicine 2001;12(6):529-534.

21. Douglas T, Pamula E, Hauk D, Wiltfang J, Sivananthan S, Sherry E, et al. Porous polymer/hydroxyapatite scaffolds: characterization and biocompatibility investigations. Journal of Materials Science-Materials in Medicine 2009;20(9):1909-1915.

22. Woodfield TBF, Malda J, de Wijn J, Peters F, Riesle J, van Blitterswijk CA. Design of porous scaffolds for cartilage tissue engineering using a three-dimensional fibre-deposition technique. Biomaterials 2004;25(18):4149-4161.

23. Ko EK, Jeong SI, Rim NG, Lee YM, Shin H, Lee BK. In Vitro Osteogenic Differentiation of Human Mesenchymal Stem Cells and In Vivo Bone Formation in Composite Nanofibre Meshes. Tissue Engineering Part A 2008;14(12):2105-2119.

24. Seol YJ, Kim KH, Kang YM, Kim IA, Rhee SH. Bioactivity, PreOsteoblastic Cell Responses, and Osteoconductivity Evaluations of the Electrospun Non-Woven SiO2-CaO Gel Fabrics. Journal of Biomedical Materials Research Part B-Applied Biomaterials 2009;90B(2):679687.

25. Pelled G, Tai K, Sheyn D, Zilberman Y, Kumbar S, Nair LS, et al. Structural and nanoindentation studies of stem cell-based tissueengineered bone. J Biomech 2007;40(2):399-411.

26. Both SK, Van der Muijsenberg AJC, Van Blitterswijk CA, De Boer J, De Bruijn JD. A rapid and efficient method for expansion of human mesenchymal stem cells. Tissue Engineering 2007;13(1):3-9.

27. J.D. de Bruijn IvdB, Y.P. Bovell and C.A. van Blitterswijk. Tissue engineering of goat bone: osteogenic potential of goat bone marrow cells. Bioceramics 1998(11):497-500.

28. Janssen FW, Oostra J, van Oorschot A, van Blitterswijk CA. A perfusion bioreactor system capable of producing clinically relevant volumes of tissue-engineered bone: In vivo bone formation showing 
proof of concept. Biomaterials 2006;27(3):315-323.

29. Tripatanasuwan S, Zhong ZX, Reneker DH. Effect of evaporation and solidification of the charged jet in electrospinning of poly(ethylene oxide) aqueous solution. Polymer 2007;48(19):57425746.

30. Tillman BW, Yazdani SK, Lee SJ, Geary RL, Atala A, Yoo JJ. The in vivo stability of electrospun polycaprolactone-collagen scaffolds in vascular reconstruction. Biomaterials 2009;30(4):583-588.

31. Wang HB, Mullins ME, Cregg JM, Hurtado A, Oudega M, Trombley MT, et al. Creation of highly aligned electrospun poly-Llactic acid fibres for nerve regeneration applications. Journal of Neural Engineering 2009;6(1):-.

32. Li WJ, Tuli R, Okafor C, Derfoul A, Danielson KG, Hall DJ, et al. A three-dimensional nanofibrous scaffold for cartilage tissue engineering using human mesenchymal stem cells. Biomaterials 2005;26(6):599-609.

33. Fu YC, Nie H, Ho ML, Wang CK, Wang CH. Optimized bone regeneration based on sustained release from three-dimensional fibrous PLGA/HAp composite scaffolds loaded with BMP-2. Biotechnology and Bioengineering 2008;99(4):996-1006.

34. Liu YL, Layrolle P, van Blitterswijk C, de Groot K. Incorporation of proteins into biomimetic hydroxyapatite coatings. Bioceramics 2000;192-1:71-74.

35. Liu YL, Hunziker EB, Layrolle P, De Bruijn JD, De Groot K. Bone morphogenetic protein 2 incorporated into biomimetic coatings retains its biological activity. Tissue Engineering 2004;10(1-2):101108.

36. Li X, Xie J, Yuan X, Xia Y. Coating electrospun poly(epsiloncaprolactone) fibres with gelatin and calcium phosphate and their use as biomimetic scaffolds for bone tissue engineering. Langmuir 2008;24(24):14145-14150.

37. Anselme K, Sharrock P, Hardouin P, Dard M. In vitro growth of human adult bone-derived cells on hydroxyapatite plasma-sprayed coatings. J Biomed Mater Res 1997;34(2):247-259. 
38. Chou YF, Huang W, Dunn JC, Miller TA, Wu BM. The effect of biomimetic apatite structure on osteoblast viability, proliferation, and gene expression. Biomaterials 2005;26(3):285-295.

39. Knabe C, Klar F, Fitzner R, Radlanski RJ, Gross U. In vitro investigation of titanium and hydroxyapatite dental implant surfaces using a rat bone marrow stromal cell culture system. Biomaterials 2002;23(15):3235-3245.

40. Siddappa R, Martens A, Doorn J, Leusink A, Olivo C, Licht $\mathrm{R}$, et al. $\mathrm{cAMP} / \mathrm{PKA}$ pathway activation in human mesenchymal stem cells in vitro results in robust bone formation in vivo. Proceedings of the National Academy of Sciences of the United States of America 2008;105(20):7281-7286.

41. Anh DJ, Dimai HP, Hall SL, Farley JR. Skeletal alkaline phosphatase activity is primarily released from human osteoblasts in an insoluble form, and the net release is inhibited by calcium and skeletal growth factors. Calcif Tissue Int 1998;62(4):332-340.

42. Haimi S, Moimas L, Pirhonen E, Lindroos B, Huhtala H, Raty $\mathrm{S}$, et al. Calcium phosphate surface treatment of bioactive glass causes a delay in early osteogenic differentiation of adipose stem cells. J Biomed Mater Res A 2008.

43. Habibovic P, Woodfield T, de Groot K, van Blitterswijk C. Predictive value of in vitro and in vivo assays in bone and cartilage repair - What do they really tell us about the clinical performance? Tissue Engineering 2006;585:327-360.

44. Radder AM, Leenders H, vanBlitterswijk CA. Application of porous $\mathrm{PEO} / \mathrm{PBT}$ copolymers for bone replacement. Journal of Biomedical Materials Research 1996;30(3):341-351.

45. Dekker RJ, de Bruijn JD, Stigter M, Barrere F, Layrolle P, van Blitterswijk CA. Bone tissue engineering on amorphous carbonated apatite and crystalline octacalcium phosphate-coated titanium discs. Biomaterials 2005;26(25):5231-5239.

46. Barrere F, van der Valk CM, Dalmeijer RAJ, van Blitterswi$\mathrm{jk} \mathrm{CA}$, de Groot $\mathrm{K}$, Layrolle $\mathrm{P}$. In vitro and in vivo degradation of biomimetic octacalcium phosphate and carbonate apatite coatings on titanium implants. Journal of Biomedical Materials Research Part A 
$2003 ; 64 \mathrm{~A}(2): 378-387$.

47. Hanawa T, Kamiura Y, Yamamoto S, Kohgo T, Amemiya A, Ukai H, et al. Early bone formation around calcium-ion-implanted titanium inserted into rat tibia. J Biomed Mater Res 1997;36(1):131136.

48. Le Huec JC, Clement D, Brouillaud B, Barthe N, Dupuy B, Foliguet B, et al. Evolution of the local calcium content around irradiated beta-tricalcium phosphate ceramic implants: in vivo study in the rabbit. Biomaterials 1998;19(7-9):733-738.

49. Ducheyne P, Beight J, Cuckler J, Evans B, Radin S. Effect of Calcium-Phosphate Coating Characteristics on Early Postoperative Bone Tissue Ingrowth. Biomaterials 1990;11(8):531-540.

50. Moroni L, Schotel R, Hamann D, de Wijn JR, van Blitterswijk CA. 3D fibre-deposited electrospun integrated scaffolds enhance cartilage tissue formation. Advanced Functional Materials 2008;18(1):5360 .

51. Kuraishi K, Iwata H, Nakano S, Kubota S, Tonami H, Toda M, et al. Development of Nanofibre-Covered Stents Using Electrospinning: In Vitro and Acute Phase In Vivo Experiments. Journal of Biomedical Materials Research Part B-Applied Biomaterials 2009;88B(1):230239.

52. Moroni L, de Wijn JR, van Blitterswijk CA. 3D fibre-deposited scaffolds for tissue engineering: Influence of pores geometry and architecture on dynamic mechanical properties. Biomaterials 2006;27(7):974-985. 


\section{SUPPORTING INFORMATION}

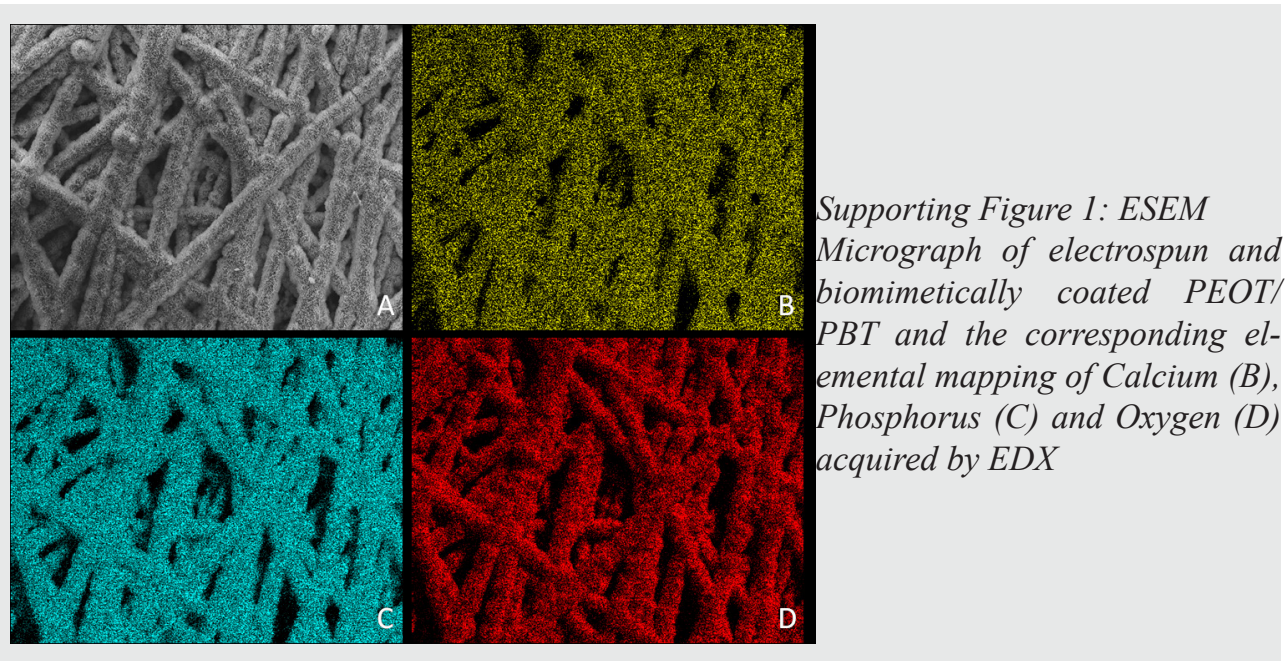




\title{
3
}

\section{Bioactive hierarchical scaffolds for bone tissue engineering}

\author{
Anandkumar Nandakumar, Ana Barradas, Jan de Boer, Lorenzo \\ Moroni, Clemens van Blitterswijk, Pamela Habibovic \\ Department of Tissue Regeneration, MIRA Institute for Biomedical \\ Technology and Technical Medicine, University of Twente, The Netherlands
}

If you are not failing every now and again, it is a sign you are not doing anything very innovative.

- Woody Allen 


\section{ABSTRACT}

Combining different technologies that can offer physical and chemical cues to cells is an attractive approach for engineering scaffolds. In this study, we have fabricated polymer-ceramic hybrid scaffolds for bone tissue engineering and regeneration by combining rapid prototyping (RP), electrospinning (ESP) and a biomimetic coating method in order to provide mechanical support and a physico-chemical environment mimicking both the organic and inorganic phases of bone extracellular matrix (ECM). Poly (ethylene oxide terephthalate) - poly (buthylene terephthalate) (PEOT/ $P B T)$ block copolymer was used to produce three dimensional scaffolds by combining $3 D$ fibre (3DF) deposition, and ESP, and these constructs were then coated with a Ca-P layer consisting of octacalcium phosphate (OCP) and carbonated apatite (CA) in a simulated physiological solution. Scaffold morphology and composition were studied using scanning electron microscopy (SEM) coupled to energy dispersive X-ray analyser (EDX) and Fourier Tranform Infrared Spectroscopy (FTIR). Human mesenchymal stromal cells (hMSCs) derived from the bone marrow were cultured on coated and uncoated $3 D F$ and $3 D F+E S P$ scaffolds for up to 21 days in basic and mineralisation medium and cell attachment, proliferation, and expression of genes related to osteogenesis were assessed. Cells attached, proliferated and secreted ECM on all the scaffolds. There were no significant differences in metabolic activity among the different groups on days 7 and 21. Coated 3DF scaffolds showed a significantly higher DNA amount in basic medium at 21 days compared to the coated $3 D F+E S P$ scaffolds, whereas in mineralisation medium, the presence of coating in $3 D F+E S P$ scaffolds led to a significant decrease in the amount of DNA. An effect of combining different scaffolding technologies and material types on expression of a number of osteogenic markers (cbfal, BMP-2, OP, OC and ON) was observed, suggesting the potential use of this approach in bone tissue engineering. 


\section{INTRODUCTION}

D apid Prototyping (RP) technologies are gaining importance as fabRrication techniques for preparation of $3 \mathrm{D}$ scaffolds used in various tissue engineering applications. The possibility to design and customise scaffold architecture and hence properties with a high degree of reproducibility has made RP a promising alternative to classical scaffolding technologies. Different RP techniques like fused deposition modelling [1], selective laser sintering [2] and stereolithography [3] have successfully been used for the fabrication of scaffolds for bone tissue engineering. RP scaffolds can be prepared from different materials like polymers, metals and composites [1, 4-5]. Using Computer Aided Design/Computer Aided Manufacturing (CAD/CAM) softwares, the mechanical properties [6] and pore sizes [7] can be controlled. It is also possible to fabricate anatomical shapes [8] by combining and integrating RP techniques with imaging techniques like CT scans, thus offering patient specific solutions.

While RP techniques can be used to create 3D scaffolds with sufficient mechanical strength by controlling overall geometrical design and porosity, they do not yet possess the resolution to fabricate nano- and sub-micrometre structures that can mimic the ECM of a cell. In this regard, ESP is gaining widespread attention. The possibility of creating an ECM- like milieu for cells to attach, grow and proliferate has been the main advantage of this method. High voltage is applied to a polymer solution or a melt to produce non woven fibre meshes in the nanometres to micrometres range that have been used as scaffolds and delivery vehicles [9-14]. The diameter and morphology of the mesh is influenced by the polymer - solvent system, concentration, flow, collector distance, voltage and ambient conditions like temperature and humidity [15-18].

In few studies, structurally hierarchical scaffolds (macro to nano level) for bone [19] and cartilage [20] tissue engineering applications have been fabricated. Such an approach ensures that a stable support structure is available through the RP compartment of the construct while the ECM-like mesh produced by ESP provides physical cues for the cells. The electrospun layer can also act as a sieve and entrap cells inside the scaffold thereby increasing seeding efficiency. 
Scaffolds for load-bearing applications in bone regeneration should be mechanically stable to provide mechanical support, as well as bioactive, facilitating or initiating proliferation and osteogenic differentiation of cells, ECM production and eventually bone deposition. As the inorganic component of bone is primarily composed of calcium-phosphate (Ca-P) in the form of biological apatite, incorporation of $\mathrm{Ca}-\mathrm{P}$ is another key aspect of scaffold fabrication for bone tissue engineering applications. Ca-P can be added to the bulk material to prepare composite scaffolds or it can be applied as a surface coating. Plasma spraying is the traditional coating method for coating hip implants with hydroxyapatite [21]. Although excellent clinical results were obtained [22], the process has limitations. The extremely high temperature makes it impossible to coat thermally unstable substrates like polymers or to incorporate biologically active molecules [23]. Plasma spraying only allows for the coating of thermodynamically stable phases and biologically relevant phases like OCP [24] and CA [25] cannot be coated by this method. The line-of-sight technique also poses limitations while coating of implants or substrates with complex geometrical shapes [26]. Research has led to the development of several other Ca-P coating processes to overcome the limitations of plasma spraying. Among them, biomimetic coating methods involving the immersion of the substrate into solutions simulating physiological fluids are very attractive as the process takes place at near-physiological $\mathrm{pH}$ and temperatures, allowing coating of complex and thermally unstable substrates and the incorporation of proteins and growth factors [27-28]. Kokubo et al. [29] developed simulated body fluid (SBF), a solution resembling human blood plasma, in order to study the ability of biomaterials to mineralise in vitro. Based on this, Barrere et al. [30] developed a twostep procedure using a supersaturated solution of SBF ( $\mathrm{SBF} \times 5)$ to coat biomaterial surfaces with a Ca-P layer. Recently, Oliviera and coworkers [31] used sodium silicate as a nucleating agent and deposited a biomimetic apatite coating on starch-polycaprolactone (PCL) based 3D scaffolds using static and dynamic conditions. Arafat et al. [32] deposited a CA coating in combination with gelatin on PCL/tricalcium phosphate (TCP) 3-D scaffolds prepared by a screw extrusion system.

In order to create scaffolds that encompass the required physical and chemical cues for bone tissue engineering applications, in the present study, we combined different technologies, each of which should add 
a new dimension to the resulting scaffolds. To this end, we used $3 \mathrm{DF}$ to create a mechanically stable structure, ESP to provide a random mesh mimicking the ECM and a Ca-P coating to increase bioactivity of polymer used to build the scaffolds. We used a PEOT/PBT block co-

Figure 1: A schematic illustration of the different technologies involved in fabricating the hybrid scaffolds used in this study. (A) 3-D fibre deposition (3DF) enables a controlled layer by layer deposition of extruded polymer, (B) Electrospinning to produce extra-cellular matrix like fibres and $(C)$ Biomimetic calcium phosphate coating to enhance osteoconduction of the scaffolds

polymer, commercially sold under the name PolyActive ${ }^{\mathrm{TM}}$ (PA), with tunable properties that has been used for various bone [33], cartilage [34] and osteo-chondral [35] tissue engineering applications before. The biological performance of the hybrid scaffolds developed here was evaluated in vitro by culturing hMSCs and analysing attachment, metabolic activity and gene expression levels for osteogenic markers.

\section{MATERIALS AND METHODS}

DolyActive ${ }^{\mathrm{TM}}$ (PA) was provided by PolyVation BV, The Nether1 lands. Following an aPEOTbPBTc nomenclature, the composition used in this study was 300PEOT55PBT45 where, (a) is the molecular weight in $\mathrm{g} / \mathrm{mol}$ of the starting poly(ethylene glycol) (PEG) blocks used in the copolymerisation, while (b) and (c) are the weight ratios of the PEOT and PBT blocks, respectively. All the salts and reagents 
used for the preparation of the coating were purchased at either Merck or Sigma-Aldrich.

\section{FABRICATION OF 3DF SCAFFOLDS}

3D scaffolds were fabricated by 3DF using a Bioplotter. The Bioplotter (Envisiontec GmbH, Germany) is an XYZ plotter device as previously described [36]. Briefly, polymer granules were loaded onto a stainless steel syringe and heated at $195^{\circ} \mathrm{C}$ using a thermostat controlled cartridge unit, fixed on the "X"-mobile arm of the apparatus. A pressure of 4 bars (nitrogen) was applied to the syringe through a pressurised cap once the polymer had melted. Rectangular block models were loaded on the Bioplotter CAM (PrimCAM, Switzerland) software and deposited layer by layer as the polymer was extruded through a nozzle $(0.7 \mathrm{~mm} \mathrm{OD})$ on a stage. The deposition speed was varied between 200 $-300 \mathrm{~mm} / \mathrm{min}$. The spacing between fibres in the same layer was set at $0.8 \mathrm{~mm}$ and the layer thickness was $0.225 \mathrm{~mm}$. A $0-90^{\circ}$ configuration was used for scaffold architecture where fibres were deposited with $90^{\circ}$ orientation steps between successive layers.

\section{DEPOSITION OF ELECTROSPUN FIBRES ONTO 3DF SCAFFOLDS}

PA was dissolved in a mixture of chloroform - hexafluoroisopropanol (HFIP) (78\%-22\%v/v) respectively. A 28\% (w/v) PEOT/PBT solution in chloroform - HFIP were prepared and stirred overnight at room temperature. The solution was loaded into a syringe and the flow rate was controlled using a syringe pump (KDS 100, KD Scientific). The other end of the syringe was connected to a needle, on which a positive high voltage was applied using a high voltage generator (Gamma High Voltage Research Inc., USA). A metallic sheet of stainless steel was the collector (ground). An electrostatic field was formed between the needle and the collector when the generator was turned on. The polymer solution was pushed through the syringe to the tip of the needle. When the electrostatic field strength overcame the surface tension of the liquid drop at the tip of the needle, the drop was stretched into fibres and deposited onto the $3 \mathrm{DF}$ scaffold placed on the collector. A flow rate of $15 \mathrm{~mL} / \mathrm{hr}$, distance of $15 \mathrm{~cm}$ and voltage of $12 \mathrm{kV}$ were used for the spinning and fibres were deposited for 30 seconds on the collector. 
This process was repeated at $0.9 \mathrm{~mm}, 2.025 \mathrm{~mm}$ and $2.925 \mathrm{~mm}$ of $3 \mathrm{DF}$ scaffold height to create 3 DF-ESP scaffolds. Temperature and humidity were monitored during the process and ranged between 19.6 - 20.4 ${ }^{\circ} \mathrm{C}$ and $33-42 \%$ respectively.

\section{PREPARATION OF BIOMIMETIC CA-P COATINGS ON SCAFFOLDS}

3DF and 3DF-ESP scaffolds were punched to cylinders $(5 \mathrm{~mm}$ diameter, $4 \mathrm{~mm}$ height) and coated with Ca-P using a two-step coating process. In the first step, a five times concentrated simulated body fluid solution ( $\mathrm{SBFx} 5)$ was prepared by dissolving reagent grade $\mathrm{NaCl}$ (40 g), $\mathrm{CaCl}_{2} \cdot 2 \mathrm{H}_{2} \mathrm{O}(1.84 \mathrm{~g}), \mathrm{MgCl}_{2} \cdot 6 \mathrm{H}_{2} \mathrm{O}(1.52 \mathrm{~g}), \mathrm{NaHCO}_{3}(1.76 \mathrm{~g})$ and $\mathrm{Na}_{2} \mathrm{HPO}_{4} \cdot 2 \mathrm{H}_{2} \mathrm{O}(0.89 \mathrm{~g})$ salts in 11 of demineralised water at $37^{\circ} \mathrm{C}$ under $\mathrm{CO}_{2}$ gas bubbling. The $\mathrm{CO}_{2}$ source was then removed from the solution and the $3 \mathrm{DF}$ and $3 \mathrm{DF}-\mathrm{ESP}$ scaffolds were immersed in the solution in a partly open vial and left to coat for 24 hours under continuous gentle stirring at $37^{\circ} \mathrm{C}$. This process was previously shown to result in a formation of thin, amorphous calcium-phosphate layer.

In the second step, scaffolds pre-coated in step 1 were immersed in a calcium phosphate solution (CPS) at physiological $\mathrm{pH}$ of 7.4 and temperature of $37^{\circ} \mathrm{C}$ for 24 hours to deposit a crystalline layer onto previously formed amorphous Ca-P layer. CPS was prepared by dissolving $\mathrm{NaCl}(8 \mathrm{~g}), \mathrm{CaCl}_{2} .2 \mathrm{H}_{2} \mathrm{O}(0.59 \mathrm{~g}), \mathrm{Na}_{2} \mathrm{HPO}_{4} \cdot \mathrm{H}_{2} \mathrm{O}(0.36 \mathrm{~g})$ and Tris (6.05 $\mathrm{g}$ ) in MilliQ water and the $\mathrm{pH}$ of the solution was adjusted to 7.4 with $1 \mathrm{M} \mathrm{HCl}$. The coated scaffolds were thoroughly washed in MilliQ water and dried overnight at $50^{\circ} \mathrm{C}$.

\section{CHARACTERISATION OF SCAFFOLDS}

The architecture and composition of the different types of scaffolds were characterised using Environmental SEM in secondary electron mode coupled to EDX analyser (XL 30 ESEM - FEG, Philips). FTIR spectroscopy (Perkin Elmer Spectrum 1000) was performed on the coatings which were obtained by scratching the coated scaffolds. Fibre diameters were calculated from SEM micrographs using Image J (National Institutes of Health, Bethesda, MD, USA). 


\section{HMSC ISOLATION AND CELL SEEDING}

Bone marrow aspirates were obtained after written informed consent, and hMSCs were isolated and proliferated as described previously [37]. Briefly, aspirates were resuspended by using 20 -gauge needles, plated at a density of $5 \times 10^{5}$ cells $/ \mathrm{cm}^{2}$ and cultured in hMSC proliferation medium containing $\alpha$-minimal essential medium (Life Technologies), $10 \%$ foetal bovine serum (Cambrex), $0.2 \mathrm{mM}$ ascorbic acid (Asap; Life Technologies), $2 \mathrm{mM} \mathrm{L-glutamine} \mathrm{(Life} \mathrm{Technologies),}$ 100 units $/ \mathrm{ml}$ penicillin (Life Technologies), $10 \mu \mathrm{g} / \mathrm{ml}$ streptomycin (Life Technologies), and $1 \mathrm{ng} / \mathrm{ml}$ basic fibroblast growth factor (FGF) (Instruchemie). Cells were grown at $37^{\circ} \mathrm{C}$ in a humid atmosphere with $5 \% \mathrm{CO}_{2}$. Medium was refreshed twice a week, and cells were used for further sub-culturing or cryopreservation. The hMSC basic medium was composed of hMSC proliferation medium without basic FGF. Mineralisation medium was composed of hMSC basic medium with supplemented with $10^{-8} \mathrm{M}$ dexamethasone (Sigma, St. Louis, MO) and 0.01M $\beta$-glycerophosphate (BGP; Sigma). Cells were trypsinised prior to seeding on scaffolds.

The in vitro experiments were performed with cells from one donor at passage 3. Cylinders ( $5 \mathrm{~mm}$ diameter, $4 \mathrm{~mm}$ height) of the four types of scaffolds (3DF, 3DF + coating, 3DF + ESP and 3DF + ESP + coating) were soaked in $100 \%$ ethanol for 30 minutes and dried overnight in a laminar flow cabinet. The scaffolds were washed twice with sterile PBS, transferred to a 25 well non-treated polystyrene plate (Greiner Bio One) and incubated at $37^{\circ} \mathrm{C}$ in a humid atmosphere with $5 \% \mathrm{CO} 2$ for four hours in basic cell culture medium. After removing the medium, each scaffold was seeded with 700,000 cells approximately for PCR analysis and 500,000 cells for Alamar blue and DNA assay in 80 $\mu 1$ basic medium. The cell-scaffold constructs were incubated for three hours to allow cell attachment and topped up to $2 \mathrm{ml}$ with appropriate media. Scaffolds were cultured either in basic media or mineralisation media and medium was refreshed twice a week. As a control, T- 25 flasks were seeded at $5000 \mathrm{cells} / \mathrm{cm}^{2}$ in basic and mineralisation medium. 
ALAMAR BLUE ASSAY FOR CELL METABOLISM

Metabolism was assessed using Alamar blue assay according to the manufacturer's protocol. Briefly, culture medium was replaced with medium containing 10\% (v/v) Alamar blue solution (Biosource, Camarillo, CA, USA) and the cells were incubated at $37^{\circ} \mathrm{C}$ for 4 hours. Fluorescence was measured at $590 \mathrm{~nm}$ on a Perkin Elmer Victor ${ }^{3} 1420$ Multilabel plate reader. Metabolism was analysed on day 7 and 21 and the readout from the scaffolds was corrected with the blank from each group and normalised to scaffold weight.

\section{DNA ASSAY}

Scaffolds were washed with PBS and frozen at $-80^{\circ} \mathrm{C}$ overnight. The constructs were then digested at $56{ }^{\circ} \mathrm{C}$ in a Tris-EDTA buffered solution containing $1 \mathrm{mg} / \mathrm{ml}$ proteinase $\mathrm{K}, 18.5 \mu \mathrm{g} / \mathrm{ml}$ pepstatin $\mathrm{A}$ and $1 \mu \mathrm{g} / \mathrm{ml}$ iodoacetamide (Sigma-Aldrich) for 18 hours. Cell numbers were determined using the CyQUANT ${ }^{\circledR}$ DNA quantification kit (Invitrogen) with $50 \mu \mathrm{l}$ of cell lysate according to the manufacturer's protocol. Fluorescence at an excitation wavelength of $480 \mathrm{~nm}$ and an emission wavelength of $520 \mathrm{~nm}$ was measured using a Perkin Elmer Victor ${ }^{3}$ 1420 Multilabel plate reader and total amount of DNA was normalised to scaffold weight.

\section{CELl MORPhOlOGY USing SEM}

On day 21, one sample from each group was used for SEM analysis. The medium was removed and the scaffolds were washed twice with PBS and fixed in 10\% formalin for one hour. After rinsing with PBS, the scaffolds were dehydrated in a series of increasing ethanol concentrations $(70 \%, 80 \%, 90 \%, 96 \%, 100 \% \times 2), 15$ minutes in each concentration, before being dried in a critical point dryer (Balzers CPD-030). The samples were then sputter coated with gold (Cressington) for observation on the SEM. 
RNA ISOLATION AND GENE EXPRESSION ANALYSIS USING QUANTITATIVE PCR

To analyse the expression of osteogenic markers by hMSCs, total RNA was isolated using a combination of the TRIzol ${ }^{\circledR}$ method with the NucleoSpin $^{\circledR}$ RNA II isolation kit (Macherey-Nagel). Briefly, scaffolds were washed with PBS once and $1 \mathrm{ml}$ of TRIzol reagent (Invitrogen) was added to the samples. After one freeze/thaw cylcle, chloroform was added, followed by phase separation by centrifugation, the aqueous phase containing the RNA was collected, mixed with equal volume of $75 \%$ ethanol and loaded onto the RNA binding column of the kit. Subsequent steps were in accordance with the manufacturer's protocol. RNA was collected in RNAse-free water. The quality and quantity of RNA was analysed by gel electrophoresis and spectrophotometry. Three hundred ng of RNA were used for first strand cDNA synthesis using iScript (Bio-Rad) according to the manufacturer's protocol. One $\mu$ l of undiluted cDNA was used for subsequent analysis. PCR was performed on a Light Cycler real time PCR machine (Roche) using SYBR green I master mix (Invitrogen). Data was analysed using Light Cycler software version 3.5.3, using the fit point method by setting the noise band to the exponential phase of the reaction to exclude background fluorescence. Expression of osteogenic marker genes was normalised to GAPDH (5'- CGCTCTCTGCTCCTCCTGTT- 3' and 5'-CCATGGTGTCTGAGCGATGT -3')) levels and fold inductions were calculated using the comparative $\Delta \mathrm{CT}$ method [27]. The following primer sequences were used for the osteogenic marker genes: Osteocalcin (OC) (5'-GGCAGCGAGGTAGTGAAGAG-3' and 5'-GATGTGGTCAGCCAACTCGT-3'), Bone Sialoprotein (BSP) (5' '-TGCCTTGAGCCTGCTTCC-3' and 5'-CAAAATTAAAGCAGTCTTCATTTTG-3'), Runt-related Transcription Factor-2 (RUNX2/cbfa-1) (5'-GGAGTGGACGAGGCAAGAGTTT-3' and 5'-AGCTTCTGTCTGTGCCTTCTGG- 3'), Collagen type 1 (5'-AGGGCCAAGACGAAGACATC-3' and 5' - AGATCACGTCATCGCACAACA-3'), Osteopontin (OP) (5'-CCAAGTAAGTCCAACGAAAG-3 and 5'-GGTGATGTCCTCGTCTGTA-3'), Osteonectin (ON) (5'-ACTGGCTCAAGAACGTCCTG-3' and 5'-GAGAGAATCCGGTACTGTGG-3'), and Alkaline Phosphatase (ALP) (5'-GACCCTTGACCCCCACAAT-3' and 5'-GCTCGTACTGCATGTCCCCT-3'). For 
amplification of Bone Morphogenetic Protein-2 (BMP-2), a gene-specific primer mix was used (SA Biosciences), according to the manufacturer's protocol.

\section{STATISTICAL ANALYSIS}

One way ANOVA with Tukey's multiple comparison post-hoc test was performed. The level of significance was set at 0.05 . All data presented are expressed as mean \pm standard deviation. Only significant differences due to the effect of coating and presence of electrospun fibres have been shown.

\section{RESULTS}

\section{FABRICATION AND CHARACTERISATION OF SCAFFOLDS}

schematic of the fabrication methodology used to produce coated
and uncoated $3 \mathrm{DF}$ and $3 \mathrm{DF}+$ ESP scaffolds is shown in figure 1. Fibre diameter of the scaffolds was calculated to be $249 \pm 21 \mu \mathrm{m}$. Fibre spacing and layer thickness were $830 \pm 40 \mu \mathrm{m}$ and $246 \pm 22 \mu \mathrm{m}$,

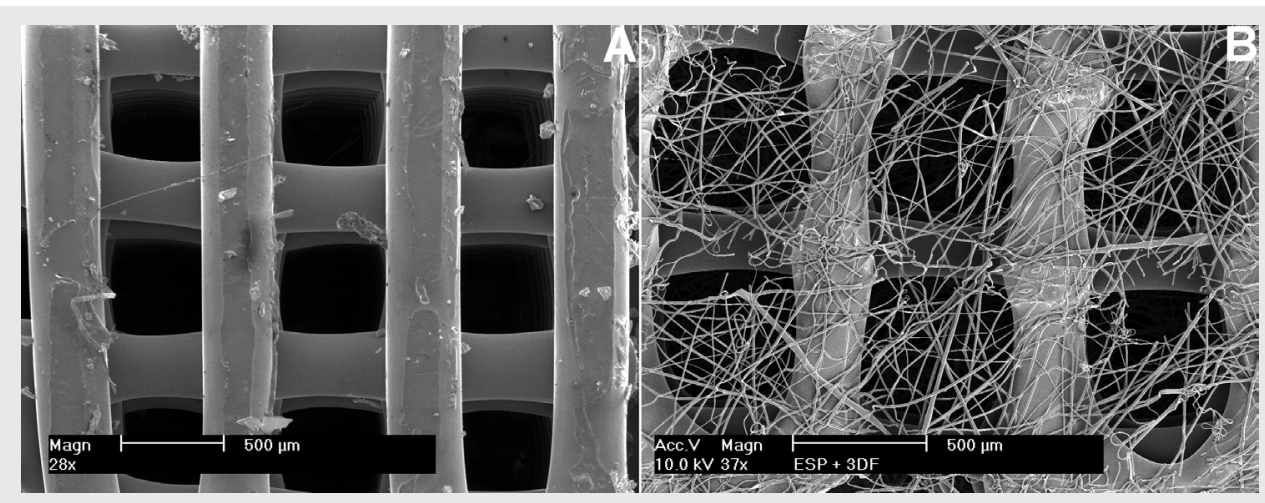

Figure 2: Scaffold morphology using SEM. (A) 3DF scaffold prepared by rapid prototyping. (B) $3 D F+E S P$ scaffold prepared by combining rapid prototyping and electrospinning. The scaffold has been "opened" to enable visualisation of the electrospun fibre meshes. Scale bar $=500 \mu \mathrm{m}$

respectively and these values are in close agreement with the input set- 
tings during fabrication. Electrospun meshes consisted of fibres with a diameter of $5.1 \pm 0.94 \mu \mathrm{m}$. Figure $2 \mathrm{~A}$ shows a $3 \mathrm{DF}$ scaffold while 2B shows an "open" 3DF + ESP scaffold to visualise the concept of

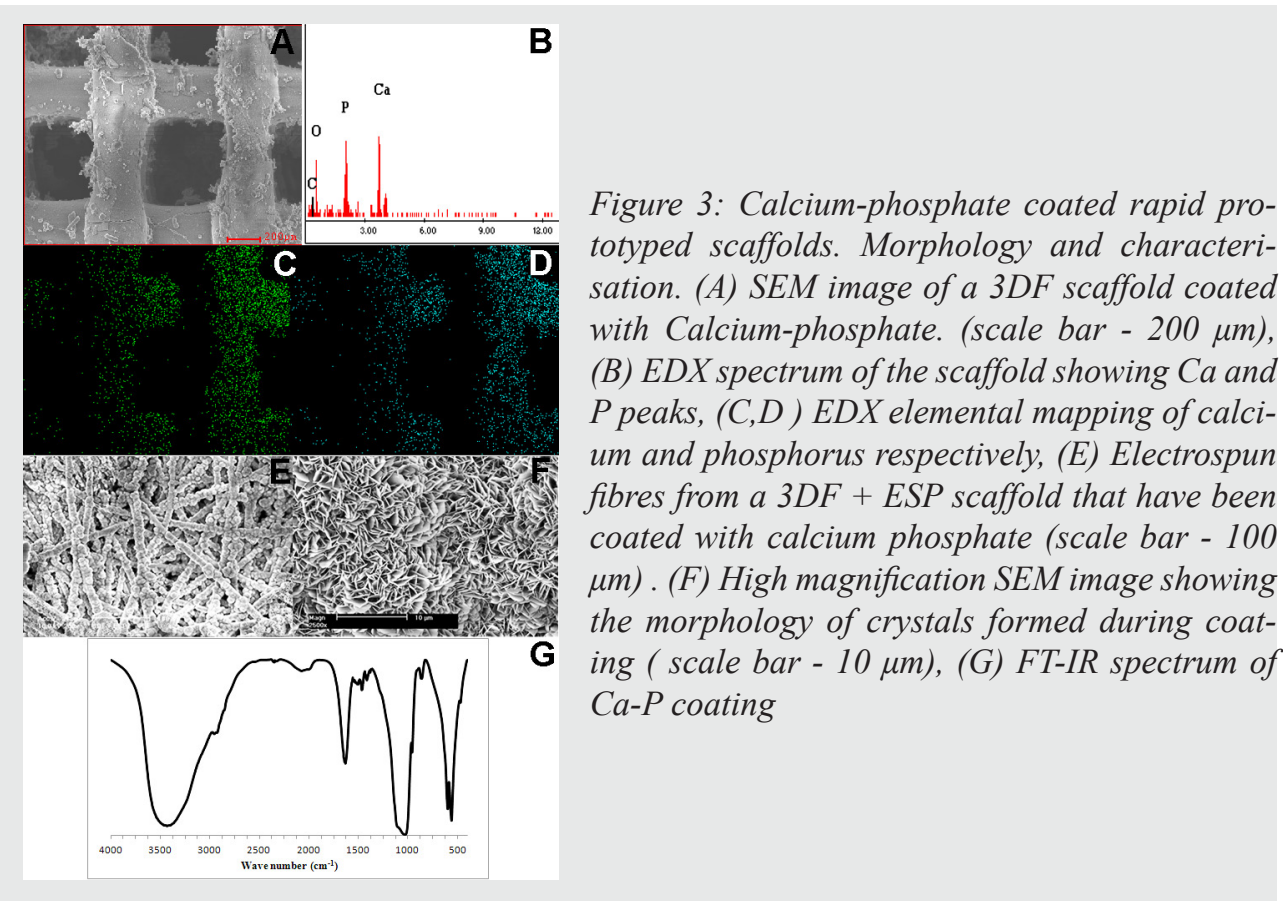

combining the two technologies. 3DF and 3DF + ESP scaffolds were coated with calcium phosphate under physiological conditions. The morphology of the coating, EDX spectrum and mapping for calcium and phosphorus and the FT-IR spectrum are presented in figure 3 . The SEM images along with the EDX mapping show that the coating homogenously covered the surface of the 3DF scaffolds (Figure 3A-D). Figure $3 \mathrm{E}$ shows a homogenous distribution of the $\mathrm{Ca}-\mathrm{P}$ coating on electrospun fibres of the scaffold. The coating consisted of plate-like crystals, with a size of 1-2 $\mu \mathrm{m}$, orientation of which was perpendicular to the surface of the fibres (Figure 3F). FT - IR spectrum of the Ca-P coating indicates mainly an OCP phase with some carbonated apatite. Typical P-O bands were observed at 562.5 and $602 \mathrm{~cm}^{-1}$. In an earlier study by $\mathrm{Du}$ et al. [38] on similar calcium phosphate coatings deposited on PA the bands at 1104,1041 and $960 \mathrm{~cm}^{-1}$ were assigned to P-O stretching in $\mathrm{PO}_{4}$ and $\mathrm{HPO}_{4}$ group. In the current spectrum, the 1104 
and 1041 appear to have shifted to 1114 and $1040 \mathrm{~cm}^{-1}$ while the 960 $\mathrm{cm}^{-1}$ band was consistent. Du. et al. also identified carbonate incorporation by bands at $1467,1454,1413$ and $873 \mathrm{~cm}^{-1}$ whereas in the current study, carbonate bands were observed at 1420,1468 and $870 \mathrm{~cm}^{-1}$.

\section{METABOLISM AND CELL NUMBERS}

Alamar blue assay was used to determine the metabolic activity of cells seeded on the different scaffolds. As seen in figure 4, no significant differences were observed between cells seeded on different scaffolds and in different media over time.

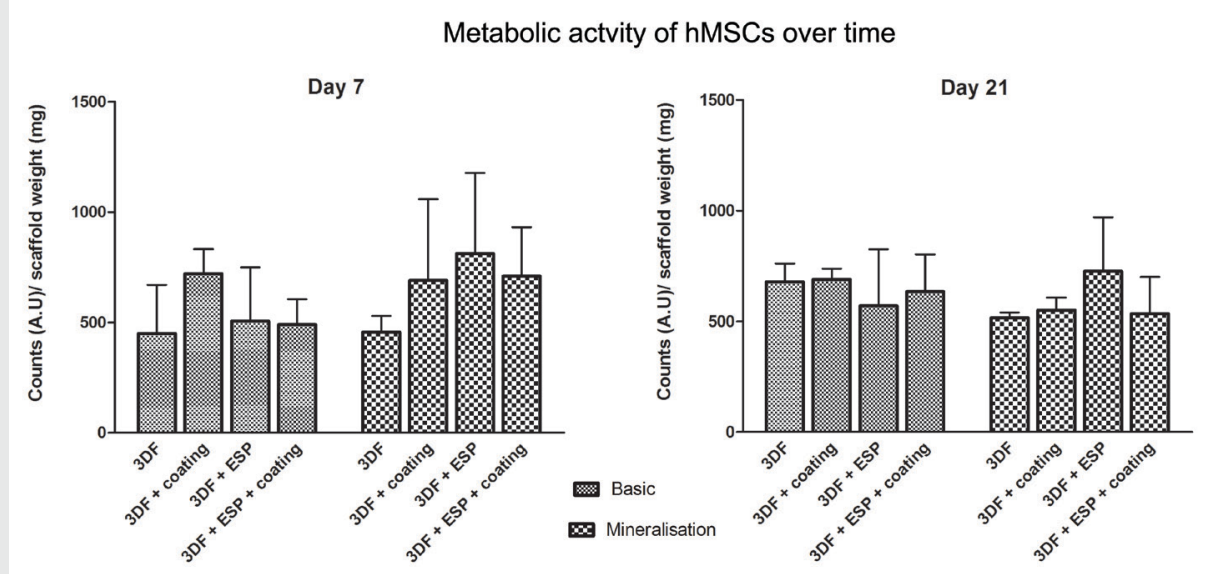

Figure 4: Metabolic activity of cells seeded on different scaffolds in basic and mineralisation medium on days 7 and 21 measured using Alamar Blue assay. Data are represented as mean \pm standard deviation

On day 21, the amount of DNA present in the scaffolds was analysed (Figure 5). No significant differences due to the culture media were observed. However the presence of electrospun fibres and coatings had a significant effect on the amount of DNA. When coated scaffolds were compared in basic medium, the presence of electrospun fibres reduced the amount of DNA significantly $(3 \mathrm{DF}+\mathrm{ESP}+$ coating $<3 \mathrm{DF}$ + coating). In mineralisation medium, the presence of coating had a significant effect on the $3 \mathrm{DF}+\mathrm{ESP}$ scaffolds. Uncoated $3 \mathrm{DF}+\mathrm{ESP}$ scaffolds had significantly higher DNA amounts compared to coated scaffolds of the same type. 


\section{Cell morphology USing SEM}

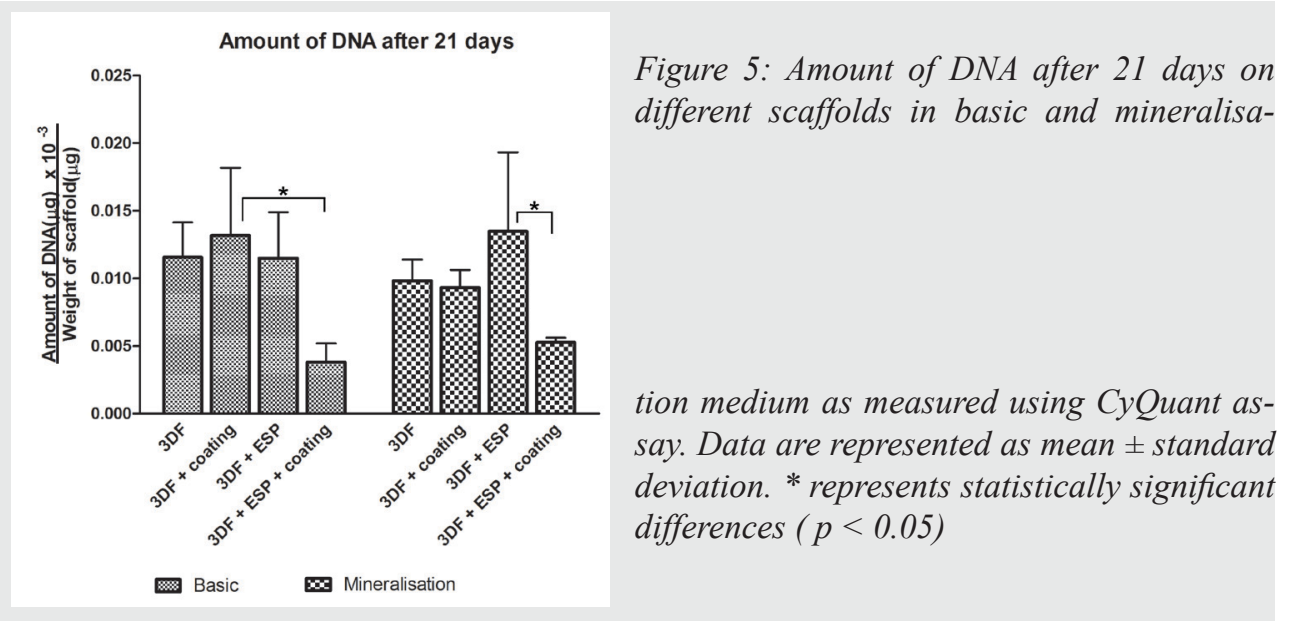

Figure 6 shows SEM images of cell-scaffold constructs cultured in basic medium at 21 days. From the images, it can be observed that cells penetrated into the scaffolds. The retention of cells by the electrospun mesh and the preferential attachment of cells to the fibres compared to the struts of the $3 \mathrm{D}$ scaffold can be seen in figure $6 \mathrm{c}$. An open ESP $+3 \mathrm{DF}$ scaffold is shown in the inset in $\mathrm{C}$ and a cell layer covering the electrospun mesh can be observed. The white arrow points to electrospun fibres. Figures 6e and $6 \mathrm{f}$ show the attachment of hMSCs on calcium-phosphate coatings and on electrospun fibres respectively with arrows pointing to calcium phosphate particles and electrospun fibres.

\section{GENE EXPRESSION ANALYSIS USING QUANTITATIVE PCR}

The expression of cbfa1, BSP, ALP, BMP-2, OC, ON, OP and Col -I as markers of osteogenic differentiation was analysed on days 7 and 21 to evaluate the osteogenic potential of the different scaffolds. The fold induction was calculated relative to the expression of the genes on the $3 \mathrm{DF}$ scaffold in basic medium. The effect of Ca-P coating and electrospun fibres in each medium was analysed.

\section{EFFECT OF CA-P COATING}

On day 7, significant upregulation of BMP-2 expression was observed in both coated scaffolds in basic medium. OP expression was upregu- 
lated in both coated scaffolds (basic medium) and this was significant in the 3DF+ESP scaffold group. In mineralisation medium, the Ca-P coating significantly downregulated the expression of ALP, BSP and

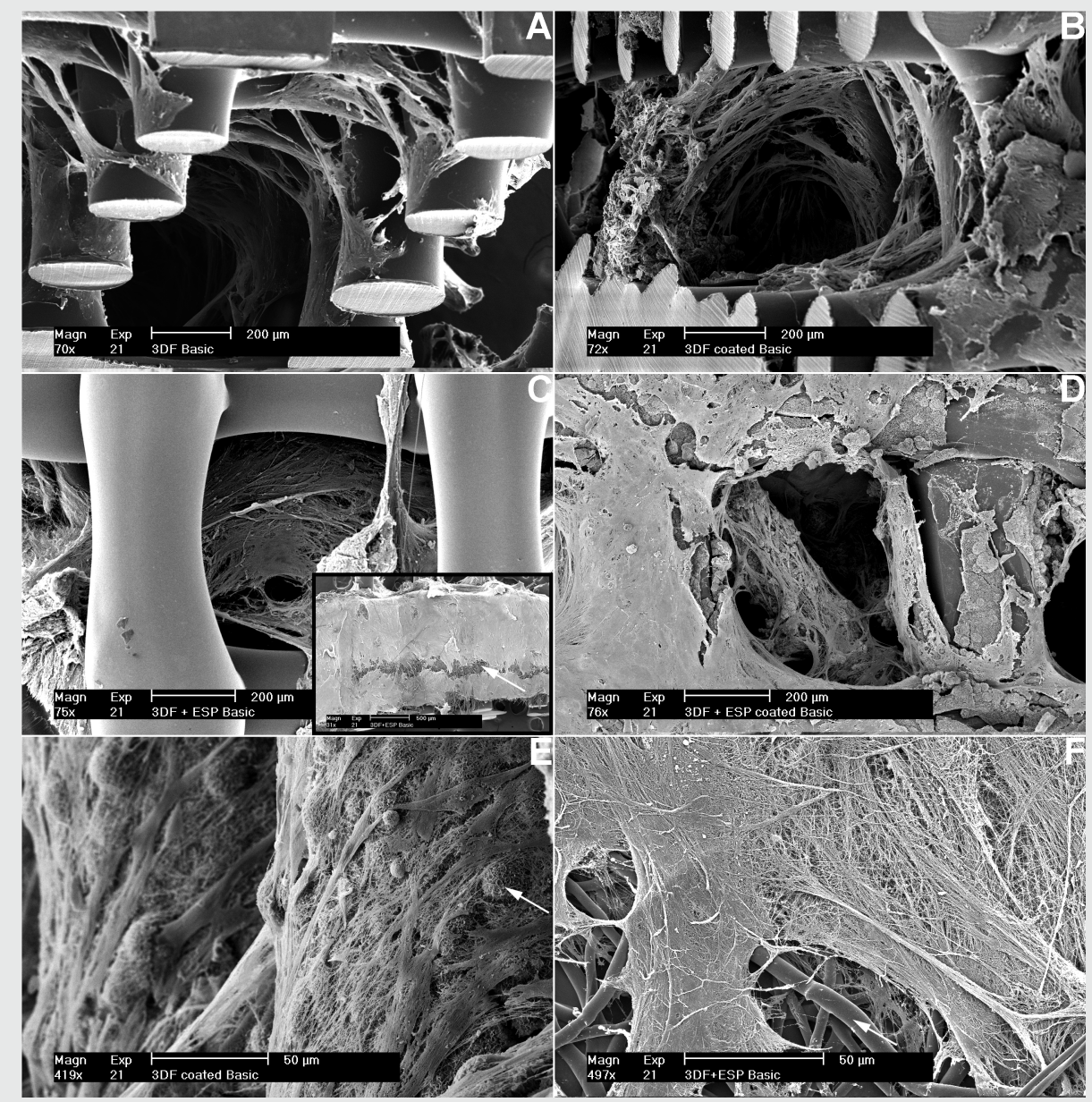

Figure 6: Cell morphology on scaffolds after 21 days. (A-D) represent 3DF (uncoated and coated) and $3 D F+E S P$ (uncoated and coated scaffolds) in basic medium. Inset in C shows hMSCs on the electrospun layer (indicated by white arrow). (E) Higher magnification image of hMSCs attaching calcium-phosphate coatings. White arrow indicates coating. (F) Higher magnification image of hMSCs on electrospun fibres (white arrow). Scale bars $A-D-200 \mu m$, Inset in $C-500 \mu \mathrm{m}, E$ and $F-50 \mu m$

OC in $3 \mathrm{DF}$ coated scaffolds, while $3 \mathrm{DF}+\mathrm{ESP}$ coated scaffolds in ba- 


\section{Expression of osteogenic markers on day 7}
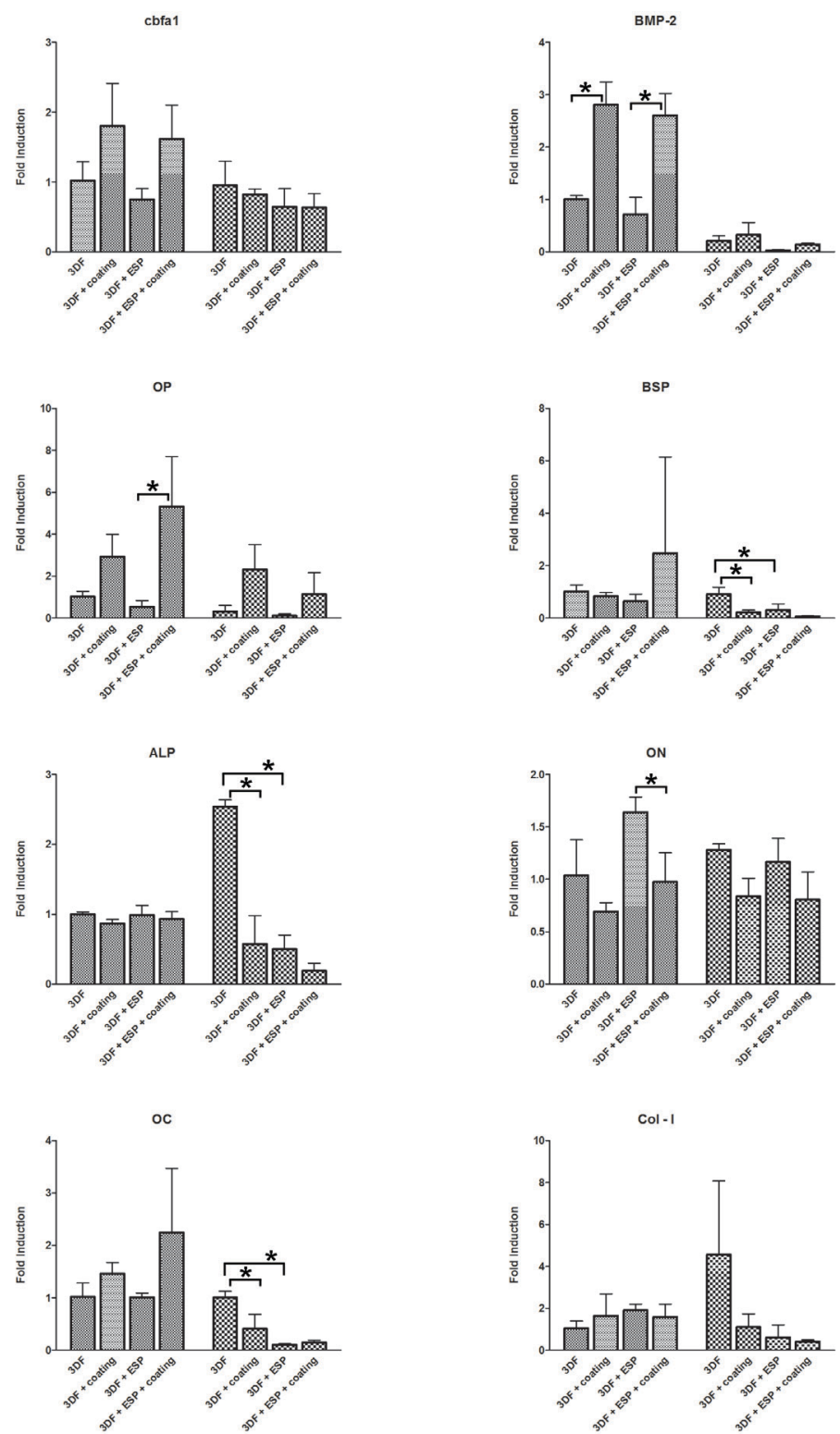

Dasic

Mineralisation

Figure 7: qPCR analysis for osteogenic panel of genes after 7 days in culture. * represents $p$ $<0.05$. Data are represented as mean \pm standard deviation 


\section{Expression of osteogenic markers on day 21}
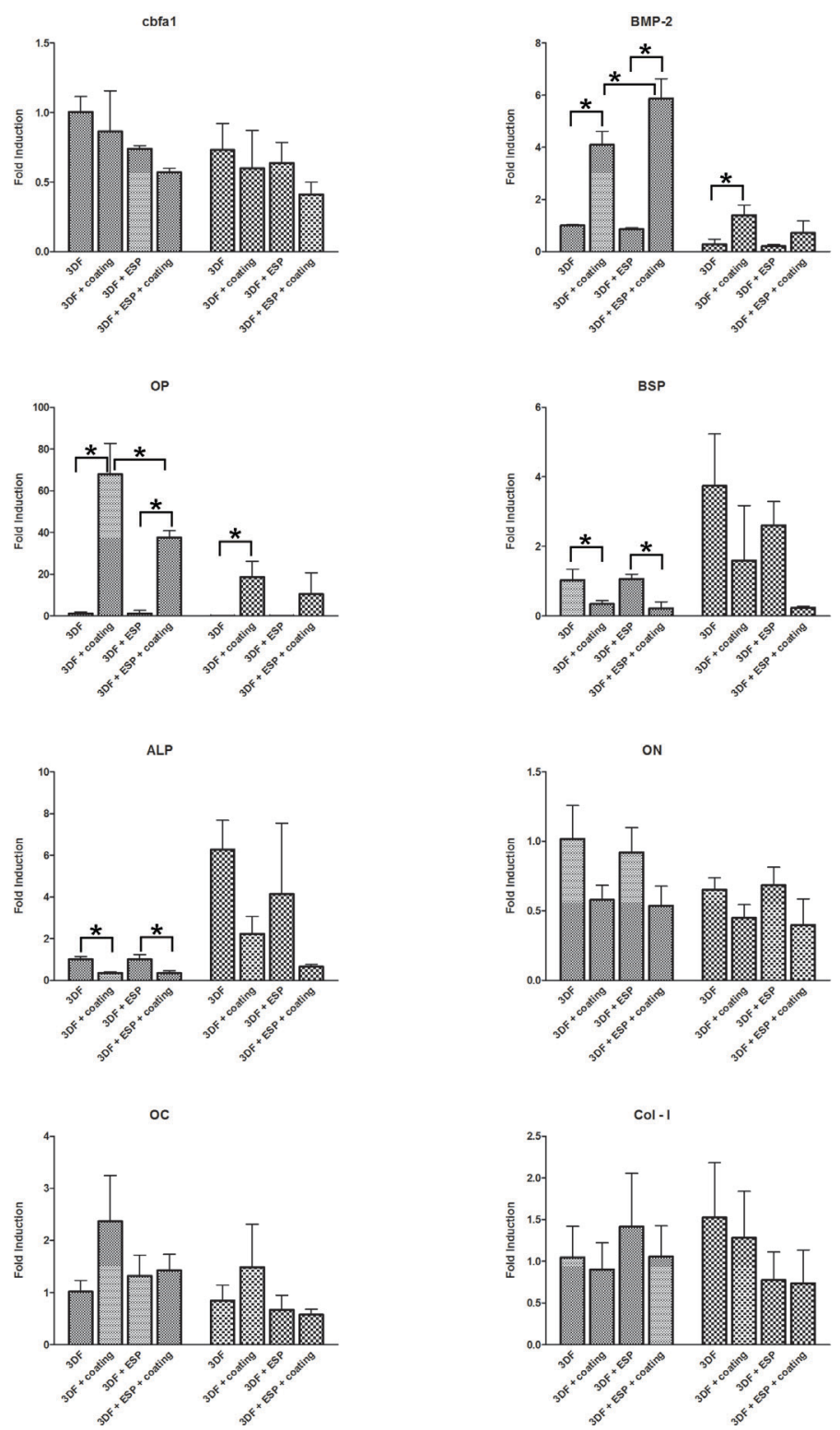

Dasic

Mineralisation

Figure 8: qPCR analysis for osteogenic panel of genes after 21 days in culture. * represents $p<0.05$. Data are represented as mean \pm standard deviation 
sic medium had a significantly lower expression of ON compared to 3DF+ESP scaffolds.

On day 21, significant upregulation of BMP-2 and OP was again observed in 3DF coated (basic and mineralisation) and 3DF + ESP coated (basic) scaffolds. OP expression showed nearly 40 and 70 fold induction in coated scaffolds with and without electrospun fibres respectively. Significant downregulation of BSP and ALP expression due to the presence of coating was observed for both sets of coated scaffolds in basic medium.

\section{EFFECT OF ELECTROSPUN FIBRES}

On day 7, the presence of electrospun fibres led to a significant downregulation in the expression of BSP, ALP and OC in mineralisation medium while no significant differences in gene expression of osteogenic markers was observed in the basic medium. On day 21, statistically significant differences in gene expression were observed only for BMP-2 and OP in basic medium. In the presence of Ca-P coating, a positive effect of the electrospun mesh was observed in the case of BMP-2 whereas the addition of an electrospun mesh led to a significantly lower expression of OP. No differences due to the presence of an electrospun mesh were observed in mineralisation medium.

\section{DISCUSSION}

$\mathbf{P}$ in the form of $3 \mathrm{DF}$ was combined with ESP and Ca-P coatings R to successfully fabricate hybrid scaffolds for use in bone tissue engineering. Although 3DF and ESP based scaffolds have been separately used for tissue engineering applications, we hypothesised that a combination or merger of these two technologies would lead to improved scaffold properties at different scales. While 3DF scaffolds can provide the necessary mechanical stability $[6,39]$ and support in compression, the electrospun scaffolds serve to mimic the fibrillar nature of ECM and electrospun fibres generally provide a suitable surface for cell attachment. The combination of 3DF and ESP has already shown enhanced cellular response in terms of cell numbers and increased ALP or GAG production when used as a scaffold for bone [19] and cartilage [20] tissue engineering respectively. In an earlier study [40], we demonstrated the in vivo bone forming ability of Ca-P coated electros- 
pun scaffolds in combination with goat MSCs in a subcutaneous nude mouse model and hence decided to add another layer of functionality to the scaffolds by coating them with $\mathrm{Ca}-\mathrm{P}$, thereby providing chemical cues for differentiation. By using biomimetic method based on immersion in an aqueous solution of inorganic salts at near-physiological conditions, we succeeded in homogenously coating both 3DF and $3 \mathrm{DF}+\mathrm{ESP}$ scaffolds with a layer of Ca-P, that was a mixture of OCP and $\mathrm{CA}$, which are considered precursor and end phase of mineral part of bone [24, 41-42] respectively.

All scaffolds allowed the adhesion and proliferation of hMSCs, and at 21 days, ECM production was observed inside the scaffolds. No effect of either ESP mesh or Ca-P coating was found on cell proliferation; however, cell number at 21 days, expressed in terms of total DNA amount, was lower in coated scaffolds containing ESP mesh than in coated 3DF scaffolds. Similarly, in mineralisation medium, uncoated $3 \mathrm{DF}+\mathrm{ESP}$ scaffolds had the highest amount of DNA after 21 days and this amount was significantly higher than that observed in the Ca-P coated 3DF+ESP scaffolds. A possible reason for a significant decrease in DNA amounts in presence of electrospun fibres in the coated scaffolds could be that, after coating, the pore size of the electrospun meshes decreases to a size whereby the cells are trapped in the first electrospun layer at the periphery of the scaffold. Although in this study we did not measure the thickness of the coating, previous studies [43] using electrospun fibres of the same polymer and fibre diameter have shown that this type of coating can reach a thickness of approximately $15 \mu \mathrm{m}$. Considering that the pore size between the ESP fibres is about $40 \mu \mathrm{m}$, it is indeed possible that the coating has "clogged" the mesh. Decreasing the initial fibre density by reducing the spinning time is a way of obtaining a less dense ESP mesh, which, in this case, would improve interconnectivity of pores throughout the scaffold, thus even through the ESP mesh. Hence, in this study, the hypothesised benefit of the entrapment of cells inside the ESP mesh was not directly visible, particularly when the scaffolds were coated with ESP. In previous studies where RP and ESP technologies were integrated [19-20] for tissue engineering applications, a higher ratio of electrospun to RP layers (1 ESP layer for per 2 RP layers) was used than in the current study (1 ESP layer every 4 RP layers). In those studies, cell numbers were also lower in hybrid than in RP scaffolds alone, which in the case 
of the study with bovine chondrocytes, was explained by the initiation of chondrogenic differentiation of cells. Cell differentiation as a cause of a decrease in cell proliferation was not observed in the present study. Another study that combined RP and ESP showed significant differences in porcine chondrocyte proliferation up to 4 days due to the presence of the electrospun mesh but no difference after 7 days, which was attributed to saturation in cell proliferation within the scaffold [44]. For an optimal configuration that ensures significant cell retention without closure of pores due to the coating, it is suggested to increase the number of electrospun layers while decreasing their density.

The effect of Ca-P coating on cell proliferation depends on many factors like Ca-P phase, crystallinity and therewith related degradation behaviour of the coating [45-48]. We previously reported a decrease in DNA amounts in hMSCs on electrospun fibres coated with a Ca-P layer similar to the one used in the present study as compared to the uncoated fibres [43], which is in accordance to the results obtained here with hybrid 3DF+ESP scaffolds. Different apatite structures [49] seeded with MC3T3-E1 cells showed lower cell number compared to tissue culture plastic after different time points (4 and 14 days) and Anselme and co-workers [45] showed that proliferation of human bone derived cells on plasma sprayed hydroxyapatite (HA) coatings was only possible after prolonged soaking of the coated scaffolds in culture medium. In contrast, PLLA films coated with apatite or collagen/apatite blend showed a significantly higher proliferation of Saos-2 cells compared to bare PLLA films [50]. It is therefore difficult to draw general conclusions on the effect of Ca-P on proliferation of MSCs. In the present study, however, the effect of $\mathrm{Ca}-\mathrm{P}$ coating on cell number was only visible for hybrid scaffolds, and not for $3 \mathrm{DF}$ ones, which indeed suggest that the "clogging" effect caused by physical presence of the Ca-P layer may be of bigger importance that the chemical effect of presence of $\mathrm{Ca}-\mathrm{P}$ or release of calcium and phosphate ions.

While in vitro studies on combination of ESP and 3D RP scaffolds have been performed [19-20,44], they have mainly assessed cell proliferation, morphology and biochemical expression of typical markers like ALP and GAG on cell lines or animal derived cells. In order to assess applicability of these technologies in tissue repair and regeneration, experiments with a cell source from humans is of importance prior to 
in vivo testing. Therefore, we seeded our scaffolds with hMSCs and analysed the gene expression of various osteogenic markers at two different time points - day 7 and day 21 .

The applied Ca-P coating contains a mixture of OCP and CA, biologically relevant phases of $\mathrm{Ca}-\mathrm{P}$. The bioactivity of $\mathrm{Ca}-\mathrm{P}$ coatings in a bony environment that is believed to originate in degradation of $\mathrm{Ca}-\mathrm{P}$ is the main reasons for their use in orthopaedic and maxillo-facial implants. This degradation leads to an increase in local ion concentration in the vicinity of the implant, resulting in subsequent precipitation of a bone like carbonated apatite on the substrate [51]. Previous studies performed on similar coatings have shown the formation of a carbonated apatitic phase two weeks after an OCP coated Ti plate was placed in alpha-MEM [51] suggesting that the degradation process starts earlier. In the current experimental set up, the released calcium and /or phosphate ions plausibly affected differentiation of hMSCs. Tada and co-workers observed increased BMP-2 expression [52] in dental pulp cells due to elevated levels of calcium, which is in accordance with our results using hMSCs. Another study [53] showed that at calcium concentrations greater than $6 \mathrm{mM}$, MC3T3E1 osteoblasts showed enhanced mineralisation and expression of angiopoietin 1(Ang -1) - that promotes the structural integrity of blood vessels and variation in expression of angiopoietin-2 (Ang -2), a naturally occurring antagonist for promoting blood vessel growth. Besides angiogenic activity, Ang -1 is also involved in osteogenesis and over-expression of Ang-1 led to enhanced ALP activity, OC production and mineralisation.[54] Calcium concentration could play a role in osteogenic differentiation and reproducing hematopoetic stem cell niche or bone marrow by controlling the expression of angiopoietin related genes. Recent results from our group also showed a threefold increase in BMP-2 levels in hMSCs after $6 \mathrm{hrs}$ of culture with $7.8 \mathrm{mM}$ calcium.[55] Besides BMP-2, the gene the expression of which was consistently upregulated in coated scaffolds was OP. The extremely high levels of expression $(\sim 40$ and 70 fold) are comparable to earlier studies performed on ceramics [56] where OP expression showed a 200,000 fold increase in tricalcium phosphate ceramics compared to cultures on tissue culture plastic. Beck et al. [57] showed that phosphate is a specific signal for inducing OP expression and further elucidated possible signalling pathways for the regulation of OP [58]. Other osteogenic markers like cbfa1, a tran- 
scription factor linked to osteoblast proliferation and differentiation and a master switch in the osteogenic differentiation of mesenchymal stromal cells [59] was also upregulated on day 7 in coated scaffolds. Arafat et al. [32] also observed the same trend in cbfal expression in porcine MSCs on rapid prototyped PCL-TCP scaffolds coated with carbonated HA on days 17 and 24.

It is interesting to note that most of the observed upregulation of genes due to scaffold modifications (predominantly presence of Ca-P) occurred in basic medium as opposed to the mineralisation medium. While this facet needs further investigation, it suggests that standard culturing protocols for $2 \mathrm{D}$ cell cultures may not yield the same results when other cues like Ca-P coatings are incorporated into scaffolds.

\section{CONCLUSIONS}

$\mathrm{T}$ he combination of 3DF and ESP technologies led to the fabrication of scaffolds that could provide mechanical stability and contain a random electrospun mesh mimicking the ECM. Further functionalisation of these scaffolds with a Ca-P coating using a biomimetic process led to a hybrid scaffold containing physical and chemical cues for osteogenic differentiation. The presence of the electrospun mesh did not significantly increase the cell numbers of cultured of hMSCs as expected. While no positive effect of ESP mesh was observed on gene expression of osteogenic markers tested in uncoated scaffolds, the presence of $\mathrm{CaP}$ coating resulted in significantly higher expression of some osteogenic markers, particularly in basic cell culture medium. Our results show that, by combining scaffolding technologies and biomaterials, biological performance of bone tissue engineering scaffolds can be positively altered to lead to a desired outcome.

\section{ACKNOWLEDGEMENTS}

The authors would like to thank Ms. Celia Cruz for technical assistance. 


\section{REFERENCES}

1. Hutmacher DW, Schantz T, Zein I, Ng KW, Teoh SH, Tan KC. Mechanical properties and cell cultural response of polycaprolactone scaffolds designed and fabricated via fused deposition modeling. J Biomed Mater Res 2001;55(2):203-216.

2. Williams JM, Adewunmi A, Schek RM, Flanagan CL, Krebsbach $\mathrm{PH}$, Feinberg SE, et al. Bone tissue engineering using polycaprolactone scaffolds fabricated via selective laser sintering. Biomaterials 2005;26(23):4817-4827.

3. Melchels FP, Feijen J, Grijpma DW. A poly(D,L-lactide) resin for the preparation of tissue engineering scaffolds by stereolithography. Biomaterials 2009;30(23-24):3801-3809.

4. Lopez-Heredia MA, Sohier J, Gaillard C, Quillard S, Dorget M, Layrolle P. Rapid prototyped porous titanium coated with calcium phosphate as a scaffold for bone tissue engineering. Biomaterials 2008;29(17):2608-2615.

5. Sherwood JK, Riley SL, Palazzolo R, Brown SC, Monkhouse DC, Coates M, et al. A three-dimensional osteochondral composite scaffold for articular cartilage repair. Biomaterials 2002;23(24):47394751 .

6. Moroni L, de Wijn JR, van Blitterswijk CA. Three-dimensional fiber-deposited PEOT/PBT copolymer scaffolds for tissue engineering: Influence of porosity, molecular network mesh size, and swelling in aqueous media on dynamic mechanical properties. Journal of Biomedical Materials Research Part A 2005;75A(4):957-965.

7. Woodfield TB, Van Blitterswijk CA, De Wijn J, Sims TJ, Hollander AP, Riesle J. Polymer scaffolds fabricated with pore-size gradients as a model for studying the zonal organization within tissueengineered cartilage constructs. Tissue Eng 2005;11(9-10):1297-1311.

8. Moroni L, Curti M, Welti M, Korom S, Weder W, De Wijn JR, et al. Anatomical 3D fiber-deposited scaffolds for tissue engineering: Designing a neotrachea. Tissue Engineering 2007;13(10):2483-2493.

9. Dalton PD, Grafahrend D, Klinkhammer K, Klee D, Moller M. Electrospinning of polymer melts: Phenomenological observations. 
Polymer 2007;48(23):6823-6833.

10. Doshi J, Reneker DH. Electrospinning Process and Applications of Electrospun Fibers. Journal of Electrostatics 1995;35(2-3):151-160.

11. Li CM, Vepari C, Jin HJ, Kim HJ, Kaplan DL. Electrospun silk-BMP-2 scaffolds for bone tissue engineering. Biomaterials 2006;27(16):3115-3124.

12. Neal RA, McClugage SG, Link MC, Sefcik LS, Ogle RC, Botchwey EA. Laminin Nanofiber Meshes That Mimic Morphological Properties and Bioactivity of Basement Membranes. Tissue Engineering Part C-Methods 2009;15(1):11-21.

13. Ranganath $\mathrm{SH}$, Wang $\mathrm{CH}$. Biodegradable microfiber implants delivering paclitaxel for post-surgical chemotherapy against malignant glioma. Biomaterials 2008;29(20):2996-3003.

14. Yang F, Murugan R, Wang S, Ramakrishna S. Electrospinning of nano/micro scale poly(L-lactic acid) aligned fibers and their potential in neural tissue engineering. Biomaterials 2005;26(15):2603-2610.

15. Casper CL, Stephens JS, Tassi NG, Chase DB, Rabolt JF. Controlling surface morphology of electrospun polystyrene fibers: Effect of humidity and molecular weight in the electrospinning process. Macromolecules 2004;37(2):573-578.

16. De Vrieze S, Van Camp T, Nelvig A, Hagstrom B, Westbroek P, De Clerck K. The effect of temperature and humidity on electrospinning. Journal of Materials Science 2009;44(5):1357-1362.

17. Deitzel JM, Kleinmeyer J, Harris D, Tan NCB. The effect of processing variables on the morphology of electrospun nanofibers and textiles. Polymer 2001;42(1):261-272.

18. Moroni L, Licht R, de Boer J, de Wijn JR, van Blitterswijk CA. Fiber diameter and texture of electrospun PEOT/PBT scaffolds influence human mesenchymal stem cell proliferation and morphology, and the release of incorporated compounds. Biomaterials 2006;27(28):49114922.

19. Martins A, Chung S, Pedro AJ, Sousa RA, Marques AP, Reis $\mathrm{RL}$, et al. Hierarchical starch-based fibrous scaffold for bone tissue engineering applications. J Tissue Eng Regen Med 2009;3(1):37-42. 
20. Moroni L, Schotel R, Hamann D, de Wijn JR, van Blitterswijk CA. 3D fiber-deposited electrospun integrated scaffolds enhance cartilage tissue formation. Advanced Functional Materials 2008;18(1):5360 .

21. He DY, Sun XF, Zhao LD. Hydroxylapatite coatings by microplasma spraying. Journal of Inorganic Materials 2007;22(4):754-758.

22. Havelin LI, Engesaeter LB, Espehaug B, Furnes O, Lie SA, Vollset SE. The Norwegian Arthroplasty Register: 11 years and 73,000 arthroplasties. Acta Orthop Scand 2000;71(4):337-353.

23. Leeuwenburgh S, Layrolle P, Barrere F, de Bruijn J, Schoonman $\mathrm{J}$, van Blitterswijk CA, et al. Osteoclastic resorption of biomimetic calcium phosphate coatings in vitro. J Biomed Mater Res 2001;56(2):208215.

24. Brown WE. Octacalcium Phosphate and Hydroxyapatite. Nature 1962;196(4859):1048-\&.

25. Rey C. Calcium phosphate biomaterials and bone mineral. Differences in composition, structures and properties. Biomaterials 1990;11:13-15.

26. Oliveira AL, Mano JF, Reis RL. Nature-inspired calcium phosphate coatings: present status and novel advances in the science of mimicry. Curr Opin Solid St M 2003;7(4-5):309-318.

27. Liu YL, Hunziker EB, Layrolle P, De Bruijn JD, De Groot K. Bone morphogenetic protein 2 incorporated into biomimetic coatings retains its biological activity. Tissue Engineering 2004;10(1-2):101108.

28. Liu YL, Layrolle P, van Blitterswijk C, de Groot K. Incorporation of proteins into biomimetic hydroxyapatite coatings. Key Eng Mat 2000;192-1:71-74.

29. Kokubo T, Ito S, Huang ZT, Hayashi T, Sakka S, Kitsugi T, et al. $\mathrm{Ca}, \mathrm{P}-$ rich layer formed on high-strength bioactive glass-ceramic A-W. J Biomed Mater Res 1990;24(3):331-343.

30. Barrere F, van Blitterswijk CA, de Groot K, Layrolle P. Influence of ionic strength and carbonate on the Ca-P coating formation from SBFx5 solution. Biomaterials 2002;23(9):1921-1930. 
31. Oliveira AL, Costa SA, Sousa RA, Reis RL. Nucleation and growth of biomimetic apatite layers on 3D plotted biodegradable polymeric scaffolds: effect of static and dynamic coating conditions. Acta Biomater 2009;5(5):1626-1638.

32. Arafat MT, Lam CX, Ekaputra AK, Wong SY, Li X, Gibson I. Biomimetic composite coating on rapid prototyped scaffolds for bone tissue engineering. Acta Biomater 2010.

33. Du C, Meijer GJ, van de Valk C, Haan RE, Bezemer JM, Hesseling $\mathrm{SC}$, et al. Bone growth in biomimetic apatite coated porous Polyactive((R)) 1000PEGT70PBT30 implants. Biomaterials 2002;23(23):4649-4656.

34. Woodfield TBF, Malda J, de Wijn J, Peters F, Riesle J, van Blitterswijk CA. Design of porous scaffolds for cartilage tissue engineering using a three-dimensional fiber-deposition technique. Biomaterials 2004;25(18):4149-4161.

35. Moroni L, Hamann D, Paoluzzi L, Pieper J, de Wijn JR, van Blitterswijk CA. Regenerating articular tissue by converging technologies. PLoS One 2008;3(8):e3032.

36. Moroni L, de Wijn JR, van Blitterswijk CA. 3D fiber-deposited scaffolds for tissue engineering: influence of pores geometry and architecture on dynamic mechanical properties. Biomaterials 2006;27(7):974-985.

37. Both SK, Van der Muijsenberg AJC, Van Blitterswijk CA, De Boer J, De Bruijn JD. A rapid and efficient method for expansion of human mesenchymal stem cells. Tissue Engineering 2007;13(1):3-9.

38. Du C, Klasens P, Haan RE, Bezemer J, Cui FZ, de Groot K, et al. Biomimetic calcium phosphate coatings on Polyactive 1000/70/30. J Biomed Mater Res 2002;59(3):535-546.

39. Moroni L, Poort G, Van Keulen F, de Wijn JR, van Blitterswijk CA. Dynamic mechanical properties of 3D fiber-deposited PEOT/PBT scaffolds: An experimental and numerical analysis. J Biomed Mater Res A 2006(78):605-614.

40. Nandakumar A, Yang L, Habibovic P, van Blitterswijk C. Calcium Phosphate Coated Electrospun Fiber Matrices as Scaffolds for Bone Tissue Engineering. Langmuir 2009. 
41. Brown WE, Eidelman N, Tomazic B. Octacalcium phosphate as a precursor in biomineral formation. Adv Dent Res 1987;1(2):306-313.

42. Weiner S. Transient precursor strategy in mineral formation of bone. Bone 2006;39(3):431-433.

43. Nandakumar A, Yang L, Habibovic P, van Blitterswijk C. Calcium phosphate coated electrospun fiber matrices as scaffolds for bone tissue engineering. Langmuir 2010;26(10):7380-7387.

44. Kim G, Son J, Park S, Kim W. Hybrid Process for Fabricating 3D Hierarchical Scaffolds Combining Rapid Prototyping and Electrospinning. Macromol Rapid Comm 2008;29(19):1577-1581.

45. Anselme K, Sharrock P, Hardouin P, Dard M. In vitro growth of human adult bone-derived cells on hydroxyapatite plasma-sprayed coatings. J Biomed Mater Res 1997;34(2):247-259.

46. Arinzeh TL, Tran T, McAlary J, Daculsi G. A comparative study of biphasic calcium phosphate ceramics for human mesenchymal stemcell-induced bone formation. Biomaterials 2005;26(17):3631-3638.

47. Knabe C, Berger G, Gildenhaar R, Meyer J, Howlett CR, Markovic $B$, et al. Effect of rapidly resorbable calcium phosphates and a calcium phosphate bone cement on the expression of bone-related genes and proteins in vitro. J Biomed Mater Res A 2004;69(1):145154.

48. Midy V, Dard M, Hollande E. Evaluation of the effect of three calcium phosphate powders on osteoblast cells. J Mater Sci Mater Med 2001;12(3):259-265.

49. Chou YF, Huang W, Dunn JC, Miller TA, Wu BM. The effect of biomimetic apatite structure on osteoblast viability, proliferation, and gene expression. Biomaterials 2005;26(3):285-295.

50. Mak AFT, Chen Y, Wang M, Li JS, Wong MS. In vitro behavior of osteoblast-like cells on PLLA films with a biomimetic apatite or apatite/collagen composite coating. Journal of Materials ScienceMaterials in Medicine 2008;19(6):2261-2268.

51. Barrere F, van der Valk CM, Dalmeijer RA, van Blitterswijk $\mathrm{CA}$, de Groot K, Layrolle P. In vitro and in vivo degradation of biomimetic octacalcium phosphate and carbonate apatite coatings on tita- 
nium implants. J Biomed Mater Res A 2003;64(2):378-387.

52. Tada H, Nemoto E, Kanaya S, Hamaji N, Sato H, Shimauchi H. Elevated extracellular calcium increases expression of bone morphogenetic protein-2 gene via a calcium channel and ERK pathway in human dental pulp cells. Biochem Biophys Res Commun 2010;394(4):10931097.

53. Nakamura S, Matsumoto T, Sasaki J, Egusa H, Lee KY, Nakano $\mathrm{T}$, et al. Effect of calcium ion concentrations on osteogenic differentiation and hematopoietic stem cell niche-related protein expression in osteoblasts. Tissue Eng Part A 2010;16(8):2467-2473.

54. Jeong BC, Kim HJ, Bae IH, Lee KN, Lee KY, Oh WM, et al. COMP-Ang1, a chimeric form of Angiopoietin 1, enhances BMP2-induced osteoblast differentiation and bone formation. Bone 2010;46(2):479-486.

55. Barradas AM, Fernandes HA, Groen N, Chai YC, Schrooten J, van de Peppel J, et al. A calcium-induced signaling cascade leading to osteogenic differentiation of human bone marrow-derived mesenchymal stromal cells. Biomaterials 2012;33(11):3205-3215.

56. Yuan H, Fernandes H, Habibovic P, de Boer J, Barradas AM, de Ruiter A, et al. Osteoinductive ceramics as a synthetic alternative to autologous bone grafting. Proc Natl Acad Sci U S A 2010;107(31):1361413619.

57. Beck GR, Zerler B, Moran E. Phosphate is a specific signal for induction of osteopontin gene expression. P Natl Acad Sci USA 2000;97(15):8352-8357.

58. Beck GR, Knecht N. Osteopontin regulation by inorganic phosphate is ERK1/2-, protein kinase C-, and proteasome-dependent. Journal of Biological Chemistry 2003;278(43):41921-41929.

59. Stein GS, Lian JB, van Wijnen AJ, Stein JL, Montecino M, Javed A, et al. Runx 2 control of organization, assembly and activity of the regulatory machinery for skeletal gene expression. Oncogene 2004;23(24):4315-4329. 


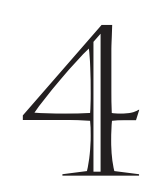

\section{Fabrication of bioactive composite scaffolds by electrospinning for bone regeneration}

Anandkumar Nandakumar, Hugo Fernandes, Jan de Boer,

Lorenzo Moroni, Pamela Habibovic, Clemens van Blitterswijk

Department of Tissue Regeneration, MIRA Institute for Biomedical Technology and Technical Medicine, University of Twente, Enschede, The Netherlands

Chance favours the prepared mind.

- Louis Pasteur 


\section{ABSTRACT}

Electrospun scaffolds are widely used for various biomedical applications. In this study, we prepared electrospun bioactive composite scaffolds combining hydroxyapatite, collagen and a synthetic polymer - PolyActive ${ }^{\mathrm{TM}}$ - to mimic naturally occurring extracellular matrix for in situ bone regeneration. Human mesenchymal stromal cells adhered and proliferated on these scaffolds. Cells on all scaffold types showed an increased metabolic activity with time. On day 4, the metabolic activity of cells cultured on PA-HA-Col in HFIP was significantly higher than that of cells grown on PA-Col samples. Furthermore, on day 6, cells on PA-HA-Col in HFIP showed significantly higher metabolic activity than those on PA and PA-Col scaffolds. Quantitative PCR analysis for a panel of osteogenic genes showed statistically significant differences between scaffolds. Cells cultured on PA-HA scaffolds had a significantly higher Osteonectin and Runx2 expression compared to those on PA-HA-Col scaffolds. Cells on PA-HA-Col in HFIP scaffolds had significantly higher expression of Alkaline Phosphatase and Collagen 1. The Bone Morphogenetic Protein-2 and S100A4 expression of PA-Col and PA-HA-Col constructs was significantly lower than the basal level expression of cells on $P A$ scaffolds. Although not statistically significant in all cases, cells cultured on PA-HA-Col in HFIP and PA-HA scaffolds had the highest expression for most of the genes analysed. The results of the study demonstrate that bioactive composite scaffolds prepared by electrospinning could find potential use in bone regeneration applications. 


\section{INTRODUCTION}

R egeneration of tissues in situ by providing the right cues to cells using Runctionalised instructive scaffolds is an attractive option for advanced therapies. In recent years, there has been a shift from engineering tissues in vitro to the regeneration of tissues in vivo. Biomimetic approaches are very appealing alternatives to mimic the native instructive potential of extracellular matrix (ECM) [1]. A relatively simple, yet flexible and powerful technique to create fibrillar matrices with ECM-like characteristics is electrospinning [2-3]. This technology involves the application of a high voltage to a polymer solution or melt leading to the formation of fibres in the nanometre to micrometre range [4-5]. By changing the flow rate, electric potential, type of solvents used, collecting distance, and ambient conditions such as humidity and temperature, scaffolds with variable porous network and physicochemical properties can be obtained [6-9]. This flexibility has led electrospun matrices to be widely used as scaffolds and delivery vehicles for drugs, proteins and growth factors [2, 10-12].

Bone is a major connective tissue mainly composed of collagen as organic matrix and hydroxyapatite (HA) as the mineral component. Combining collagen and HA is therefore a logical step towards creating scaffolds for bone regeneration. Few studies demonstrated the combination of collagen and HA in an electrospun architecture [13-14]. Thomas et al. [14] showed an increase in the Young's modulus and hardness with increasing nano-HA content from $0 \%$ to $20 \mathrm{wt} .-\%$ and Song et al. [13] demonstrated that electrospinning could not be maintained above this weight percentage due to ineffective distribution of HA by the collagen leading to precipitation of clusters of HA. Although an increased ALP expression was observed in MC3T3- E1 osteoblastic cell line when these two components were combined, the mechanical properties of such composites can be vastly improved either by cross-linking collagen or by combining them with an additional, synthetic polymer [13-14]. Researchers have combined commercially available polymers like Poly $\varepsilon$ - caprolactone (PCL), Poly -L-lactide (PLLA) and Poly[(D,L-lactide)-co-glycolide] (PLGA) with either HA or a combination of HA and collagen and have found that mechanical properties and cell behaviour can be tailored depending on the type of scaffolds used [15-17]. An alternative strategy to create composite electrospun fibres for bone tissue engineering is to use simulated body fluids to premineralise scaffolds [18-19]. This process leads to the deposition of crystals of calcium phosphate on the surface of the fibres. PolyActive ${ }^{\mathrm{TM}}$ (PA) is a Poly 
(ethylene oxide terephthalate) - poly (butylene terephthalate) (PEOT/PBT) block copolymer whose properties can be adjusted for various applications by changing the molecular weight and ratio of PEOT and PBT. This class of polymers has been used for bone [20] and cartilage tissue engineering [21], among other applications [22-24]. These polymers have also been electrospun $[9,19]$ and combined with $3 \mathrm{D}$ scaffolds for enhanced cartilage formation [25] or biomimetically coated [19] to enhance in vivo bone formation.

In this study, we aimed at creating an ECM like structure for bone regeneration in situ by electrospinning PA doped with collagen, hydroxyapatite or both components. We also compared the effect of agglomerated collagen to well dispersed collagen by changing the solvent mixture used for dissolving the blends. As suggested by Both et al. [26], human mesenchymal stromal cells (hMSCs) were cultured for seven days on these biomimetic fibrous networks to evaluate cell-material interactions and assess the influence of collagen and hydroxyapatite on osteogenic differentiation of hMSCs.

\section{MATERIALS AND METHODS}

DolyActive ${ }^{\mathrm{TM}}$ (PA) was provided by PolyVation BV, The Nether1 lands. Following an aPEOTbPBTc nomenclature, the composition used in this study was 300PEOT55PBT45 where, (a) is the molecular weight in $\mathrm{g} / \mathrm{mol}$ of the starting poly(ethylene glycol) (PEG) blocks used in the copolymerisation, while (b) and (c) are the weight ratios of the PEOT and PBT blocks, respectively. Acid soluble collagen type I powder of bovine origin was a generous gift from Kensey Nash Corporation (USA, Catalogue number 20003-04). Hydroxyapatite (HA) was provided by Progentix BV, The Netherlands.

\section{PREPARATION OF SOLUTIONS FOR ELECTROSPINNING}

All solutions were prepared and stirred overnight at room temperature before use. A $21 \mathrm{wt} .-\%$ solution of PA was prepared in a mixture of chloroform $\left(\mathrm{CHCl}_{3}\right)$-1, 1, 1, 3, 3, 3- hexafluoro-2-propanol (HFIP) (78/22 vol.-\%). A PA-HA solution of the same concentration in $\mathrm{CHCl}_{3} /$ HFIP was prepared by substituting $10 \mathrm{wt} .-\%$ of PA with HA particles. A 17.3 wt.-\% PA-collagen solution (PA: Col 90:10) was prepared in $\mathrm{CHCl}_{3} / \mathrm{HFIP}$ solution (64/36 vol.-\%). The amount of HFIP in the solvent had to be increased to facilitate the dissolution of collagen. 
Finally, PA-HA-collagen (80:10:10 by weight) blend was prepared using two different methods. In the first method, $17.3 \mathrm{wt} .-\%$ of PA-HA$\mathrm{Col}$ was prepared in $\mathrm{CHCl}_{3} / \mathrm{HFIP}$ solution (64/36 vol.-\%) while a well dispersed blend (PA-HA-Col in HFIP) was prepared by dissolving the same amount of material in $100 \%$ HFIP which is widely used as a solvent for collagen.

\section{ELECTROSPINNING}

The desired solution was loaded into a syringe and the flow rate was controlled using a syringe pump (KDS 100, KD Scientific). The other end of the syringe was connected to a needle, on which a positive high voltage was applied using a high voltage generator (Gamma High Voltage Research Inc., USA). A metallic sheet of stainless steel was the collector (ground). An electrostatic field was formed between the needle and the collector when the generator was turned on. The polymer solution was pushed through the syringe to the tip of the needle. When the electrostatic field strength overcame the surface tension of the liquid drop at the tip of the needle, the drop was stretched into fibres and deposited onto the collector. A parametric study on the variation of fibre diameter with flow rate was performed by maintaining a constant voltage $(12 \mathrm{kV})$ and distance $(15 \mathrm{~cm})$ for all the solutions while varying the flow rate $(1,5,10$ and $15 \mathrm{~mL} / \mathrm{hr})$. Temperature and humidity were monitored during the process and ranged between $19.6-20.4{ }^{\circ} \mathrm{C}$ and $33-42 \%$ respectively.

\section{CHARACTERISATION OF SCAFFOLDS}

The morphology of electrospun fibres resulting from various conditions was observed using Scanning Electron Microscopy (SEM) in secondary electron mode coupled to Energy Dispersive X-Ray (EDX) analyser (XL 30 ESEM-FEG, Philips). Fibre diameters were calculated from SEM micrographs by measuring 45 fibres per condition using Image J (National Institutes of Health, Bethesda, MD, USA). EDX was used to confirm the presence of HA in the concerned samples by detecting the calcium peak in the spectra. 


\section{PICOSIRIUS RED STAINING TO VISUALISE COLLAGEN}

Picosirius red (Polysciences, Inc.) staining was used to visualise and confirm collagen incorporation into the scaffolds. The staining was done with a slight modification to the manufacturer's protocol. Briefly, the scaffolds were placed in solution A for 2 minutes, washed in distilled water and placed in solution $B$ for 110 minutes. The scaffolds were then placed in solution $\mathrm{C}$ for 2 minutes, followed by $45 \mathrm{sec}$ ond incubation in $70 \%$ ethanol. The scaffolds were then dehydrated, mounted on a glass slide and visualised under polarised light.

\section{HUMAN MESENCHYMAL STROMAL CELL(HMSC) ISOLATION}

Bone marrow aspirates were obtained after written informed consent, and hMSCs were isolated and proliferated as described previously [26]. Briefly, aspirates were re-suspended by using 20 -gauge needles, plated at a density of $5 \times 10^{5} \mathrm{cell} / \mathrm{s} / \mathrm{cm}^{2}$ and cultured in hMSC proliferation medium containing $\alpha$-minimal essential medium (Life Technologies), $10 \%$ fetal bovine serum (Cambrex), $0.2 \mathrm{mM}$ ascorbic acid (Asap; Life Technologies), 2 mM L-glutamine (Life Technologies), 100 units $/ \mathrm{ml}$ penicillin (Life Technologies), $10 \mu \mathrm{g} / \mathrm{ml}$ streptomycin (Life Technologies), and $1 \mathrm{ng} / \mathrm{ml}$ basic fibroblast growth factor (FGF) (Instruchemie). Cells were grown at $37^{\circ} \mathrm{C}$ in a humid atmosphere with $5 \% \mathrm{CO}_{2}$. Medium was refreshed twice a week, and cells were used for further sub-culturing or cryopreservation. The hMSC basic medium was composed of hMSC proliferation medium without basic FGF. Cells were trypsinised prior to seeding on scaffolds.

\section{IN VITRO EXPERIMENTS}

The in vitro experiments were performed with cells from one donor at passage 2. Electrospun discs with a diameter of $15 \mathrm{~mm}$ and thickness of about $50 \mu \mathrm{m}$ were soaked in $100 \%$ ethanol for 30 minutes and dried in a laminar flow cabinet. The scaffolds were washed twice with sterile PBS, transferred to a 24 well non-treated plate (NUNC) and incubated at $37^{\circ} \mathrm{C}$ in a humid atmosphere with $5 \% \mathrm{CO}_{2}$ for four hours in basic cell culture medium. Rubber O-rings (from Eriks BV, The Netherlands) were used to secure the discs in place and to prevent them from 
floating. After removing the medium, each scaffold was seeded with 50,000 cells in $50 \mu \mathrm{l}$ basic medium. The cell-scaffold constructs were incubated for three hours to allow cell attachment and topped up to 1 $\mathrm{ml}$ with basic medium. Seven discs from each group were seeded with cells and one scaffold was used as a blank for Alamar Blue measurements. Medium was refreshed after each Alamar Blue measurement.

\section{ALAMAR BLUE ASSAY FOR CELL METABOLISM}

Cell metabolism was assessed using Alamar blue assay according to the manufacturer's protocol. Briefly, culture medium was replaced with medium containing 10\% (v/v) Alamar blue solution (Biosource, Camarillo, CA, USA) and the cells were incubated at $37^{\circ} \mathrm{C}$ for 4 hours. Fluorescence was measured at $590 \mathrm{~nm}$ on a Perkin Elmer Victor ${ }^{3} 1420$ Multilabel plate reader. Cell metabolism was analysed on day 1, 4 and 6 and the readout from the scaffolds $(n=7)$ was corrected with the blank from each group.

\section{RNA ISOLATION AND GENE EXPRESSION ANALYSIS USING QUANTITATIVE PCR}

To analyse the expression of osteogenic markers by hMSCs, total RNA was isolated using the TRIzol ${ }^{\circledR}$ method according to the manufacturer's protocol. Briefly, samples were lysed directly from scaffolds by adding $200 \mu 1$ of TRIzol reagent (Invitrogen). After chloroform addition and phase separation by centrifugation, the aqueous phase containing the RNA was collected and precipitated using isopropylalcohol. The RNA was washed with $75 \%$ ethanol and re-suspended in RNAse-free water. Two samples from each scaffold type were combined to ensure sufficient quantity of RNA ( $\mathrm{n}=3$ for analysis). The quality and quantity of RNA was analysed by gel electrophoresis and spectrophotometry. One microgram of RNA was used for first strand cDNA synthesis using iScript (Bio-Rad) according to the manufacturer's protocol. One microlitre of undiluted cDNA was used for subsequent analysis. PCR was performed on a Light Cycler real time PCR machine (Roche) using SYBR green I master mix (Invitrogen). Data was analysed using Light Cycler software version 3.5.3, using the fit point method by setting the noise band to the exponential phase of the reaction to exclude background 
fluorescence. Expression of osteogenic marker genes was normalised to $18 \mathrm{~S}$ (5'-CGGCTACCACATCCAAGGAA-3' and 5'-GCTGGAATTACCGCGGCT-3') levels and fold inductions were calculated using the comparative $\Delta \mathrm{CT}$ method.[27] The following primer sequences were used for the osteogenic marker genes: OC (5'-GGCAGCGAGGTAGTGAAGAG-3' and 5'-GATGTGGTCAGCCAACTCGT-3'), BSP (5'-TGCCTTGAGCCTGCTTCC-3' and 5'-CAAAATTAAAGCAGTCTTCATTTTG-3'), RunX2 (5'-GGAGTGGACGAGGCAAGAGTTT-3' and 5'-AGCTTCTGTCTGTGCCTTCTGG- 3'), Collagen type 1 (5'-AGGGCCAAGACGAAGACATC-3' and 5'AGATCACGTCATCGCACAACA-3'), OP (5'-CCAAGTAAGTCCAACGAAAG-3 and 5'-GGTGATGTCCTCGTCTGTA-3'), ON (5'-ACTGGCTCAAGAACGTCCTG-3' and 5'-GAGAGAATCCGGTACTGTGG-3'), S100A4 (5'-AGCTTCTTGGGGAAAAGGAC-3' and 5'-CCCCAACCACATCAAGAGG-3') and ALP (5'-GACCCTTGACCCCCACAAT-3' and 5'-GCTCGTACTGCATGTCCCCT-3'). For amplification of BMP-2, a gene-specific primer mix was used (SA Biosciences), according to the manufacturer's protocol.

\section{Cell MORPhOlOGY USing SEM}

On day 7, one sample from each group was used for SEM analysis. The media was removed and the scaffolds were washed twice with PBS and fixed in $0.14 \mathrm{M}$ cacodylate/1.5\% glutaraldehyde buffer for 30 minutes. After rinsing with PBS, the scaffolds were dehydrated in a series of increasing ethanol concentrations $(70 \%, 80 \%, 90 \%, 96 \%, 100 \% \times 2)$, 15 minutes in each concentration, before being dried in a critical point dryer (Balzers CPD-030). The samples were then sputter coated with gold (Cressington) for observation on the SEM.

\section{STATISTICAL ANALYSIS}

One way ANOVA with Tukey's multiple comparison test was performed. The level of significance was set at 0.05. All data presented are expressed as mean $+/$ - standard deviation. 


\section{RESULTS}

PARAMETRIC STUDY ON ELECTROSPINNING AND CHARACTERISATION OF SCAFFOLDS

A 11 five solutions (PA, PA-HA, PA-Col, PA-HA-Col and PA-HAA Col in HFIP) were electrospun at $1,5,10$ and $15 \mathrm{~mL} / \mathrm{hr}$ while maintaining a voltage at $12 \mathrm{kV}$ and a collecting distance of $15 \mathrm{~cm}$. The variation of fibre diameter with flow rate for the different groups is shown in figure 1. For a fixed voltage and distance, an increase in flow rate is expected to increase the fibre diameter as more material flows through the nozzle for the same time. This trend was generally observed in all groups except PA-HA-Col where no obvious change in fibre diameter with flow rate occurred.

Another consequence of increasing the flow rate is the tendency to form beads as more material needs to be dried before reaching the collector. Bead formation was indeed observed to be more pronounced at

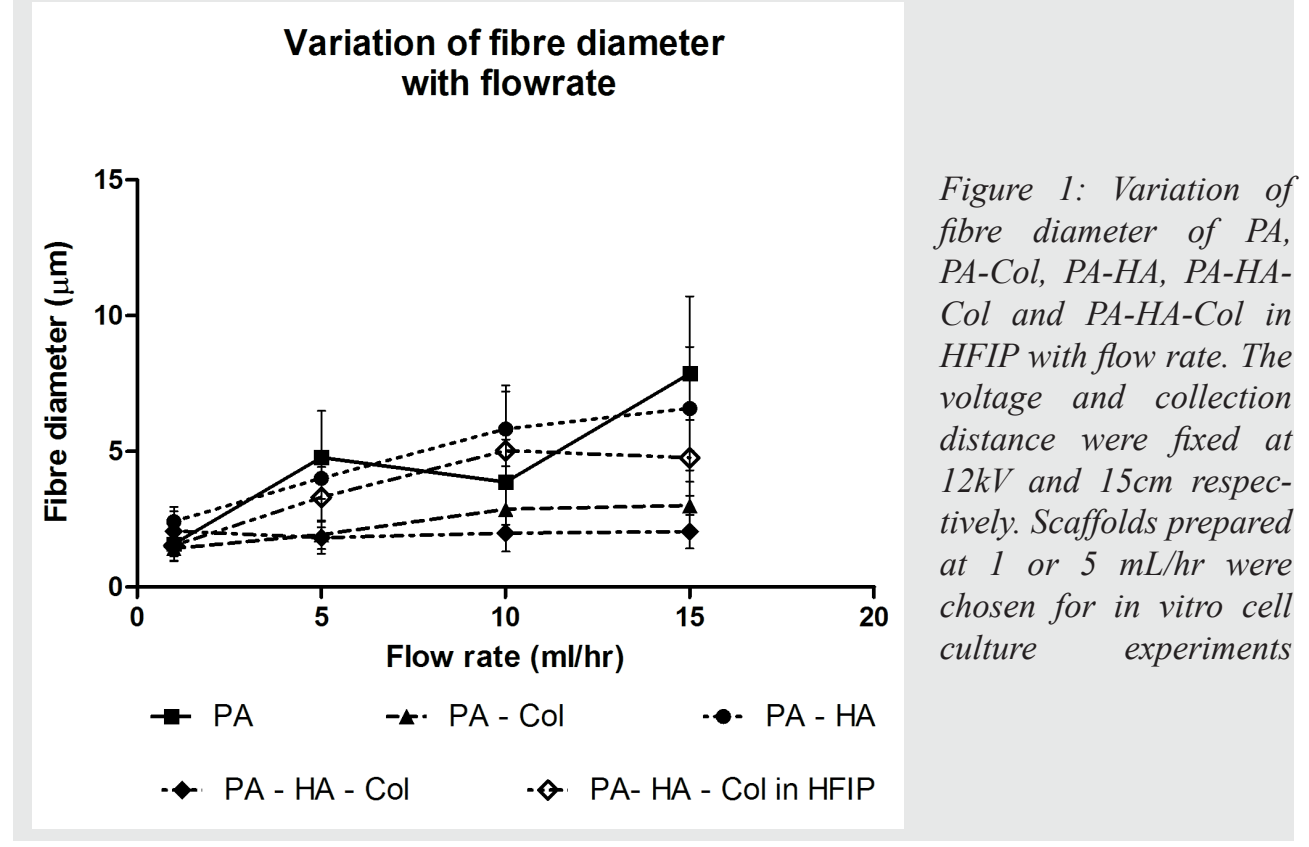

10 and $15 \mathrm{~mL} / \mathrm{hr}$, with PA-HA-Col and PA-Col having the most beads among all solutions. Collagen is insoluble in $\mathrm{CHCl}_{3}$ and the addition 


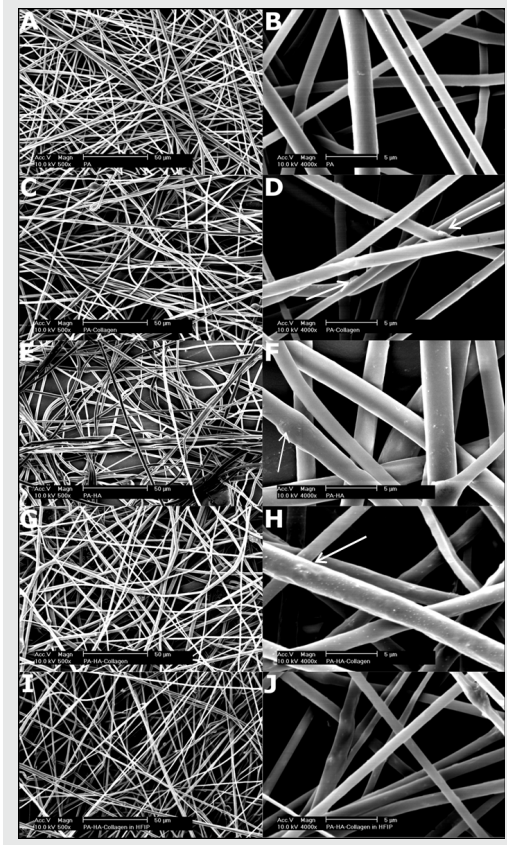

Figure 2: SEM micrographs of $P A$ ( $A$ and B), PA-Col (C and D), PA-HA (E and F), PA-HA-Col ( $G$ and $H$ ) and PA-HA-Col in HFIP (I and J) at different magnifications. Scale bar: $A, C, E, G, I: 50 \mu m$ and $B, D, F$, $H, J: 5 \mu \mathrm{m}$. Arrows indicate inclusions arising from partially dissolved collagen

of HFIP increases the solubility. However, collagen is not completely soluble in this solvent mixture and this leads to the formation of ag-

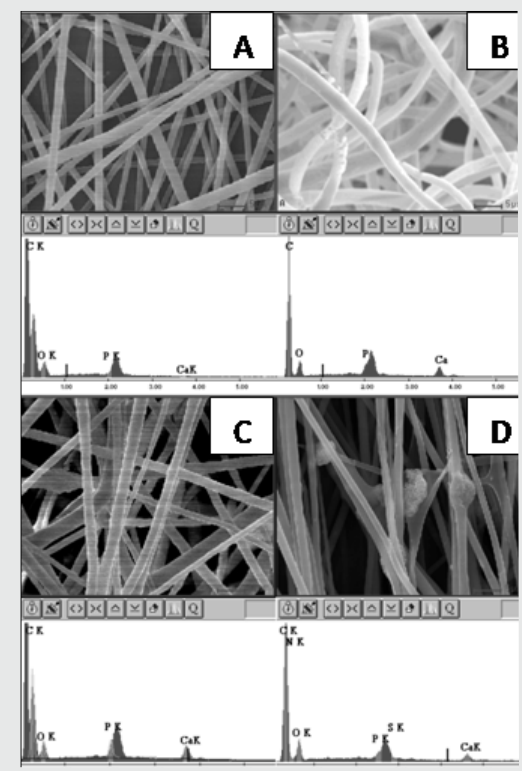

Figure 3: EDX spectra of different scaffolds used PA, PA-HA, PA-HA-Col and PA-HA-Col in HFIP (A$D)$. Calcium and Phosphorus peaks are visible in all the scaffolds doped with HA while they are absent in the polymer alone (PA) scaffold 
glomerates. From the above study, one sample from each of the conditions was chosen for in vitro experiments - PA (1 mL/hr), PA-Col (5 $\mathrm{mL} / \mathrm{hr})$, PA-HA $(1 \mathrm{~mL} / \mathrm{hr})$, PA-HA-Col $(5 \mathrm{~mL} / \mathrm{hr})$ and PA-HA-Col in HFIP $(1 \mathrm{~mL} / \mathrm{hr})$. The samples were chosen such that there was minimum variation in the fibre diameters among groups as fibre diameters

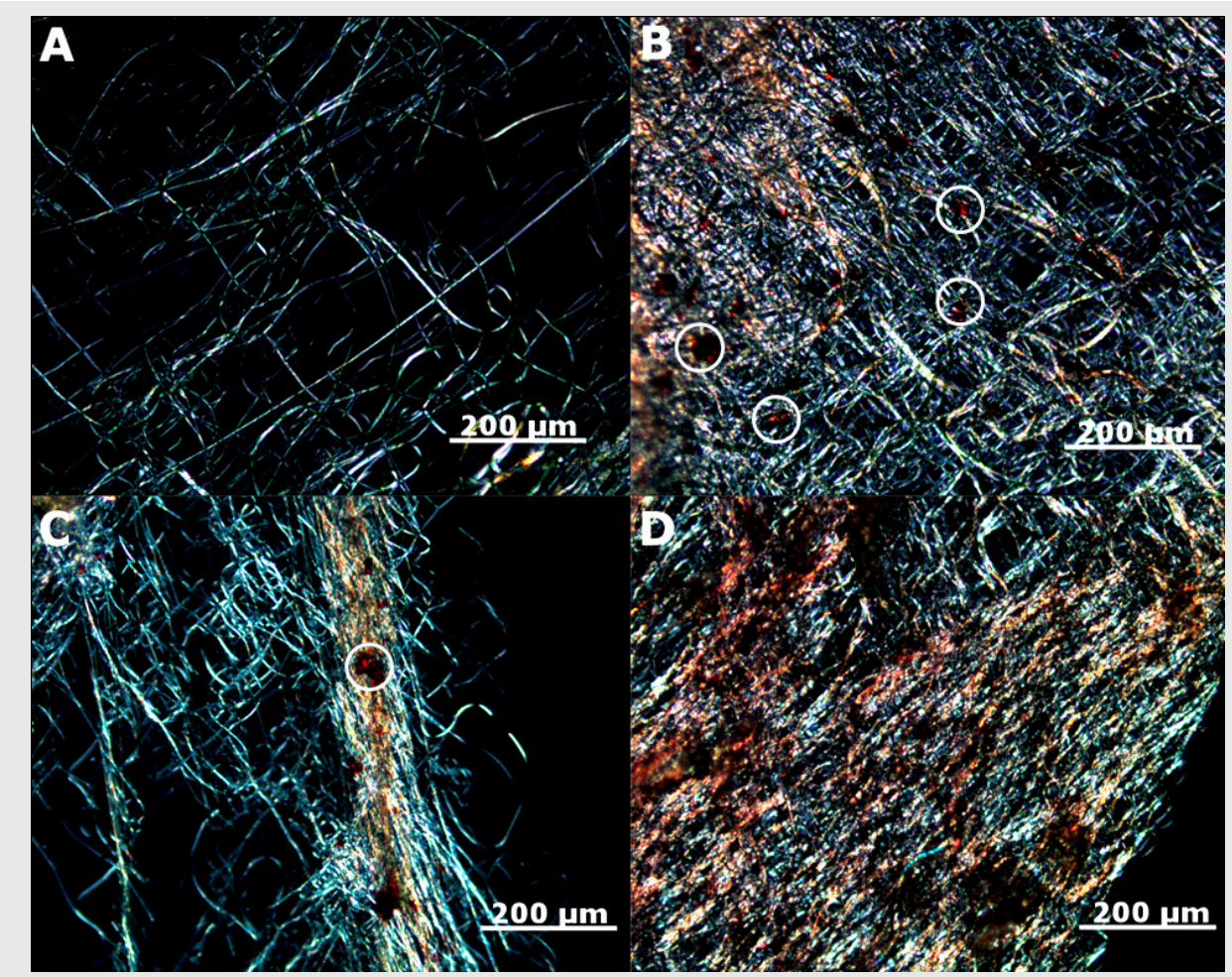

Figure 4: Picosirius red staining to visualise collagen in scaffolds under polarised light. PA, PA-Col, PA-HA-Col and PA-HA-Col in HFIP (A-D). PA scaffolds do not stain for collagen while other scaffolds doped with collagen stain positively. The appearance of red agglomerates in $B$ and $C$ (denoted by white circles) is to be noted. These are agglomerates of collagen which are partially dissolved due to the type of solvent system used leading to a localisation of collagen. PA-HA-Col in HFIP (D) gives a very uniform distribution of collagen in the scaffold

have been shown to influence proliferation of hMSCs. [9] It is plausible that the groups containing collagen in $\mathrm{CHCl}_{3} / \mathrm{HFIP}$ solvent mixture require a higher flow rate to produce homogeneous fibres, an aspect that requires further investigation. 
The SEM micrographs of these samples at different magnifications $(500 x, 4000 x)$ are shown in figure 2 . It can be observed that the addition of components like collagen and HA leads to the formation of beads and agglomerates on the fibres. The PA-HA-Col blend prepared in $100 \%$ HFIP was well dispersed compared to the blend prepared in $\mathrm{CHCl}_{3} / \mathrm{HFIP}$ mixture (Figure 2J and $2 \mathrm{H}$ ), where agglomerates were observed.

The presence of HA in the scaffolds was confirmed using EDX and is shown in figure 3 . The PA scaffold without HA was used as a control (3A) and no peaks of calcium were visible. In PA-HA, PA-HA-Col and PA-HA-Col in HFIP (3B-D) EDX patterns, calcium and phosphorus peaks were present which confirms that HA has been incorporated in the scaffolds.

Picosirius red staining was performed to confirm the presence of collagen in the concerned scaffolds using PA scaffold as a control (4A). Figure 4 shows the picosirius staining on the different collagen containing scaffolds. In PA-Col and PA-HA-Col, it can be clearly seen that collagen is present as red lumps and orange fibres confirming that the use of $\mathrm{CHCl}_{3} / \mathrm{HFIP}$ system leads to incomplete dissolution of the collagen powder. In contrast, the staining of PA -HA-Col in HFIP (4D) shows a more uniform dispersion (orange fibres) without clumps.

\section{METABOLIC ACTIVITY OF HMSCS ON SCAFFOLDS}

Alamar blue assay was performed on days 1,4 and 6 on all scaffolds and the results are presented in figure 5. The metabolic activity of cells in all scaffolds increased with time. On day 4, cells grown on PA-HA$\mathrm{Col}$ in HFIP scaffolds had significantly higher metabolic activity than those cultured on PA-Col scaffolds. On day 6, cells of PA-HA-Col in HFIP had the highest metabolic activity, being significantly higher than the metabolic activity of cells cultured on PA and PA-Col scaffolds.

\section{CELL SPREADING AND MORPHOLOGY USING SEM}

SEM micrographs of hMSCs on various scaffolds on day 7 are shown in figure 6. Low magnification images (A-E, $100 \mathrm{x}$ ) show the presence of a cell sheet on all the scaffolds. This suggests that cells attached and 
proliferated on all scaffold formulations used. Higher magnification

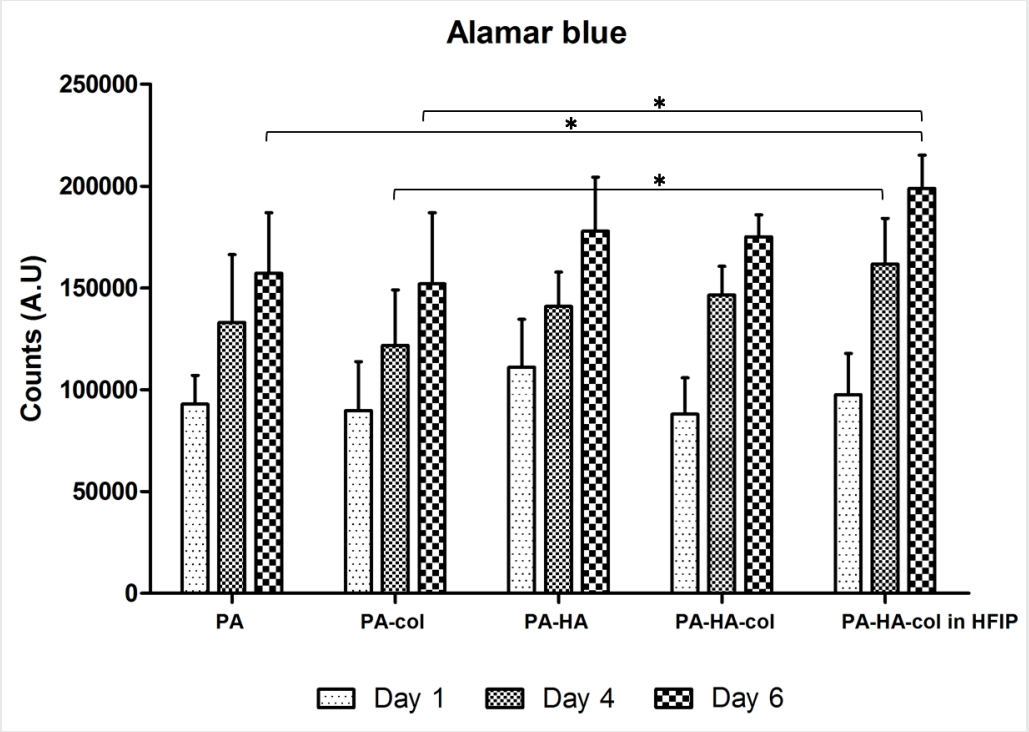

Figure 5: Metabolic activity of cells on days 1, 4 and 6 assessed by Alamar blue measurements. * represents significant differences $(p<0.05)$. Data shown for $n=7$ samples and expressed as mean \pm standard deviation

images (F-J, $1000 \mathrm{x})$ show cells interacting with the electrospun fibres. Interaction of single cells with the fibres along with secreted ECM was observed at very high magnification (K-O, $4000 \mathrm{x})$. The cells have spindle shape, fibroblast like morphology, and have produced their own ECM.

\section{GENE EXPRESSION ANALYSIS USING QUANTITATIVE PCR}

The effect of the scaffolds on the osteogenic potential of hMSCs was analysed using quantitative PCR on a panel of genes indicative for osteogenic differentiation (Figure 7). The fold induction was calculated relative to the expression of genes on the PA scaffold. No statistically significant differences were observed on hMSCs cultured on various scaffolds for Osteopontin (OP) and Osteocalcin (OC). The presence of HA and well dispersed collagen in the scaffolds tended to upregulate 
Bone Sialoprotein (BSP) expression.

PA-HA-Col scaffolds showed a statistically significant downregulation of Osteonectin (ON) and RunX2 compared to PA-HA scaffolds. Furthermore, scaffolds with collagen agglomerates (PA-Col and PAHA-Col) tended to show a downregulation of RunX2, but the downregulation was not statistically significant. The S100A4 expression of

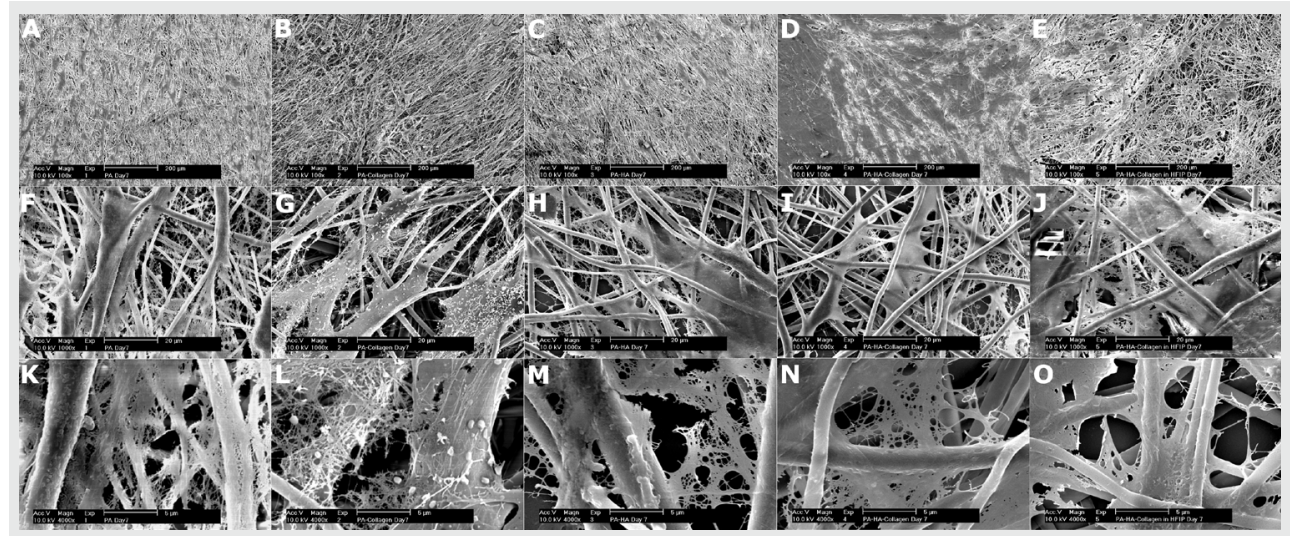

Figure 6: Cell morphology on various electrospun scaffolds on day 7 using SEM. PA (A, F and K), PA-Col (B, G and L), PA-HA(C, H and M), PA-HA-Col (D, I and N) and PA-HA-Col in HFIP (E, $J$ and $O)$ in different magnifications. Scale bar: A-E: $200 \mu \mathrm{m}, F-J: 20 \mu \mathrm{m}$ and $K-O: 5 \mu m$

cells cultured on PA-HA-Col scaffolds was significantly lower than that of cells on PA scaffolds. The addition of HA or collagen tended to downregulate S100A4 gene expression and this was more pronounced when collagen agglomerates were present.

HMSCs cultured on PA-HA-Col in HFIP scaffolds had a significantly higher expression of collagen ( $\mathrm{Col})$ compared to those cultured on PA-Col scaffolds. It was observed that the gene expression decreased when collagen was incorporated in a mixture of $\mathrm{CHCl}_{3}$ and $\mathrm{HFIP}$ and the expression tended to increase in the presence of HA. The highest expression of Col was observed in the combination of HA and collagen dissolved in 100\% HFIP. Cells on PA-Col scaffolds showed a significantly lower BMP2 expression compared to basal level expression on PA scaffolds. The trend observed was that presence of collagen ag- 
glomerates downregulated BMP2 expression whereas the presence of HA tended to restore expression to the same level as observed on PA scaffolds.

Cells cultured on PA-HA-Col in HFIP scaffolds showed a highly significant upregulation $(\mathrm{p}<0.01)$ in ALP expression compared to those

\section{Gene expression of osteogenic markers after 7 days of in vitro culture}
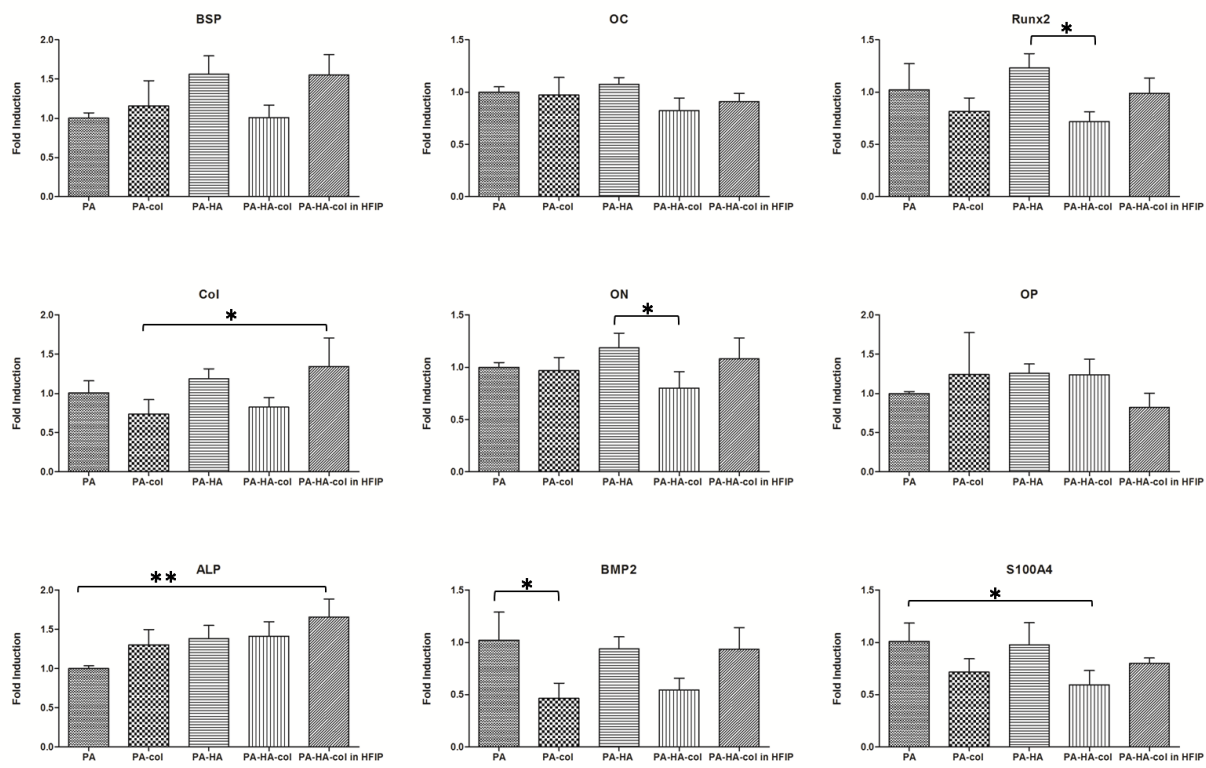

Figure 7: qPCR analysis for genes encoding osteogenic markers after 7 days of culture. * represents significant differences $(p<0.05)$ and $* *$ represents highly significant differences $(p<0.01)$. Data shown for $n=3$ samples and expressed as mean \pm standard deviation

on PA scaffolds. In general, the addition of HA or collagen tended to upregulate ALP expression. When the effect of different solvents was compared, i.e., a mixture of $\mathrm{CHCl}_{3}$ / $\mathrm{HFIP}$ vs. $100 \% \mathrm{HFIP}$, it was observed that the expression of all genes except OP was higher in the case of the well dispersed (100\% HFIP) blend. This may indicate that a more uniform dispersion in the solution increases the expression of osteogenic markers when compared to a non dispersed solution and that collagen distribution within the doped fibre network may influence stem cell differentiation. 


\section{DISCUSSION}

Z lectrospinning is a facile technique and has become an established

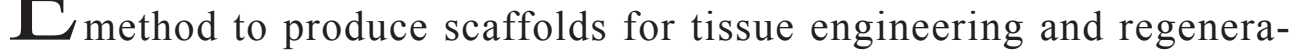
tive medicine. The possibility of altering fibre dimensions from few hundred nanometres to few tens of microns, surface morphology from smooth to rough and alignments (random, uni- and bi-axial) by changing processing parameters and solvent systems makes it an attractive scaffold fabrication technology [28-29]. In this study, various composite fibre meshes were spun at different flow rates to assess fibre formation and morphology and to obtain suitable meshes for in vitro assessment of their potential in influencing mesenchymal stem cell osteogenic differentiation. The fibre diameter is expected to increase with increasing flow rate as more material passes through the nozzle and a higher volume is spun. All groups generally displayed this trend except PA-HA-Col. Since collagen does not dissolve in chloroform, partially dissolved collagen particles formed aggregates (as confirmed by picosirius red staining) during electrospinning. This could be associated with the presence of beads as analysed by SEM. When solvent was changed to $100 \%$ HFIP, a well dispersed blend was obtained resulting in fibres with fewer beads. In general, the addition of components to the polymer solution increases the formation of aggregates. When EDX mapping was performed on scaffolds doped with HA, bright spots indicating calcium and phosphorous were present (data not shown). Jose et al. [15] combined PLGA with collagen and nanoHA (spheres of $100-150 \mathrm{~nm}$ diameter) to create aligned electrospun fibre meshes for bone tissue engineering. A more uniform dispersion of nano-HA in the solution was achieved by room temperature sonication, although at 5 wt.-\% of nano-HA agglomerates were observed. They also observed that addition of nano-HA at low amounts acted as mechanical reinforcement for the scaffold while higher amounts of doping had a negative effect on the mechanical properties. This was also observed in the study by Yang et al. [17] where a drop in modulus occurred when the amount of nano-HA $(60 \mathrm{~nm}$ in length and $20 \mathrm{~nm}$ in width) was increased above $25 \%$. Hence, there exists a fine balance in adding HA to increase bioactivity while ensuring that mechanical properties are not compromised. Kim et al. [30] showed that a surfactant could be used to achieve a homogeneous dispersion of HA in 
a polymer system. Prabhakaran et al. [16] showed a decrease in tensile strength of composite PLLA/HA and PLLA/HA/Col scaffolds over pure PLLA scaffolds. This could be attributed to the increased amounts of doping which might have increased the brittleness of the scaffold.

HMSCs were cultured for 7 days and their metabolic activity on various scaffolds was assessed at three time points. All scaffolds promoted cell attachment and by day 7 , most parts of the scaffolds were covered with a cell sheet. On day 4, cells cultured on the well dispersed blend of PA-HA-Col in HFIP showed significantly higher metabolic activity compared to the cells grown on PA-Col scaffolds. The cells on these scaffolds also had significantly higher metabolic activity compared to those cultured on PA and PA-Col scaffolds on day 6. Since collagen dissolves better in pure HFIP, it might have been distributed more uniformly throughout the scaffold leading to a more favourable environment for cell growth. Yang et al. [17] showed an increased ALP activity of rat bone marrow cells in nano-HA/PCL composites in comparison to non-doped PCL scaffolds. Ekaputra et al. [31] prepared composite meshes of PCL and collagen and showed that osteogenic differentiation markers like collagen I, osteopontin and osteocalcin were more pronounced in the composite meshes compared to plain PCL scaffolds when porcine MSCs were cultured in osteogenic mineralisation medium.

In this study, electrospun meshes mimicking the main organic and inorganic components of bone were evaluated as potential inductive scaffolds for tissue regeneration. Fibrous networks doped with collagen agglomerates (PA-HA-Col in $\mathrm{CHCl}_{3} / \mathrm{HFIP}$ ) led to a downregulation of early (RunX2) and late (ON, Collagen, and BMP2) osteogenic markers. However, a more uniformly dispersed blend (PA-HA-Col in pure HFIP) tended to show higher induction of all genes except OP compared to the non dispersed formulation. This may suggest that a more uniform collagen distribution instead of agglomerates is preferable for a favourable cellular response. Lee et al. [32] cultured hMSCs on PLGA scaffolds doped with different amounts of nano-HA and reported significantly enhanced expression of osteogenic markers like ALP, BSP and OC in scaffolds with HA compared to plain polymer samples, the trend that was also observed in our study. However, in the study by Lee et al., RunX2 and Col expression levels were similar for 
cells cultured on different fibre compositions, whereas in the present study a higher expression of those two genes in the PA-HA scaffold was observed. Earlier studies have shown that incorporation of HA along with BMP-2 on electrospun silk fibroin scaffolds [12] resulted in the highest amount of calcium deposition and upregulation of BMP-2 transcript levels in hMSCs compared to other scaffold types.

The positive effect observed upon incorporation of both HA and collagen appeared to be dependent on the distribution of collagen in the fibres. In the presence of collagen agglomerates, the beneficial effect of HA was absent. When a more uniform distribution of collagen was obtained using 100\% HFIP, the combination of HA and collagen resulted in enhanced expression of osteogenic markers. In a recent study by Patlolla and co-workers [33], a composite scaffold consisting of $20 \% \mathrm{HA} / 80 \% \mathrm{~b}-\mathrm{TCP}$ and PCL was prepared in two different solvent systems and this had an effect on cell growth kinetics. The effect of using different solvents was also noticeable in our study when the agglomerates and well dispersed blends of PA-HA-Col were compared.

Li et al. [34] showed that hMSCs cultured on PCL scaffolds could only be induced to differentiate into adipogenic, osteogenic or chondrogenic lineages by the addition of certain biological compounds. In our study, the addition of HA and collagen resulted in an upregulation of osteogenic genes even in the absence of differentiation cues in the medium. Our results demonstrate the potential advantages of using bioactive scaffolds mimicking the ECM physical and chemical cues for regeneration of bone tissue. These bioactive scaffolds could be used alone in non-loading bearing applications or can be coupled with load bearing scaffolds, such as those fabricated by $3-\mathrm{D}$ fibre deposition [35].

\section{CONCLUSIONS}

$\mathrm{V}$ arious types of composite bioactive scaffolds were electrospun using PolyActive ${ }^{\mathrm{TM}}$ as a carrier polymer of HA and collagen inclusions and the effect of flow rate on fibre diameter was studied. HMSCs cultured on these scaffolds adhered well and proliferated after 7 days of culture. Gene expression analysis suggested that the presence of HA combined with a homogeneous collagen dispersion increased the expression of osteogenic markers and may find applications for bone regeneration in situ. 


\section{ACKNOWLEDGEMENTS}

The authors thank Ms. Celia Cruz for technical assistance, and Mr.

1 Jeroen Leijten and Ms. Joyce Doorn for their valuable input.

\section{REFERENCES}

1. Chung EH, Gilbert M, Virdi AS, Sena K, Sumner DR, Healy KE. Biomimetic artificial ECMs stimulate bone regeneration. J Biomed Mater Res A 2006;79(4):815-826.

2. Neal RA, McClugage SG, Link MC, Sefcik LS, Ogle RC, Botchwey EA. Laminin Nanofiber Meshes That Mimic Morphological Properties and Bioactivity of Basement Membranes. Tissue Engineering Part C-Methods 2009;15(1):11-21.

3. Liao S, Murugan R, Chan CK, Ramakrishna S. Processing nanoengineered scaffolds through electrospinning and mineralization suitable for biomimetic bone tissue engineering. J Mech Behav Biomed Mater 2008;1(3):252-260.

4. Dalton PD, Grafahrend D, Klinkhammer K, Klee D, Moller M. Electrospinning of polymer melts: Phenomenological observations. Polymer 2007;48(23):6823-6833.

5. Doshi J, Reneker DH. Electrospinning Process and Applications of Electrospun Fibers. Journal of Electrostatics 1995;35(2-3):151-160.

6. Deitzel JM, Kleinmeyer J, Harris D, Tan NCB. The effect of processing variables on the morphology of electrospun nanofibers and textiles. Polymer 2001;42(1):261-272.

7. Casper CL, Stephens JS, Tassi NG, Chase DB, Rabolt JF. Controlling surface morphology of electrospun polystyrene fibers: Effect of humidity and molecular weight in the electrospinning process. Macromolecules 2004;37(2):573-578.

8. De Vrieze S, Van Camp T, Nelvig A, Hagstrom B, Westbroek P

De Clerck K. The effect of temperature and humidity on electrospinning. J Mater Sci 2009;44(5):1357-1362.

9. Moroni L, Licht R, de Boer J, de Wijn JR, van Blitterswijk CA. Fi- 
ber diameter and texture of electrospun PEOT/PBT scaffolds influence human mesenchymal stem cell proliferation and morphology, and the release of incorporated compounds. Biomaterials 2006;27(28):49114922.

10. Ranganath $\mathrm{SH}$, Wang $\mathrm{CH}$. Biodegradable microfiber implants delivering paclitaxel for post-surgical chemotherapy against malignant glioma. Biomaterials 2008;29(20):2996-3003.

11. Yang F, Murugan R, Wang S, Ramakrishna S. Electrospinning of nano/micro scale poly(L-lactic acid) aligned fibers and their potential in neural tissue engineering. Biomaterials 2005;26(15):2603-2610.

12. Li CM, Vepari C, Jin HJ, Kim HJ, Kaplan DL. Electrospun silk-BMP-2 scaffolds for bone tissue engineering. Biomaterials 2006;27(16):3115-3124.

13. Song JH, Kim HE, Kim HW. Electrospun fibrous web of collagen-apatite precipitated nanocomposite for bone regeneration. J Mater Sci Mater Med 2008;19(8):2925-2932.

14. Thomas V, Dean DR, Jose MV, Mathew B, Chowdhury S, Vohra YK. Nanostructured biocomposite scaffolds based on collagen coelectrospun with nanohydroxyapatite. Biomacromolecules 2007;8(2):631637.

15. Jose MV, Thomas V, Xu Y, Bellis S, Nyairo E, Dean D. Aligned bioactive multi-component nanofibrous nanocomposite scaffolds for bone tissue engineering. Macromol Biosci 2010;10(4):433-444.

16. Prabhakaran MP, Venugopal J, Ramakrishna S. Electrospun nanostructured scaffolds for bone tissue engineering. Acta Biomater 2009;5(8):2884-2893.

17. Yang F, Both SK, Yang X, Walboomers XF, Jansen JA. Development of an electrospun nano-apatite/PCL composite membrane for GTR/GBR application. Acta Biomater 2009;5(9):3295-3304.

18. Li X, Xie J, Yuan X, Xia Y. Coating electrospun poly(epsiloncaprolactone) fibers with gelatin and calcium phosphate and their use as biomimetic scaffolds for bone tissue engineering. Langmuir 2008;24(24):14145-14150.

19. Nandakumar A, Yang L, Habibovic P, van Blitterswijk C. Cal- 
cium Phosphate Coated Electrospun Fiber Matrices as Scaffolds for Bone Tissue Engineering. Langmuir 2009.

20. Du C, Meijer GJ, van de Valk C, Haan RE, Bezemer JM, Hesseling $\mathrm{SC}$, et al. Bone growth in biomimetic apatite coated po rous Polyactive $((\mathrm{R}))$ 1000PEGT70PBT30 implants. Biomaterials 2002;23(23):4649-4656.

21. Woodfield TBF, Malda J, de Wijn J, Peters F, Riesle J, van Blitterswijk CA. Design of porous scaffolds for cartilage tissue engineering using a three-dimensional fiber-deposition technique. Biomaterials 2004;25(18):4149-4161.

22. Bulstra SK, Geesink RG, Bakker D, Bulstra TH, Bouwmeester SJ, van der Linden AJ. Femoral canal occlusion in total hip replacement using a resorbable and flexible cement restrictor. J Bone Joint Surg Br 1996;78(6):892-898.

23. Wang H, Pieper J, Peters F, van Blitterswijk CA, Lamme EN. Synthetic scaffold morphology controls human dermal connective tissue formation. J Biomed Mater Res A 2005;74(4):523-532.

24. van Dijkhuizen-Radersma R, Metairie S, Roosma JR, de Groot K, Bezemer JM. Controlled release of proteins from degradable poly(ether-ester) multiblock copolymers. J Control Release 2005;101(1-3):175-186.

25. Moroni L, Schotel R, Hamann D, de Wijn JR, van Blitterswijk CA. 3D fiber-deposited electrospun integrated scaffolds enhance cartilage tissue formation. Advanced Functional Materials 2008;18(1):5360 .

26. Both SK, Van der Muijsenberg AJC, Van Blitterswijk CA, De Boer J, De Bruijn JD. A rapid and efficient method for expansion of human mesenchymal stem cells. Tissue Engineering 2007;13(1):3-9.

27. Livak KJ, Schmittgen TD. Analysis of relative gene expression data using real-time quantitative PCR and the 2(-Delta Delta C(T)) Method. Methods 2001;25(4):402-408.

28. Kwon IK, Kidoaki S, Matsuda T. Electrospun nano- to microfiber fabrics made of biodegradable copolyesters: structural characteristics, mechanical properties and cell adhesion potential. Biomaterials 2005;26(18):3929-3939. 
29. Li D, Xia YN. Electrospinning of nanofibers: Reinventing the wheel? Advanced Materials 2004;16(14):1151-1170.

30. Kim HW, Lee HH, Knowles JC. Electrospinning biomedical nanocomposite fibers of hydroxyapaite/poly(lactic acid) for bone regeneration. Journal of Biomedical Materials Research Part A 2006;79A(3):643-649.

31. Ekaputra AK, Zhou Y, Cool SM, Hutmacher DW. Composite electrospun scaffolds for engineering tubular bone grafts. Tissue Eng Part A 2009;15(12):3779-3788.

32. Lee JH, Rim NG, Jung HS, Shin H. Control of Osteogenic Differentiation and Mineralization of Human Mesenchymal Stem Cells on Composite Nanofibers Containing Poly [lactic-co-(glycolic acid)] and Hydroxyapatite. Macromolecular Bioscience 2010;10(2):173-182.

33. Patlolla A, Collins G, Arinzeh TL. Solvent-dependent properties of electrospun fibrous composites for bone tissue regeneration. Acta Biomaterialia 2010;6(1):90-101.

34. Li WJ, Tuli R, Huang XX, Laquerriere P, Tuan RS. Multilineage differentiation of human mesenchymal stem cells in a three-dimensional nanofibrous scaffold. Biomaterials 2005;26(25):5158-5166.

35. Moroni L, Poort G, Van Keulen F, de Wijn JR, van Blitterswijk CA. Dynamic mechanical properties of 3D fiber-deposited PEOT/PBT scaffolds: An experimental and numerical analysis. J Biomed Mater Res A 2006(78):605-614. 


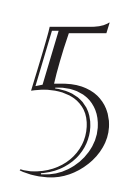

\section{Monolithic and assembled polymer-hydroxyapatite composites for bone tissue engineering}

\footnotetext{
Anandkumar Nandakumar ${ }^{\mathrm{a}}, \mathrm{Cé}$ lia $\mathrm{Cruz}^{\mathrm{a}, \mathrm{b}}$, Anouk Mentink ${ }^{\mathrm{a}}$, Lorenzo Moroni ${ }^{\mathrm{a}}$, Clemens van Blitterswijk ${ }^{\mathrm{a}}$, Pamela Habibovic ${ }^{\mathrm{a}}$

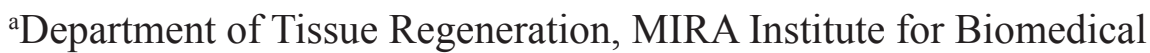
Technology and Technical Medicine, University of Twente, The Netherlands ${ }^{b}$ Faculty of Engineering of the University of Porto, Rua Dr. Roberto Frias, Porto, Portugal
} 


\section{ABSTRACT}

The rationale for the use of polymer - ceramic composites for bone tissue engineering stems from the natural composition of bone, with collagen type I and biological apatite as main organic and inorganic constituents, respectively. In the present study, composite materials of poly (ethylene oxide terephthalate)/poly (butylene terephtalate) - (PEOT/PBT) copolymer and hydroxyapatite (HA) at a weight ratio of 85:15 were prepared by rapid prototyping $(R P)$ using two routes. In the first approach, pre-extruded composite filaments of PA-HA were processed using three dimensional fibre deposition ( $3 D F)$ (conventional composite scaffolds). In the second approach, $P A$ scaffolds were fabricated using $3 D F$ and combined with HA pillars that were produced inside stereolithographic moulds and that fitted inside the pores of the PA $3 D$ structure (assembled composite scaffolds) The scaffolds were characterised using scanning electron microscopy (SEM), energy dispersive $x$-ray analysis (EDX) and the $H A$ properties were analysed using X-ray diffraction (XRD). Analysis of calcium and phosphate release in a simulated physiological solution revealed significantly higher values for HA pillars compared to other scaffolds. Human mesenchymal stromal cells (hMSCs) were cultured on polymer (3DF), conventional composite (3DF-HA) and assembled composite (HA assembled in $3 D F$ ) scaffolds and assessed for morphology, metabolic activity, DNA amount and gene expression of osteogenic markers using real-time quantitative PCR. SEM images showed that cells attached on and infiltrated all the scaffolds. Assembled composites had a higher metabolic activity compared to 3DF-HA scaffolds while no significant differences were observed in DNA amounts. Gene expression of osteopontin $(O P)$ in the assembled composite was significantly higher compared to the conventional composites. Based on these results, the strategy of composite fabrication by assembly appears to be a promising alternative to the conventional composite fabrication route for bone tissue engineering applications. 


\section{INTRODUCTION}

one is a naturally occurring biocomposite composed of organic 3 and inorganic components. The organic part of the bone is mainly composed of collagen type I among other proteins and is responsible for the tensile strength and toughness of bone tissue while the inorganic mineral component is calcium phosphate, essentially HA, that provides stiffness and strength to bone [1-2]. While autografts are generally considered the golden standard in bone repair and regeneration, problems with donor site morbidity and availability exist [3], while allografts suffer from a risk of disease transmission [4-5]. In recent years, tissue engineering has been considered as an alternative treatment strategy for bone repair and regeneration [6]. The use of a suitable scaffold that acts as a carrier of cells and/or growth factors in a tissue engineered construct and its fabrication is highly important to obtain desirable properties like mechanical strength, porosity and interconnectivity. Preparation of polymer - ceramic composite scaffolds is one strategy that has been explored. The underlying rationale for the use of composites is to develop a scaffold with a composition similar to that of natural bone. Synthetic polymers like Poly L-lactic acid (PLLA) [7-9], Poly $\varepsilon$ - caprolactone (PCL) [10-11], Polylacticco-glycolic acid (PLGA) [7, 12-13] or naturally occurring collagen [14-15] have been combined with HA to fabricate composite scaffolds. Use of conventional fabrication methods like salt leaching - phase inversion [14], thermally induced phase separation (TIPS) [15] and other similar techniques do not offer a strict control over porosity and interconnectivity and invariably use organic solvents. Pore interconnectivity is essential for supply of nutrients and metabolites while residuals of organic solvents can be cytotoxic [16]. The need to control the architecture, porosity and mechanical properties of scaffolds led to the advent of RP technologies. Several RP techniques like selective laser sintering (SLS) [17-18], fused deposition modelling (FDM) [10] and precision extrusion deposition (PED) [19] have been used for fabricating composites by combining polymers like poly hydroxybutyrate-co-hydroxyvalerate, PLLA, PCL with different calcium phosphate phases like carbonated hydroxyapatite, HA and $\beta$-Tricalcium Phosphate. These techniques also offer the advantage of being integrated to imaging modalities (e.g. MRI, CT) in order to fabricate specific scaf- 
folds and implants customised for patients.

3D fibre deposition (3DF) is an extrusion based RP technique where a polymer is melted and extruded through a nozzle and the material deposition is controlled by a robotic arm. Scaffolds with variable porosities and different orientations between successive layers can be fabricated. 3DF has been used for fabricating polymeric scaffolds for tissue engineering of cartilage [20] and osteochondral [21] defects. While $3 \mathrm{DF}$ is a very versatile technique for fabricating polymeric scaffolds, processing of composites is more difficult owing to the high viscosity of the polymer-ceramic melt and the clogging of the nozzles. In addition to affecting fabrication and processability, these phenomena also limit the amount of ceramic that can be incorporated into the scaffold. Hence, we studied two different routes to create composite scaffolds using RP. Polyactive ${ }^{\mathrm{TM}}$ (PA), a poly (ethylene oxide terephthalate)/poly (butylene terephtalate) - (PEOT/PBT) copolymer with tunable physicochemical properties that has been widely used in different forms for tissue engineering applications [20, 22-23] was the polymer of choice. HA was chosen as the ceramic phase of the composite.

In the first, conventional approach, filaments of polymer ceramic composite at desired weight ratios were extruded and used as starting material for preparing the scaffolds using 3DF. In the other approach, previously developed in our group [21], polymer scaffolds were fabricated using $3 \mathrm{DF}$ and ceramic particles were fabricated in the form of pillars by sintering the ceramic slurry poured into negative moulds prepared by stereolithography. The two components were then assembled together to create a composite scaffold. The latter approach overcomes the problems associated with conventional fabrication and offers the advantage of incorporating higher amounts of HA into the scaffold. Human mesenchymal stromal cells (hMSCs) were seeded on these scaffolds and cell proliferation and osteogenic differentiation were studied. 3DF scaffolds fabricated from polymer alone were used as a control.

\section{MATERIALS AND METHODS}

Dolyactive ${ }^{\mathrm{TM}}$ was provided by PolyVation BV, The Netherlands. Following an aPEOTbPBTc nomenclature, the composition used in 
this study was 300PEOT55PBT45 where, (a) is the molecular weight in $\mathrm{g} / \mathrm{mol}$ of the starting poly(ethylene glycol) (PEG) blocks used in the copolymerisation, while (b) and (c) are the weight ratios of the PEOT and PBT blocks, respectively. HA powder for the ceramic preparation was provided by Progentix BV, The Netherlands. It was synthesised using wet precipitation. The powder was not sintered and was phasepure HA with a particle size below $63 \mu \mathrm{m}$.

\section{FABRICATION OF 3DF SCAFFOLDS}

\section{PRODUCTION OF COMPOSITE FILAMENTS AND FABRICATION OF 3DF SCAFFOLDS BY RAPID PROTOTYPING}

Composite filaments of PA and HA were extruded using a screw extruder (ARTECS). Briefly, a desired amount of PA pellets and HA powder were added to the extruder and mixed for 5 minutes at a temperature of $180{ }^{\circ} \mathrm{C}$. The composite filaments were then drawn out and cut into small pellets for processing by rapid prototyping. For scaffold fabrication, composite filaments with a maximum of $20 \%$ HA by weight were used.

3D scaffolds were fabricated by rapid prototyping using a Bioplotter (Envisiontec $\mathrm{GmbH}$, Germany), which is an XYZ robotic device as previously described [24]. Briefly, polymer or composite granules (PA-HA) were loaded onto a stainless steel syringe set at a temperature between $195-210{ }^{\circ} \mathrm{C}$ (higher temperatures for composites) using a thermostat controlled cartridge unit, fixed on the " $X$ "-mobile arm of the apparatus. A pressure of 5 bars (nitrogen) for composites (4 bars for polymer) was applied to the syringe through a pressurised cap once the polymer had melted. Rectangular block models were loaded on the Bioplotter CAM (PrimCAM, Switzerland) software and deposited layer by layer as the polymer was extruded through a nozzle $(0.7 \mathrm{~mm}$ OD) on a stage. The deposition speed was varied between $150-250$ $\mathrm{mm} / \mathrm{min}$ (lower speeds for composites). The spacing between fibres in the same layer was set at $0.8 \mathrm{~mm}$, the layer thickness was $0.225 \mathrm{~mm}$ and the scaffold height was set at $4 \mathrm{~mm}$. A $0-90^{\circ}$ configuration was used for scaffold architecture where fibres were deposited with $90^{\circ}$ orientation steps between successive layers. 
PREPARATION OF CERAMIC SLURRY, MOULDS AND ASSEMBLING HA INTO 3DF SCAFFOLDS

Pillars of HA were fabricated in a two step process. First, a negative mask was designed with Rhinoceros and fabricated using stereolithography (Envisiontec, Germany). The masks were then filled with an HA slurry prepared by vigorously mixing $8.2 \mathrm{~g}$ calcined HA (20 hours in an oven at $1000{ }^{\circ} \mathrm{C}$ ), $3.55 \mathrm{~g}$ of non-calcined HA, $5 \mathrm{~g}$ of demineralised water, $0.3 \mathrm{~g}$ of methylcellulose solution $(2 \% \mathrm{w} / \mathrm{v}$ methylcellulose in demineralised water), $0.55 \mathrm{~g}$ of ammonia, and $3.525 \mathrm{~g}$ of sieved paraffin particles, resulting in a $30 \%$ porosity of the HA particles. The HA pillars were obtained by sintering in a furnace (Nabertherm, Germany) at $1150{ }^{\circ} \mathrm{C}$. HA particles were sterilised by autoclaving and the pillars were press fitted into the pores of the $3 \mathrm{DF}$ scaffolds.

\section{CHARACTERISATION OF SCAFFOLDS}

The architecture and composition of the different types of scaffolds were characterised using SEM coupled to EDX analyser (XL 30 ESEM - FEG, Philips), Quanta 600F ESEM. XRD (Rigaku Miniflex) analysis was performed on the HA particles in the range $2 \Theta 2^{\circ}$ to $70^{\circ}$. The porosity of the rapid prototyped scaffolds was calculated from SEM measurements of fibre diameter, layer thickness and fibre spacing using the following formula [25]:

$$
\text { Porosity }=1-\frac{\pi}{4} \frac{1}{\frac{\text { Fibre spacing }}{\text { Fibre diameter }}} \frac{1}{\frac{\text { Layer thickness }}{\text { Fibre diameter }}}
$$

Compression tests were performed on scaffolds with a diameter of $4 \mathrm{~mm}$ and a length of $4 \mathrm{~mm}$ and using a mechanical testing apparatus (Zwick Z050, Germany) to obtain the Young's modulus during compression. A $0.5 \mathrm{kN}$ load cell was used and the samples were compressed at a rate of $1 \mathrm{~mm} / \mathrm{min}$ up to a maximum of $30 \%$ strain. The modulus was calculated from the stress strain curves as the slope of the initial linear region (strain 5-8\%) neglecting the toe region due to initial settling of the specimen. A total of four samples per scaffold group were evaluated. 
CALCIUM AND PHOSPHATE RELEASE

A simulated physiological solution (SPS) with ionic concentration of $137 \mathrm{mM} \mathrm{Na}^{+}$and $177 \mathrm{mM} \mathrm{Cl}^{-}$was used to determine the release of calcium and phosphate. Triplicates of each sample (PA, 3DF-HA and HA pillars), weighing $250 \mathrm{mg}$ each were soaked into $30 \mathrm{ml}$ of SPS at $37^{\circ}$ $\mathrm{C}$ under shaking for 3 weeks after which samples were removed and concentration of calcium and phosphate was measured using QuantiChromTM Calcium Assay Kit (DICA-500) and QuantiChromTM Phosphate Assay Kit (DIPA-500). Optical density of samples after adding reagents from the kits was read with a microplate spectrophotometer (Thermo Scientific Multiskan GO) at $612 \mathrm{~nm}$ and $620 \mathrm{~nm}$ for calcium and phosphate release respectively. HA pillars were used in the release study in order to determine the maximum amount of calcium and phosphate ions that could be released and 3DF scaffolds were considered as blank and used for correction of concentration values.

\section{HUMAN MESENCHYMAL STROMAL CELL (HMSC) ISOLATION AND CULTURE}

Bone marrow aspirates were obtained after written informed consent, and hMSCs were isolated and proliferated as described previously [26]. Briefly, aspirates were resuspended by using 20 -gauge needles, plated at a density of $5 \times 105$ cells $/ \mathrm{cm} 2$ and cultured in hMSC proliferation medium containing $\alpha$-minimal essential medium (Life Technologies), $10 \%$ foetal bovine serum (Lonza), $0.2 \mathrm{mM}$ ascorbic acid (Asap; Life Technologies), 2 mM L-glutamine (Life Technologies), 100 units/ml penicillin (Life Technologies), $10 \mu \mathrm{g} / \mathrm{ml}$ streptomycin (Life Technologies), and $1 \mathrm{ng} / \mathrm{ml}$ basic fibroblast growth factor (FGF) (Instruchemie). Cells were grown at $37^{\circ} \mathrm{C}$ in a humid atmosphere with $5 \% \mathrm{CO}_{2}$. Medium was refreshed twice a week, and cells were used for further subculturing or cryopreservation. The hMSC basic medium was composed of hMSC proliferation medium without basic FGF. Mineralisation medium was composed of hMSC basic medium supplemented with $10^{-8} \mathrm{M}$ dexamethasone (Sigma, St. Louis, MO) and 0.01M $\beta$-glycerophosphate (BGP; Sigma). Cells were trypsinised prior to seeding on scaffolds.

The in vitro experiments were performed with cells from one donor at passage 3 . Scaffolds $\left(10 \times 10 \times 4 \mathrm{~mm}^{3}\right)$ were soaked in $100 \%$ ethanol for 
30 minutes and dried overnight in a laminar flow cabinet. The scaffolds were washed twice with sterile PBS, transferred to a 25 well nontreated polystyrene plate (Greiner Bio One) and incubated at $37^{\circ} \mathrm{C}$ in a humid atmosphere with $5 \% \mathrm{CO}_{2}$ for four hours in basic cell culture medium. After removing the medium, each scaffold was seeded with 800,000 cells approximately in $105 \mu \mathrm{l}$ basic medium. The cell-scaffold constructs were incubated for three hours to allow cell attachment and topped up to $2 \mathrm{ml}$ with appropriate media. Scaffolds were cultured either in basic media or mineralisation media and medium was refreshed twice a week. As control, T25 flasks were seeded at 5000 cells $/ \mathrm{cm}^{2}$ in basic and mineralisation medium.

\section{CELl METABOLISM AND AMOUNT OF DNA}

Cell metabolism was assessed using Alamar blue assay according to the manufacturer's protocol. Briefly, culture medium was replaced with medium containing 10\% (v/v) Alamar blue solution (Biosource, Camarillo, CA, USA) and the cell-scaffold constructs $(n=3)$ were incubated at $37^{\circ} \mathrm{C}$ for 4 hours. Fluorescence was measured at $590 \mathrm{~nm}$ on a Perkin Elmer Victor3 1420 Multilabel plate reader. Cell metabolism was analysed on day 11 and 21 and the readout from the scaffolds was corrected with the blank from each group.

After 21 days, seeded scaffolds $(n=3)$ were washed with PBS and frozen at $-80^{\circ} \mathrm{C}$ overnight. The constructs were then digested at $56{ }^{\circ} \mathrm{C}$ in a Tris-EDTA buffered solution containing $1 \mathrm{mg} / \mathrm{ml}$ proteinase $\mathrm{K}, 18.5$ $\mu \mathrm{g} / \mathrm{ml}$ pepstatin A and $1 \mu \mathrm{g} / \mathrm{ml}$ iodoacetamide (Sigma-Aldrich) for 18 hours. Cell numbers were determined using the CyQUANT ${ }^{\circledR}$ DNA quantification kit (Invitrogen) with $50 \mu 1$ of cell lysate according to the manufacturer's protocol. Fluorescence at an excitation wavelength of $480 \mathrm{~nm}$ and an emission wavelength of $520 \mathrm{~nm}$ was measured using a Perkin Elmer Victor3 1420 Multilabel plate reader.

All data for metabolic activity and DNA assay was normalised to the dry weight of the corresponding scaffold.

\section{CELL MORPHOLOGY USING SEM}

On day 21, one sample from each group was cut into two halves and used for SEM analysis. The medium was removed and the scaffolds 
were washed twice with PBS and fixed in $10 \%$ formalin for one hour. After rinsing with PBS, the scaffolds were dehydrated in a series of increasing ethanol concentrations $(70 \%, 80 \%, 90 \%, 96 \%, 100 \% \times 2), 15$ minutes in each concentration, before drying in a critical point dryer (Balzers CPD-030). The samples were then sputter coated with gold (Cressington) for observation using the SEM.

\section{RNA ISOLATION AND GENE EXPRESSION ANALYSIS USING QUANTITATIVE PCR}

To analyse the expression of osteogenic markers by hMSCs, total RNA was isolated using a combination of the TRIzol ${ }^{\circledR}$ method with the NucleoSpin ${ }^{\circledR R N A}$ II isolation kit (Bioké). Briefly, scaffolds $(n=3)$ were washed with PBS once and $1 \mathrm{ml}$ of TRIzol reagent (Invitrogen) was added to the samples. After five minutes, the samples were stored at $-80{ }^{\circ} \mathrm{C}$ for RNA isolation. After chloroform addition and phase separation by centrifugation, the aqueous phase containing the RNA was collected, mixed with equal volume of $75 \%$ ethanol and loaded onto the RNA binding column of the kit. Subsequent steps were in accordance with the manufacturer's protocol. RNA was collected in RNAse-free water. The quality and quantity of RNA was analyzed by gel electrophoresis and spectrophotometry. Seven hundred fifty nanograms of RNA were used for first strand cDNA synthesis using iScript (Bio-Rad) according to the manufacturer's protocol. One $\mu 1$ of undiluted cDNA was used for subsequent analysis. PCR was performed on an iQ5 real time PCR machine (Bio rad) using SYBR Green supermix (Bio rad). Expression of osteogenic marker genes was normalised to GAPDH (5'- CGCTCTCTGCTCCTCCTGTT- 3' and 5'-CCATGGTGTCTGAGCGATGT -3')) levels and fold inductions were calculated using the comparative $\Delta \mathrm{CT}$ method [27]. The following primer sequences were used for the osteogenic marker genes: Bone Sialoprotein (BSP) (5'-TGCCTTGAGCCTGCTTCC-3' and 5'-CAAAATTAAAGCAGTCTTCATTTTG-3'), Osteopontin (OP) (5',-CCAAGTAAGTCCAACGAAAG-3 and 5'-GGTGATGTCCTCGTCTGTA-3') and Alkaline Phosphatase (ALP) (5'-GACCCTTGACCCCCACAAT-3' and 5'-GCTCGTACTGCATGTCCCCT-3'). For amplification of Bone Morphogenetic Protein-2 (BMP-2), a gene-specific primer mix was used (SA Biosciences), according to the manufacturer's protocol. 


\section{STATISTICAL ANALYSIS}

One way ANOVA with Tukey's multiple comparison post-hoc test was performed. The level of significance was set at 0.05 . All data presented are expressed as mean \pm standard deviation. Only significant differences between different scaffold groups in the same media or the same scaffold type in different media are shown.

\section{RESULTS}

\section{FABRICATION AND CHARACTERISATION OF SCAFFOLDS}

R P using 3DF was shown to be a suitable technique for fabricating R polymeric and composite 3D scaffolds. An SEM image of rapid prototyped $3 \mathrm{DF}$ and $3 \mathrm{DF}-\mathrm{HA}$ scaffolds in top view and cross section is presented in figure 1. Strands of the scaffolds appeared to decrease in thickness while being deposited, possibly due to the large fibre spacing. Fibre diameter, layer thickness and fibre spacing were calculated to be $0.315 \pm 0.1 \mathrm{~mm}, 0.221 \pm 0.02 \mathrm{~mm}, 1.96 \pm 0.13 \mathrm{~mm}$ and $0.34 \pm$ $0.08 \mathrm{~mm}, 0.238 \pm 0.03 \mathrm{~mm}, 1.84 \pm 0.03 \mathrm{~mm}$ for the 3DF and 3DF-HA scaffolds respectively. The porosities of the $3 \mathrm{DF}$ and $3 \mathrm{DF}-\mathrm{HA}$ scaffolds were determined to be $81.9 \%$ and $79.3 \%$ respectively. In order to confirm the presence of HA in the 3DF-HA composite, EDX analysis was performed. The EDX spectrum corresponding to the region of interest (Figure 1E) is shown in figure $1 \mathrm{~F}$ and indicated the presence of $\mathrm{Ca}$ and $\mathrm{P}$ peaks.

The assembled composites were fabricated by inserting the ceramic pillars into the 3DF scaffolds. Figure 2A shows the optical images of various configurations in which HA pillars can be assembled into 3DF scaffolds. For experiments, the weight of the incorporated HA pillars was kept to $15 \%$ of the total weight (configuration similar to the image on the left in 2A) of the construct to ensure that equal amounts of HA were incorporated in the assembled and conventional composite scaffolds. Figure 2B shows the SEM micrograph of the assembled composite with the ceramic pillar in the middle. The structure of the HA particles is shown in $2 \mathrm{C}$ and $2 \mathrm{D}$. The grain size of the HA ceramic was between 0.8 to $1.5 \mu \mathrm{m}$ as measured on the SEM images. The XRD pattern (Figure 2E) confirmed the presence of fully crystalline phase 
pure HA.

The results of the mechanical testing are shown in figure 3. The incorporation of HA in the scaffold bulk has impacted the scaffold stiffness. The Young's modulus of 3DF-HA scaffolds $(39 \pm 15 \mathrm{MPa})$ was signifi-
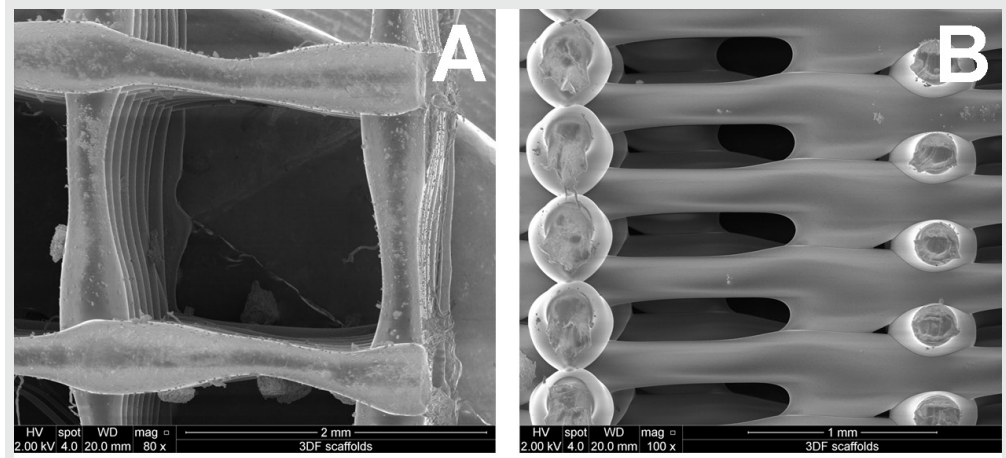

Figure 1: Conventional rapid prototyping (RP) for fabrication of polymeric and composite scaffolds. (A) SEM image of a $3 D F$
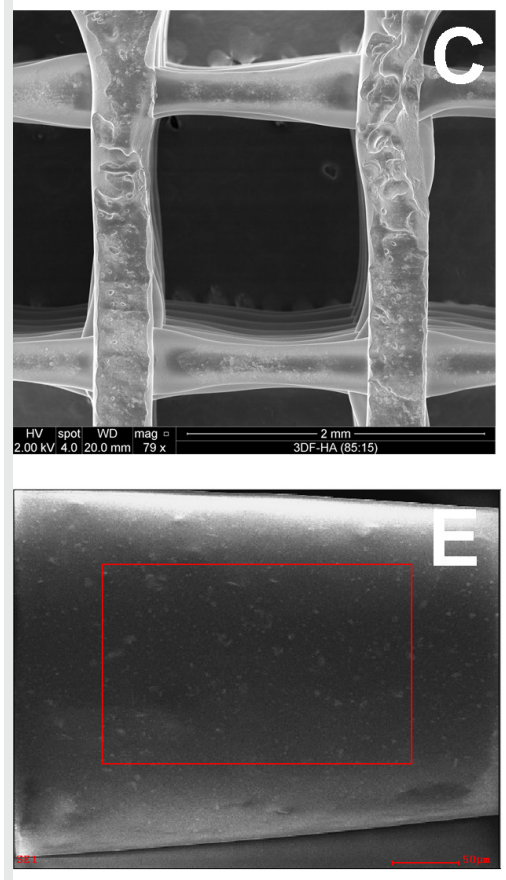

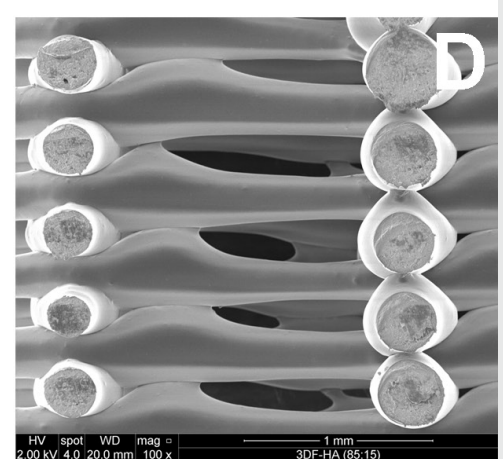

scaffold fabricated by RP (B) Cross section of $3 D F$ scaffold (C) SEM image of monolithic polymer ceramic composite (3DF-HA), (D) Cross section of 3DF-HA composite. ( $E$ and $F)$ High magnification of 3DF-HA scaffold strut and EDX spectrum with $\mathrm{Ca}$ and $P$ peaks. Scale bars A, $C-2 m m, B, D$ - $1 \mathrm{~mm}, E-50 \mu \mathrm{m}$

cantly higher than that of the other two scaffold groups. The addition of HA as pillars increased the modulus of the assembled construct (9 $\pm 4.5 \mathrm{MPa})$ compared to the $3 \mathrm{DF}$ scaffold $(8.1 \pm 2.4 \mathrm{MPa})$ but this in- 
crease was minimal.

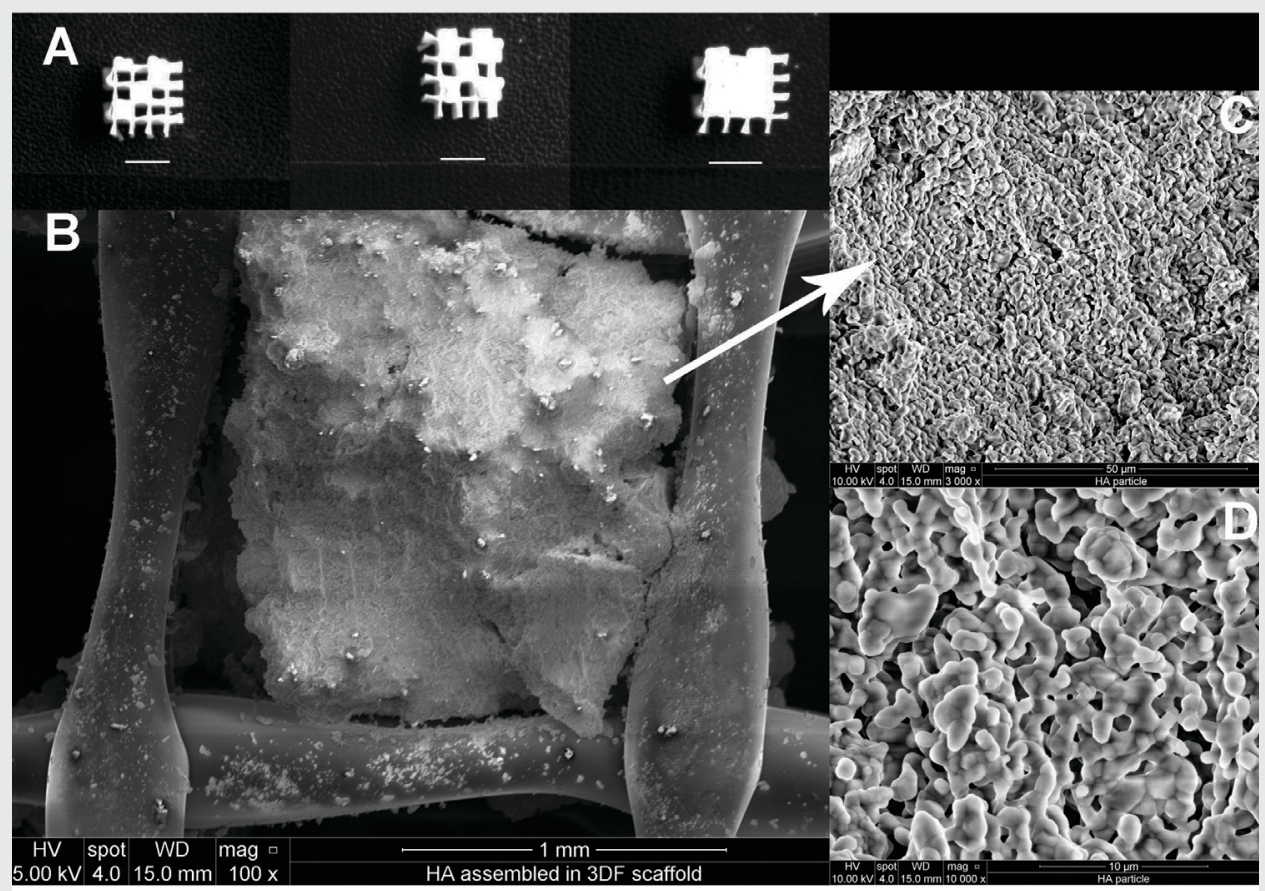

\section{E}

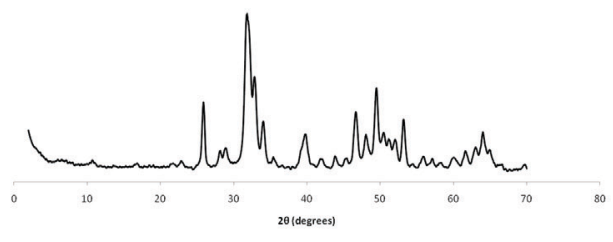

Figure 2: Assembled polymer ceramic composite fabricated using rapid prototyping and stereolithography. (A) shows photographs of assembled composites with different amounts of HA (fabricated using a negative stereolithography mould) loaded on a 3DF polymer scaffold fabricated by rapid prototyping (scale bar $5 \mathrm{~mm}$ ). (B) SEM image of an assembled scaffold with a HA pillar in one of the pores (scale bar - $1 \mathrm{~mm}$ ).(C,D) Microstructure of HA at different magnifications (scale bar $50 \mu \mathrm{m}$ and $10 \mu \mathrm{m}$ respectively). (E) XRD pattern of the HA particles

Release of calcium and phosphate from 3DF, 3DF-HA and HA pillars was assessed (Figure 4). One sample from the HA pillars was excluded from analysis of calcium concentration owing to a very high standard deviation. No calcium was released from the rapid prototyped composite whereas the calcium concentration released from HA after 21 days 


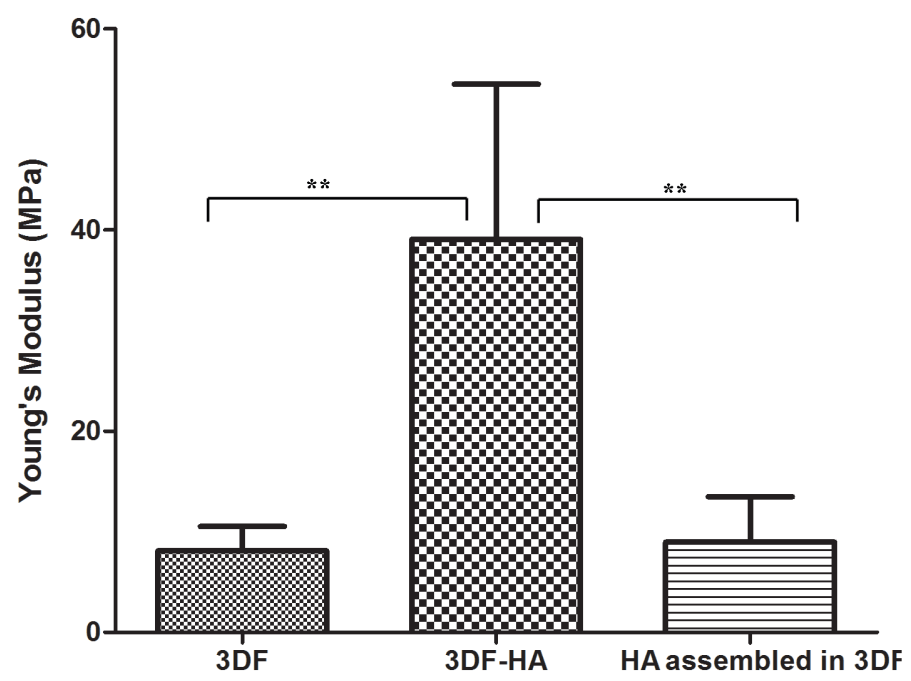

Figure 3: Mechanical characterisation of scaffolds. 3DF, 3DF-HA and HA assembled in $3 D F$ scaffolds were mechanically characterised using a compression test. The figure above presents the Young's modulus during compression. The modulus of 3DF-HA scaffolds was highly significant $(p<0.01)$ compared to the $3 D F$ and assembled composites

\section{Calcium and phosphate release}

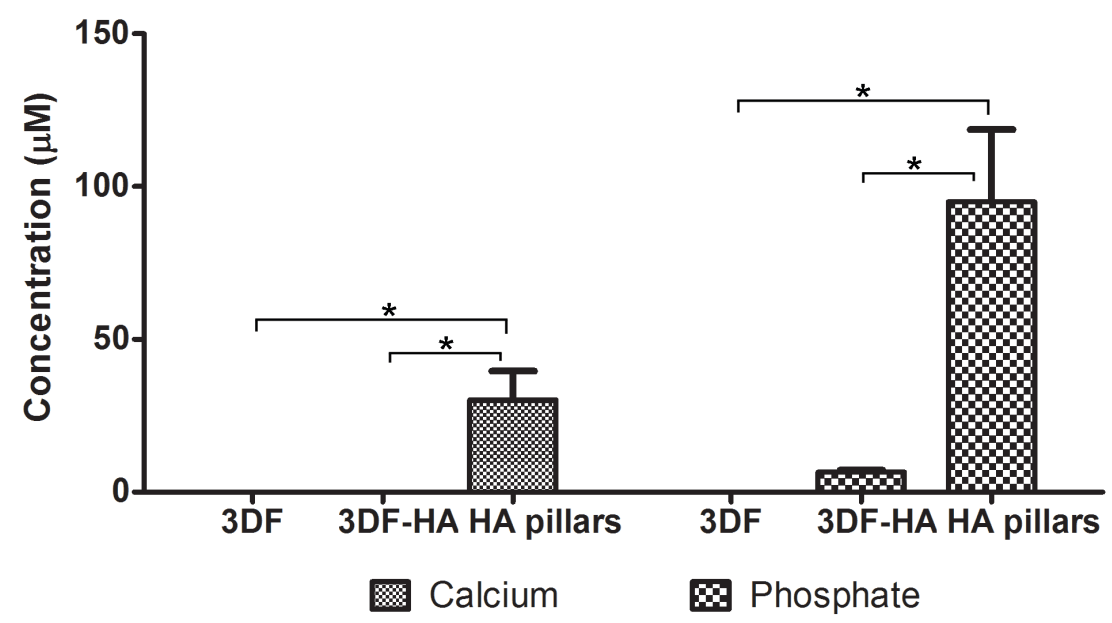

Figure 4: Release of calcium and phosphate from various scaffolds in simulated physiological solution for 21 days. * represents statistically significant differences , $p<0.05$ 
was $30.2 \pm 9.4 \mu \mathrm{M}$. Phosphate release from the pillars $(95.1 \pm 23.6$ $\mu \mathrm{M})$ was also significantly higher compared to the release from the rapid prototyped composite $(6.6 \pm 0.6 \mu \mathrm{M})$.

\section{METABOLIC ACTIVITY AND DNA AMOUNTS}

A

Day 11

政

B
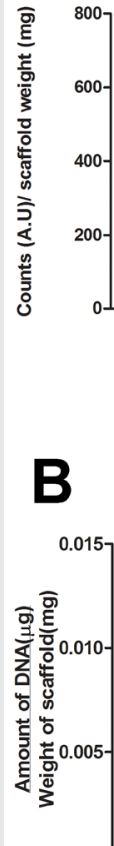

Amount of DNA after 21 days

\section{Metabolic activity of hMSCs}

Day 21

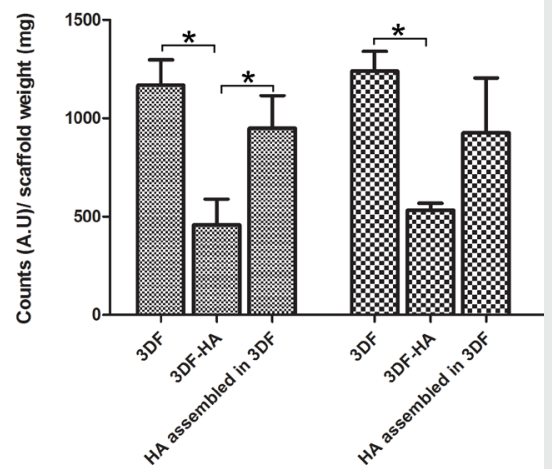

$m$ Basic

$\infty$ Mineralisation

Figure 5: (A) Metabolic activity of hMSCs seeded on different scaffolds in basic and mineralisation media on days 11 and 21 measured using Alamar Blue assay. * represents statistically significant differences with $p<0.05$. (B) Amount of DNA after 21 days on different scaffolds in basic and mineralisation media as measured using CyQuant assay. Data are represented as mean \pm standard deviation

Alamar blue assay was performed on days 11 and 21 to assess the 

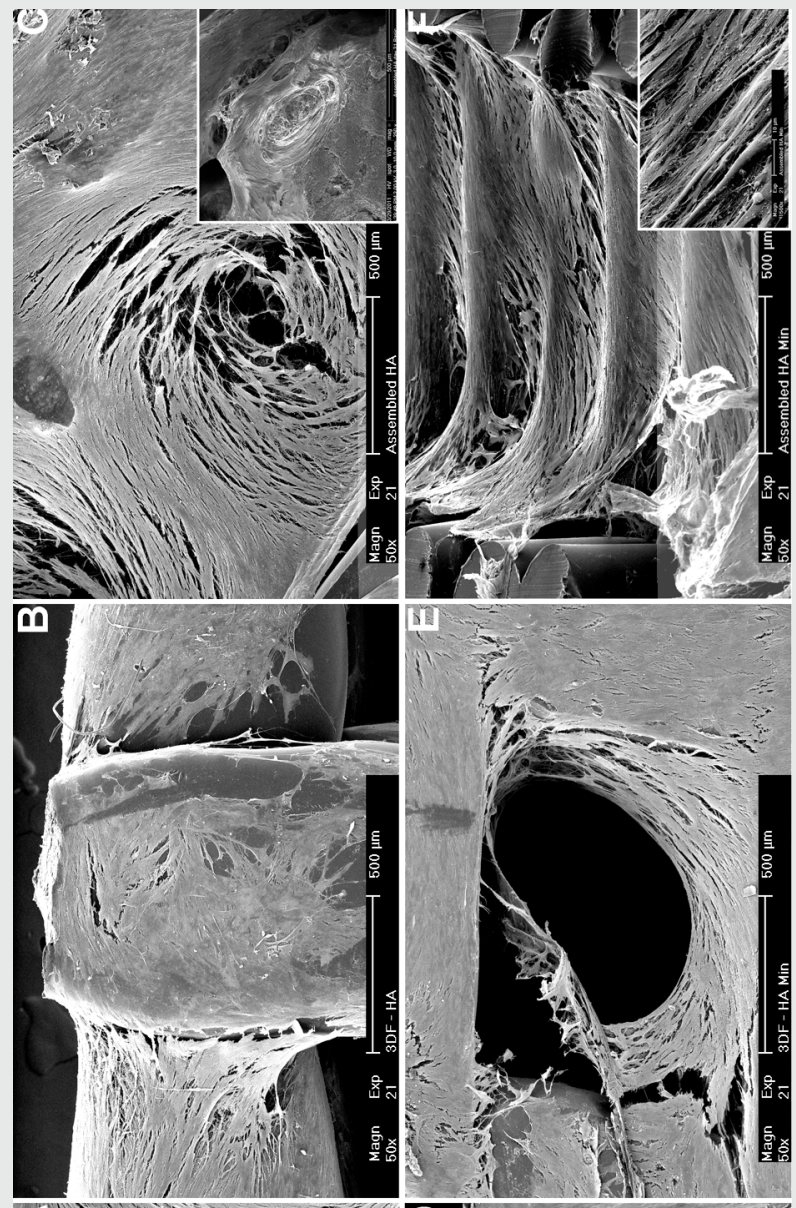

Figure 6: Cell morphology on scaffolds after 21 days. (A-C) represent $3 D F, 3 D F-H A$ and assembled $H A$ scaffolds in basic medium. Inset in $C$ shows hMSCs attached on HA pillars (Scale bar - $500 \mu \mathrm{m})$. (D-F) $3 D F, 3 D F-H A$ and assembled $H A$ scaffolds in mineralisation medium. Scale bar - $500 \mu \mathrm{m}$. Inset in F shows hMSCS along with produced ECM (Scale bar-
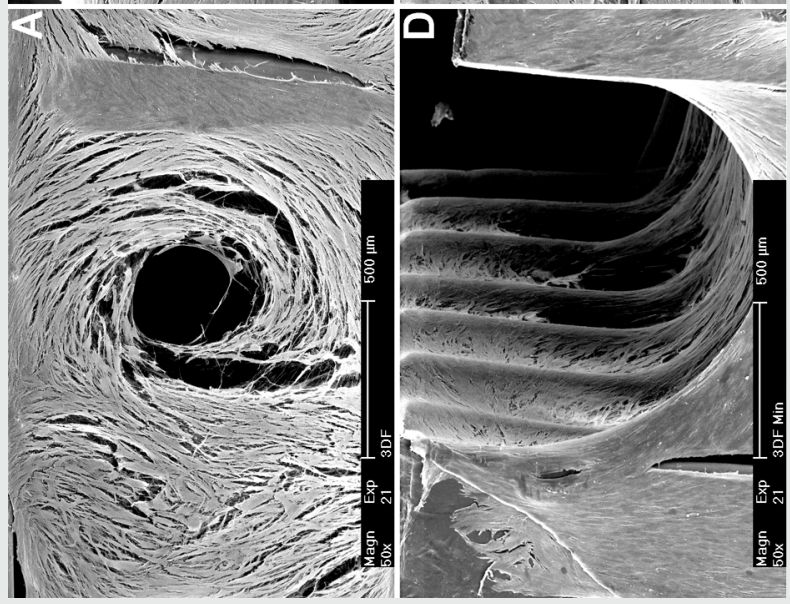
$10 \mu \mathrm{m})$ 
cell metabolism in the various scaffolds (Figure 5A). On day 11, no significant differences in cell metabolism were observed among the different scaffold groups irrespective of culture medium. On day 21, in basic medium, cells cultured on 3DF-HA composites had a significantly lower metabolic activity when compared to 3DF and assembled composites. The same trend was observed in mineralisation medium although statistically significant differences were observed only between 3DF and 3DF-HA groups.

A quantitative biochemical assay to determine the amount of DNA in different scaffolds was performed after 21 days (Figure 5B). No significant differences due to effect of culture medium or scaffold type were observed although a trend similar to the metabolic activity was observed with 3DF-HA scaffolds having the lowest amount of DNA in both media among the different scaffold groups.

\section{CEll MORPhOlOGY AND Distribution USING SEM}

SEM images after 21 days (Figure 6) show cell attachment on the different scaffolds. Qualitative SEM analyses indicated a lower number of cells in the 3DF-HA scaffolds as compared to the other two groups. Inset at the top right (Figure 6) shows cells present on the inserted HA pillars. Cell attachment was observed in the different layers of the scaffolds suggesting that they penetrated to the deeper layers. Cells also produced their own fibrillar matrix as confirmed by SEM (inset lower right, Figure 6).

\section{GENE EXPRESSION ANALYSIS USING QUANTITATIVE PCR}

The gene expression of different osteogenic markers was analysed using quantitative RT-PCR and the results are shown in figure 7. Only statistical significances due to scaffold composition or arrangement have been shown in the figure. Cells on 3DF scaffolds in basic medium showed basal level of BSP expression which was significantly higher compared to the 3DF-HA scaffolds. In mineralisation medium, 3DFHA scaffolds showed basic expression whereas BSP was upregulated in 3DF scaffolds and assembled composites. ALP expression of cells on 3 DF scaffolds in basic medium was also at basal levels while it was downregulated in both composites (significant for the assembled com- 


\section{Gene expression of osteogenic markers after 21 days}
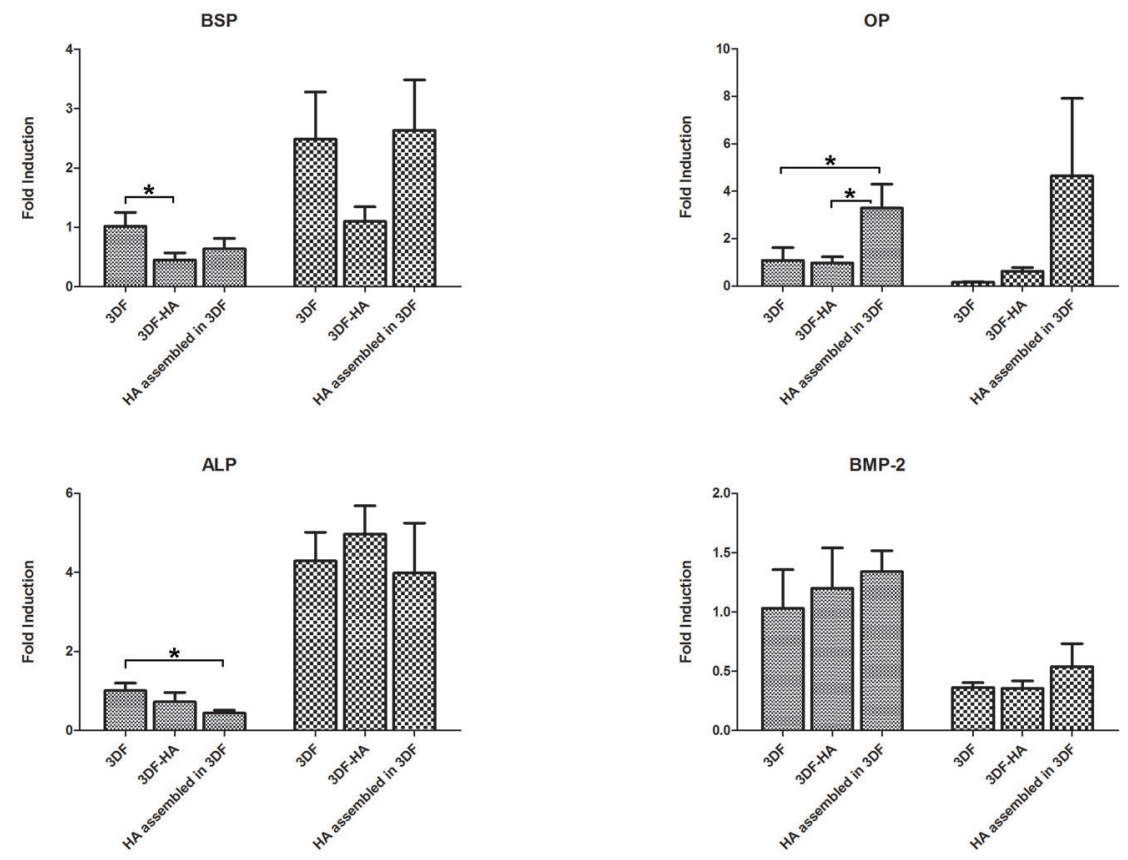

Basic

$\infty$ Mineralisation

Figure 7: qPCR analysis for osteogenic panel of genes after 21 days in culture. * represents statistically significant differences , $p<0.05$. Data are represented as mean \pm standard deviation

posite). In mineralisation medium, ALP was upregulated in all scaffold groups. Cells on assembled composite scaffolds showed a significantly higher upregulation of OP in basic medium compared to the 3DF and 3DF-HA scaffolds. Upregulation of gene expression was also observed in mineralisation medium although no statistical differences were observed. In case of BMP-2, the trend in expression level was 3DF < 3DF-HA $<$ Assembled composite although no significant differences were observed.

\section{DISCUSSION}

Three dimensional composite scaffolds containing PA and HA were 1 fabricated using two different approaches. The conventional approach to fabricate composite scaffolds by using polymer-HA compos- 
ite filaments was successful only up to $15 \mathrm{wt}$ \% loading of HA. Above this amount, it was impossible to fabricate $3 \mathrm{D}$ scaffolds with the current choice of nozzles and the equipment due to clogging by the ceramic particles and consequent increase in the viscosity of the molten blend. The amount of ceramic that could be loaded in the present study was comparable to the amount in the study by Lam et al. [28] who succeeded at preparing a $\beta$-TCP -PCL composite with a ceramic content of $20 \mathrm{wt} . \%$ by fused deposition modelling. Using a precision extrusion process, Shor and co-workers [19] obtained a maximum loading of 25 wt. \% HA in PCL. Higher loading amounts of ceramic are possible using solvent casting methods [29], but these involve the use of, possibly cytotoxic organic solvents. Besides, the scaffolds produced using solvent casting often lack close control over porosity and architecture. In this regard, the assembly approach is innovative and versatile. As shown in figure $2 \mathrm{a}$, different amounts of HA can be loaded on to scaffolds without the problems associated with processing of high ceramic amounts and the need for complex extrusion systems.

Compression tests performed to evaluate the stiffness of the scaffold showed that the addition of HA in the bulk increased the stiffness by almost 5 times compared to 3DF polymer only scaffolds. This result was to be expected since, in an in vivo setting, the mineral component of bone imparts stiffness. In a previous study [21], assembled composites with different shapes of a biphasic calcium phosphate (BCP - $75.4 \%$ HA and $24.6 \% \beta$-TCP) particles were inserted into $3 \mathrm{DF}$ scaffolds and an increase in bending storage modulus and compressive storage modulus were observed as compared to the 3DF scaffolds during dynamic mechanical analysis. In the current study, no significant increase in modulus was observed due to the insertion of HA particles. One possible reason could be the different loading of the ceramic particles. In the earlier study [21], BCP particles formed about $60 \%$ of the scaffold weight while only $15 \%$ by weight of HA was used in the present study. In a review on mechanical properties of calcium phosphates and composites [30], it was observed that bulk properties of HA and BCP were spread across two orders of magnitude (Compressive strength 5 - $500 \mathrm{MPa}$ ). It was described that, in general, $\beta$ - TCP possesses lower strength and other mechanical properties. Therefore, it can be reasonably stated that, if the same amount of HA was used instead of BCP, the resulting scaffolds would have had comparable or 
better mechanical properties. While the conventional composites ( $40 \mathrm{MPa}$ ) had a modulus above the minimum range stated for cancellous bone (12 $\mathrm{MPa})$ [31], the polymeric and assembled composites fell slightly short (8-9 MPa). However, it is possible to further increase the modulus of the assembled composite scaffolds by increasing the loading of HA particles as insertion of more ceramic particles has been shown to lead to higher values [21]. This adds another interesting facet to the assembly based fabrication approach - the differential loading of ceramic particles to tune scaffold stiffness.

Cells attached and proliferated on all scaffold types in both basic and mineralisation medium. Cells also penetrated the interior of the scaffolds and started producing their own matrix. After 21 days, cells cultured on 3DF-HA composites showed the lowest proliferation and DNA amounts as shown by Alamar blue and DNA assays. Wilmowsky and co-workers [32], in their study with different polyetheretherketone (PEEK) based composites fabricated by SLS, observed that human foetal osteoblasts cultured on the composites containing $10 \mathrm{wt} \%$ $\beta$-TCP showed the least pronounced proliferation and viability. They suggested that calcium phosphate compounds around the chosen concentration do not have a favourable effect on osteoblast proliferation in vitro. Zhou et al. [33] showed a more pronounced attachment of human alveolar osteoblasts on PCL-TCP rapid prototyped composites compared to PCL scaffolds and attributed this observation to increased hydrophilicity of the composite scaffolds along with the ability of TCP to adsorb more proteins. Due to the contradictory results observed in different experimental setups, it is difficult to pinpoint the exact effect of HA addition to a polymeric scaffold on cell proliferation. The resultant biological properties of the composites are influenced by the release of calcium and phosphate ions from the ceramic which is a function of the amount of ceramic present, the phase of the ceramic and the degradation behaviour of the ceramic and the polymer.

The release studies showed that HA pillars were the only scaffolds to release calcium and a significantly high amount of phosphate was also present. Hence, for an assembled composite with 15\% HA, it is plausible to expect the ionic concentrations to be at most $15 \%$ of the observed values for HA pillars leading to calcium and phosphate concentrations of $5 \mu \mathrm{M}$ and $14 \mu \mathrm{M}$ approximately. The dissolution, followed 
by subsequent release of constituent ions is considered the source of bioactivity of Ca-P ceramics [34]. Gene expression and differentiation have been modulated by controlling the ionic concentrations. Tada et al. [35] showed that an extracellular [Ca 2+] of $10 \mathrm{mM}$ leads to a 25 fold upregulation in BMP-2 gene expression in dental pulp cells while mRNA expression and secretion of BMP-2 was significantly increased in a macrophage cell line for [Ca 2+] of $14 \mathrm{mM} \mathrm{[36].} \mathrm{In} \mathrm{both} \mathrm{studies,}$ no differences in BMP-2 expression were observed at concentrations lower than $3 \mathrm{mM}$. In the current study, although BMP-2 expression of the composites suggests an increasing trend in correlation to the calcium release, no significant upregulation was observed indicating that the $[\mathrm{Ca} 2+]$ may have been below the necessary threshold. OP, a phosphorylated acidic glycoprotein is synthesised by osteoblasts in vitro and is found in mineralised tissue. OP regulates the attachment of osteoblasts and osteoclasts to the ECM [37-38]. Assembled composites in basic and mineralisation medium showed the highest amount of OP expression ( $>5$ fold) amongst the different scaffolds tested. Previous studies using sintered calcium phosphate ceramics [39] and calcium phosphate coated 3D scaffolds prepared from PA (unpublished) also showed a very high expression of OP compared to tissue culture plastic and non coated scaffolds respectively. The presence of calcium phosphates enhances OP gene expression clearly. Using MC3T3-E1 cells, Beck and co workers [37] observed that OP gene expression was induced by the presence of phosphate, which is a result of hydrolysis of $\beta$-glycerol phosphate, an additive used in cell culture media to induce mineralisation. Hence, the high expression of OP in the assembled scaffolds could be attributed to the increased availability of phosphates in the culture medium. Conventional composites fabricated by extruding composite filaments would lead to distributed HA particles in the whole scaffold, implying that not all of the HA is present on the surface and ready available. In contrast, assembled composites with inserted HA pillars present a larger contact surface to media leading to a potentially faster dissolution and release of ions. This was confirmed by the release study in a simulated physiological solution that mimics the in vivo situation. To further increase the rate of dissolution, calcium phosphate ceramics with a higher degradation rate, such as TCP could be chosen instead of the conventional HA.

The use of polymer ceramic composites for bone tissue engineering has 
been the subject of various in vitro and in vivo studies [14, 29, 32-33, 40-43]. RP techniques have become prominent in the recent years due to their versatile nature and their ability to control scaffold properties. Apart from the conventional RP method of fabricating composites, we have presented an alternative way of assembling composites offering more freedom in design of scaffold properties and the possibility of influencing cellular response by altering the loading of ceramic material.

\section{CONCLUSIONS}

Two different strategies for fabrication of three dimensional poly1 mer-ceramic composite scaffolds have been studied. The conventional approach led to a mechanically stiffer construct compared to the assembled composite. The release study demonstrated that a higher amount of calcium and phosphate is released from the pillars probably due to better availability of the ceramic in the pillars compared to the extruded composite. hMSCs had higher metabolic activity on the assembled composite compared to the conventional composite while no significant differences were observed in DNA amounts. The expression of osteogenic genes was generally higher on assembled than conventional composite scaffolds. Based on the above results, the assembly approach to fabricate composites with the possibility of tuning mechanical properties and modulating cellular response by varying the amount of $\mathrm{Ca}-\mathrm{P}$ ceramic without processing difficulties might be an attractive strategy for bone tissue engineering applications.

\section{ACKNOWLEDGEMENTS}

The authors wish to thank Ms. Charlene Danoux for assistance with 1 the XRD measurements, Dr. Huipin Yuan, Mr. Davide Barbieri for providing the HA powder and assistance with the preparation of ceramic pillars, Ms. Zeinab Tahmasebi Birgani for the release study and Ms. Anita Podt for the preparation of moulds by stereolithography.

\section{REFERENCES}

1. Augat P, Schorlemmer S. The role of cortical bone and its microstructure in bone strength. Age Ageing 2006;35 Supp1 2:ii27-ii31. 
2. Fratzl P, Gupta HS, Paschalis EP, Roschger P. Structure and mechanical quality of the collagen-mineral nano-composite in bone. $\mathrm{J}$ Mater Chem 2004;14(14):2115-2123.

3. Laurencin C, Khan Y, El-Amin SF. Bone graft substitutes. Expert Rev Med Devic 2006;3(1):49-57.

4. Kainer MA, Linden JV, Whaley DN, Holmes HT, Jarvis WR, Jernigan DB, et al. Clostridium infections associated with musculoskeletal-tissue allografts. New Engl J Med 2004;350(25):2564-2571.

5. Mroz TE, Joyce MJ, Steinmetz MP, Lieberman IH, Wang JC. Musculoskeletal allograft risks and recalls in the United States. J Am Acad Orthop Surg 2008;16(10):559-565.

6. Wahl DA, Czernuszka JT. Collagen-hydroxyapatite composites for hard tissue repair. Eur Cell Mater 2006;11:43-56.

7. Zhang $\mathrm{P}$, Hong $\mathrm{Z}$, Yu T, Chen $\mathrm{X}$, Jing X. In vivo mineralization and osteogenesis of nanocomposite scaffold of poly(lactide-coglycolide) and hydroxyapatite surface-grafted with poly(L-lactide). Biomaterials 2009;30(1):58-70.

8. Kim HW, Lee HH, Knowles JC. Electrospinning biomedical nanocomposite fibers of hydroxyapatite/poly(lactic acid) for bone regeneration. J Biomed Mater Res A 2006;79(3):643-649.

9. Montjovent MO, Mathieu L, Hinz B, Applegate LL, Bourban PE, Zambelli PY, et al. Biocompatibility of bioresorbable poly(L-lactic acid) composite scaffolds obtained by supercritical gas foaming with human fetal bone cells. Tissue Eng 2005;11(11-12):1640-1649.

10. Yefang Z, Hutmacher DW, Varawan SL, Meng LT. Comparison of Human alveolar osteoblasts cultured on polymer-ceramic composite scaffolds and tissue culture plates. Int J Oral Max Surg 2007;36(2):137145 .

11. Yang F, Both SK, Yang X, Walboomers XF, Jansen JA. Development of an electrospun nano-apatite/PCL composite membrane for GTR/GBR application. Acta Biomater 2009;5(9):3295-3304.

12. Aboudzadeh N, Imani M, Shokrgozar MA, Khavandi A, Javadpour J, Shafieyan Y, et al. Fabrication and characterization of poly(D,Llactide-co-glycolide)/hydroxyapatite nanocomposite scaffolds for 
bone tissue regeneration. J Biomed Mater Res A 2010;94(1):137-145.

13. Jose MV, Thomas V, Johnson KT, Dean DR, Nyairo E. Aligned PLGA/HA nanofibrous nanocomposite scaffolds for bone tissue engineering. Acta Biomater 2009;5(1):305-315.

14. Laschke MW, Strohe A, Menger MD, Alini M, Eglin D. In vitro and in vivo evaluation of a novel nanosize hydroxyapatite particles/ poly(ester-urethane) composite scaffold for bone tissue engineering. Acta Biomater 2010;6(6):2020-2027.

15. Huang YX, Ren J, Chen C, Ren TB, Zhou XY. Preparation and properties of poly(lactide-co-glycolide) (PLGA)/ nano-hydroxyapatite (NHA) scaffolds by thermally induced phase separation and rabbit MSCs culture on scaffolds. J Biomater Appl 2008;22(5):409-432.

16. Peltola SM, Melchels FP, Grijpma DW, Kellomaki M. A review of rapid prototyping techniques for tissue engineering purposes. Ann Med 2008;40(4):268-280.

17. Duan B, Wang M, Zhou WY, Cheung WL, Li ZY, Lu WW. Threedimensional nanocomposite scaffolds fabricated via selective laser sintering for bone tissue engineering. Acta Biomater 2010;6(12):44954505 .

18. Tan KH, Chua CK, Leong KF, Cheah CM, Cheang P, Abu Bakar MS, et al. Scaffold development using selective laser sintering of polyetheretherketone-hydroxyapatite biocomposite blends. Biomaterials 2003;24(18):3115-3123.

19. Shor L, Guceri S, Wen XJ, Gandhi M, Sun W. Fabrication of three-dimensional polycaprolactone/hydroxyapatite tissue scaffolds and osteoblast-scaffold interactions in vitro. Biomaterials 2007;28(35):5291-5297.

20. Woodfield TBF, Malda J, de Wijn J, Peters F, Riesle J, van Blitterswijk CA. Design of porous scaffolds for cartilage tissue engineering using a three-dimensional fiber-deposition technique. Biomaterials 2004;25(18):4149-4161.

21. Moroni L, Hamann D, Paoluzzi L, Pieper J, de Wijn JR, van Blitterswijk CA. Regenerating articular tissue by converging technologies. Plos One 2008;3(8):e3032. 
22. Du C, Meijer GJ, van de Valk C, Haan RE, Bezemer JM, Hesseling $\mathrm{SC}$, et al. Bone growth in biomimetic apatite coated porous Polyactive $((\mathrm{R}))$ 1000PEGT70PBT30 implants. Biomaterials 2002;23(23):4649-4656.

23. Nandakumar A, Fernandes H, de Boer J, Moroni L, Habibovic $\mathrm{P}$, van Blitterswijk CA. Fabrication of bioactive composite scaffolds by electrospinning for bone regeneration. Macromol Biosci 2010;10(11):1365-1373.

24. Moroni L, de Wijn JR, van Blitterswijk CA. 3D fiber-deposited scaffolds for tissue engineering: influence of pores geometry and architecture on dynamic mechanical properties. Biomaterials 2006;27(7):974-985.

25. Landers R, Pfister A, Hubner U, John H, Schmelzeisen R, Mulhaupt R. Fabrication of soft tissue engineering scaffolds by means of rapid prototyping techniques. J Mater Sci 2002;37(15):3107-3116.

26. Both SK, Van der Muijsenberg AJC, Van Blitterswijk CA, De Boer J, De Bruijn JD. A rapid and efficient method for expansion of human mesenchymal stem cells. Tissue Eng 2007;13(1):3-9.

27. Livak KJ, Schmittgen TD. Analysis of relative gene expression data using real-time quantitative PCR and the 2(-Delta Delta C(T)) Method. Methods 2001;25(4):402-408.

28. Lam CXF, Teoh SH, Hutmacher DW. Comparison of the degradation of polycaprolactone and polycaprolactone-(beta-tricalcium phosphate) scaffolds in alkaline medium. Polym Int 2007;56(6):718728.

29. Cao H, Kuboyama N. A biodegradable porous composite scaffold of PGA/beta-TCP for bone tissue engineering. Bone 2010;46(2):386395.

30. Wagoner Johnson AJ, Herschler BA. A review of the mechanical behavior of $\mathrm{CaP}$ and $\mathrm{CaP} /$ polymer composites for applications in bone replacement and repair. Acta Biomater 2011;7(1):16-30.

31. Athanasiou KA, Zhu CF, Lanctot DR, Agrawal CM, Wang X. Fundamentals of biomechanics in tissue engineering of bone. Tissue Eng 2000;6(4):361-381. 
32. von Wilmowsky C, Vairaktaris E, Pohle D, Rechtenwald T, Lutz $\mathrm{R}$, Munstedt $\mathrm{H}$, et al. Effects of bioactive glass and beta-TCP containing three-dimensional laser sintered polyetheretherketone composites on osteoblasts in vitro. J Biomed Mater Res A 2008;87A(4):896-902.

33. Zhou YF, Hutmacher DW, Varawan SL, Lim TM. In vitro bone engineering based on polycaprolactone and polycaprolactone-tricalcium phosphate composites. Polym Int 2007;56(3):333-342.

34. Ducheyne P, Beight J, Cuckler J, Evans B, Radin S. Effect of Calcium-Phosphate Coating Characteristics on Early Postoperative Bone Tissue Ingrowth. Biomaterials 1990;11(8):531-540.

35. Tada H, Nemoto E, Kanaya S, Hamaji N, Sato H, Shimauchi H. Elevated extracellular calcium increases expression of bone morphogenetic protein-2 gene via a calcium channel and ERK pathway in human dental pulp cells. Biochem Biophys Res Commun 2010;394(4):10931097.

36. Honda Y, Anada T, Kamakura S, Nakamura M, Sugawara S, Suzuki O. Elevated extracellular calcium stimulates secretion of bone morphogenetic protein 2 by a macrophage cell line. Biochem Biophys Res Commun 2006;345(3):1155-1160.

37. Beck GR, Zerler B, Moran E. Phosphate is a specific signal for induction of osteopontin gene expression. P Natl Acad Sci USA 2000;97(15):8352-8357.

38. Roach HI. Why Does Bone-Matrix Contain Noncollagenous Proteins - the Possible Roles of Osteocalcin, Osteonectin, Osteopontin and Bone Sialoprotein in Bone Mineralization and Resorption. Cell Biol Int 1994;18(6):617-628.

39. Yuan H, Fernandes H, Habibovic P, de Boer J, Barradas AM, de Ruiter A, et al. Osteoinductive ceramics as a synthetic alternative to autologous bone grafting. Proc Natl Acad Sci U S A 2010;107(31):1361413619 .

40. Causa F, Netti PA, Ambrosio L, Ciapetti G, Baldini N, Pagani $\mathrm{S}$, et al. Poly-epsilon-caprolactone/hydroxyapatite composites for bone regeneration: in vitro characterization and human osteoblast response. J Biomed Mater Res A 2006;76A(1):151-162.

41. Heo SJ, Kim SE, Wei J, Hyun YT, Yun HS, Kim DH, et al. Fab- 
rication and characterization of novel nano- and micro-HA/PCL composite scaffolds using a modified rapid prototyping process. J Biomed Mater Res A 2009;89A(1):108-116.

42. Kim S, Kim SS, Lee SH, Eun Ahn S, Gwak SJ, Song JH, et al. In vivo bone formation from human embryonic stem cell-derived osteogenic cells in poly(d,l-lactic-co-glycolic acid)/hydroxyapatite composite scaffolds. Biomaterials 2008;29(8):1043-1053.

43. Taboas JM, Maddox RD, Krebsbach PH, Hollister SJ. Indirect solid free form fabrication of local and global porous, biomimetic and composite 3D polymer-ceramic scaffolds. Biomaterials 2003;24(1):181-194. 


\section{PART B}

\section{Surface modifications for altering cell behaviour}

"Life is like topography, Hobbes. There are summits of happiness and success, flat stretches of boring routine, and valleys of frustration and failure."

- Calvin and Hobbes 


\section{6}

Modulation of nanoscale surface roughness and chemistry by plasma treatment influences osteogenic differentiation of human mesenchymal stromal cells

Anandkumar Nandakumar ${ }^{\mathrm{a}}$, Diogo Santos ${ }^{\mathrm{a}, \mathrm{b}}$, Anouk Mentink ${ }^{\mathrm{a}}$, Nils Auffermann ${ }^{\mathrm{a}}$, Kees van der Werf ${ }^{\mathrm{C}}$, Martin Bennink ${ }^{\mathrm{c}}$, Lorenzo Moroni $^{\mathrm{a}}$, Clemens van Blitterswijk ${ }^{\mathrm{a}}$, Pamela Habibovic ${ }^{\mathrm{a}}$

${ }^{a}$ Department of Tissue Regeneration, MIRA Institute for Biomedical Technology and Technical Medicine, University of Twente, The Netherlands

${ }^{b}$ Escola Superior de Biotecnologia, Universidade Católica Portuguesa, Rua Dr. António Bernardino de Almeida, 4200-072 Porto, Portugal

${ }^{\mathrm{C}}$ Nanobiophysics, MESA+ Institute for Nanotechnology, University of Twente, PO Box 217, 7500 AE Enschede, The Netherlands 


\section{ABSTRACT}

Plasma treatment is expected to modify the physicochemical properties and surface morphology of materials, thereby improving interactions with cells. As physical cues on the surface of culture substrates have proved to alter cell behaviour, fibrous three-dimensional (3D) scaffolds mimicking the physical microenvironment of extra-cellular matrix were fabricated by electrospinning and treated with oxygen plasma for different times to create nanoscale roughness. Scanning electron microscopy (SEM) analysis revealed a fibre diameter of $5.49 \pm 0.96 \mu \mathrm{m}$ for as-spun meshes as well as an increase in surface roughness with increasing oxygen plasma exposure time. Atomic force microscopy measurements determined an exponential increase of surface roughness with treatment time. Contact angle measurements showed increased hydrophilicity after plasma treatment. This was associated to higher oxygen content in plasma treated scaffolds compared to untreated ones, as measured by X-ray photoelectron spectroscopy. Protein adsorption capacity of the different surfaces was quantified using bovine serum albumin (BSA) as a model protein. Scaffolds treated with plasma for 15 and 30 minutes showed a significantly higher protein adsorption compared to untreated fibres, treated fibres for less than 15 minutes and tissue culture poly (styrene). Human mesenchymal stromal cells (hMSCs) were cultured on untreated, 15 and 30 minute treated scaffolds for seven days in basic and osteogenic medium. Fluorescent staining and SEM confirmed cell attachment and a pronounced spindle-like morphology on all scaffolds. Amount of DNA, metabolic activity, and alkaline phosphatase (ALP) production were analysed and no significant differences were observed between different scaffolds. Expression of different osteogenic markers was measured using quantitative PCR and showed significant upregulation of bone sialoprotein (BSP) and osteonectin (ON) expression on oxygen plasma treated fibres compared to untreated fibres, suggesting that oxygen plasma treatment might be used to initiate hMSCs osteogenic differentiation. 


\section{INTRODUCTION}

$\mathbf{R}$ ecreating the native milieu of cells by providing structural cues Rusing scaffolds is an attractive strategy in tissue engineering. One of the widely used approaches to create a natural extra-cellular matrixlike environment is the use of electrospun scaffolds [1]. Non-woven electrospun fibrous meshes are produced by applying a high voltage to a polymer solution [2] or melt [3]. The polymer is pulled through a nozzle due to the influence of the electric field and deposited on a grounded collector while most of the solvent evaporates during the spinning process. By varying process parameters like flow rate, voltage, solvent, air gap and environmental conditions (temperature, relative humidity), scaffolds of different diameters, porous network and physicochemical properties can be obtained [2-7]. Due to the versatile nature of the process, electrospun matrices have found widespread use as scaffolds to engineer a variety of tissues like skin [8], nerve [9], cartilage [10-12] and bone [13-15] and also as a delivery device for drugs, proteins and growth factors $[1,13,16]$.

Surface treatment of scaffolds is performed to improve scaffold characteristics such as hydrophilicity, protein adsorption and increased cell attachment. Modulation of topography in the micro- to nanoscale range by changing roughness, size and shape has been known to alter the response of osteoblasts. Brett and co-workers, for example, demonstrated that the surface roughness of titanium altered gene expression profiles of alveolar bone cells [17]. Furthermore, Boyan et al. [18] showed that the levels of transforming growth factor $\beta 1$, a chondrogenic and osteogenic promoting factor, could be modulated in response to regulatory factors like $17 \beta$-estradiol and vitamin D3 by varying the micro roughness of titanium surfaces.

Nanoscale topographical cues have also been used to investigate the influence of biomaterial surface properties on cell osteogenic differentiation. Dalby et al. [19] used electron beam lithography to write different nanoscale patterns on a silicon substrate. Nickel dies were made from the patterned resists and used to transfer patterns on to a poly methyl methacrylate (PMMA) substrate by hot embossing. In their study, human mesenchymal stromal cells (hMSCs) were cultured on surfaces containing nanoscale patterns that varied in arrangement 
(square, hexagonal) or disorder (disordered square arrays or random arrays). Disordered square arrays were found to stimulate hMSCs to express osteogenic markers and produce bone mineral in amounts comparable to the use of osteogenic culture medium supplements. In other studies, self assembly of silica nanoparticles was used to modulate surface roughness [20-21] on various substrates like stainless steel, titanium, glass and poly(lactic acid) (PLA). Substrate roughness was shown to increase with increasing nanoparticle diameter $(50-100 \mathrm{~nm})$ [20]. Increased DNA amounts and enhanced osteogenic differentiation as assessed by mRNA expression of bone sialoprotein were observed in hMSCs cultured on nanoparticle modified surfaces compared to unmodified surfaces. These studies present various possibilities to influence cell fate by modulating the surface properties of two-dimensional (2D) substrates used for culture. Plasma treatment is a simple process to modify the physical and chemical characteristics of biomaterials without altering their bulk properties [22]. It can be performed using different gases likeargon [23-25],oxygen [26-28] , methane [29] and ammonia [30]. Scaffolds prepared from various natural[23, 25, 29] (e.g. chitosan, silk fibroin) and synthetic polymers [31-34] (e.g. polylactide-co-glycolide, poly-epsilon-caprolactone and polylactic acid) in different forms like films [26], electrospun meshes [31-32, 34] and rapid prototyped 3D scaffolds [33] have so far been plasma treated to modify the physical and chemical characteristics and to enhance biological activity.

While studies on substrate modification using plasma treatment are generally thorough in terms of material characterisation, most of them fall short in evaluating biological activity. Several investigations focused on basic biological parameters like cell attachment and proliferation.[22-23, 29, 32] More recently, ammonia plasma treatment was used on PLA scaffolds to form amide groups. The presence of amide groups enhanced the osteogenic differentiation of rat bone marrow stromal cells cultured on the treated scaffolds [30].

In this study, we applied oxygen plasma treatment to electrospun PolyActive $^{\text {TM }}$ (PA) fibrous scaffolds to modulate surface roughness and chemical properties and evaluate osteogenic differentiation of hMSCs on the resulting three-dimensional meshes. PA is a family of block copolymers of poly (ethylene oxide terephthalate) and poly (butylene 
terephthalate) (PEOT/PBT). PA has been used in tissue engineering applications involving bone [35] and cartilage [36]. PA or composites containing PA have been processed into scaffolds by several methods like salt leaching [37], rapid prototyping [36] and electrospinning $[7,15]$. In previous studies, compression moulded or solvent cast PA films of a different PEOT/PBT composition were treated with carbon dioxide $\left(\mathrm{CO}_{2}\right)$ plasma treatment [38] and showed increased attachment and growth of rat bone marrow stromal cells [38]. To the best of our knowledge, limited studies have been performed on the modulation of roughness with plasma treatment and the effect of the resulting $3 \mathrm{D}$ surface-textured scaffolds on the osteogenic differentiation of hMSCs. The variation of roughness with treatment time was characterised using different microscopy and surface energy analyses, while the osteogenic differentiation of hMSCs was evaluated as a function of alkaline phosphatase (ALP) production and of osteogenic gene expression.

\section{MATERIALS AND METHODS}

DolyActive ${ }^{\mathrm{TM}}$ (PA) was provided by PolyVation BV, The Netherlands. Following an aPEOTbPBTc nomenclature, the composition used in this study was 300PEOT55PBT45 where, (a) is the molecular weight in $\mathrm{g} / \mathrm{mol}$ of the starting poly(ethylene glycol) (PEG) blocks used in the copolymerisation, while (b) and (c) are the weight ratios of the PEOT and PBT blocks, respectively.

\section{FABRICATION AND SURFACE TREATMENT OF SCAFFOLDS}

A $28 \%(\mathrm{w} / \mathrm{v})$ solution of PA was prepared in a mixture of chloroform $\left(\mathrm{CHCl}_{3}\right)$-1, 1, 1, 3, 3, 3- hexafluoro-2-propanol (HFIP) $(78-22 \% \mathrm{v} / \mathrm{v})$ and stirred overnight at room temperature before use. The solution was loaded into a syringe and the flow rate was controlled using a syringe pump (KDS 100, KD Scientific). The other end of the syringe was connected to a needle via tubing, on which a positive high voltage was applied using a high voltage generator (Gamma High Voltage Research Inc., USA). A metallic sheet of stainless steel was the collector (ground). An electrostatic field was formed between the needle and the collector when the generator was turned on. The polymer solution was pushed through the syringe to the tip of the needle. When the electro- 
static field strength overcame the surface tension of the liquid drop at the tip of the needle, the drop was stretched into fibres and deposited onto the collector. A constant voltage of $12 \mathrm{kV}$ was applied while the distance and flow rate were fixed at $15 \mathrm{~cm}$ and $15 \mathrm{~mL} / \mathrm{hr}$. Temperature during spinning was around $20{ }^{\circ} \mathrm{C}$ and humidity varied between $30 \%$ and $50 \%$.

Electrospun fibre mats were treated with oxygen plasma using a SPI Plasma-Perp II (Structure Probe, Inc., West Chester, USA). A radiofrequency of $13.56 \mathrm{MHz}$, power of $100 \mathrm{~W}$, pressure around $200 \mu \mathrm{m}$ ( 0.267 bar) was used. The chamber was first cleaned to remove any impurities by performing a cycle without samples for 20 minutes. Two electrospun fibre mats measuring $3 \mathrm{~cm} \times 3 \mathrm{~cm}(\sim 200 \mu \mathrm{m}$ thick $)$ each were placed in the chamber and plasma treatment was performed for the required amount of time.

CHARACTERISATION OF SCAFFOLDS - MORPHOLOGY, SURFACE ROUGHNESS AND CHEMICAL CHARACTERISATION

The morphology of electrospun fibres before and after plasma treatment was observed using Scanning Electron Microscopy (SEM) in secondary electron mode (XL 30 ESEM-FEG, Philips). Fibre diameters were calculated from SEM micrographs by measuring 45 fibres per condition using Image J. Contact angle on treated and untreated electrospun scaffolds was measured using a Dataphysics OCA 20 contact angle system.

Measurement of surface roughness was carried out using atomic force microscopy (AFM). All the samples were fixed with double-sided tape to magnetic stubs. The images were obtained at ambient conditions using tapping mode, with a cantilever stiffness of about $50 \mathrm{~N} / \mathrm{m}$ (TESP tip, Bruker), a scan area of $2 \times 2 \mu \mathrm{m}$ and a resolution of $256 \times 256$ pixels. A total of 14 images were analysed per condition and the roughness presented as the arithmetic mean value $\mathrm{Ra}$, expressed as mean \pm standard deviation of these measurements. A plane fit was applied to the image and surface roughness was calculated in Nanoscope V6. 3-D images were generated using SPIPTM software (Image metrology A/S, Denmark).

XPS was performed to determine the chemical composition of the 
treated and untreated surfaces and to calculate any change in chemical composition due to the treatment. The analysis was carried out on a Quantera SXM (scanning XPS microprobe) from Physical Electronics. The measurements were performed with monochromatic Al-K $\alpha$ radiation at $1486.6 \mathrm{eV}$. The main peak of $\mathrm{C} 1 \mathrm{~s}$ peak was set at $284.8 \mathrm{eV}$ and Multipak v.9.0.0 was used for data reduction.

PROTEIN ADSORPTION ON SCAFFOLDS USING BICINCHONINIC ACID (BCA) PROTEIN ASSAY

Bovine serum albumin (BSA) was used as a model protein to evaluate the protein adsorption on the electrospun and surface treated scaffolds. Tissue culture plates were used as controls. $6 \mathrm{~mm}$ discs of different samples ( $\mathrm{n}=3$ for each group) were punched and placed in a 96 well plate. The scaffolds were incubated in phosphate buffered saline (PBS) solution at $37^{\circ} \mathrm{C}$ overnight before protein adsorption to pre-wet them. PBS was removed and $200 \mu 1$ of BSA solution $(2 \mathrm{mg} / \mathrm{mL})$ was added to the wells and the samples were incubated at $37{ }^{\circ} \mathrm{C}$ overnight. The samples were washed with PBS to remove any non-adherent proteins and then transferred to new wells to ensure that proteins attached to the walls and to the bottom of the plate were not measured. The amount of protein present was quantified using a Bicinchoninic acid (BCA) protein assay kit as per manufacturer's (Thermo Scientific Pierce BCA Protein Assay Kit) protocol. The analysis was performed using a TECAN Safire2 plate reader and measured at $562 \mathrm{~nm}$.

\section{HUMAN MESENCHYMAL STROMAL CELL (HMSC) ISOLATION AND IN VITRO CELL CULTURE}

Bone marrow aspirates were obtained from patients after written informed consent, and hMSCs were isolated and proliferated as described previously [39]. Briefly, aspirates were re-suspended by using 20 -gauge needles, plated at a density of $5 \times 10^{5} \mathrm{cells} / \mathrm{cm}^{2}$ and cultured in hMSC proliferation medium containing $\alpha$-minimal essential medium (Life Technologies), 10\% foetal bovine serum (Cambrex), 0.2 $\mathrm{mM}$ ascorbic acid (Asap; Life Technologies), $2 \mathrm{mM}$ L-glutamine (Life Technologies), 100 units/mL penicillin (Life Technologies), $10 \mu \mathrm{g} / \mathrm{mL}$ streptomycin (Life Technologies), and $1 \mathrm{ng} / \mathrm{mL}$ basic fibroblast growth 
factor (FGF) (Instruchemie). Cells were grown at $37^{\circ} \mathrm{C}$ in a humid atmosphere with $5 \% \mathrm{CO}_{2}$. Medium was refreshed twice a week, and cells were used for further sub-culturing or cryopreservation. Cells were trypsinised prior to seeding on scaffolds.

The in vitro experiments were performed with cells from a single donor at passages 3-4. Electrospun discs with a diameter of $15 \mathrm{~mm}$ (thickness $\sim 100 \mu \mathrm{m}$ ) were soaked in $100 \%$ ethanol for 30 minutes and dried in a laminar flow cabinet. The scaffolds were washed twice with sterile PBS, transferred to a non-treated 24 well plate (NUNC) and incubated at $37^{\circ} \mathrm{C}$ in a humid atmosphere with $5 \% \mathrm{CO}_{2}$ for four hours in basic cell culture medium. Rubber O-rings (from Eriks BV, The Netherlands) were used to secure the discs in place and to prevent them from floating. After removing the medium, each scaffold was seeded with 50,000 cells in $200 \mu \mathrm{L}$ basic medium. The cell-scaffold constructs were incubated for three hours to allow cell attachment and topped up to $2 \mathrm{~mL}$ with basic or osteogenic medium. The hMSC basic medium was composed of hMSC proliferation medium without basic FGF and hMSC osteogenic medium was composed of hMSC basic medium supplemented with $10^{-8} \mathrm{M}$ dexamethasone (Sigma). Medium was refreshed after each Alamar Blue measurement.

\section{CEll METABOlism AND AMOUNT OF DNA}

Alamar blue assay was used to assess the cell metabolism. Culture medium was replaced with medium containing $10 \%(\mathrm{v} / \mathrm{v})$ Alamar blue solution (Biosource, Camarillo, CA, USA) and the cells were incubated at $37^{\circ} \mathrm{C}$ for 4 hours. Fluorescence was measured at $590 \mathrm{~nm}$ on a Perkin Elmer Victor ${ }^{3} 1420$ Multilabel plate reader. Cell metabolism was analysed on day 1, 4 and 7 and the readout from the scaffolds $(\mathrm{n}=$ 6) was corrected with the blank from each group.

DNA assay was performed on day 7. Cell numbers were determined using the CyQUANT ${ }^{\circledR}$ DNA quantification kit (Invitrogen) with $50 \mu \mathrm{L}$ of cell lysate according to the manufacturer's protocol. Fluorescence was measured at an excitation wavelength of $480 \mathrm{~nm}$ and an emission wavelength of $520 \mathrm{~nm}$ using a Perkin Elmer LS50B plate reader. 
ALKALINE PHOSPHATASE (ALP) ASSAY

ALP activity was assessed biochemically on day 7. $40 \mu \mathrm{L}$ of CDPstar $^{\mathrm{TM}}$ reagent (Roche) was added to a $10 \mu \mathrm{L}$ aliquot of cell lysate and incubated for 30 minutes in the dark at $25^{\circ} \mathrm{C}$. Chemo luminescence was measured in a Perkin Elmer Victor3 1420 Multilabel plate reader and the amount of ALP per scaffold was normalised using DNA amounts.

\section{CELL ATTACHMENT AND MORPHOLOGY BY FLUORESCENT STAINING AND SEM}

On day 7, medium was removed and the scaffolds were washed twice with PBS and fixed in 10\% formalin for one hour. After rinsing with PBS, the scaffolds were dehydrated in a series of increasing ethanol concentrations $(70 \%, 80 \%, 90 \%, 96 \%, 100 \% \times 2), 15$ minutes in each concentration, before being dried in a critical point dryer (Balzers CPD-030). The samples were then sputter coated with gold (Cressington) for observation on the SEM (Quanta 600F ESEM).

Samples for phalloidin staining were fixed in paraformaldehyde solution $(4 \% \mathrm{w} / \mathrm{v})$ for 10 minutes and rinsed with PBS to examine the cytoskeleton. The cell membrane was permeabilised by treating the sample with $0.01 \%$ Triton $\mathrm{X}-100$ for 5 minutes at room temperature and then washed with PBS $(2 x)$. The samples were incubated for 20 minutes at room temperature with a methanolic phalloidin stock solution (Invitrogen, Alexa Fluor 488 Phalloidin, Excitation/Emission: 495/518 nm, dilution 1:100 in PBS). The samples were then washed with PBS (2x) and counterstained with a $300 \mathrm{nM}$ DAPI solution for 10 minutes to stain the nucleus.

\section{RNA ISOLATION AND GENE EXPRESSION ANALYSIS USING QUANTITATIVE PCR}

To analyse the expression of osteogenic markers by hMSCs, total RNA was isolated using a combination of the TRIzol ${ }^{\circledR}$ method with the NucleoSpin ${ }^{\circledR}$ RNA II isolation kit (Bioké). Briefly, scaffolds were washed with PBS once and $1 \mathrm{~mL}$ of TRIzol reagent (Invitrogen) was added to the samples. After five minutes, the samples were stored at $-80{ }^{\circ} \mathrm{C}$ for RNA isolation. Two samples from each scaffold type were combined to 
ensure sufficient quantity of RNA ( $\mathrm{n}=3$ for analysis). After chloroform addition and phase separation by centrifugation, the aqueous phase containing the RNA was collected, mixed with equal volume of $75 \%$ ethanol and loaded onto the RNA binding column of the kit. Subsequent steps were in accordance with the manufacturer's protocol. RNA was collected in RNAse-free water. The quality and quantity of RNA was analysed by gel electrophoresis and spectrophotometry. One $\mu \mathrm{g}$ of RNA was used for first strand cDNA synthesis using iScript (Bio-Rad) according to the manufacturer's protocol. One microlitre of undiluted cDNA was used for subsequent analysis. PCR was performed on an iQ5 real time PCR machine (Bio rad) using SYBR Green supermix (Bio rad). Expression of osteogenic marker genes was normalised to GAPDH (5'- CGCTCTCTGCTCCTCCTGTT- 3' and 5'-CCATGGTGTCTGAGCGATGT -3')) levels and fold inductions were calculated using the comparative $\Delta \mathrm{CT}$ method [40].

The following primer sequences were used for the osteogenic marker genes: Osteocalcin (OC) (5'-GGCAGCGAGGTAGTGAAGAG-3' and 5'-GATGTGGTCAGCCAACTCGT-3'), Bone Sialoprotein (BSP) (5'-TGCCTTGAGCCTGCTTCC-3' and 5'-CAAAATTAAAGCAGTCTTCATTTTG-3'), Collagen type 1 (5'-GTCACCCACCGACCAAGAAACC-3' and 5'-AAGTCCAGGCTGTCCAGGGATG-3'), Osteopontin (OP) (5'-CCAAGTAAGTCCAACGAAAG-3 and 5'-GGTGATGTCCTCGTCTGTA-3'), Osteonectin (ON) (5'-ACTGGCTCAAGAACGTCCTG-3' and 5'-GAGAGAATCCGGTACTGTGG-3'), and Alkaline Phosphatase (ALP) (5'-GACCCTTGACCCCCACAAT-3' and 5'-GCTCGTACTGCATGTCCCCT-3').

\section{STATISTICAL ANALYSIS}

One way ANOVA with Tukey's multiple comparison post-hoc test was performed. The level of significance was set at 0.05. All data presented are expressed as mean \pm standard deviation. 


\section{RESULTS}

FABRICATION, SURFACE TREATMENT AND CHARACTERISATION OF ELECTROSPUN SCAFFOLDS

D A fibres were successfully electrospun into a non-woven mesh with 1 a fibre diameter of $5.49 \pm 0.96 \mu \mathrm{m}$. SEM images clearly indicate the difference between untreated fibres (Figure 1B) and plasma treated surfaces. Figure 1 (A, B) shows the electrospun PA mesh in different

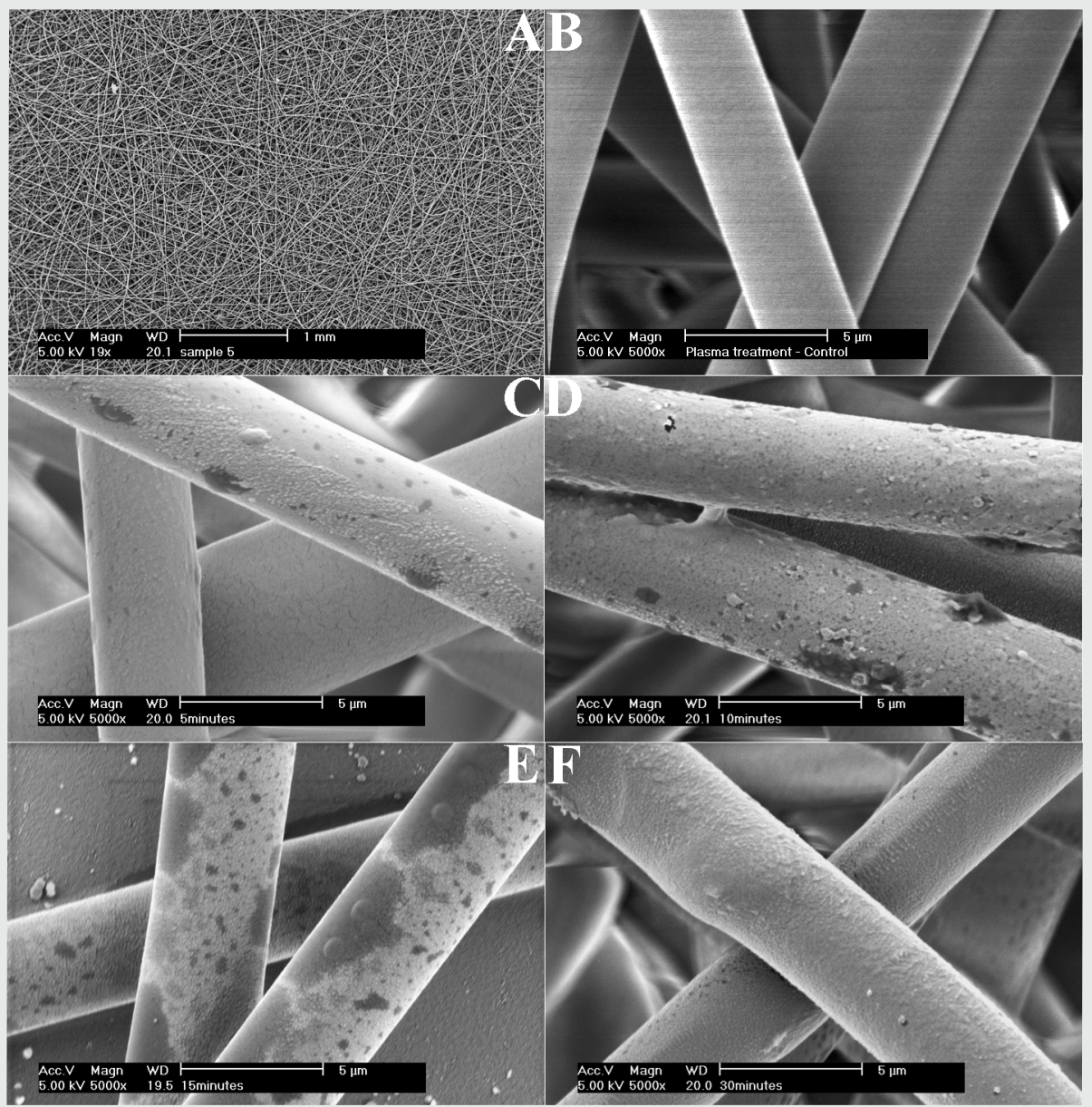

Figure 1: Scaffold morphology using SEM. (A) Electrospun scaffolds under low magnifcation (scale bar 1mm). (B-F) Untreated scaffold, scaffold plasma treated for 5, 10, 15 and 30 minutes respectively (scale bar $5 \mu \mathrm{m}$ ) 
magnifications. After $5 \mathrm{~min}$ of plasma treatment, rough features resembling granules began to appear on the fibre surface, although they
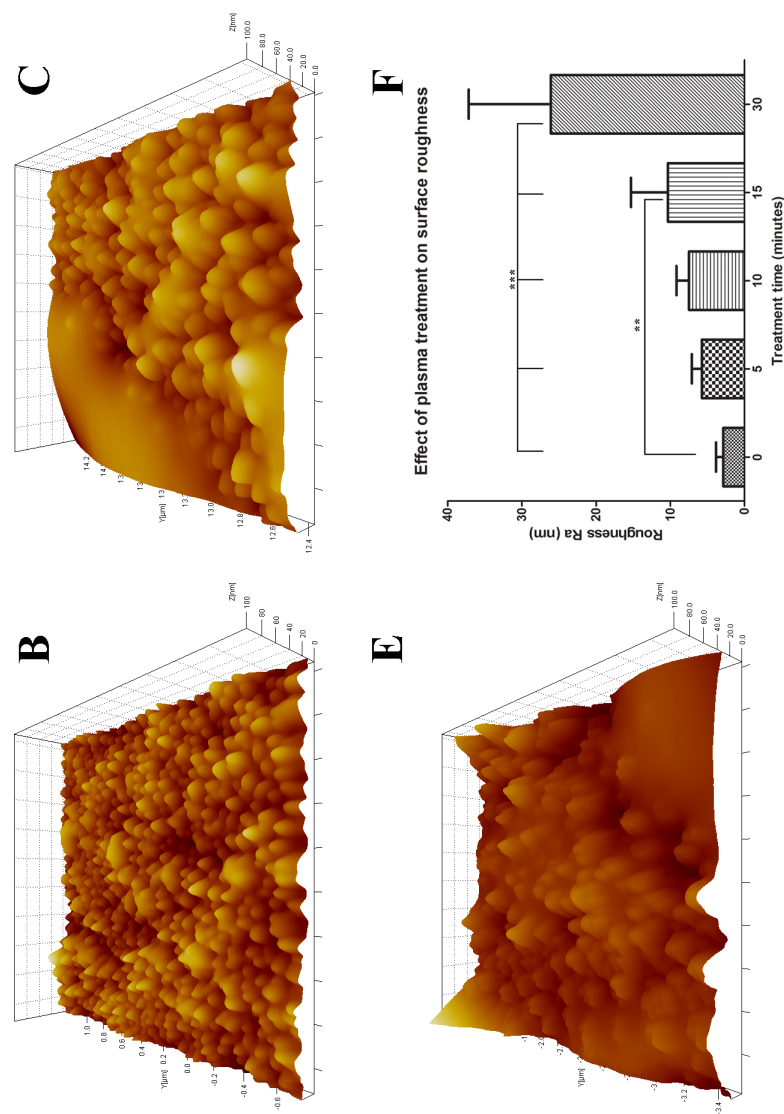

[I]
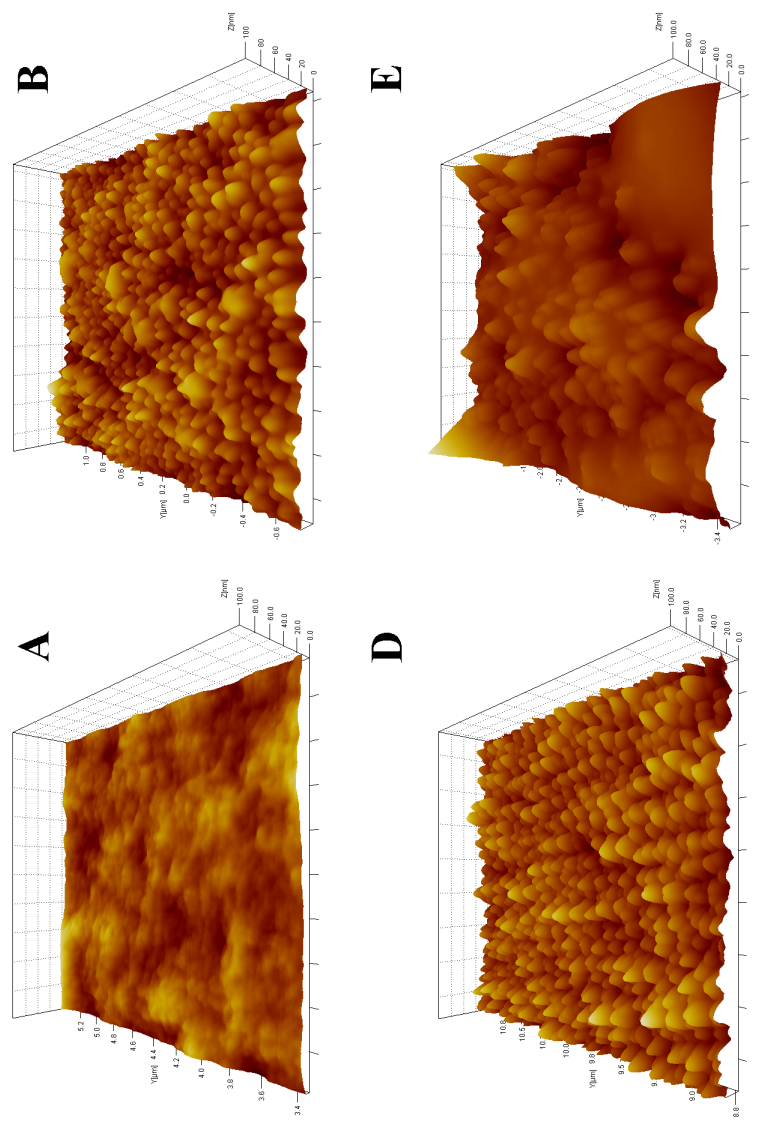

Figure 2: Characterisation of surface roughness using AFM. Three dimensional depiction of surface topography of different scaffolds (A) untreated, (B) $5 \mathrm{~min}$, (C) $10 \min (D) 15$ min and (E) 30 min. F-Quantification of surface roughness of electrospun scaffolds. Data is presented as mean \pm standard deviation. $n=14$. ** represents $p<0.01$ and *** represents $p<0.001$ 
were not observed in all regions of the fibre (Figure $1 \mathrm{C}$ ). Treatment of 10 minutes and longer resulted in larger rough areas of the fibres.
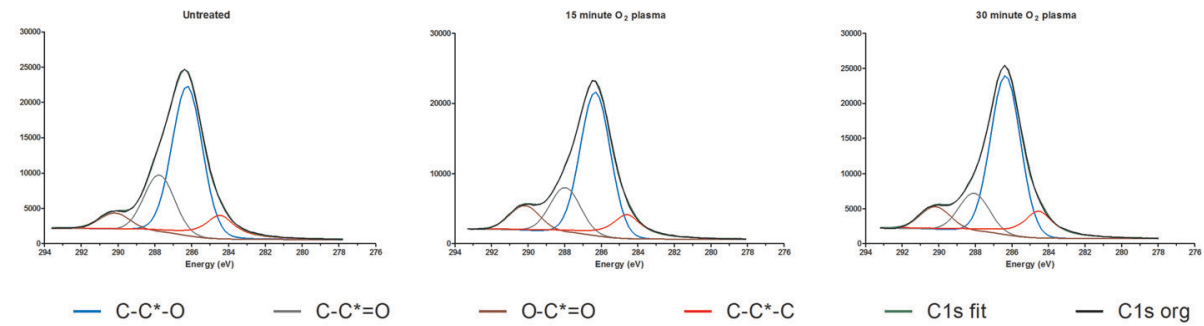

$-\mathrm{O}-\mathrm{C}^{*}=\mathrm{O}$

$-C^{-}-C^{*}-\mathrm{C}$

$-\mathrm{C} 1 \mathrm{~s}$ fit $\quad-\mathrm{C} 1 \mathrm{~s}$ org

Figure 3: Scaffold characterisation using XPS. C1s peaks of untreated, 15-minute O2 and 30 -minute O2 plasma treated electrospun scaffolds

\begin{tabular}{|l|l|l|l|l|l|l|}
\hline Scaffold & $\mathrm{C}$ & $\mathrm{O}$ & $\mathrm{N}$ & $\mathrm{Na}$ & $\mathrm{Si}$ & $\mathrm{O} / \mathrm{C}$ \\
\hline Untreated & 78.76 & 20.42 & 0.45 & 0.14 & 0.24 & 0.259 \\
\hline $\begin{array}{l}15 \mathrm{~min} \\
\text { plasma }\end{array}$ & 75.68 & 23.00 & 0.54 & 0.33 & 0.45 & 0.304 \\
\hline $\begin{array}{l}30 \mathrm{~min} \\
\text { plasma }\end{array}$ & 75.68 & 22.56 & 0.94 & 0.20 & 0.63 & 0.299 \\
\hline
\end{tabular}

Table 1a: Elemental composition of scaffolds by XPS

\begin{tabular}{|l|l|l|l|l|}
\hline Scaffold & $\begin{array}{l}\mathrm{C}-\mathrm{C}^{*}-\mathrm{C} \\
(284.8 \mathrm{eV})\end{array}$ & $\begin{array}{l}\mathrm{C}-\mathrm{C}^{*}-\mathrm{O} \\
(286.4 \mathrm{eV})\end{array}$ & $\begin{array}{l}\mathrm{C}-\mathrm{C}^{*}=\mathrm{O} \\
(287.9 \mathrm{eV})\end{array}$ & $\begin{array}{l}\mathrm{O}-\mathrm{C}^{*}=\mathrm{O} \\
(290.4 \mathrm{eV})\end{array}$ \\
\hline Untreated & 9.0 & 62.6 & 22.2 & 6.2 \\
\hline $\begin{array}{l}15 \mathrm{~min} \\
\text { plasma }\end{array}$ & 8.6 & 65.4 & 16.6 & 9.5 \\
\hline $\begin{array}{l}30 \mathrm{~min} \\
\text { plasma }\end{array}$ & 11.3 & 64.4 & 15.5 & 8.8 \\
\hline
\end{tabular}

Table $1 b$ - Fractions of various functional groups from C1s peaks

The change in surface roughness due to plasma treatment was quanti- 
fied using AFM. Figure 2 A-E shows three dimensional representations of surface topography for different treatment times, illustrating the differences in the roughness between the untreated and treated fibres. Surface roughness was observed to increase exponentially with treatment time $\left(\mathrm{y}=3.4904 \mathrm{e} 0.0694 \mathrm{x}, \mathrm{R}^{2}=0.971\right)$ (Figure $\left.2 \mathrm{~F}\right)$. Fibres treated for 15 minutes in oxygen plasma had a significantly higher $(\mathrm{p}<0.01)$ surface roughness compared to untreated fibres, while the surface roughness of fibres treated for 30 minutes was significant increased $(p<0.001)$ compared to all other treatment times and untreated fibres. A water contact angle of $117^{\circ}$ was observed for untreated fibres. The increased hydrophilicity of the scaffolds due to oxygen plasma treatment was confirmed when the water droplet quickly spread on the fibre mesh resulting in very low contact angles that could not be measured with water.

XPS measurements were performed on untreated meshes and scaffolds treated for 15 and 30 minutes respectively (Figure 3). The elemental composition and the $\mathrm{O} / \mathrm{C}$ ratio of the different treated samples are presented in table $1 \mathrm{a}$. It can be noted that the $\mathrm{O} / \mathrm{C}$ ratio increased after oxygen plasma treatment. Some impurities - nitrogen, sodium and silicon were observed in all treated samples and this could be due to sample storage and handling during processing and plasma treatment. The distribution of various functional groups in different scaffolds is shown in table $1 \mathrm{~b}$. Plasma treatment generally led to an increase in the percentage of $\mathrm{C}-\mathrm{C}^{*}-\mathrm{O}$ and $\mathrm{O}-\mathrm{C}^{*}=\mathrm{O}$ bonds and a decrease in $\mathrm{C}-\mathrm{C}^{*}=\mathrm{O}$ bonds.

\section{EFFECT OF PLASMA TREATMENT ON PROTEIN ADSORPTION}

Protein adsorption on the different scaffolds was studied using BSA as a model protein and tissue culture plastic plates were used as control. The results of the BCA assay are shown in figure 4. The amount of adsorbed protein on tissue culture plastic was significantly lower when compared to untreated, 10,15 and 30-minute plasma treated samples. Among the electrospun scaffolds, fibres treated for 15 and 30 minutes showed significantly higher protein adsorption compared to untreated fibres and scaffolds treated for 5 and 10 minutes, respectively. 


\section{Protein adsorption on different surfaces}

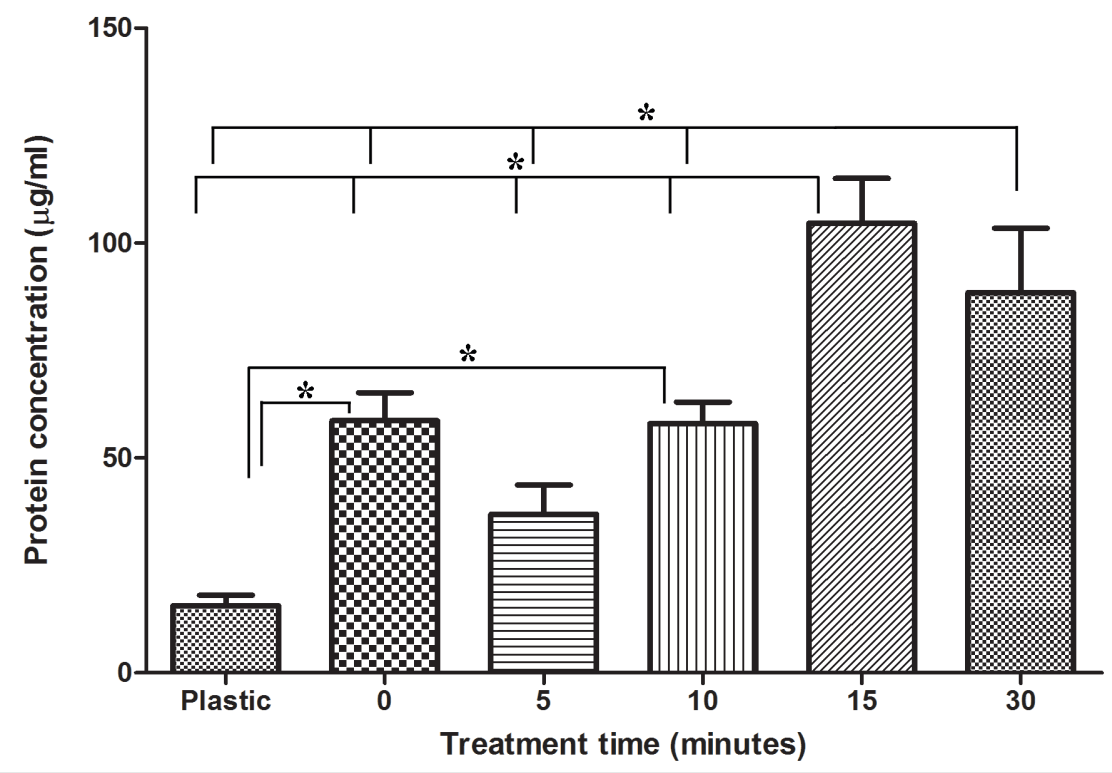

Figure 4: Adsorption of Bovine Serum Albumin (BSA) on different surfaces. Tissue culture plastic was used as a control. Data is presented as mean \pm standard deviation. $n=3$. * represents $p<0.05$

\section{METABOLIC ACTIVITY, DNA AMOUNTS AND ALP EXPRESSION OF HMSCS}

Metabolic activity of cells seeded on different surface treated scaffolds was assessed using Alamar blue assay (days 1, 4 and 7) and the results are presented in figure $5 \mathrm{~A}$. No statistically significant differences due to surface treatment were observed in either basic or osteogenic medium. Cells cultured in all the scaffolds showed a significant increase in metabolic activity of hMSCs from day 1 to 4 , with the exception of 30-minute treated scaffolds in osteogenic medium. The metabolic activity of all the groups was highest on day 4 . At day 7 , a decrease in metabolic activity occurred compared to day 4 , though only significant for 30-minute plasma treated scaffolds in basic culture medium. Metabolic activity of cells at day 7 was significantly higher compared to day 1 for untreated scaffolds in basic and osteogenic medium and for 15-minute treated scaffolds in osteogenic medium. 
Amount of DNA present in the scaffolds after seven days was measured

A
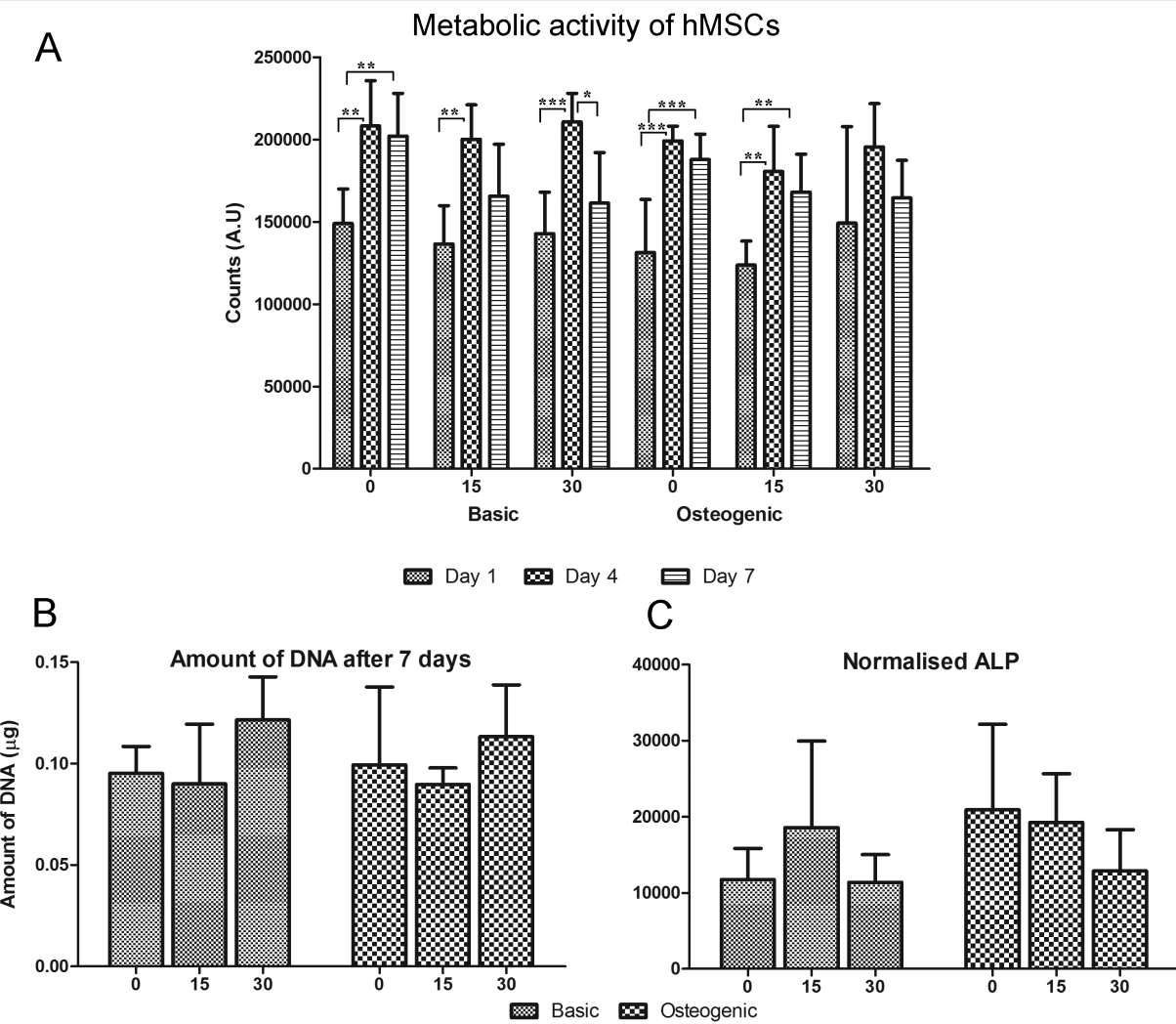

Figure 5: In vitro cell culture analysis. (A) Metabolic activity, (B) DNA amounts and (C) Normalised ALP amounts of cells cultured on different scaffolds. Data is shown for $n=6$ samples for Alamar blue and $n=3$ for DNA and ALP amounts and expressed as mean \pm standard deviation. ${ }^{*}$ represents $p<0.05,{ }^{* *}$ represents $p<0.01$ and $* * *$ represents $p<0.001$

and displayed in figure 5B. No significant differences in DNA amounts were observed between the different groups. Alkaline phosphatase activity was measured using a biochemical assay and normalised with cell amounts (Figure 5C). No significant differences in normalised ALP expression were observed due to medium or type of scaffold used. 


\section{CELl ATTACHMENT, SPREADING AND MORPHOLOGY}

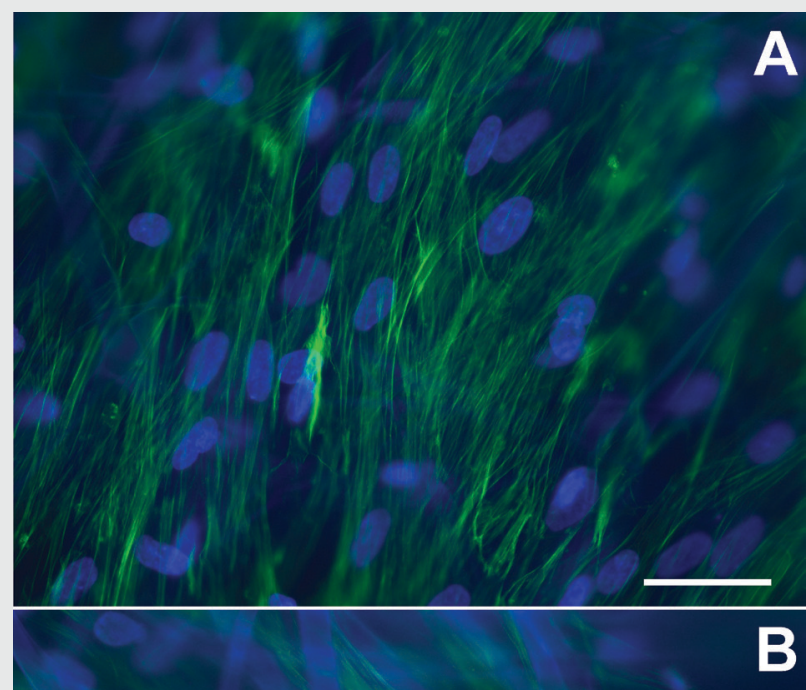

Figure 6: Cytoskeleton arrangement after seven days on (A) untreated (B) 15 minute plasma treated and $(C) 30$ minute plasma treated scaffolds in osteogenic medium. Green represents the actin filaments from cytoskeleton stained by phalloidin and nuclei are stained blue by DAPI. The electrospun fibres appear blue due to autoflourescence. Scale bar $50 \mu \mathrm{m}$ 


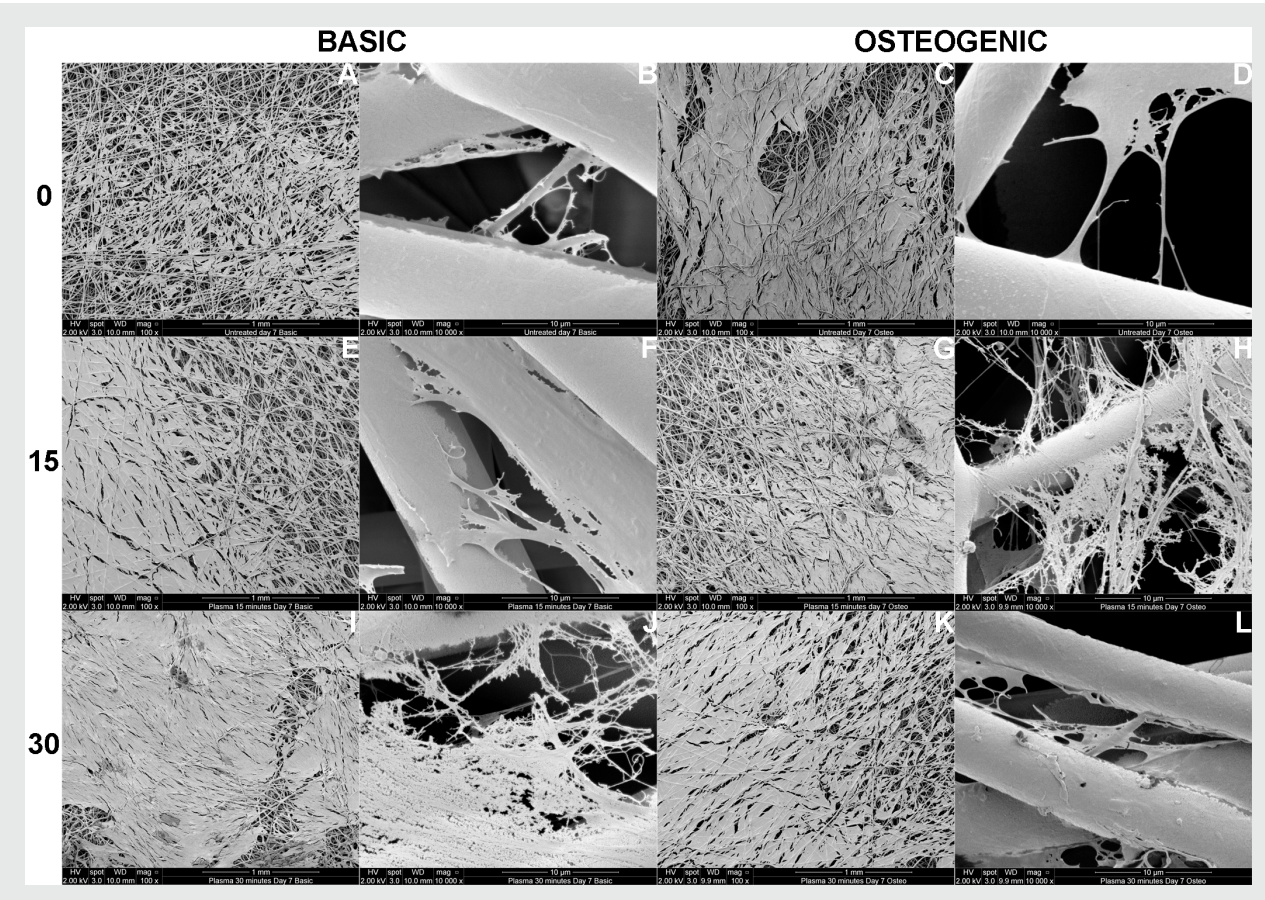

Figure 7: Cell morphology on various scaffolds on day 7 using SEM. Different scaffolds are shown in rows and different magnifications in basic and osteogenic media is shown in columns. Untreated, 15 min and 30 min treated scaffolds in basic medium are represented by images. Scale bar for A, C,E, G,I and $K$ is $1 \mathrm{~mm}$ and for B,D,F,H,J and $L$ is $10 \mu \mathrm{m}$

Attachment of hMSCs on various scaffolds was visualised using nucleus and cytoskeleton fluorescent staining and SEM analysis. All scaffolds provided suitable surfaces for hMSCs to attach (Figure 6). Arrangement of actin filaments in the images indicates a stretched and spread morphology of the cells on the scaffolds.

Figure 7 shows SEM micrographs of hMSCs on various scaffolds on day 7. An overview of cell spreading on scaffolds can be observed at lower magnification (Figures 7A, 7C, 7E, 7G, 7I and 7K). Electrospun surfaces are known to provide favourable surfaces for cell attachment and proliferation, which is confirmed from the SEM micrographs. Cells cultured on plasma treated samples covered almost the entire surface of the electrospun mesh after 7 days of culture (Figures 7E, 7G, 7I and $7 \mathrm{~K})$. Conversely, untreated samples showed less cell coverage indicating a slightly slower proliferation (Figures 7A, 7C). Qualitatively, these images concur with the trend observed for the DNA assay. Increased extracellular matrix production with fibrillar morphology can 
also be observed in plasma treated samples (Figures $7 \mathrm{~J}, 7 \mathrm{H}$ ).

GENE EXPRESSION ANALYSIS OF OSTEOGENIC MARKERS USING QUANTITATIVE PCR

The expression of osteogenic markers BSP, ON, OC, OP, Col-I and ALP in cells cultured on untreated, 15 and 30 min plasma treated scaffolds in basic and osteogenic medium was assessed using quantitative

\section{Gene expression of osteogenic markers after 7 days}
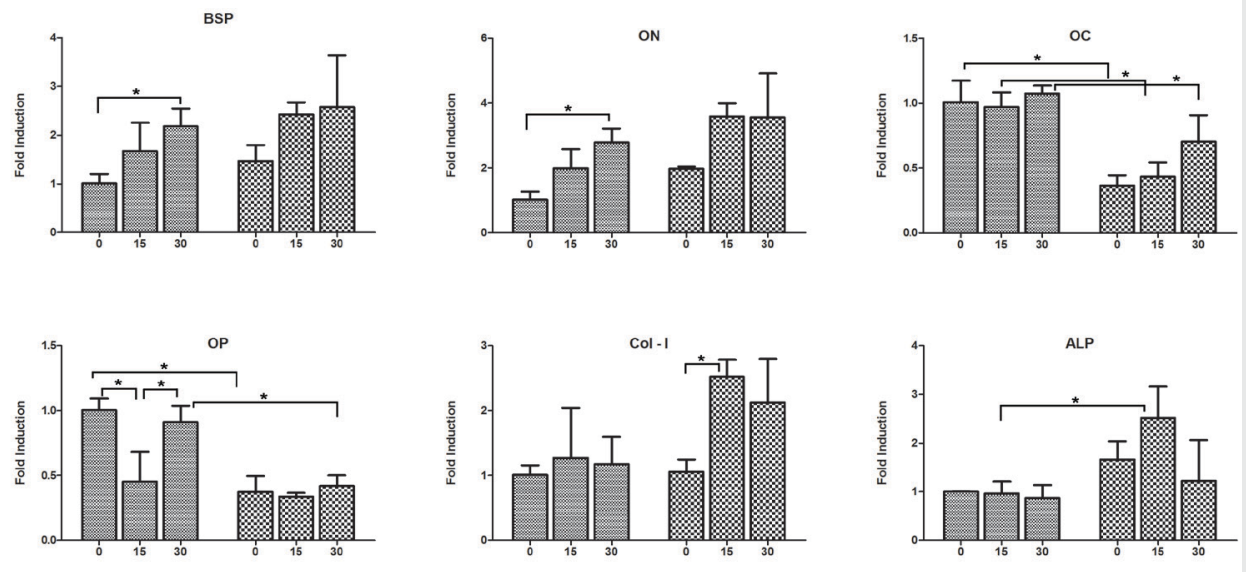

Figure 8: Quantitative PCR analysis for osteogenic markers after 7 days of hMSC culture in untreated, 15 and 30-min oxygen plasma treated scaffolds. * represents $p<0.05$. Data expressed as mean \pm standard deviation for $n=3$

PCR after 7 days of in vitro culture and the results are shown in figure 8. Gene expression was normalised against untreated PA scaffolds in basic medium. The gene expression patterns for BSP and ON were very similar. In basic medium, an increase in gene expression was observed with increasing treatment time and a significant upregulation was observed in 30-minute treated scaffolds compared to untreated scaffolds. In osteogenic medium, cells cultured on plasma treated scaffolds had comparable expression which was higher than untreated scaffolds although no significant differences were observed.

OP expression in 15 minute treated scaffolds in basic medium was sig- 
nificantly downregulated compared to untreated and 30-minute treated samples. Cells cultured on untreated and 30 minute treated samples in basic medium also had a significantly higher expression compared to their counterparts in osteogenic medium. Cells cultured on 15-minute plasma treated scaffolds showed a significantly higher expression of collagen type I in osteogenic medium compared to cells cultured on untreated scaffolds.

Plasma treatment did not result in significant differences in the gene expression of OC and ALP in either medium although an effect of culture medium was observed as seen in figure 8 . From these results, it is suggestive that hMSCs cultured on treated scaffolds in basic medium might be in a mid phase of osteogenesis as early to mid-term markers like BSP and $\mathrm{ON}$ are upregulated, whereas late markers like $\mathrm{OC}$ and OP have basal expression levels.

\section{DISCUSSION}

7 lectrospinning is a widely used technique for fabrication of scaf$\triangle$ folds needed for tissue engineering and regenerative medicine. One main advantage of this process is that it is simple while offering numerous possibilities to produce a wide variety of scaffolds. Fibres of different diameters, morphology or alignment can be obtained by altering flow rate [39], concentration [6], solvent mixture [7], humidity [4-5] and by using different collectors [40-41]. These differences in fibre structure and morphology result in different properties and possibly, a different cellular response. Besides the versatility in creating fibres with different properties, electrospinning is extensively used to fabricate scaffolds that mimic the physical nature of fibrillar extracellular matrix, thereby leading to the production of more biomimetic scaffolds. In recent years, the response of cells to various physical cues like topography and roughness has been broadly studied. On polymeric surfaces, roughness has been modulated using different methods ranging from hand grinding [42] and sand blasting using alumina [43] to plasma treatment [44] and self-assembly of nano particles [20]. The cellular response to change in roughness depends on the cell type, source and the biological process evaluated - proliferation or differentiation - although it is clear that roughness can alter cell response. In the present study, plasma treatment using oxygen was chosen to 
alter surface roughness of the electrospun fibres. Oxygen, being a reactive gas, also modifies the surface chemistry of the fibres in addition to the physical changes in fibre morphology.

In the present study, an increase in surface roughness with plasma treatment time as was observed using SEM and confirmed by AFM roughness measurements. A similar trend was observed by Wei et al. [45] when polyamide fibres were treated using oxygen plasma, and by Cui et al. [46] when polypropylene films were treated with air discharge plasma. It should, however, be noted that an increase in plasma exposure time does not necessarily always correlate with increased roughness. Martins et al. [44] observed a decrease in surface roughness of electrospun PCL fibres with increasing time and plasma power when using oxygen and argon. Melting of electrospun fibres due to plasma treatment was proposed as a possible cause, which is plausible considering the low melting temperature of PCL [47]. These studies demonstrated that it is possible to tune surface roughness based on treatment time and gas used to elicit a targeted and specific cell response.

Contact angle measurements confirmed an increase in hydrophilicity of the plasma treated scaffolds, which is in agreement with various studies performed earlier [27, 44-45] and is attributed to the presence of polar oxygen containing groups that arise due to plasma treatment [46]. XPS data showed a relative increase in oxygen content and an increase in $\mathrm{O} / \mathrm{C}$ ratio in the plasma treated samples. Oxygen content increases due to surface oxidation of the fibres while the decrease in carbon content could be attributed to the melting of the fibres during plasma treatment [44]. When silk fibroin scaffolds were treated with oxygen plasma [27], a similar increase in oxygen content was noted leading to creation of new oxidised functional groups. Poly ( $p$ phenylene benzobisoxazole) fibres [26] treated using oxygen plasma for varying times, showed an increase in the $\mathrm{O} / \mathrm{C}$ ratio compared to untreated fibres. The ratio decreased for treatment time higher than 15 minutes, as was also observed for the plasma treated samples in the current study (although not statistically significant). Similar observations in the reduction of $\mathrm{O} / \mathrm{C}$ ratio were also observed as an effect of plasma power beyond $200 \mathrm{~W}$ [48]. Results from our study are also comparable to the above mentioned studies in terms of fraction of functional groups like $\mathrm{O}-\mathrm{C}^{*}=\mathrm{O}$ and $\mathrm{C}-\mathrm{C}^{*}-\mathrm{C}$. It was hypothesised that 
oxygen plasma treatment induced polar groups like $\mathrm{O}-\mathrm{C}^{*}=\mathrm{O}$ at lower power [48] and that these polar groups could be decomposed at higher treatment power or prolonged treatment time. This suggests that an optimum setting in terms of power and time might exist in order to obtain a high fraction of polar groups, above which they would decrease due to decomposition.

As adsorption is a surface phenomenon, the amount of adsorbed protein depends directly on the available surface area. The higher protein adsorption on untreated electrospun surfaces compared to culture plates can be attributed to the higher surface-to-volume ratio of $3 \mathrm{D}$ electrospun fibre meshes compared to 2D surfaces. Protein adsorption is also affected by surface roughness and chemistry. Santos et al. [49], while analysing the effects of protein adsorption on plasma treated starch based PCL scaffolds, suggested that the increase in surface roughness may result in increasing the surface area available for protein attachment. The introduction of reactive hydroxyl and carboxyl groups by plasma treatment alters the surface chemistry and charge, leading to enhanced adhesion possibly due to increase in hydrogen bond forming ability of these groups. Vogler [50] suggested that carboxyl groups play a key role in cell adhesion to substrates. While the above mentioned hypothesis is generally valid, it should be noted that different proteins adsorb differently on the same surfaces. This was demonstrated on plasma treated starch-polycaprolactone scaffolds [49] with fibronectin and vitronectin. While albumin was chosen only as a model protein to elucidate the effects of plasma treatment on adsorption, our results should be further confirmed for proteins more relevant to bone tissue engineering like BMP-2, known to further enhance osteogenic differentiation of cells on scaffolds. XPS data also showed increased oxygen content in plasma treated scaffolds compared to untreated ones, possibly leading to more reactive groups available for protein binding. In this respect, the higher oxygen amount in $15 \mathrm{~min}$ treated scaffolds could explain the higher adsorption of albumin compared to $30 \mathrm{~min}$ treated scaffolds.

No change in cell morphology was observed among the different scaffolds and confirmed by phalloidin staining. SEM analysis showed a higher coverage by cells on the plasma treated scaffolds and further revealed extracellular matrix production by hMSCs. Cell metabolic 
activity in different scaffold groups was similar up to 4 days of culture. Cells seemed to have reached their peak in metabolic activity at day 4 and showed a decrease at day 7 . This was also associated to a comparable amount of cells in all the evaluated scaffolds, as measured by DNA assay on day 7 . As cell metabolic activity can be connected to proliferation, the observed decrease could be attributed to a lower proliferation rate upon reaching confluency. When plasma treated polyethylene disks were seeded with hMSCs [51], hydrophilic and rough surfaces favoured cell adhesion while cell proliferation was highest on surfaces that were moderately wettable. Oxygen plasma treatment of PLLA non-woven meshes [52] resulted in a more hydrophilic fibre surface associated with a decrease in contact angle from $76^{\circ}$ to $58^{\circ}$ and led to a significantly higher amount of adipose derived hMSCs after 48 hours [52]. An even distribution of cells on the plasma treated scaffolds was also observed. In another study, rat calvarial osteoblasts were cultured on polystyrene surfaces with different roughness [42] and cell numbers increased with increasing roughness up to a particular level $(0.8 \mu \mathrm{m})$ and then decreased with further increase in roughness [42]. This might suggest that an optimum roughness exists for enhanced adhesion. In the present study, while changes in roughness, hydrophilicity and surface chemistry were observed, no effect on biological response of cells pertaining to proliferation was measured.

The ability of hMSCs to differentiate into multiple lineages is one of the most important characteristics that encourage their clinical use. The capacity of a scaffold matrix to promote osteogenic differentiation of hMSCs is highly important in the context of bone repair and regeneration of defects that do not heal spontaneously. Therefore, the potential of plasma treated scaffolds to promote osteogenesis was evaluated. While no differences were observed in ALP protein production, gene expression of BSP and ON were upregulated in the plasma treated scaffolds suggesting that these modified surfaces might favour osteogenic differentiation. Most plasma treatment studies focused mainly on evaluating cell adhesion and proliferation. Limited studies analysed gene expression and differentiation of cells. Xu et al. modified PDLLA scaffolds with ammonia plasma treatment and peptide conjugation (GRGDS) to evaluate the osteogenic potential of these scaffolds. An upregulation of osteogenic markers like ALP, OC, OP, Col -I and BMP-2 by rat bone marrow MSCs.at different time points (days 
3, 7 and 14) was observed in both scaffold groups (ammonia treated, ammonia treated + peptide conjugation) Therefore, a combination of plasma treatment and peptide conjugation could enhance in vitro osteogenesis through ammonia plasma treatment and amide group formation [28].

Cells are cognisant of changes in their surrounding environment. Altering the environment to result in favourable biological activity is highly desirable for implantable materials. While addition of components like dexamethasone and ascorbic acid to culture medium promotes osteogenic differentiation of hMSCs, extensive research is currently undertaken to unearth other more effective ways that can promote differentiation of hMSCs in implant materials. The development of several nanotechnologies has increased the possibility and versatility of creating nanoscale structures. While Dalby et al. [19] showed that nanotopographies with a particular pattern led to the osteogenic differentiation of hMSCs comparable to levels observed in the presence of dexamethasone, other researchers have focused on developing a high-throughput screening approach to identify specific topographies that influence ALP expression and mineralisation [53-54]. Such a screening approach combined with iterative design allows for the rapid evaluation and discovery of topographies influencing cell behaviour. While these studies explore limitless possibilities in 2D surfaces or films, the success of regenerating or repairing damaged tissue in vivo depends on translating these results into a $3 \mathrm{D}$ scaffold structure. This underlying rationale was the basis for using plasma treatment to achieve nanoscale topography on a $3 \mathrm{D}$ substrate that structurally mimics the fibrillar nature of the ECM. While plasma treatment has the advantage of not requiring complex and expensive equipment like other nanotechnology methods, it also suffers from the fact that it is difficult to precisely control the properties of the treated scaffolds at high resolution. As plasma treatment causes etching and local melting of polymers, treatment time is a critical factor in order to ensure that the macroscopic fibrous structure of the mesh is preserved. The treatment times used in this study and the obtained roughness could be useful in predicting the outcome of plasma treatment and help tailor different surfaces. The upregulation of some osteogenic markers due to plasma treatment also suggests possible advantages of this method, although these scaffolds have to be evaluated for longer culture periods to assess their mineralisation po- 
tential. As such, this study is a first step towards application of oxygen plasma treated 3D electrospun scaffolds to influence hMSCs osteogenic differentiation for regenerative medicine applications.

\section{CONCLUSIONS}

$\mathrm{T}$ hree dimensional electrospun scaffolds with tunable nanoscale surface roughness were prepared using oxygen plasma treatment. Protein adsorption, cell attachment, proliferation and gene expression were analysed. It was observed that plasma treatment affected the morphology, roughness, hydrophilicity and surface chemistry of the treated fibres. Increased protein adsorption was also observed due to plasma treatment. No differences in proliferation, DNA and normalised ALP amounts were observed. Bone sialoprotein and osteonectin were upregulated in gas plasma treated scaffolds. Therefore, plasma treatment is a simple and easy way to modify electrospun fibres that could possibly improve osteogenic differentiation of human mesenchymal stromal cells.

\section{ACKNOWLEDGEMENTS}

The authors thank Hetty ten Hoopen for technical assistance with 1 atomic force microscopy, Gerard Kip for discussions on the XPS data, Mijke Buitinga for the contact angle measurements. Pamela Habibovic acknowledges financial support by Innovative Research Incentives Scheme Veni of The Netherlands Organisation for Scientific Research.

\section{REFERENCES}

1. Neal RA, McClugage SG, Link MC, Sefcik LS, Ogle RC, Botchwey EA. Laminin Nanofiber Meshes That Mimic Morphological Properties and Bioactivity of Basement Membranes. Tissue Engineering Part C-Methods 2009;15(1):11-21.

2. Doshi J, Reneker DH. Electrospinning Process and Applications of Electrospun Fibers. Journal of Electrostatics 1995;35(2-3):151-160.

3. Dalton PD, Grafahrend D, Klinkhammer K, Klee D, Moller M. Electrospinning of polymer melts: Phenomenological observations. 
Polymer 2007;48(23):6823-6833.

4. Casper CL, Stephens JS, Tassi NG, Chase DB, Rabolt JF. Controlling surface morphology of electrospun polystyrene fibers: Effect of humidity and molecular weight in the electrospinning process. Macromolecules 2004;37(2):573-578.

5. De Vrieze S, Van Camp T, Nelvig A, Hagstrom B, Westbroek P, De Clerck K. The effect of temperature and humidity on electrospinning. J Mater Sci 2009;44(5):1357-1362.

6. Deitzel JM, Kleinmeyer J, Harris D, Tan NCB. The effect of processing variables on the morphology of electrospun nanofibers and textiles. Polymer 2001;42(1):261-272.

7. Moroni L, Licht R, de Boer J, de Wijn JR, van Blitterswijk CA. Fiber diameter and texture of electrospun PEOT/PBT scaffolds influence human mesenchymal stem cell proliferation and morphology, and the release of incorporated compounds. Biomaterials 2006;27(28):49114922 .

8. Laurencin CT, Kumbar SG, Nukavarapu SP, James R, Nair LS. Electrospun poly(lactic acid-co-glycolic acid) scaffolds for skin tissue engineering. Biomaterials 2008;29(30):4100-4107.

9. Yang F, Murugan R, Wang S, Ramakrishna S. Electrospinning of nano/micro scale poly(L-lactic acid) aligned fibers and their potential in neural tissue engineering. Biomaterials 2005;26(15):2603-2610.

10. Li WJ, Danielson KG, Alexander PG, Tuan RS. Biological response of chondrocytes cultured in three-dimensional nanofibrous poly(epsilon-caprolactone) scaffolds. J Biomed Mater Res A 2003;67A(4):1105-1114.

11. Subramanian A, Skotak M, Noriega S, Larsen G. Electrospun cross-linked gelatin fibers with controlled diameter: The effect of matrix stiffness on proliferative and biosynthetic activity of chondrocytes cultured in vitro. J Biomed Mater Res A 2010;95A(3):828-836.

12. Cho M, Wise JK, Yarin AL, Megaridis CM. Chondrogenic Differentiation of Human Mesenchymal Stem Cells on Oriented Nanofibrous Scaffolds: Engineering the Superficial Zone of Articular Cartilage. Tissue Eng Pt A 2009;15(4):913-921. 
13. Li CM, Vepari C, Jin HJ, Kim HJ, Kaplan DL. Electrospun silk-BMP-2 scaffolds for bone tissue engineering. Biomaterials 2006;27(16):3115-3124.

14. Yoshimoto H, Shin YM, Terai H, Vacanti JP. A biodegradable nanofiber scaffold by electrospinning and its potential for bone tissue engineering. Biomaterials 2003;24(12):2077-2082.

15. Nandakumar A, Fernandes H, de Boer J, Moroni L, Habibovic $\mathrm{P}$, van Blitterswijk CA. Fabrication of bioactive composite scaffolds by electrospinning for bone regeneration. Macromol Biosci 2010;10(11):1365-1373.

16. Ranganath $\mathrm{SH}$, Wang $\mathrm{CH}$. Biodegradable microfiber implants delivering paclitaxel for post-surgical chemotherapy against malignant glioma. Biomaterials 2008;29(20):2996-3003.

17. Brett PM, Harle J, Salih V, Mihoc R, Olsen I, Jones FH, et al. Roughness response genes in osteoblasts. Bone 2004;35(1):124-133.

18. Boyan BD, Lossdorfer S, Wang L, Zhao G, Lohmann CH, Cochran DL, et al. Osteoblasts generate an osteogenic microenvironment when grown on surfaces with rough microtopographies. Eur Cell Mater $2003 ; 6: 22-27$.

19. Dalby MJ, Gadegaard N, Tare R, Andar A, Riehle MO, Herzyk $\mathrm{P}$, et al. The control of human mesenchymal cell differentiation using nanoscale symmetry and disorder. Nat Mater 2007;6(12):997-1003.

20. Lipski AM, Jaquiery C, Choi H, Eberli D, Stevens M, Martin I, et al. Nanoscale engineering of biomaterial surfaces. Adv Mater 2007;19(4):553-+.

21. Lipski AM, Pino CJ, Haselton FR, Chen IW, Shastri VP. The effect of silica nanoparticle-modified surfaces on cell morphology, cytoskeletal organization and function. Biomaterials 2008;29(28):38363846 .

22. Park K, Ju YM, Son JS, Ahn KD, Han DK. Surface modification of biodegradable electrospun nanofiber scaffolds and their interaction with fibroblasts. J Biomat Sci-Polym E 2007;18(4):369-382.

23. Wu YC, Lee TM, Lin JC, Shaw SY, Yang CY. Argon-PlasmaTreated Chitosan: Surface Characterization and Initial Attachment of 
Osteoblasts. J Biomat Sci-Polym E 2010;21(5):563-579.

24. Jin SC, Baek HS, Woo YI, Lee MH, Kim JS, Park JC, et al. Beneficial Effects of Microwave-Induced Argon Plasma Treatment on Cellular Behaviors of Articular Chondrocytes Onto Nanofibrous Silk Fibroin Mesh. Macromol Res 2009;17(9):703-708.

25. Hasirci V, Tezcaner A, Hasirci N, Suzer S. Oxygen plasma modification of poly(3-hydroxybutyrate-co-3-hydroxyvalerate) film surfaces for tissue engineering purposes. J Appl Polym Sci 2003;87(8):12851289.

26. Zhang CH, Chen P, Sun BL, Li W, Wang BC, Wang J. Surface analysis of oxygen plasma treated poly(p-phenylene benzobisoxazole) fibers. Appl Surf Sci 2008;254(18):5776-5780.

27. Jeong L, Yeo IS, Kim HN, Yoon YI, Jang DH, Jung SY, et al. Plasma-treated silk fibroin nanofibers for skin regeneration. Int J Biol Macromol 2009;44(3):222-228.

28. Xu ZX, Li T, Zhong ZM, Zha DS, Wu SH, Liu Q, et al. AmideLinkage Formed Between Ammonia Plasma Treated Poly(D,L-lactide acid) Scaffolds and Bio-Peptides: Enhancement of Cell Adhesion and Osteogenic Differentiation In Vitro. Biopolymers 2011;95(10):682694.

29. Chen JP, Su CH. Surface modification of electrospun PLLA nanofibers by plasma treatment and cationized gelatin immobilization for cartilage tissue engineering. Acta Biomater 2011;7(1):234-243.

30. Park SA, Lee SH, Kim W, Han I, Park JC. Effect of Plasma Treatment on Scaffold by Solid Freeform Fabrication. Tissue Eng Regen Med 2011;8(1):A23-A27.

31. Prabhakaran MP, Venugopal J, Chan CK, Ramakrishna S. Surface modified electrospun nanofibrous scaffolds for nerve tissue engineering. Nanotechnology 2008;19(45):- .

32. Park H, Lee KY, Lee SJ, Park KE, Park WH. Plasma-treated poly(lactic-co-glycolic acid) nanofibers for tissue engineering. Macromol Res 2007;15(3):238-243.

33. Mwale F, Wang HT, Nelea V, Luo L, Antoniou J, Wertheimer MR. The effect of glow discharge plasma surface modification of poly- 
mers on the osteogenic differentiation of committed human mesenchymal stem cells. Biomaterials 2006;27(10):2258-2264.

34. Du C, Meijer GJ, van de Valk C, Haan RE, Bezemer JM, Hesseling $\mathrm{SC}$, et al. Bone growth in biomimetic apatite coated porous Polyactive((R)) 1000PEGT70PBT30 implants. Biomaterials 2002;23(23):4649-4656.

35. Woodfield TBF, Malda J, de Wijn J, Peters F, Riesle J, van Blitterswijk CA. Design of porous scaffolds for cartilage tissue engineering using a three-dimensional fiber-deposition technique. Biomaterials 2004;25(18):4149-4161.

36. Claase MB, de Riekerink MB, de Bruijn JD, Grijpma DW, Engbers GHM, Feijen J. Enhanced bone marrow stromal cell adhesion and growth on segmented poly(ether ester)s based on poly(ethylene oxide) and poly(butylene terephthalate). Biomacromolecules 2003;4(1):5763.

37. Both SK, Van der Muijsenberg AJC, Van Blitterswijk CA, De Boer J, De Bruijn JD. A rapid and efficient method for expansion of human mesenchymal stem cells. Tissue Eng 2007;13(1):3-9.

38. Livak KJ, Schmittgen TD. Analysis of relative gene expression data using real-time quantitative PCR and the 2(-Delta Delta C(T)) Method. Methods 2001;25(4):402-408.

39. Moller M, Nottelet B, Pektok E, Mandracchia D, Tille JC, Walpoth $\mathrm{B}$, et al. Factorial design optimization and in vivo feasibility of poly(epsilon-caprolactone)-micro- and narofiber-based small diameter vascular grafts. J Biomed Mater Res A 2009;89A(4):865-875.

40. Natarajan TS, Sundaray B, Subramanian V, Xiang RZ, Chang $\mathrm{CC}$, Fann WS. Electrospinning of continuous aligned polymer fibers. Appl Phys Lett 2004;84(7):1222-1224.

41. Ramakrishna S, Yang F, Murugan R, Wang S. Electrospinning of nano/micro scale poly(L-lactic acid) aligned fibers and their potential in neural tissue engineering. Biomaterials 2005;26(15):2603-2610.

42. Hatano K, Inoue H, Kojo T, Matsunaga T, Tsujisawa T, Uchiyama $\mathrm{C}$, et al. Effect of surface roughness on proliferation and alkaline phosphatase expression of rat calvarial cells cultured on polystyrene. Bone 1999;25(4):439-445. 
43. Lampin M, Warocquier C, Legris C, Degrange M, Sigot-Luizard MF. Correlation between substratum roughness and wettability, cell adhesion, and cell migration. J Biomed Mater Res 1997;36(1):99-108.

44. Martins A, Pinho ED, Faria S, Pashkuleva I, Marques AP, Reis $\mathrm{RL}$, et al. Surface modification of electrospun polycaprolactone nanofiber meshes by plasma treatment to enhance biological performance. Small 2009;5(10):1195-1206.

45. Wei QF, Gao WD, Hou DY, Wang XQ. Surface modification of polymer nanofibres by plasma treatment. Appl Surf Sci 2005;245(14):16-20.

46. Cui NY, Brown NMD. Modification of the surface properties of a polypropylene (PP) film using an air dielectric barrier discharge plasma. Appl Surf Sci 2002;189(1-2):31-38.

47. Sinha VR, Bansal K, Kaushik R, Kumria R, Trehan A. Polyepsilon-caprolactone microspheres and nanospheres: an overview. Int J Pharm 2004;278(1):1-23.

48. Chen P, Zhang CS, Zhang XY, Wang BC, Li W, Lei QQ. Effects of oxygen plasma treatment power on surface properties of poly(pphenylene benzobisoxazole) fibers. Appl Surf Sci 2008;255(5):31533158 .

49. Santos MI, Pashkuleva I, Alves CM, Gomes ME, Fuchs S, Unger RE, et al. Surface-modified 3D starch-based scaffold for improved endothelialization for bone tissue engineering. J Mater Chem 2009;19(24):4091-4101.

50. Vogler EA, Bussian RW. Short-Term Cell-Attachment Rates - a Surface-Sensitive Test of Cell Substrate Compatibility. J Biomed Mater Res 1987;21(10):1197-1211.

51. Kim MS, Shin YN, Cho MH, Kim SH, Kim SK, Cho YH, et al. Adhesion behavior of human bone marrow stromal cells on differentially wettable polymer surfaces. Tissue Eng 2007;13(8):2095-2103.

52. Hanson AD, Wall ME, Pourdeyhimi B, Loboa EG. Effects of oxygen plasma treatment on adipose-derived human mesenchymal stem cell adherence to poly(L-lactic acid) scaffolds. J Biomat Sci-Polym E 2007;18(11):1387-1400. 
53. Unadkat HV, Hulsman M, Cornelissen K, Papenburg BJ, Truckenmuller RK, Post GF, et al. An algorithm-based topographical biomaterials library to instruct cell fate. Proc Natl Acad Sci U S A 2011;108(40):16565-16570.

54. Lovmand J, Justesen E, Foss M, Lauridsen RH, Lovmand M, Modin C, et al. The use of combinatorial topographical libraries for the screening of enhanced osteogenic expression and mineralization. Biomaterials 2009;30(11):2015-2022. 


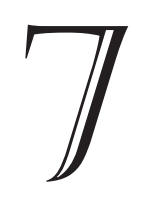

\section{A fast process for imprinting micro- and nanopatterns on electrospun fibre meshes at physiological temperatures}

Anandkumar Nandakumar ${ }^{\mathrm{a}}$, Roman Truckenmüller ${ }^{\mathrm{a}}$, Diogo Reis Santos $^{\mathrm{a}, \mathrm{b}}$, Nils Auffermann ${ }^{\mathrm{a}}$, Pamela Habibovic ${ }^{\mathrm{a}}$, Clemens van Blitterswijk ${ }^{\mathrm{a}}$, Lorenzo Moroni ${ }^{\mathrm{a}}$

${ }^{a}$ Department of Tissue Regeneration, MIRA Institute for Biomedical Technology and Technical Medicine, University of Twente, The Netherlands

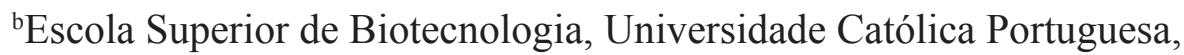
4200-072 Porto, Portugal 


\section{ABSTRACT}

Using the premise that surface topography influences cell behaviour, we patterned electrospun fibre meshes by nanoimprint lithography (NIL) at physiological temperatures of $42{ }^{\circ} \mathrm{C}$ or lower and low dwell times of 1-5 minutes. Different patterns - lines, grooves, circles and triangles and tones - pillars and pits - were imprinted. The density of the electrospun mesh was controlled by varying the deposition time. Fibre meshes obtained after 30 seconds of spinning were considered "low density" while meshes spun for 90 seconds were considered "high density". Pattern transfer was successful on low-density scaffolds imprinted at $37^{\circ} \mathrm{C}$ (Dwell time $=60 \mathrm{sec}$ onds, Pressure $=30$ bar) with a minimum of 25\% patterned area for circular pits and a maximum pattern coverage of $35 \%$ for triangular pillars. On high-density scaffolds imprinted at varying temperatures, an increase in temperature generally led to an increase in percentage of patterned area. Imprint temperatures of $37^{\circ} \mathrm{C}$ and $42{ }^{\circ} \mathrm{C}$ had comparable areas covered by patterns. Human mesenchymal stromal cells (hMSCs) were cultured on these patterned three-dimensional scaffolds for seven days. Circular and triangular pits showed significantly higher metabolic activity with increasing culturing time. Cell morphology and cytoskeletal arrangement were observed using scanning electron microscopy (SEM) and phalloidin staining of cytoskeleton. Image analysis of nuclear parameters showed significant differences in perimeter and circularity between non-patterned and patterned scaffolds. This study shows a fast and simple method to transfer patterns onto three-dimensional scaffolds and could be used as a system to study the effects of topography on cell activity or to transfer promising topographies from screens of other, twodimensional topographical libraries to create scaffolds for targeted applications. 


\section{INTRODUCTION}

The use of surface topography to steer cell behaviour for designing 1 medical implants with biologically instructive properties is currently widely pursued. As early as in the 1960s, Curtis and Varde [1] showed that fibroblasts grown on cylindrical glass fibres with diameters less than $100 \mu \mathrm{m}$ elongated and aligned with the fibres suggesting that shape can trigger cellular response. While one strategy to alter the behaviour of cells at their interface with biomaterials is to change surface roughness using techniques like plasma treatment or wet-chemical etching, another facet involves the use of tools from micro- or nanotechnology to create precise and highly reproducible structures on cellular or sub-cellular scale. The length scale of topographies used to study cell-material-interaction ranges from nanoscale pits [2-3] to complex micrometre-scale features [4-5]. Dalby et al. [2] and McMurray et al. [3] have recently demonstrated the use of biomaterial surfaces with controlled nanotopographies as cell culture substrates able to direct cell activity. By using electron-beam lithography to fabricate nanoscale features on polymers like polymethylmethacrylate (PMMA) and polycaprolactone (PCL), they were able to study the response of osteoprogenitor and mesenchymal stromal cells (MSCs) to the fabricated topographies. Their findings suggest that by merely altering the offset of features presented in a grid pattern, cells can be directed to switch between differentiation and proliferation. While $120 \mathrm{~nm}$ pits in a disordered square array with a $300 \mathrm{~nm}$ centre-to-centre spacing and dots randomly displaced by up to $50 \mathrm{~nm}$ on both axes from their position in a true square resulted in osteogenesis [2], an absolute square lattice symmetry (obtained by reducing offset as close to zero as possible) resulted in a surface favourable for MSC growth [3] without loss of multipotency.

Furthermore, high-throughput screening of topographical libraries has been performed to study the effect of topography on cell behaviour and potential for osteogenic differentiation, aiming to improve medical implant design [4-5]. Micrometre scale patterns comprising of circular and square pillars were arranged in different configurations to generate multiple patterns and study the effect of lateral feature size $(1-6 \mu \mathrm{m})$, feature distance $(1-6 \mu \mathrm{m})$ and feature height $(0.6-2.4 \mu \mathrm{m})$ on mineralisation of a MC3T3 cell line [4]. It was observed that feature height 
had a greater effect on mineralisation followed by size and spacing. Smaller structures and gaps also had higher osteopontin and osteocalcin expression, but exhibited delayed mineralisation. Patterns showing enhanced mineralisation and expression of osteogenic markers also had a decreased number of cells. Another high-throughput study generated patterns between 10 and $28 \mu \mathrm{m}$ using primitive shapes of circles, isosceles triangles and rectangles with dimensions ranging from 3 to $10 \mu \mathrm{m}$ in isolation or in various combinations. [5] While these studies evaluate cell-material-interactions on two-dimensional surfaces, in physiological conditions, cells are surrounded by extra-cellular matrix (ECM) and sense similar cues in such a three-dimensional environment. Recently, electrospun fibres have been widely used as scaffold material owing to their similarity in dimensions to native fibrils that are present in the ECM. Furthermore, these fibres can be easily produced and modified or post-processed. Microcontact printing by means of a polydimethylsiloxane (PDMS) stamp was used to transfer electrospun fibres onto a glass substrate and lithographic patterning was applied to create well-defined fibre arrays [6]. While such studies provide interesting tools and techniques for applications like nanodevices, the use of resists, developers, etching and chemical treatment are often not suitable for polymeric scaffolds intended for clinical applications. Moreover, studies on patterning of electrospun scaffolds by several methods usually pattern macroscopically and seldom on the length scales of single fibres [7-9]. These studies employ modifications to collector designs to achieve large scale patterning. Different approaches like three-dimensional collectors [7], soft lithography[8] and electroconductive templates [9] have been used for fabricating macro level patterned fibre scaffolds. In 2008, Di Benedetto et al. [10] demonstrated the patterning of electrospun fibres at length scales comparable to the fibre diameters for use as waveguides using room temperature nanoimprint lithography (NIL). NIL is a technique to transfer patterns from moulds onto substrates using controlled pressure, temperature and time. Chou and co-workers [11-12] described the nanoimprinting process on a polymethylmethacrylate (PMMA) substrate to create vias and trenches with a minimum size of $25 \mathrm{~nm}$ in width and $100 \mathrm{~nm}$ in depth using a $\mathrm{SiO}_{2}$ mould. Since NIL physically deforms a material to create patterns, an air-cushion-press arrangement [13] was suggested to improve pressure uniformity, yield and the lifetime of the 
mould.

In this study, we aimed at patterning three-dimensional scaffolds in the form of electrospun fibres on length scales comparable to fibre diameters using imprinting. The imprinting was performed between one and five minutes, either at room temperature $\left(27^{\circ} \mathrm{C}\right)$ or at physiological temperatures $\left(37-42^{\circ} \mathrm{C}\right)$. Polyactive ${ }^{\mathrm{TM}}$, a biocompatible polymer that has been used in various biomedical applications like tissue engineering [14-16], drug delivery [17] and as a cement restrictor for total joint arthroplasty [18], was electrospun and subsequently imprinted with patterns ranging from lines in the nano- and micrometre scale to geometric shapes likes circles and triangles with different tones (pillars and pits). Shapes and patterns trigger morphological changes of cell nuclei and cytoskeleton [19-20]. Hence, different patterns like circles, triangles and grooves were chosen for imprinting. The pattern dimensions covered the range from nanometre scale to micrometre scale previously studied. This approach would facilitate the transfer of promising topographies from high-throughput two-dimensional screens on to a three-dimensional substrate thereby realising the benefits of the high-throughput screens. Clinically relevant human mesenchymal stromal cells (hMSCs) were seeded on these scaffolds and their metabolic activity, adhesion and morphology on the patterned scaffolds were observed up to seven days in culture.

\section{MATERIALS AND METHODS}

DolyActive ${ }^{\mathrm{TM}}$ (PA) was provided by PolyVation BV, The Nether1 lands. Following an aPEOTbPBTc nomenclature, the composition used in this study was 300PEOT55PBT45, where (a) is the molecular weight in grams per mol of the starting polyethylene glycol (PEG) blocks used in the copolymerisation, while (b) and (c) are the weight ratios of the $\mathrm{PEOT}$ and $\mathrm{PBT}$ blocks, respectively.

PREPARATION OF SOLUTIONS FOR ELECTROSPINNING AND FABRICATION OF SCAFFOLDS

A $28 \%(\mathrm{w} / \mathrm{v})$ solution of PA was prepared in a mixture of chloroform $\left(\mathrm{CHCl}_{3}\right)$ and 1, 1, 1, 3, 3, 3-hexafluoro-2-propanol (HFIP) $(78 / 22 \mathrm{v} / \mathrm{v})$ and stirred overnight at room temperature before use. The solution was 
loaded into a syringe. The flow rate was controlled using a syringe pump (KDS 100, KD Scientific). A flexible polytetrafluoroethylene (PTFE) tube was used to connect the syringe to a needle on which a positive high voltage was applied using a corresponding voltage generator (D-ES60PN-5 WIQDPM, Gamma High Voltage Research Inc.). A stainless steel sheet was the collector (ground) and electrospun fibres were deposited on a metallised polymer film. A constant voltage of $12 \mathrm{kV}$ was applied while the distance and flow rate were fixed at 15 $\mathrm{cm}$ and $15 \mathrm{~mL} / \mathrm{hr}$. Temperature during spinning was around $20{ }^{\circ} \mathrm{C}$ and humidity varied between 30 and 50\%. Scaffolds were electrospun for 30 or 90 seconds for low and high density, respectively.

\section{PATTERNING ELECTROSPUN FIBRES USING NIL}

The imprinting of features on electrospun scaffolds was carried out by a dedicated nanoimprint lithography machine (NIL 6", Obducat). Patterns were etched on $\mathrm{Si}$ wafers and detailed information on the preparation of the wafers can be found elsewhere [21]. Briefly, custom silicon wafers functionalised with a perfluorodecyltrichlorosilane (FDTS) (ABCR) anti-stiction layer by vapour deposition containing different patterns served as imprint stamps and $6 \mathrm{~mm}$ electrospun discs were used as substrates. For all experiments, a pressure of 30 bar was applied. Imprinting temperatures and times were varied. To assess the effect of temperature on pattern coverage, imprinting was performed on high-density scaffolds at $27{ }^{\circ} \mathrm{C}, 37{ }^{\circ} \mathrm{C}$ and $42{ }^{\circ} \mathrm{C}$ for five minutes. To check the minimum dwell time required for patterning, a time course experiment was performed using a microgroove stamp at ambient temperatures at times ranging from a few seconds up to ten minutes. For cell culture studies, low-density scaffolds were imprinted at $37{ }^{\circ} \mathrm{C}$ for 60 seconds. Circles, triangles, micro- and nanogrooves were imprinted on electrospun fibres.

\section{SEM ANALYSIS OF PATTERNED SCAFFOLDS}

The morphology of electrospun fibres before and after patterning was observed using scanning electron microscopy (SEM) (XL 30 ESEMFEG, Philips/FEI). Fibre diameters were calculated from SEM micrographs by measuring 45 fibres per condition using Image J (National 
Institutes of Health, Bethesda, MD, USA). The SEM micrographs were also used for calculating pattern coverage.

\section{IMAGE ANALYSIS FOR EVALUATION OF PATTERNED AREA}

In order to distinguish the imprinted features, the fibres and the empty spaces between them during image analysis, pseudo colours were provided. The features were filled with black, the fibres with $50 \%$ grey and empty spaces with white. After the colour coding, the images were batch-processed and quantified using a customised plugin written and executed using Image $J$. The percentage of patterned area was obtained as a ratio of the area covered by patterns to the total area occupied by the fibres.

\section{PATTERN DEPTH}

The depth of the patterns imprinted on electrospun fibres were measured using an optical imaging profiler (PLu 2300, Sensofar-Tech) in confocal mode. Briefly, after Z-stack images were collected, a threepoint-term filter was used to flatten the area surrounding the pattern. Three depth measurements were made for a single feature, and twelve features per pattern were measured.

\section{ISOLATION OF HMSCS}

Bone marrow aspirates were obtained after written informed consent, and hMSCs were isolated and proliferated as described previously [22]. Briefly, aspirates were re-suspended by using 20 -gauge needles, plated at a density of $5 \times 10^{5}$ cells $/ \mathrm{cm}^{2}$ and cultured in hMSC proliferation medium containing $\alpha$-minimal essential medium (Life Technologies), $10 \%$ foetal bovine serum (Cambrex), $0.2 \mathrm{mM}$ ascorbic acid (Asap, Life Technologies), 2 mM L-glutamine (Life Technologies), 100 units/mL penicillin (Life Technologies), $10 \mu \mathrm{g} / \mathrm{mL}$ streptomycin (Life Technologies), and $1 \mathrm{ng} / \mathrm{mL}$ basic fibroblast growth factor (FGF) (Instruchemie). Cells were grown at $37^{\circ} \mathrm{C}$ in a humid atmosphere with $5 \% \mathrm{CO}_{2}$. Medium was refreshed twice a week, and cells were used for further sub-culturing or cryopreservation. Cells were trypsinised prior to seeding on scaffolds. 
IN VITRO CELL CULTURE ON PATTERNED THREE-DIMENSIONAL SCAFFOLDS

The in vitro experiments were performed with cells from a single donor at passage 4. Electrospun and imprinted discs were soaked in $100 \%$ ethanol for 30 minutes and dried in a laminar flow cabinet. The scaffolds were washed twice with sterile phosphate-buffered saline (PBS), transferred to a non-tissue-culture-treated 96-well plate (Nunc) and incubated at $37{ }^{\circ} \mathrm{C}$ in a humid atmosphere with $5 \% \mathrm{CO}_{2}$ for four hours in basic cell culture medium. Rubber O-rings (Eriks BV) were used to secure the discs in place and to prevent them from floating. After removing the medium, each scaffold was seeded with 2000 cells in 180 $\mu \mathrm{L}$ basic medium (proliferation medium without basic FGF). Medium was refreshed after each Alamar Blue measurement. In order to study the effect of patterned fibres on cells, low-density scaffolds were used for cell culture experiments as it was reasoned that a high density scaffold might mitigate the effect of the pattern as electrospun fibres, per se, are known to be attractive substrates for cell attachment and proliferation

\section{AlAMAR BLUE ASSAY FOR CELL METABOLISM}

Alamar Blue assay was used to assess the cell metabolism. Culture medium was replaced with medium containing $10 \%(\mathrm{v} / \mathrm{v})$ Alamar Blue solution (Biosource) and the cells were incubated at $37{ }^{\circ} \mathrm{C}$ for four hours. Fluorescence was measured at $590 \mathrm{~nm}$ on a multilabel plate reader (Victor ${ }^{3} 1420$, Perkin Elmer). Cell metabolism was analysed on day 1, 4 and 7 and the readout from the scaffolds $(n=3)$ was corrected with the blank from each group.

\section{ANALYSIS OF CELL MORPHOLOGY}

On day 7, media was removed and the scaffolds were washed twice with PBS and fixed in 10\% formalin for one hour. After rinsing with PBS, the scaffolds were dehydrated in a series of increasing ethanol concentrations $(70 \%, 80 \%, 90 \%, 96 \%$ and two times in $100 \%), 15$ minutes in each concentration, before being dried in a critical point dryer (CPD-030, Balzers). The samples were then sputter-coated with 
gold (108auto, Cressington) for observation on the SEM (Quanta 600F ESEM, FEI).

Samples for phalloidin staining were fixed in paraformaldehyde solution $(4 \% \mathrm{w} / \mathrm{v})$ for 10 minutes and rinsed with PBS to examine the cytoskeleton. The cell membrane was permeabilised by treating the sample with $0.01 \%$ Triton $\mathrm{X}-100$ for 5 minutes at room temperature and then washed with PBS twice. The samples were incubated for 20 minutes at room temperature with methanolic phalloidin stock solution (Invitrogen, Alexa Fluor 488 Phalloidin, excitation/emission: 495/518 $\mathrm{nm}$, dilution 1:100 in PBS). The samples were then washed twice with PBS and counterstained with a $300 \mathrm{nM}$ DAPI solution for 10 minutes to stain the nucleus. The samples were visualised using a fluorescent microscope (Eclipse E600, Nikon) fitted with the appropriate filters.

\section{ANALYSIS OF NUCLEAR PARAMETERS USING IMAGEJ}

The DAPI stained nuclei were analysed for shape and morphology using ImageJ. After converting the DAPI image into an 8-bit image, thresholding was performed to choose only the nuclei. Incomplete nuclei on the edges of the image were not considered and one image $(\sim 310 \mu \mathrm{m} \times 235 \mu \mathrm{m})$ per condition was used for the analysis. After this, shape parameters like area, perimeter, circularity and aspect ratio were analysed.

\section{STATISTICAL ANALYSIS}

One-way ANOVA with Tukey's multiple comparison post-hoc test was performed. The level of significance was set at 0.05. All data presented are expressed as mean \pm standard deviation.

\section{RESULTS}

FABRICATION, PATTERNING AND CHARACTERISATION OF ELECTROSPUN SCAFFOLDS

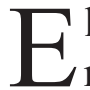
lectrospun scaffolds were successfully fabricated using the above mentioned parameters. The fibres had an average diameter of 5.98 $\pm 1.16 \mu \mathrm{m}$. A SEM micrograph of the fibres along with fibre diameter 
distribution is presented in the supporting information (Figure S1). A

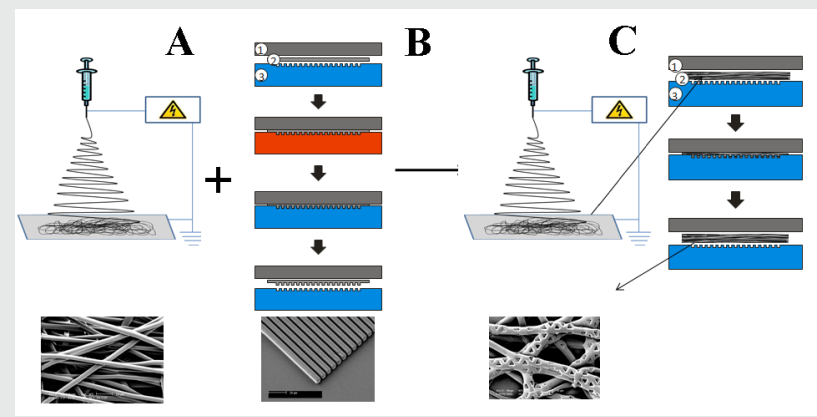

Fig 1: (A) Typical electrospinning setup where a polymer solution flows through a needle connected to a high voltage supply. The resulting fibres are collected on a grounded collector. (B) Thermal NIL process for patterning a thermoplastic polymer film (1) sealing foil separating the vacuum section of the NIL machine from its high pressure section, (2) polymer substrate/film to be imprinted, (3) silicon imprint stamp; for cold (blue) and heated (red) processes. (C) Electrospinning followed by NIL to prepare micro/nano patterned electrospun scaffolds where (2) is electrospun fibres to be imprinted. The last row shows SEM images of electrospun fibres, imprinted film and electrospun and imprinted fibres.

schematic procedure for patterning of electrospun fibres using imprinting is introduced in figure 1. SEM micrographs of different imprinted patterns on low-density scaffolds are shown in figure 2 . The periodicity, width and height of the ridges of the stamp to imprint the microgrooves (Figure 2A) was 15, 3.5 and $3 \mu \mathrm{m}$, respectively, while this was 500,150 and $100 \mathrm{~nm}$ for the nanogrooves (Figure 2B). Measurements on SEM images showed that the width and spacing for the imprinted grooves was $3.38 \pm 0.45 \mu \mathrm{m}$ and $11.2 \pm 0.27 \mu \mathrm{m}$ for the microgrooves, while $0.157 \pm 0.024 \mu \mathrm{m}$ and $0.262 \pm 0.032 \mu \mathrm{m}$ for the nanogrooves. While the microgrooves could be imprinted with a good pattern transfer, it was difficult to transfer the nanogrooves to deeper layers of the fibre mesh. The diameter of circular pillars and pits (Figures 2C, 2D) was measured to be $6.82 \pm 0.43 \mu \mathrm{m}$ and $4.424 \pm 0.3 \mu \mathrm{m}$, respectively. The side length of the triangular pillars and pits (Figures 2E, 2F) was measured to be $7.95 \pm 0.3 \mu \mathrm{m}$ and $4.81 \pm 0.54 \mu \mathrm{m}$, respectively.

Image analysis (supporting information figure S2) was used to quantify the area covered by patterns.). The area covered by circles and triangles in different tones was quantified and expressed as a percentage of total fibre area. Patterned area of all patterns was comparable on low density scaffolds imprinted at $37^{\circ} \mathrm{C}$ for 60 seconds (Figure 3A). 


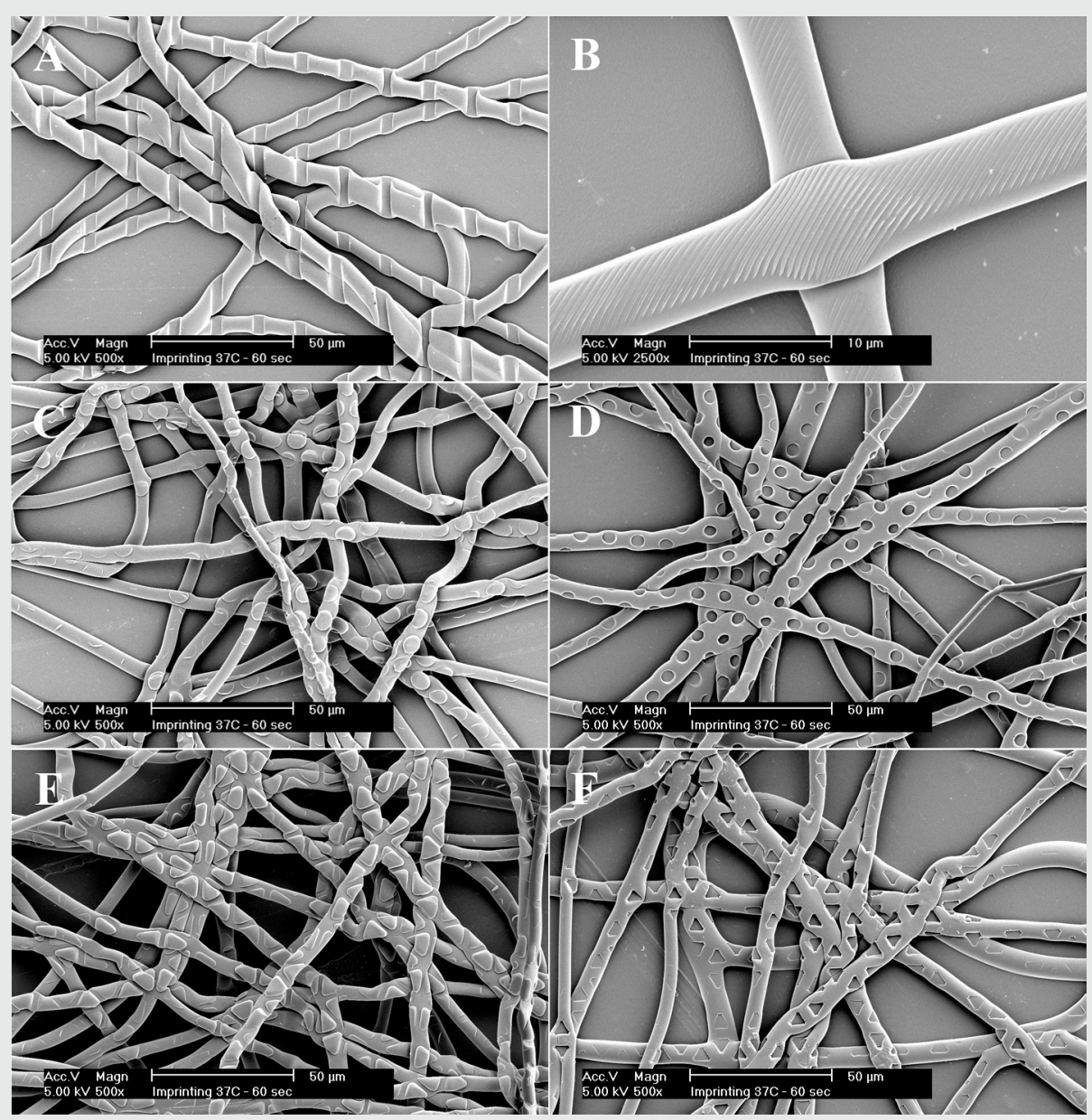

Figure 2: Electrospun fibers imprinted using NIL (37 ${ }^{\circ} \mathrm{C}, 60$ seconds). (A) Microgrooves, (B) Nanogrooves, (C) Circular pillars, (D) Circular pits, (E) Triangular pillars and (F) Triangular pits

While the average patterned area of the circular and triangular pillars was higher compared to pits, the differences were not statistically significant.

While low-density scaffolds serve as a model system for studying cell-pattern interactions on three-dimensional surfaces, scaffolds with higher fibre density and thickness are often used in in vitro experiments. Therefore, imprinting was also performed on high-density scaffolds at different temperatures for 300 seconds to analyse the effect of 
temperature on pattern transfer. Fibre diameter increased by $37 \%$ when trials were carried out at $42{ }^{\circ} \mathrm{C}$. For all patterns, increasing the imprint temperature from ambient or room temperature $\left(27-30{ }^{\circ} \mathrm{C}\right)$ to $42{ }^{\circ} \mathrm{C}$

\section{A Percentage of patterned area on electrospun fibres}
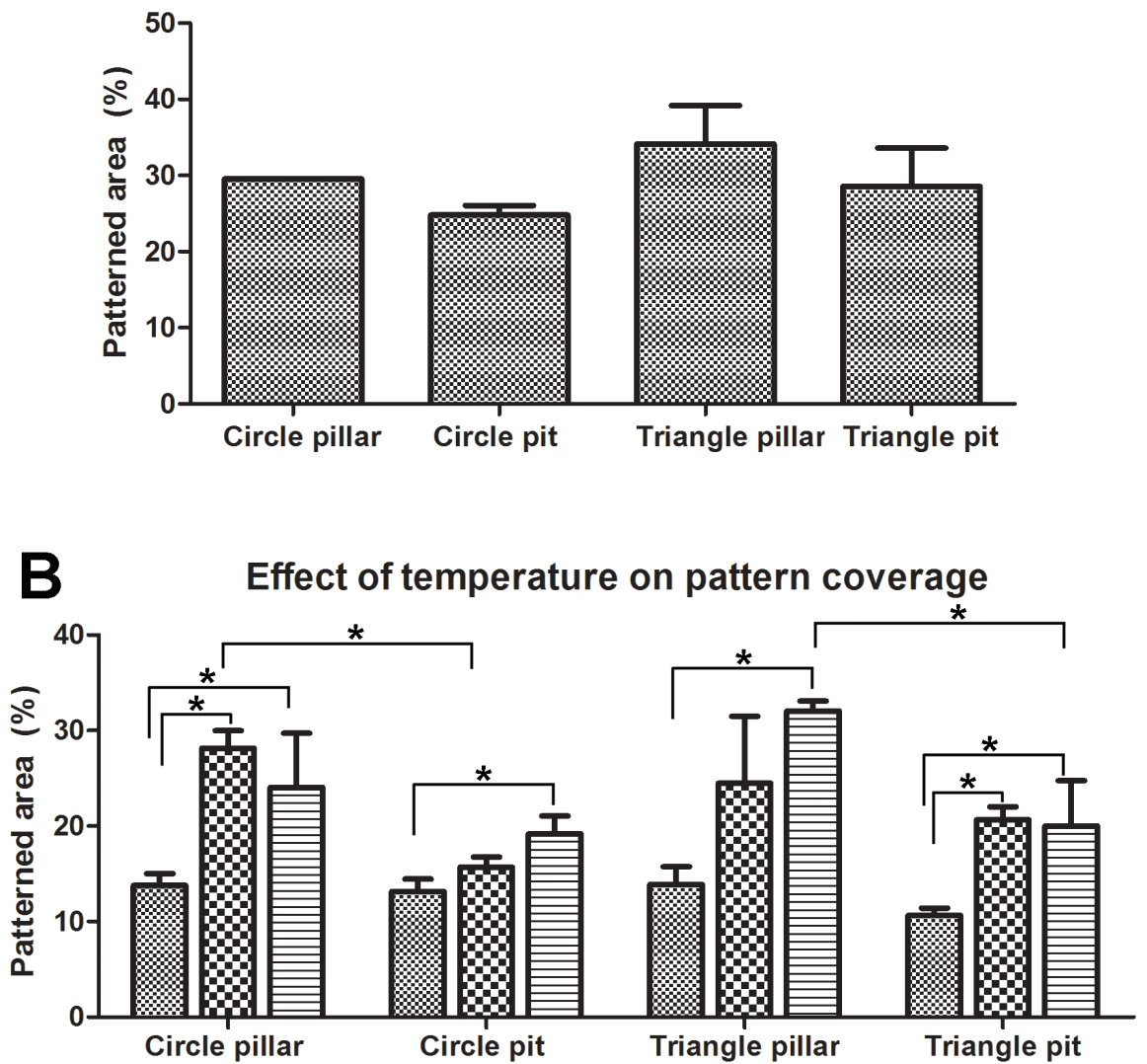

Room temperature $\left(27^{\circ} \mathrm{C}\right) \quad$ Physiological temperature $\left(37^{\circ} \mathrm{C}\right)$ $42^{\circ} \mathrm{C}$

Figure 3: Pattern coverage calculated using image analysis. (A) Patterned area on lowdensity electrospun fibre meshes imprinted at $37^{\circ} \mathrm{C}$ for 60 seconds. (B) Effect of temperature on pattern coverage for five minute imprint on high-density meshes. * represents $p<0.05$

led to a significant increase in pattern coverage (Figure 3B). Signifi- 
cant differences in pattern coverage were observed between ambient and physiological temperature for circular pillars and triangular pits while no significant differences in pattern coverage were observed for imprints performed at $37{ }^{\circ} \mathrm{C}$ and $42{ }^{\circ} \mathrm{C}$. When different patterns imprinted at the same temperature were analysed, no significant differences were observed for ambient temperature imprints. At $37^{\circ} \mathrm{C}$, the area covered by circular pillars was significantly higher compared to circular pits while triangular pillars covered more area than triangular pits when imprinted at $42{ }^{\circ} \mathrm{C}$.

Finally, the depth of the imprints on low-density scaffolds imprinted at $37{ }^{\circ} \mathrm{C}$ for 60 seconds was calculated and displayed in table 1 . On the wafer, the patterns were etched to a depth of $3 \mu \mathrm{m}$. No significant

\begin{tabular}{|c|c|}
\hline Pattern & Measured dimensions \\
\hline Nanogrooves & $\begin{array}{l}\text { Spacing - } 262 \pm 32 \mathrm{~nm} \\
\text { Width - } 157 \pm 24 \mathrm{~nm} \\
\text { Height - Not measurable }\end{array}$ \\
\hline Microgrooves & $\begin{array}{l}\text { Spacing }-11.2 \pm 0.27 \mu \mathrm{m} \\
\text { Width }-3.38 \pm 0.45 \mu \mathrm{m} \\
\text { Height }-2.07 \pm 0.4 \mu \mathrm{m}\end{array}$ \\
\hline Circle - Pillar & $\begin{array}{l}\text { Diameter }-6.82 \pm 0.43 \mu \mathrm{m} \\
\text { Height }-1.79 \pm 0.34 \mu \mathrm{m}\end{array}$ \\
\hline Circle - Pit & $\begin{array}{l}\text { Diameter }-4.424 \pm 0.3 \mu \mathrm{m} \\
\text { Height }-1.75 \pm 0.45 \mu \mathrm{m}\end{array}$ \\
\hline Triangle - Pillar & $\begin{array}{l}\text { Side length }-7.95 \pm 0.3 \mu \mathrm{m} \\
\text { Height }-1.96 \pm 0.36 \mu \mathrm{m}\end{array}$ \\
\hline Triangle - Pit & $\begin{array}{l}\text { Side length }-4.81 \pm 0.54 \mu \mathrm{m} \\
\text { Height }-1.99 \pm 0.4 \mu \mathrm{m}\end{array}$ \\
\hline
\end{tabular}

Table 1 Measured attributes of imprinted patterns 


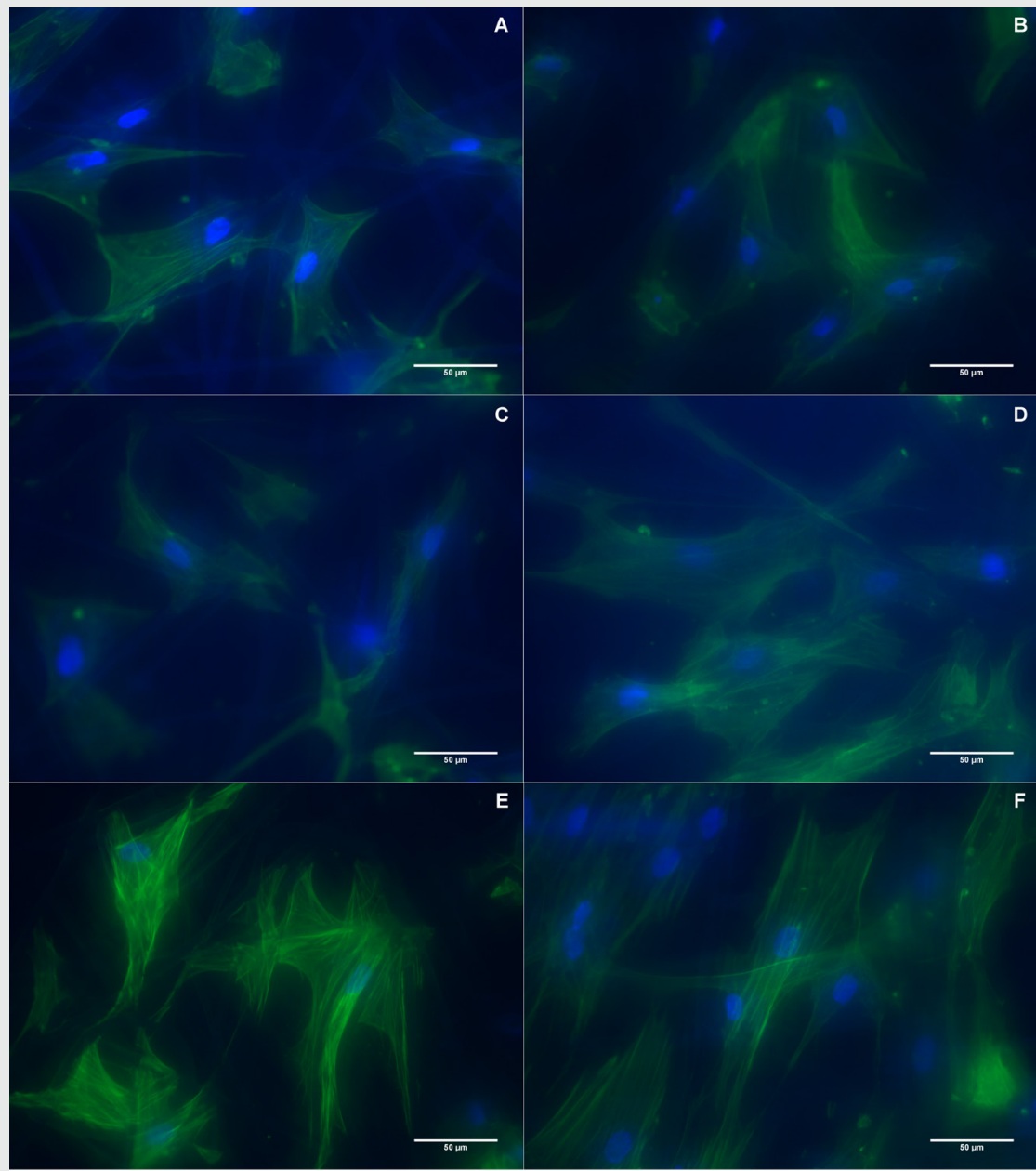

Analysis of nuclear parameters
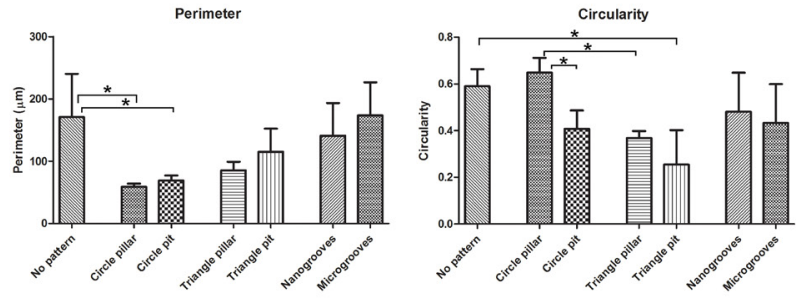

Figure 4: Staining of nucleus (blue) and cytoskeleton (green) on patterned scaffolds and analysis of nuclear parameters (A) Circle pillar, (B) Circle pit (C) Triangle pillar, (D) Triangle pit, $(E)$ Nanogrooves and $(F)$ Microgrooves. Scale bar $50 \mu m(G)$ Shape parameters of the nucleus obtained through image analysis. * represents $p<0.05$ 
differences were observed in the depth of various patterns although a trend of lower depth for circular patterns compared to triangular ones was observed.

\section{RESPONSE OF HMSCS TO PATTERNED ELECTROSPUN SCAFFOLDS}

To study cell-material interactions on patterned scaffolds, we evaluated the metabolic activity and cell morphology of hMSCs seeded on these scaffolds. Metabolic activity of cells cultured on different scaffolds was assessed using Alamar Blue assay on days 1, 4 and 7 (supporting information figure S3). No significant differences were observed between the different scaffolds during the course of culture. Microgrooves and "pit" scaffolds with circular and triangular patterns showed significant differences in metabolic activity over time. The circular pit and microgrooved scaffolds had a significantly higher metabolic activity on day 7 compared to day 1 . For the triangular pit scaffolds, a significant difference in metabolic activity was observed during culturing time. No significant differences were observed between non-patterned electrospun fibre meshes and fibre meshes pressed with a non-patterned wafer (data not shown).

After the culture period, scaffolds were visualised using SEM to study cell morphology (supporting information figure S5). Cells attached on all surfaces and interacted with the different patterns. The cells engulfed various patterns and "grew" into them in case of the "pit" tone. Nucleus and cytoskeletal arrangement were visualised using fluorescent staining (Figure 4). Actin cytoskeletal arrangement of cells on different patterned scaffolds showed a generally elongated morphology. The cytoskeleton of cells in the grooved patterns appeared to be more stretched compared to other patterns. The DAPI images were used to analyse various shape and morphological parameters of the nucleus using image analysis (Figure 4G). Significant differences were observed for perimeter and circularity of cell nuclei on different surfaces. Cells on scaffolds patterned with circular features had a significantly lower nuclear perimeter compared to unpatterned control scaffolds. Circularity of nuclei on triangular pits was significantly lower than the control while cells on circular pillars had a significantly higher circularity 
of the nucleus compared to circular pits and triangular pillars. These results indicate that it might be possible to alter nucleus and cell morphology by altering pattern shape (circle vs. triangle) or tone (pillar vs. pit), which could eventually result in different cellular responses.

\section{DISCUSSION}

T $\mathrm{n}$ this study, we have combined two widely used technologies from different fields to create a novel process that could be beneficial for biomedical applications. The electrospinning process is more than a century old [23] and has a wide variety of applications in areas of filtration, biosensors, protective textiles and biomedical engineering [24]. In the past decade, widespread applications of electrospinning in tissue engineering resulted in the fabrication of non-woven networks that mimic ECM-like structures. Imprinting processes such as NIL or micro-contact printing are used for biological applications like DNA and protein microarrays, protein patterning and tissue engineering to study effect of patterns and surfaces on cell behaviour [25]. Yang and Leong [26] mention that high temperatures and pressures needed for imprinting thermoplastic materials could lead to a reduced throughput while fabricating nanoscale surfaces for regenerative medicine. Our process, using ambient or physiological temperatures results in successful pattern transfer and could potentially lead to enhanced throughput when promising topographies are discovered.

A fine balance between achieving pattern transfer and maintaining the shape of the fibres exists. High imprint temperatures can have two detrimental effects when used on electrospun fibres. High temperatures, combined with high pressures and long dwell times during NIL, would eventually lead to flattening of electrospun fibres, resulting in loss of their three-dimensional shape. Combining synthetic polymers with biological components present in the ECM such as collagen type I, fibronectin and laminin, or standalone use of such proteins, is becoming a common strategy for tissue regeneration applications to impart further biological activity to the fabricated meshes [27-30]. As the denaturation of such proteins can start at temperatures as low as $41-42{ }^{\circ} \mathrm{C}$, we believe that our results demonstrating pattern transfer at ambient and physiological conditions are highly relevant for diverse biomedical applications and have the potential to be translated to naturally occurring 
biological materials as well with the possibility of inking or stamping specific molecules in defined spots using electrospinning and imprinting technologies.

Analysis of pattern coverage data shows that it is possible to increase the patterned area either by increasing the imprint temperature or by reducing the density of the fibre mesh used. Other possibilities to increase patterned area would be an increase in dwell time or pressure. Human MSCs are widely used in tissue engineering and regenerative medicine applications due to their potential to aid in the regeneration of multiple tissues. In the current study, in vitro culture of hMSCs on patterned scaffolds demonstrated cell attachment, viability and proliferation and changes in nuclear shape were observed due to the presence of the imprinted patterns. Studies [31-33] have shown that nuclear shape is altered when cells were cultured on patterned surfaces suggesting a correlation between nucleus and cytoskeletal arrangement and mechanical transduction resulting from "sensing" the topographical cues. Recently, geometric cues were used to alter the fate of MSCs [34]. A flower-like shape with convex curves led to MSCs preferentially differentiating to adipocytes while a star shape led to differentiation into the osteoblastic lineage. These examples demonstrate the possible advantages of using surface topographical cues on twodimensional substrates to impart instructive signals and guide cell fate. A recent study used microfluidic techniques to code individual microfibres made from alginate to incorporate various physicochemical cues in terms of composition and topography [35]. Neurons showed more aligned neurite outgrowth on fibres coded with grooves in comparison to smooth ones. Furthermore, the study showed that chemical coding using a chemo attractant could lead to cell migration in a culture. In our study, we have presented a fast and facile method to transfer topographical cues from two- to three-dimensional scaffolds for applications in regenerative medicine. While changes in cellular morphology were observed, further studies are needed to dissect the role of specific surface topographies on cells cultured on patterned 3D scaffolds.

Plasma treatment using oxygen (among other gases) plasma has been used to modify roughness and generally improve the hydrophilicity of the substrate [36-37]. While this can be controlled by varying factors like treatment time and power, limited spatial control can be 
achieved. Furthermore, even with the use of non-reactive gases like argon, it is extremely difficult to decouple the changes in topography and surface chemistry. Therefore, by combining plasma treatment and

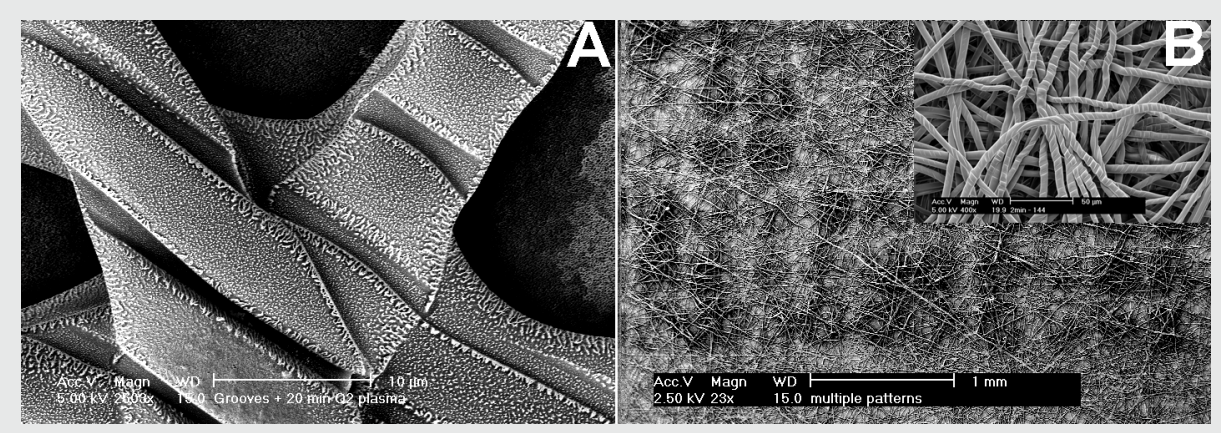

Figure 5: (A) Combination of a conventional method to create topography (plasma) with NIL patterning to create regions with different properties. (B) The use of NIL patterned electrospun surfaces as high throughput screens. White circles indicate islands of patterned surfaces and inset shows a pattern of larger scale $(\sim 100 \mu \mathrm{m})$ that could be used to study cell organisation and response to larger scale patterns.

imprinting of electrospun fibres, one can envision the possibilities to create defined regions of tailored roughness and wettability (Figure $5 \mathrm{~A})$. Surfaces with variable wettability are found in nature, and Zhai and co-workers [38] created hydrophilic domains on superhydrophobic surfaces that mimicked the water collecting mechanism of the Stenocara beetle. Hence, a combination of plasma treatment and patterning of electrospun fibres (Figure 5A) or microcontact printing could find potential applications in other areas like protective clothing, biosensors, filtration devices and affinity columns [24, 39].

Another potential application is in high-throughput screening of cellmaterial interactions in three dimensions. Starting with arrays using different monomers [40] to test cell-material interactions, screening of biomaterials has progressed to testing different polymers [41] and currently the use of different topographies [4-5]. These studies provide valuable information for use in medical implant and scaffold design for various other applications. Yet, such studies are confined to two-dimensional substrates. As shown in figure $5 \mathrm{~B}$, it would be also possible to imprint discrete areas with larger scale patterns (Figure 5B inset) to study cell and tissue formation as a function of geometric signals, 
thus expanding high-throughput screening of cell-material interactions from two-dimensional surfaces to three-dimensional, ECM-like surface morphology.

While we have presented a novel way to pattern electrospun fibres at orders of magnitude comparable to or lower than the fibre diameter, the process will have to be further optimised. One of the key points to be addressed is the pattern penetration to deeper layers. When highdensity scaffolds were imprinted, pattern transfer to deeper layers of the scaffold was limited. Although layers below the topmost layer were imprinted, the whole mesh could not be imprinted. One possible solution to this limitation would be to stack several patterned sheets as stacking of porous sheets [42] has previously been demonstrated as a possible strategy to build tissue engineered constructs. Alternatively, alternating steps of fibre deposition and imprinting could be envisioned when the two technologies would be combined in a single system. Other possibilities include the application of wafers on both sides of the electrospun mesh, leading to imprinting from both sides and deeper etching of the mould.

\section{CONCLUSIONS}

A simple and fast method to create versatile patterns on electrospun ised for morphology and pattern coverage. hMSCs cultured on these scaffolds attached and proliferated over time, and exhibited differences in morphology and nuclear parameters when compared to unpatterned scaffolds. Such patterned scaffolds could be potential tools to study the effect of topography on cell activity on three-dimensional surfaces and evaluate whether hit patterns from high-throughput screening of topographical libraries transferred on three-dimensional scaffolds confirm cell-material interactions found on two-dimensional substrates.

\section{ACKNOWLEDGEMENTS}

The authors wish to thank Mr. Daniel Leisen for designing the 1 mould. The authors also thank University of Eindhoven for use of their SEM and optical profiler facilities. 


\section{REFERENCES}

1. Curtis AS, Varde M. Control of Cell Behavior: Topological Factors. J Natl Cancer Inst 1964;33:15-26.

2. Dalby MJ, Gadegaard N, Tare R, Andar A, Riehle MO, Herzyk $\mathrm{P}$, et al. The control of human mesenchymal cell differentiation using nanoscale symmetry and disorder. Nat Mater 2007;6(12):997-1003.

3. McMurray RJ, Gadegaard N, Tsimbouri PM, Burgess KV, McNamara LE, Tare R, et al. Nanoscale surfaces for the long-term maintenance of mesenchymal stem cell phenotype and multipotency. Nat Mater 2011;10(8):637-644.

4. Lovmand J, Justesen E, Foss M, Lauridsen RH, Lovmand M, Modin C, et al. The use of combinatorial topographical libraries for the screening of enhanced osteogenic expression and mineralization. Biomaterials 2009;30(11):2015-2022.

5. Unadkat HV, Hulsman M, Cornelissen K, Papenburg BJ, Truckenmuller RK, Post GF, et al. An algorithm-based topographical biomaterials library to instruct cell fate. Proc Natl Acad Sci U S A 2011;108(40):16565-16570.

6. Shi J, Wang L, Chen Y. Microcontact Printing and Lithographic Patterning of Electrospun Nanofibers. Langmuir 2009;25(11):60156018.

7. Zhang DM, Chang J. Electrospinning of Three-Dimensional Nanofibrous Tubes with Controllable Architectures. Nano Lett 2008;8(10):3283-3287.

8. Dempsey DK, Schwartz CJ, Ward RS, Iyer AV, Parakka JP, Cosgriff-Hernandez EM. Micropatterning of Electrospun Polyurethane Fibers Through Control of Surface Topography. Macromol Mater Eng 2010;295(11):990-994.

9. Zhang DM, Chang J. Patterning of electrospun fibers using electroconductive templates. Adv Mater 2007;19(21):3664-+.

10. Di Benedetto F, Camposeo A, Pagliara S, Mele E, Persano L, Stabile R, et al. Patterning of light-emitting conjugated polymer nanofibres. Nat Nanotechnol 2008;3(10):614-619. 
11. Chou SY, Krauss PR, Renstrom PJ. Imprint of Sub-25 Nm Vias and Trenches in Polymers. Appl Phys Lett 1995;67(21):3114-3116.

12. Chou SY, Krauss PR, Renstrom PJ. Imprint lithography with 25-nanometer resolution. Science 1996;272(5258):85-87.

13. Gao H, Tan H, Zhang W, Morton K, Chou SY. Air cushion press for excellent uniformity, high yield, and fast nanoimprint across a 100 mm field. Nano Lett 2006;6(11):2438-2441.

14. Du C, Meijer GJ, van de Valk C, Haan RE, Bezemer JM, Hesseling SC, et al. Bone growth in biomimetic apatite coated porous Polyactive((R)) 1000PEGT70PBT30 implants. Biomaterials 2002;23(23):4649-4656.

15. Nandakumar A, Yang L, Habibovic P, van Blitterswijk C. Calcium Phosphate Coated Electrospun Fiber Matrices as Scaffolds for Bone Tissue Engineering. Langmuir 2010;26(10):7380-7387.

16. Woodfield TBF, Malda J, de Wijn J, Peters F, Riesle J, van Blitterswijk CA. Design of porous scaffolds for cartilage tissue engineering using a three-dimensional fiber-deposition technique. Biomaterials 2004;25(18):4149-4161.

17. Sohier J, van Dijkhuizen-Radersma R, de Groot K, Bezemer JM. Release of small water-soluble drugs from multiblock copolymer microspheres: a feasibility study. Eur J Pharm Biopharm 2003;55(2):221228.

18. Bulstra SK, Geesink RG, Bakker D, Bulstra TH, Bouwmeester SJ, van der Linden AJ. Femoral canal occlusion in total hip replacement using a resorbable and flexible cement restrictor. J Bone Joint Surg Br 1996;78(6):892-898.

19. Curtis ASG, Clark P. The Effects of Topographic and Mechanical-Properties of Materials on Cell Behavior. Crit Rev Biocompat 1990;5(4):343-362.

20. Dalby MJ. Topographically induced direct cell mechanotransduction. Med Eng Phys 2005;27(9):730-742.

21. Truckenmuller R, Giselbrecht S, Escalante-Marun M, Groenendijk M, Papenburg B, Rivron N, et al. Fabrication of cell container arrays with overlaid surface topographies. Biomed Microdevices 2011. 
22. Both SK, Van der Muijsenberg AJC, Van Blitterswijk CA, De Boer J, De Bruijn JD. A rapid and efficient method for expansion of human mesenchymal stem cells. Tissue Eng 2007;13(1):3-9.

23. Teo WE, Ramakrishna S. A review on electrospinning design and nanofibre assemblies. Nanotechnology 2006;17(14):R89-R106.

24. Bhardwaj N, Kundu SC. Electrospinning: A fascinating fiber fabrication technique. Biotechnol Adv 2010;28(3):325-347.

25. Truskett VN, Watts MP. Trends in imprint lithography for biological applications. Trends Biotechnol 2006;24(7):312-317.

26. Yang Y, Leong KW. Nanoscale surfacing for regenerative medicine. Wiley Interdiscip Rev Nanomed Nanobiotechnol 2010;2(5):478495.

27. Li C, Vepari C, Jin HJ, Kim HJ, Kaplan DL. Electrospun silk-BMP-2 scaffolds for bone tissue engineering. Biomaterials 2006;27(16):3115-3124.

28. Shih YR, Chen CN, Tsai SW, Wang YJ, Lee OK. Growth of mesenchymal stem cells on electrospun type I collagen nanofibers. Stem Cells 2006;24(11):2391-2397.

29. Dubey G, Mequanint K. Conjugation of fibronectin onto threedimensional porous scaffolds for vascular tissue engineering applications. Acta Biomater 2011;7(3):1114-1125.

30. Neal RA, McClugage SG, Link MC, Sefcik LS, Ogle RC, Botchwey EA. Laminin Nanofiber Meshes That Mimic Morphological Properties and Bioactivity of Basement Membranes. Tissue Eng Part C-Me 2009;15(1):11-21.

31. Dalby MJ, Riehle MO, Yarwood SJ, Wilkinson CD, Curtis AS. Nucleus alignment and cell signaling in fibroblasts: response to a micro-grooved topography. Exp Cell Res 2003;284(2):274-282.

32. Thomas CH, Collier JH, Sfeir CS, Healy KE. Engineering gene expression and protein synthesis by modulation of nuclear shape. Proc Natl Acad Sci U S A 2002;99(4):1972-1977.

33. Yim EK, Pang SW, Leong KW. Synthetic nanostructures inducing differentiation of human mesenchymal stem cells into neuronal lineage. Exp Cell Res 2007;313(9):1820-1829. 
34. Kilian KA, Bugarija B, Lahn BT, Mrksich M. Geometric cues for directing the differentiation of mesenchymal stem cells. P Natl Acad Sci USA 2010;107(11):4872-4877.

35. Kang E, Jeong GS, Choi YY, Lee KH, Khademhosseini A, Lee SH. Digitally tunable physicochemical coding of material composition and topography in continuous microfibres. Nat Mater 2011.

36. Hanson AD, Wall ME, Pourdeyhimi B, Loboa EG. Effects of oxygen plasma treatment on adipose-derived human mesenchymal stem cell adherence to poly(L-lactic acid) scaffolds. J Biomat Sci-Polym E 2007;18(11):1387-1400.

37. Martins A, Pinho ED, Faria S, Pashkuleva I, Marques AP, Reis RL, et al. Surface modification of electrospun polycaprolactone nanofiber meshes by plasma treatment to enhance biological performance. Small 2009;5(10):1195-1206.

38. Zhai L, Berg MC, Cebeci FC, Kim Y, Milwid JM, Rubner MF, et al. Patterned superhydrophobic surfaces: toward a synthetic mimic of the Namib Desert beetle. Nano Lett 2006;6(6):1213-1217.

39. Ramakrishna S, Fujihara K, Teo WE, Yong T, Ma ZW, Ramaseshan R. Electrospun nanofibers: solving global issues. Mater Today 2006;9(3):40-50.

40. Anderson DG, Levenberg S, Langer R. Nanoliter-scale synthesis of arrayed biomaterials and application to human embryonic stem cells. Nat Biotechnol 2004;22(7):863-866.

41. Anderson DG, Putnam D, Lavik EB, Mahmood TA, Langer R. Biomaterial microarrays: rapid, microscale screening of polymer-cell interaction. Biomaterials 2005;26(23):4892-4897.

42. Papenburg BJ, Liu J, Higuera GA, Barradas AM, de Boer J, van Blitterswijk CA, et al. Development and analysis of multi-layer scaffolds for tissue engineering. Biomaterials 2009;30(31):6228-6239. 


\section{SUPPORTING INFORMATION}
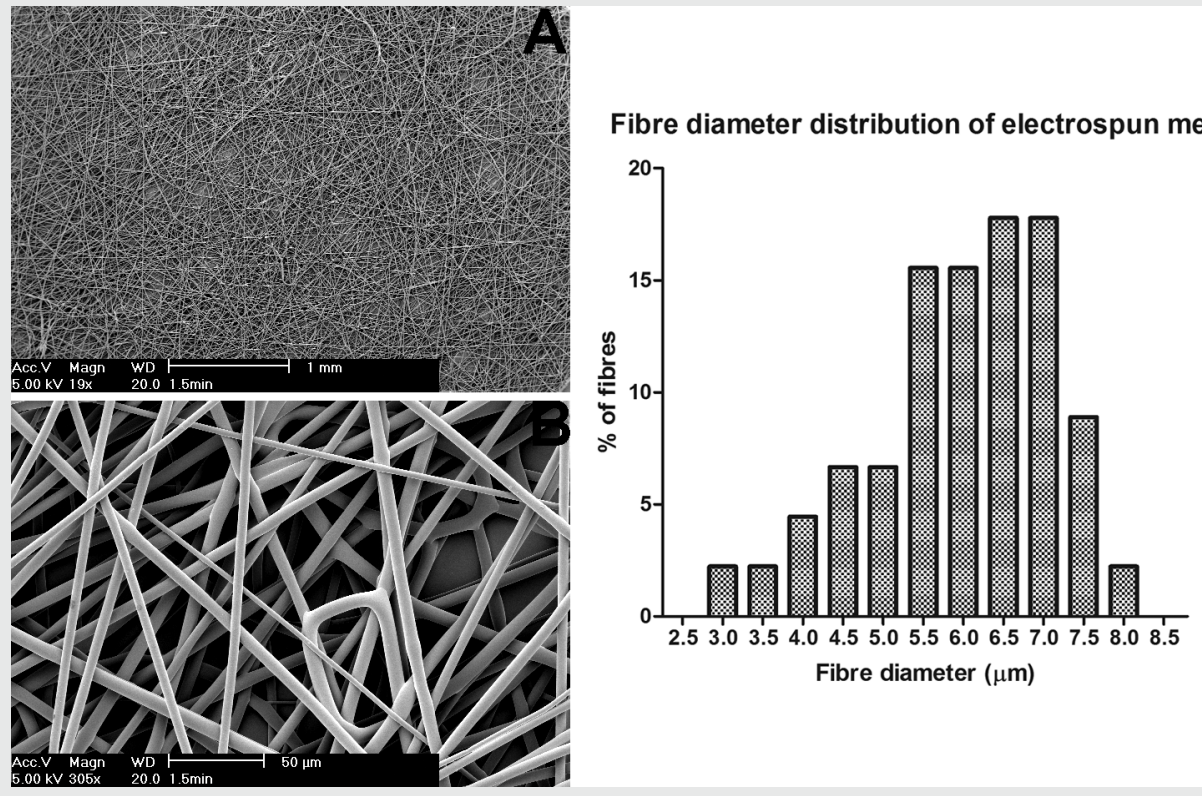

Fig S1: Electrospun fibres of PolyActive TM in low (A) and high magnification (B) Histogram showing frequency distribution of fiber diameter (C) Mean fiber diameter was calculated to be $5.98 \pm 1.16 \mu \mathrm{m}$ 


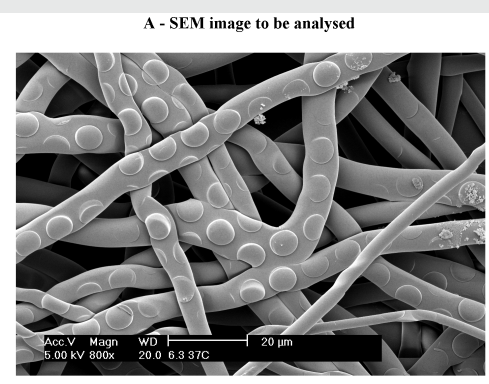

B - Cropped and processed image ready for analysis

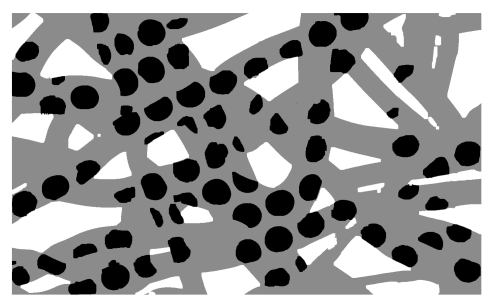

Image Processing

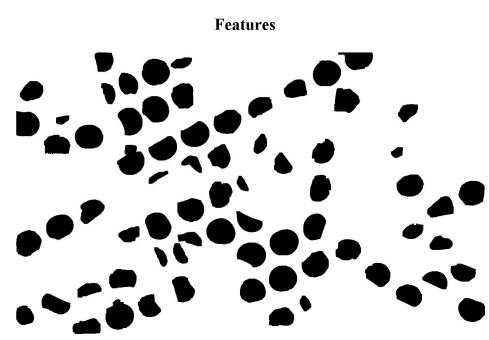

C - Results

Fibres without features

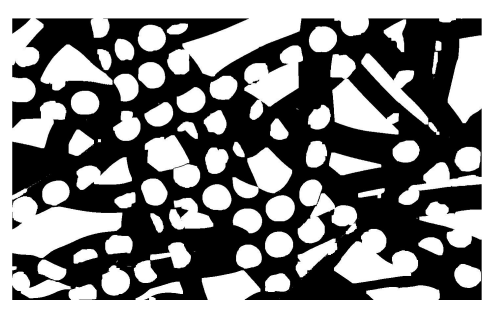

Quantification of area covered by patterns
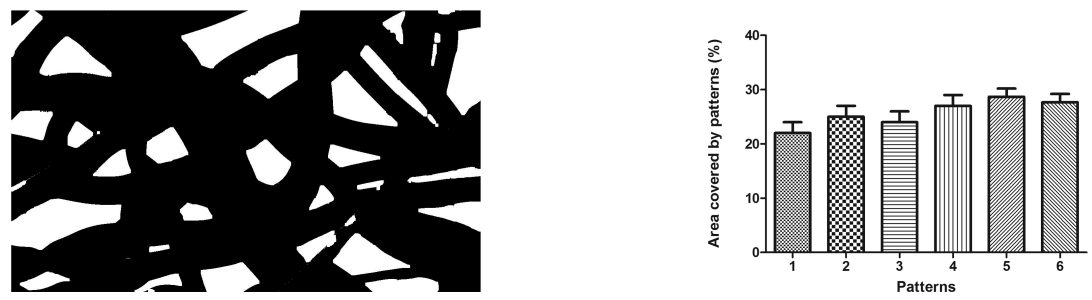

Figure S2: Workflow depicting image analysis of patterned fibers. (A) SEM image to be analysed, (B) Cropped and processed image with color coding. Fibers - grey, Patterns - black and free space - white. (C) Outcome of image processing with different images for patterns, fibers and total area and quantified data regarding pattern coverage. 


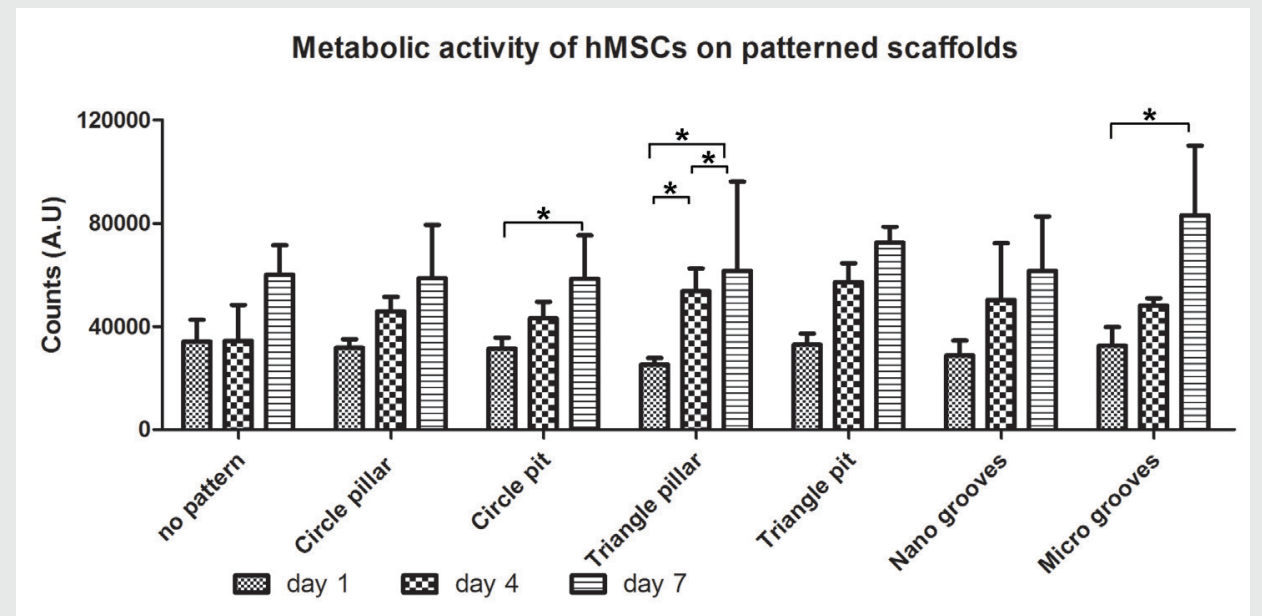

Figure S3: Metabolic activity of cells cultured on different scaffolds on days 1, 4 and 7 assessed by Alamar blue measurements. Data shown for $n=3$ samples and expressed as mean \pm standard deviation. $*$ represents $p<0.05$

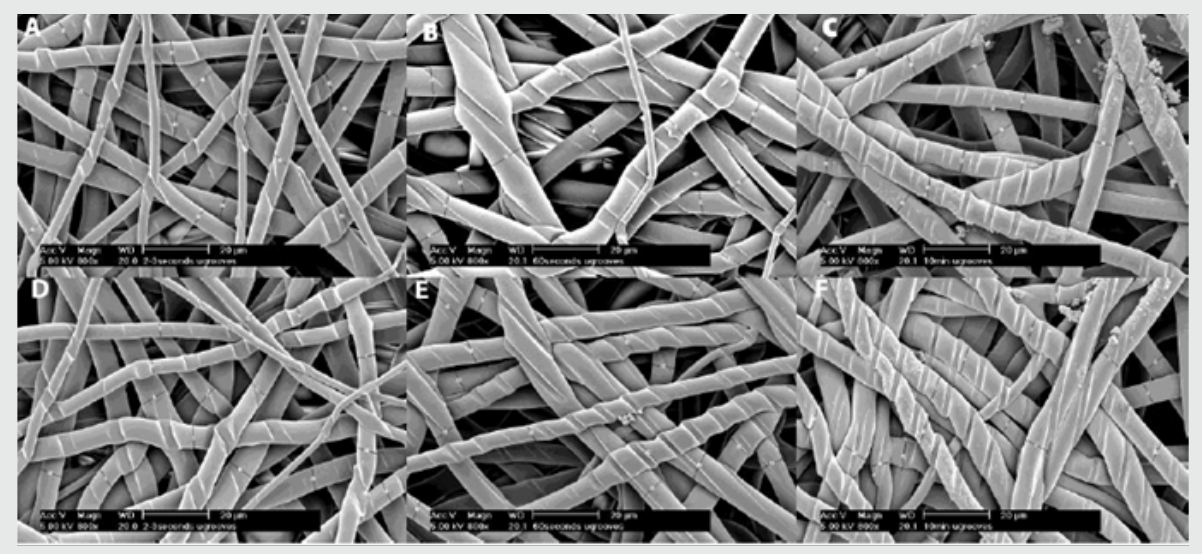

Figure S4: Effect of imprinting time on microgrooves. $(A, D) 2$ seconds, $(B, E) 60$ seconds and (C,F) 600 seconds. While patterns are already transferred after few seconds, they appear faint even in the top layers. Imprinting for 60 seconds or more ensures better pattern transfer as observed in $B, C, E$ and $F$. 

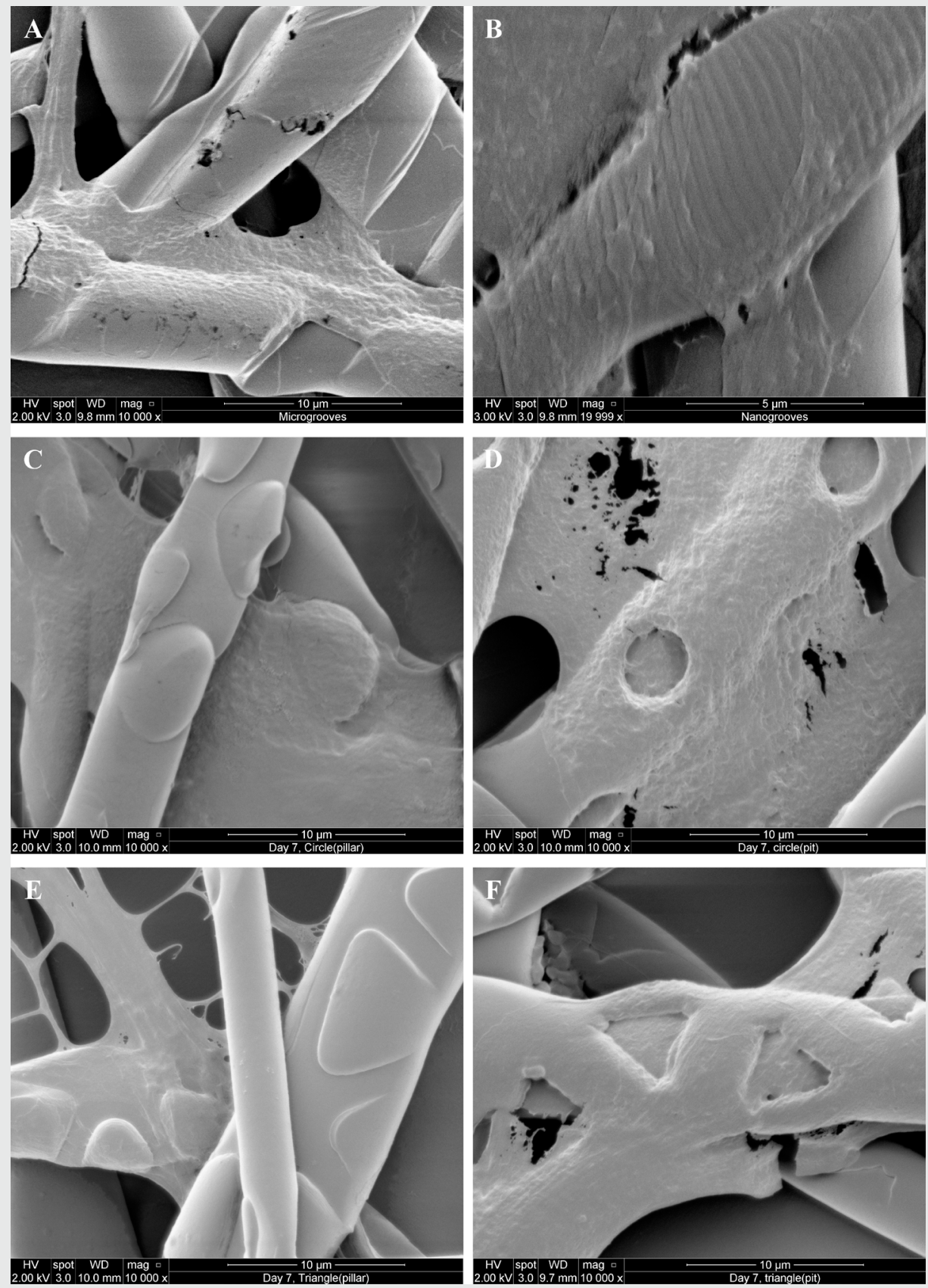

Figure S5: Cell morphology on various scaffolds on day 7 using SEM. (A) Microgrooves (B) Nanogrooves (C) Circular pillars (D) Circular pits. (E) Triangular pillars and (F) Triangular pits. $A, C, D, E$ and $F$ scale bar $=10 \mu \mathrm{m}$ and $B$ scale bar $=5 \mu \mathrm{m}$ 


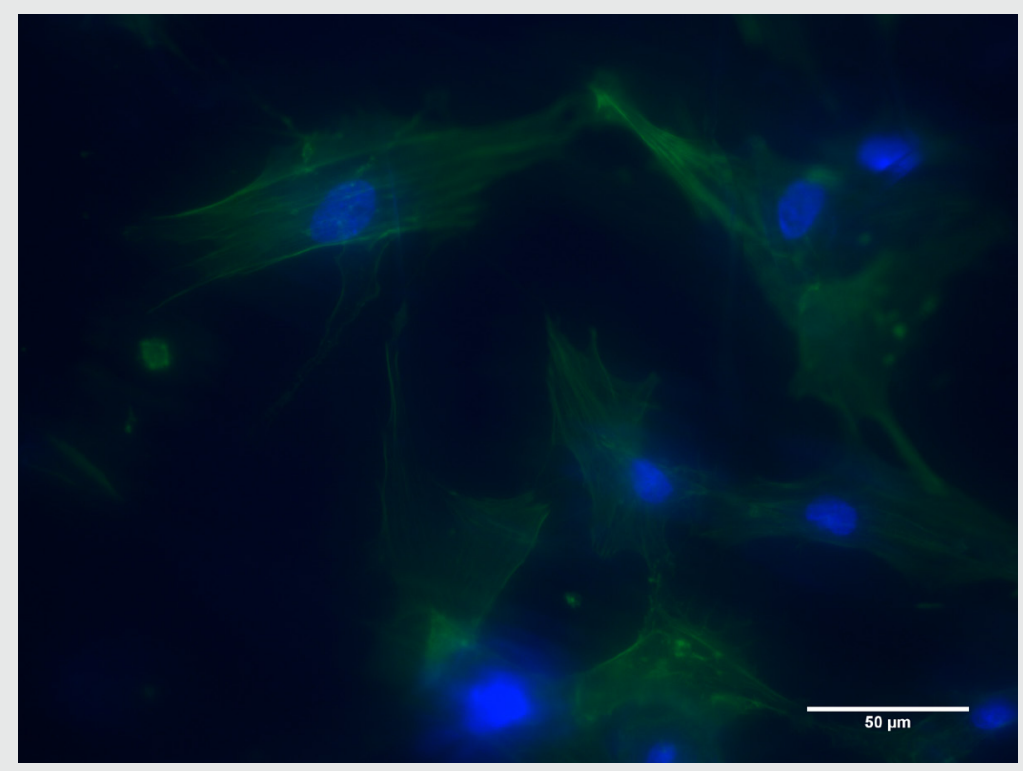

Figure S6: Staining of nucleus (blue) and cytoskeleton (green) on unpatterned electrospun scaffolds. Scale bar $50 \mu \mathrm{m}$ 


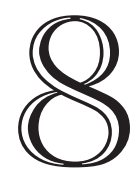

\section{General discussion and conclusions}

If you can meet with Triumph and Disaster And treat those two impostors just the same;

"IF" - Rudyard Kipling 
$\mathrm{T}$ the last few decades, tissue engineering has been explored as an alternative approach to using autologous grafts that are limited by available amounts that can be harvested. Orthopaedic and cranio-maxillo-facial surgeries are excellent examples of applications where there is a growing need for alternatives to natural bone grafts in the form of synthetic bone graft substitutes and tissue engineered constructs. As stated in the introductory chapter, the broad aim of this thesis is to create improved scaffolds for bone tissue engineering. The strategy used to achieve this outcome was to combine different biomaterials and to employ different scaffold fabrication techniques. Surface of scaffolds produced by rapid prototyping and/or electrospinning was functionalised through deposition of calcium phosphate (Ca-P) coatings, plasma treatment or imprinting. Part A (chapters 2-5) focused on incorporating $\mathrm{Ca}-\mathrm{P}$ ceramics as bulk materials or as coatings in polymeric scaffolds to exploit the processibility of polymers and the bioactivity of $\mathrm{Ca}-\mathrm{P}$, with the rationale of mimicking the composite nature of bone. In part B (chapters 6 and 7), electrospun fibres were postprocessed by plasma treatment and imprinting, based on the hypothesis that surface cues can modify cellular response. A general discussion on results obtained with the above mentioned strategies is discussed in the following sections.

\section{BIOMIMETIC CALCIUM PHOSPHATE COATINGS TO ENHANCE BIOACTIVITY OF POLYMERIC SCAFFOLDS}

$\mathrm{C}$ a-P coatings have been used in various forms [1-4] (plasma sprayed, electrodeposited, biomimetic coatings etc.) to coat mainly metallic implants to improve the bonding with bone [5-7]. While plasma spraying can only be applied to thermally stable Ca-P phases like hydroxyapatite (HA) due to the high temperatures involved, other biologically relevant and metastable phases like octacalcium phosphate (OCP) and bone-like carbonated apatite (CA) cannot be produced, and require methods that take place at near-physiological conditions, such as solution based biomimetic coating methods [8]. This method, based on immersion of substrates into simulated body fluids, allows the coating of complex geometric shapes and porous scaffolds and can be used to coat various substrates like metals and polymers. Furthermore, it is possible to incorporate growth factors [9] and bioinorganics [10] into 
the coatings thereby further enhancing their bioactivity.

In chapter 2, the feasibility of coating electrospun polymeric fibres with Ca-Ps using the biomimetic coating method was demonstrated. An OCP coating with some carbonate was deposited on electrospun PA fibres. The coating method applied was shown to be suitable for providing such a three dimensional mesh with a layer of OCP, both on the periphery and in their interior, however the coating was not completely homogenous in thickness and some agglomerates were noticed. OCP was chosen as it is considered to be a precursor of mature bone mineral and is involved in early stage of biomineralisation. While no positive effect on the ALP activity of hMSCs was observed in vitro, coated electrospun meshes combined with goat MSCs resulted in ectopic bone formation in mice, in contrast to the uncoated ones.

The source of bioactivity of Ca-P ceramics is considered to lie in dissolution/re-precipitation mechanism occurring on the surface and eventually leading to de novo bone deposition [11]. Post-implantation, a gradient between the Ca-P containing implants and surrounding tissue exists which leads to non equilibrium and dissolution of the coating to release constituent ions which are ultimately deposited as biological apatite. When the dissolution of OCP was studied in vitro and in vivo, a carbonated apatite coating was formed [8]. In the body, the fluids are replenished regularly and a high local concentration of ions is avoided whereas the culture conditions in the lab do not completely reflect the in vivo setting. A negative effect of calcium concentration on ALP activity has been observed in different cell types. Calcium negatively regulated the net release of ALP [12] in SaOS-2 and normal human bone cells. Decreased ALP activity that could be reversed by altering calcium concentration was observed in embryonic rat calvarial cells [13] and matrix vesicles showed a quantitative and temporal correlation between calcium accumulation and decline in ALP activity [14] Data from these studies were in accordance with the result of lower ALP activity in coated electrospun scaffolds. The reliance on ALP expression alone as an indicator of osteogenesis is very simplistic, especially when studying the effects of biomaterials. In a review on the topic of predictive value of in vitro assays to evaluate biomaterials for bone tissue engineering [15], it was emphasised that most of the current assays were developed mainly to assess the influence of growth 
factors, cytokines and hormones on the behaviour of cells and do not consider the biomaterial- medium interactions that could possibly result in a different response.

While hMSCs were chosen for in vitro studies owing to their clinical relevance, in vivo studies were performed with goat MSCs due to the following reasons. Differences in cell numbers of hMSCs between coated and uncoated scaffolds were observed after the culture period. In order to avoid implantation of cell-scaffold constructs with unequal amount of cells that might influence of the outcome of the in vivo experiment, it was decided to only allow cells sufficient time to attach and not to expand cells seeded on scaffolds in vitro. Previous experiments in our group have shown that hMSCs expanded in basic culture medium and seeded preoperatively on biphasic calcium phosphate (BCP) particles did not result in ectopic bone formation in a nude mouse model, in contrast to constructs based on goat MSCs [16]. Therefore, to verify the effectiveness of an OCP coating on electrospun fibres to induce bone formation, in vivo experiments were performed on constructs consisting of electrospun meshes and goat MSCs. Indeed, constructs built on coated scaffolds resulted in ectopic bone formation, unlike the ones built on the same electrospun meshes, but without the coating, which showed that the coating is able to improve the bioactivity of the polymeric mesh. Following this result, it is now of importance to demonstrate the relevance of this bioactivity in an orthotopic, and preferably load bearing animal model.

As a first step towards achieving that goal, it is necessary to have a load bearing three dimensional structure in millimetre scale or higher. Retaining the fibrous network that results from electrospinning would also be desirable to entrap cells and act as another layer of functionality in the micro/nano metre range. Therefore, in chapter 3, three dimensional porous scaffolds with high interconnectivity to provide mechanical support were fabricated with three dimensional fibre deposition (3DF) and combined with electrospun fibres to create an ECM like structure. Finally, the integrated scaffolds were coated in the same way as described in chapter 2 . The underlying rationale was to provide different types of cues (physical - electrospun fibres, chemical - coating and mechanical support-RP scaffold) and have a hierarchical scaffold with different levels of functionality. RP scaffolds fabricated from 
the same polymer have shown that it is possible to modulate mechanical properties of the scaffolds by modifying porosity, pore geometry and architecture [17-18], thus suggesting that it is possible to fabricate tailor-made scaffolds for certain tissue engineering applications.

With regard to metabolic activity and DNA content, no effect of the ESP layer was visible although it was observed that the electrospun fibres provided a favourable surface for cell attachment. Earlier studies performed on hierarchical scaffolds using chondrocytes [19-20] or an osteoblast cell line [21] mainly showed enhanced cell numbers for the integrated scaffolds only in the initial phase (up to 7 days or less). This suggests that the electrospun fibre matrices initially provide a more suitable surface for cell attachment and also increase the efficiency of seeding compared to a conventional 3DF scaffold by reducing the pore size (from few hundred micrometres for $3 \mathrm{DF}$ to few tens of micrometres for ESP) and acting like a sieve. Two other parameters - fibre density and frequency of electrospun layer occurrence could influence cell attachment and cell number. Fibre density can be increased with an increase in spinning time. It can be hypothesised that a denser mesh might trap more cells in the first electrospun layer during initial seeding thereby reducing the cell penetration to subsequent layers and a balance between providing physical cues through fibres and entrapping cells is required. Different strategies can be employed to tune fibre density that would in turn control the amount and spatial distribution of cells. One such strategy would be to vary fibre density over the height of the scaffold with the density increasing from the extremes to the centre of the scaffold or to have increase in fibre density from one end to the other. Such variation can be easily achieved by controlling the spinning time and could lead to a more uniform distribution of cells and also increase seeding efficiency. A more complex way to control mesh density and cell infiltration would be the fabrication of fibre meshes of different diameters where lower fibre diameters lead to a denser mesh than fibres of larger diameter.

Frequency at which electrospun layers occur in the construct is related to the ratio of RP to ESP layers. While earlier studies [19-21] chose to incorporate ESP layers at a higher frequency (usually ESP every one or two RP layers), the current 3DF + ESP scaffolds contained one ESP layer for 4 RP layers. The reason to reduce number of ESP layers 
was the subsequent coating process. Electrospun fibres provide a large surface and increasing the number of electrospun layers would provide larger areas for the deposition of the coating that might eventually decrease pore size and permeability of the scaffold, and therewith cell survival and growth. The combination of electrospun fibres and the coating might have led to low cell numbers in the ESP+3DF coated scaffolds compared to the $3 \mathrm{DF}$ coated and ESP $+3 \mathrm{DF}$ scaffolds. Therefore, it is important to control the amount of coating deposited and to achieve uniform thickness without agglomerates. Arafat et al. [22] proposed a coating method for carbonated HA in combination with gelatine that would produce a coating in a matter of hours. Oliviera et al. [23] demonstrated the use of a dynamic system to coat starch-polycaprolactone scaffolds. They observed no differences in coatings using static and dynamic conditions apart from an increased thickness using the dynamic method. The use of such a dynamic system would ensure that complex three dimensional structures can be coated uniformly as the constant flow would ensure that there is no agglomeration of particles at the pores. Further optimisation of the dynamic approach could lead to a reduced coating time and thickness, making the process time efficient.

In general, gene expression data showed that various early and late osteogenic markers had a higher expression in the hybrid scaffolds compared to $3 \mathrm{DF}$ scaffolds. In most cases, the OCP coating had a stronger positive influence on gene expression than the presence of the ESP layers, although this does not negate the importance of having an electrospun mesh due to reasons mentioned earlier. Therefore, possible improvements would involve modifying the electrospun mesh structure and possibly using a much larger pore size for the $3 \mathrm{DF}$ scaffolds thereby directing cell attachment predominantly to the fibre mesh. The results of this chapter suggest that cell fate can be controlled by using different types of physical (ESP fibres) and chemical (coating) cues.

\section{COMPOSITE SCAFFOLDS FOR ENHANCED OSTEOGENIC BEHAVIOUR}

$\mathrm{T}$ he fabrication of composites from either synthetic or natural polymers in combination with different types of Ca-P ceramics like HA and $\beta$ - TCP is an often used strategy to develop bone graft substitutes 
or scaffolds for tissue engineered constructs owing to the composition of bone, that consists of organic (collagen and other non-collagenous proteins) and inorganic (biological apatite) components. Expanding further on the theme of incorporating $\mathrm{Ca}-\mathrm{P}$ in scaffolds, composites were fabricated using various techniques. In chapter 4 , we fabricated composite scaffolds that resemble bone composition and fibrillar structure of extra cellular matrix (ECM) by incorporating collagen, HA or both components into PolyActive ${ }^{\mathrm{TM}}$, a synthetic polymer using electrospinning. Furthermore, we investigated the effects of incorporating collagen as agglomerate or a fully dispersed blend by modifying the solvent(s) used. When hMSCs were cultured on these constructs, they had the highest metabolic activity on the scaffold that contained HA and well dispersed collagen in addition to the polymer. Gene expression of osteogenic markers also revealed that the agglomerated scaffolds invariably had a lower expression compared to the well dispersed blend. Based on the study, it can be concluded that scaffolds fabricated with different components found in the bone alter the proliferation and gene expression of hMSCs. While this conclusion is to be expected and was the underlying rationale for fabrication of composites, another interesting observation was the outcome related to the mode of collagen distribution. This suggests that the mere presence of a certain component (collagen in this case) may not be sufficient to elicit the desired cellular response and the form in which it is distributed could play a vital role. In a recent study using electrospun PCL based composites [24] differences in mechanical properties and cell growth kinetics were also observed when the same composition of materials was dissolved in two different solvent systems. This difference was attributed to the use of different solvents that gave rise to electrospun scaffolds of different fibre dimensions (one order of magnitude) and pore sizes that eventually controlled cell infiltration and metabolic activity. In the study presented in this thesis we eliminated the influence of fibre diameter and pore sizes by choosing fibres of comparable characteristics and our conclusion is that the observed effect in terms of cellular and gene activity can be attributed to the distribution of collagen in agglomerate or fibrillar form.

Other key aspects in electrospinning of composites include the loading and dispersion of the ceramic particles and the change in mechanical properties of the resulting scaffold. Sonication [25] and addition of a 
surfactant [26] have been suggested as possible strategies to improve distribution of ceramic particles. Unequal distribution of ceramic within the scaffold could lead to variations in mechanical properties in different parts of the scaffold which, in turn, would lead to mechanically weak spots. Studies have shown that a low amount of ceramic provided mechanical support and reinforcement whereas higher amounts had a negative effect on mechanical properties like modulus and strength $[25,27]$. Therefore, it is of vital importance that amount of HA added to the scaffold is not very high so as to lead to scaffolds with poorer mechanical properties, and yet high enough to positively influence the bioactivity of the polymer into which it is incorporated. In this study, the effect of mechanical properties due to addition of different amounts of ceramic was not evaluated as only one concentration was used. Since a potential scaffold candidate in terms of cellular activity and gene expression has been identified, further steps could involve using different amounts of ceramic and/or collagen to study the mechanical and cellular behaviour of the next generation of scaffolds. Another point to be remembered is that the cell-scaffold constructs used in the study were cultured in cell culture media without the addition of commonly used supplements like dexamethasone that are added to induce osteogenesis of hMSCs. Therefore, it can be reasonably stated that the addition of collagen-I and HA enhances the metabolic activity and osteogenic potential of hMSCs when compared to polymer only electrospun scaffolds.

As discussed above, some fabricated composite electrospun fibres [28] have tensile properties comparable to cancellous bone (50 -500 MPa) [29] although, owing to the fibrous nature of the scaffolds, their ability to withstand compressive load is weak. Thus, despite the fact that electrospun composite scaffolds have demonstrated favourable cellular responses, other fabrication methods are called for in order to make the scaffolds applicable in load bearing applications. This issue was approached by extruding thin composite filaments of desired composition in a screw extruder and using these for $3 \mathrm{D}$ fibre deposition. It was possible to extrude composites with up to $15 \mathrm{wt}$ \% ceramic using the current system and nozzle, which is comparable to other RP techniques like FDM that have fabricated PCL-TCP scaffolds with 20 wt. \% TCP. From a fabrication perspective, the increase in ceramic loading to elicit a favourable biological response could be achieved by 
using a different extrusion system based on an auger-screw, thereby enabling the processing of highly viscous melts. All composites tested had modulus in the range of cancellous bone [30] and were comparable to those obtained with Ca-P containing composite scaffolds prepared by SLS [31] and FDM (20\% $\beta$-TCP ) [32] - a technique very similar to 3DF deposition and Precision Extrusion Deposition (25\% HA) [33].

As mentioned before, Ca-P ceramics derive their bioactivity from dissolution which releases calcium and phosphate ions into the medium or implant site, triggering further steps in bone formation [6, 34].In our study on composites, release of calcium from the different fabricated scaffolds was comparable (and low), which can be attributed to the method of scaffold fabrication. Ceramic in the composite scaffolds was present inside the struts of the 3DF scaffolds which plausibly slowed down the release of calcium thereby making the degradation of the polymer the main factor in determining release. One possible solution to this problem would be to fabricate scaffolds from polymers that allow faster dissolution of the ceramic leading to enhanced bioactivity. However, it has to be noted that a faster degradation of the polymer could also make the tissue engineered construct unstable and care must be taken while choosing an alternative. Another strategy to enhance dissolution is to increase the surface of the ceramic particles in contact with the medium or body fluids. Hence, fabricating an assembled composite which has ceramic directly in contact with medium would accelerate the degradation as compared to a conventional, monolithic composite in which the ceramic might be trapped inside the polymeric struts. Additionally, an increase in the amount of doped ceramic would also lead to higher release of ions into the surrounding environment and could potentially enhance the bioactivity. For this reason, the assembled composites provide an elegant solution as increasing the ceramic component in the scaffold can be achieved without limitations associated with fabrication equipment used for production of conventional composites.

Based on the rationale above, in chapter 5, two different methods to fabricate composites were compared. In order to maintain consistency in the two approaches, composites were fabricated from PA and $\mathrm{HA}$ and the resulting composite was designed to contain the same ratio of PA: HA. Conventional composites were prepared by extruding 
composite filaments of desired composition and used as feed for rapid prototyping. An alternative method used was to create hybrid composite scaffolds by assembling ceramic particles on to rapid prototyped polymeric scaffolds. Pillars were fabricated by pouring HA slurry into negative moulds fabricated using stereolithography and sintering the slurry. In terms of fabrication, the assembly approach offers several advantages. Since the ceramic loading is performed post rapid prototyping the problem of very high melt viscosities and clogging during scaffold production is negated. This approach allows incorporation of a larger amount of ceramic in the composite than would be possible in a conventional rapid prototyping set up. Using this approach, it would even be possible to obtain a scaffold that has an organic/inorganic material ratio comparable to natural bone (30\% polymer, $60 \%$ ceramic). The increase in ceramic amount can alter the mechanical properties of the scaffold as has been suggested in publications [35] and in our study, this was observed in the conventional composites. Although the assembled composite had a higher modulus than the polymeric scaffold, the difference was not significant. One possible cause could be the distribution of HA in the composite and further improvement in mechanical properties would be feasible by adding more pillars to the $3 \mathrm{DF}$ scaffolds with the assembled approach. An earlier study in our lab showed that it was also possible to tune mechanical properties of assembled scaffolds by using ceramic particles of different shapes [36] viz. - pillar, truncated cone and sphere. Apart from mechanical properties, the increase in ceramic content has also been shown to improve biological performance of composites [35, 37]. Metabolic activity of cells on the assembled composites was significantly higher than on conventional composites. Whereas in the conventional composite, the $\mathrm{HA}$ is distributed in the bulk and may be released slowly, the use of ceramic pillars in the assembled composites provided more contact with the culture media leading to higher release of $\mathrm{Ca}$ and $\mathrm{P}$ ions, which was confirmed by the ion release results. It has also been shown that phosphate induces OP expression and the increased level of OP expression seems to lend some credence to this theory. HA, the ceramic used in this study is one of the slow degrading Ca-P ceramics and it could be combined with or replaced by $\beta$ - TCP, the more resorbable Ca-P phase [38] to further increase ion release into the system if desired. Other alternatives like Mg-substituted HA, that resembles the bone mineral 
more closely and has faster degradation rates compared to stoichiometric HA [39] are currently being explored. Another advantage of using an assembly approach to fabrication of ceramics is the possibility to incorporate proteins and growth factors that can further improve bone formation. Ceramic materials have been previously used as carriers of BMP-2 [40] and the fabrication of the ceramic pillars separately allows for the addition of biological compounds that would otherwise be degraded during extrusion process (conventional one step RP fabrication). In conclusion, an assembly approach to composite fabrication offers advantages of increased loading of ceramic, better availability of ceramic surface to body fluids and cells, with consequent effects on bioactivity of the construct and the possibility of incorporating growth factors and proteins.

\section{ALTERING CELL BEHAVIOUR USING SURFACE TOPOGRAPHY}

While the first part of this thesis focused on the development of polymeric scaffolds that incorporated $\mathrm{Ca}-\mathrm{P}$ or electrospun fibres in order to add chemical and micro-nano structural cues respectively to three dimensional RP scaffolds, the focus of the last part of this thesis was the use of surface topography as a method to alter cell behaviour and fate. Plasma treatment offers a simple and inexpensive method to treat surfaces and studies have shown the control over protein adsorption and cell attachment and proliferation [41-42] by plasma treating polymeric surfaces. Therefore, in chapter 6 , oxygen plasma treatment was performed on electrospun scaffolds to alter the physico-chemical properties which in turn were expected to elicit a favourable biological response. Plasma treatment increased fibre roughness and protein adsorption although no difference in metabolic activity of hMSCs was observed during the culture period of seven days. However, gene expression of different osteogenic markers was upregulated and significant differences between treated and untreated surfaces were observed. Surface modification by plasma treatment offers several advantages. By choosing the appropriate gas used for etching (oxygen, air, ammonia etc.), different functional groups can be generated on the surface (carboxyl, amine) that can either alter surface properties like wettability and roughness thereby improving biocompatibility or cell adhesion or provide sites for further covalent binding of bioactive molecules. 
The positive effects of using various plasma treatments such as air [43] and argon [44] increased mineralisation of human foetal osteoblasts. Chapter 6 adds to the existing literature by providing a method to tailor roughness based on treatment time and by elucidating the response of osteogenic markers to such treated scaffolds. Owing to the simple and time efficient nature of this treatment, it could routinely be used to treat electrospun scaffolds prior to subsequent processing like biomimetic coatings (chapters 2 and 3 ). Cell attachment in 3DF scaffolds that generally have low cell attachment on the struts could also be improved by plasma treatment. However, while treating a combined ESP $+3 \mathrm{DF}$ scaffold that has features in different orders of magnitude (200$300 \mu \mathrm{m}$ struts and few tens of micrometre fibres), it must be noted that excessive treatment times might lead to disintegration of electrospun fibre structure due to effects of localised heating.

While plasma treatment provides a simple and inexpensive method to treat surfaces, a change in surface morphology is inevitably coupled to a change in chemical composition even when non reactive gases like argon are used. It would therefore be beneficial to have a process that decouples surface topography and chemical composition and this was one of the important factors that initiated the research in chapter 7. Studies have shown that by controlling surface topographies one can modulate cellular activity. Dalby et al. [45] showed that, by using nanoscale disorder, it was possible to stimulate mineral deposition by hMSCs without the use of osteogenic supplements in 2D. Based on the idea of patterns and topographies altering cell behaviour, we combined electrospinning with an imprinting process to create three dimensional patterned substrates with different topographies. Chapter 7 shows the proof of concept for patterning electrospun fibres with custom made patterns on different scales, shapes and tones. These scaffolds were imprinted using a Nano Imprint Lithography machine in a short process (60 seconds) performed at physiological temperatures. The results presented in the chapter showed the feasibility of patterning electrospun fibres on a single fibre level while most patterning of electrospun fibres has been performed on a larger scale [46-47]. As discussed in the relevant chapter, the use of physiological temperatures provides the possibility of incorporating biological materials like collagen, BMP-2 and other growth factors that are known to help in bone regeneration. 
In the recent years, the use of nanotechnology in tissue engineering has increased and various methods exist for fabricating nanoscale surfaces [48]. Fundamental research on cellular response to different topographies has been performed by different groups and screening methods similar to the ones used in pharmaceutical industry are being employed to screen a wide variety of surfaces [49] or biomaterials [50-51] simultaneously. However, these studies are predominantly performed on two dimensional surfaces and we believe that this proof of concept study provides a platform to study topographical effects in a three dimensional scaffold and to implement "hits" from two dimensional screens on to a three dimensional scaffold to validate the proposed cell response. While the possibility of having microscale arrays of different patterns were shown in the chapter, we also envision that, in the future, it would be possible to fabricate millimetre scale screening systems with discrete patterns.

\section{TECHNOLOGICAL IMPROVEMENTS AND FUTURE POSSIBILITIES}

$\mathrm{W}$ hile electrospinning is a very versatile technique to fabricate scaffolds, it is important to have stable ambient conditions (temperature, humidity) as they can affect the outcome of the spinning process [52]. Since it is costly to adapt the ambient conditions of the labs in which electrospinning is performed, we developed a climate controlled electrospinning setup to ensure stability and reproducibility during processing. This control over ambient conditions can also be used as a tool to intentionally modify properties of the fibres, such as morphology. In addition to control over ambient conditions, the newly developed system also consists of a computer controlled XYZ arm which can be used to obtain homogenous electrospun meshes.

One application of electrospun fibres is in the form of reservoirs for various factors like drugs, proteins and small molecules. The release of such compounds can be tailored based on choice of polymer, fibre diameter and morphology. Co-axial electrospinning is the process of producing shell-core fibres from two different solutions. Biological factors that cannot be easily spun using benign solvents can be spun using co-axial spinning when an electrospinnable polymer is used as a guide. Few studies have already shown the feasibility of incorporating 
biological agents in shell-core electrospun fibres for different tissue engineering applications [53-54]. It is possible to think of a degrading shell that provides cues for early osteogenic differentiation and a stable, slower degrading core that provides support and contains cues for later differentiation. Another attractive option would be the incorporation of salts of trace elements like strontium, magnesium and carbonate that could serve the dual role of enhancing osteogenic behaviour and improving the electrospinning by contributing to the electrical conductivity of the solution. While requirements for bone substitutes vary depending on the application, it is clear that a combination of scaffold fabrication methods and techniques can result in a substitute that could potentially fulfil necessary requirements in comparison to conventional fabrication methods suggesting that the whole is greater than the sum of parts.

\section{REFERENCES}

1. Barrere F, van der Valk CM, Dalmeijer RAJ, Meijer G, van Blitterswijk CA, de Groot K, et al. Osteogenecity of octacalcium phosphate coatings applied on porous metal implants. Journal of Biomedical Materials Research Part A 2003;66A(4):779-788.

2. de Groot K, Geesink R, Klein CP, Serekian P. Plasma sprayed coatings of hydroxylapatite. J Biomed Mater Res 1987;21(12):13751381 .

3. Kumar M, Dasarathy H, Riley C. Electrodeposition of brushite coatings and their transformation to hydroxyapatite in aqueous solutions. J Biomed Mater Res 1999;45(4):302-310.

4. Schmidmaier G, Wildemann B, Schwabe P, Stange R, Hoffmann J, Sudkamp NP, et al. A new electrochemically graded hydroxyapatite coating for osteosynthetic implants promotes implant osteointegration in a rat model. Journal of Biomedical Materials Research 2002;63(2):168-172.

5. Geesink RG. Hydroxyapatite-coated total hip prostheses. Twoyear clinical and roentgenographic results of 100 cases. Clin Orthop Relat Res 1990(261):39-58.

6. Geesink RG, de Groot K, Klein CP. Bonding of bone to apatite- 
coated implants. J Bone Joint Surg Br 1988;70(1):17-22.

7. Geesink RGT, Hoefnagels NHM. 6-Year Results of Hydroxyapatite-Coated Total Hip-Replacement. Journal of Bone and Joint Surgery-British Volume 1995;77B(4):534-547.

8. Barrere F, van der Valk CM, Dalmeijer RAJ, van Blitterswijk CA, de Groot K, Layrolle P. In vitro and in vivo degradation of biomimetic octacalcium phosphate and carbonate apatite coatings on titanium implants. Journal of Biomedical Materials Research Part A 2003;64A(2):378-387.

9. Liu YL, Hunziker EB, Layrolle P, De Bruijn JD, De Groot K. Bone morphogenetic protein 2 incorporated into biomimetic coatings retains its biological activity. Adv Exp Med Biol 2004;10(1-2):101108.

10. Yang L, Perez-Amodio S, Barrere-de Groot FY, Everts V, van Blitterswijk CA, Habibovic P. The effects of inorganic additives to calcium phosphate on in vitro behavior of osteoblasts and osteoclasts. Biomaterials 2010;31(11):2976-2989.

11. Ducheyne P, Beight J, Cuckler J, Evans B, Radin S. Effect of Calcium-Phosphate Coating Characteristics on Early Postoperative Bone Tissue Ingrowth. Biomaterials 1990;11(8):531-540.

12. Anh DJ, Dimai HP, Hall SL, Farley JR. Skeletal alkaline phosphatase activity is primarily released from human osteoblasts in an insoluble form, and the net release is inhibited by calcium and skeletal growth factors. Calcif Tissue Int 1998;62(4):332-340.

13. Yoshimura Y, Hisada Y, Suzuki K, Deyama Y, Matsumoto A. Effect of a low-calcium environment on alkaline phosphatase activity in embryonic rat calvarial bone cells in culture. Arch Oral Biol 1996;41(1):41-45.

14. Genge BR, Sauer GR, Wu LN, McLean FM, Wuthier RE. Correlation between loss of alkaline phosphatase activity and accumulation of calcium during matrix vesicle-mediated mineralization. J Biol Chem 1988;263(34):18513-18519.

15. Habibovic P, Woodfield T, de Groot K, van Blitterswijk C. Predictive value of in vitro and in vivo assays in bone and cartilage repair - What do they really tell us about the clinical performance? Adv Exp 
Med Biol 2006;585:327-360.

16. Siddappa R, Martens A, Doorn J, Leusink A, Olivo C, Licht $\mathrm{R}$, et al. cAMP/PKA pathway activation in human mesenchymal stem cells in vitro results in robust bone formation in vivo. Proc Natl Acad Sci U S A 2008;105(20):7281-7286.

17. Moroni L, de Wijn JR, van Blitterswijk CA. Three-dimensional fiber-deposited PEOT/PBT copolymer scaffolds for tissue engineering: Influence of porosity, molecular network mesh size, and swelling in aqueous media on dynamic mechanical properties. Journal of Biomedical Materials Research Part A 2005;75A(4):957-965.

18. Moroni L, de Wijn JR, van Blitterswijk CA. 3D fiber-deposited scaffolds for tissue engineering: Influence of pores geometry and architecture on dynamic mechanical properties. Biomaterials 2006;27(7):974-985.

19. Kim G, Son J, Park S, Kim W. Hybrid Process for Fabricating 3D Hierarchical Scaffolds Combining Rapid Prototyping and Electrospinning. Macromol Rapid Comm 2008;29(19):1577-1581.

20. Moroni L, Schotel R, Hamann D, de Wijn JR, van Blitterswijk CA. 3D fiber-deposited electrospun integrated scaffolds enhance cartilage tissue formation. Advanced Functional Materials 2008;18(1):5360 .

21. Martins A, Chung S, Pedro AJ, Sousa RA, Marques AP, Reis RL, et al. Hierarchical starch-based fibrous scaffold for bone tissue engineering applications. J Tissue Eng Regen Med 2009;3(1):37-42.

22. Arafat MT, Lam CX, Ekaputra AK, Wong SY, Li X, Gibson I. Biomimetic composite coating on rapid prototyped scaffolds for bone tissue engineering. Acta Biomater 2010.

23. Oliveira AL, Costa SA, Sousa RA, Reis RL. Nucleation and growth of biomimetic apatite layers on 3D plotted biodegradable polymeric scaffolds: effect of static and dynamic coating conditions. Acta Biomater 2009;5(5):1626-1638.

24. Patlolla A, Collins G, Arinzeh TL. Solvent-dependent properties of electrospun fibrous composites for bone tissue regeneration. Acta Biomaterialia 2010;6(1):90-101. 
25. Jose MV, Thomas V, Xu Y, Bellis S, Nyairo E, Dean D. Aligned bioactive multi-component nanofibrous nanocomposite scaffolds for bone tissue engineering. Macromol Biosci 2010;10(4):433-444.

26. Kim HW, Lee HH, Knowles JC. Electrospinning biomedical nanocomposite fibers of hydroxyapaite/poly(lactic acid) for bone regeneration. Journal of Biomedical Materials Research Part A 2006;79A(3):643-649.

27. Yang F, Both SK, Yang X, Walboomers XF, Jansen JA. Development of an electrospun nano-apatite/PCL composite membrane for GTR/GBR application. Acta Biomater 2009;5(9):3295-3304.

28. Jose MV, Thomas V, Xu YY, Bellis S, Nyairo E, Dean D. Aligned Bioactive Multi-Component Nanofibrous Nanocomposite Scaffolds for Bone Tissue Engineering. Macromol Biosci 2010;10(4):433-444.

29. Murugan R, Ramakrishna S. Development of nanocomposites for bone grafting. Compos Sci Technol 2005;65(15-16):2385-2406.

30. Athanasiou KA, Zhu CF, Lanctot DR, Agrawal CM, Wang X. Fundamentals of biomechanics in tissue engineering of bone. Adv Exp Med Biol 2000;6(4):361-381.

31. Duan B, Wang M. Customized Ca-P/PHBV nanocomposite scaffolds for bone tissue engineering: design, fabrication, surface modification and sustained release of growth factor. J R Soc Interface 2010;7:S615-S629.

32. Zhou YF, Hutmacher DW, Varawan SL, Lim TM. In vitro bone engineering based on polycaprolactone and polycaprolactone-tricalcium phosphate composites. Polym Int 2007;56(3):333-342.

33. Shor L, Guceri S, Wen XJ, Gandhi M, Sun W. Fabrication of three-dimensional polycaprolactone/hydroxyapatite tissue scaffolds and osteoblast-scaffold interactions in vitro. Biomaterials 2007;28(35):5291-5297.

34. Hanawa T, Kamiura Y, Yamamoto S, Kohgo T, Amemiya A, Ukai $\mathrm{H}$, et al. Early bone formation around calcium-ion-implanted titanium inserted into rat tibia. J Biomed Mater Res 1997;36(1):131-136.

35. Kim K, Dean D, Lu A, Mikos AG, Fisher JP. Early osteogenic signal expression of rat bone marrow stromal cells is influenced 
by both hydroxyapatite nanoparticle content and initial cell seeding density in biodegradable nanocomposite scaffolds. Acta Biomater 2011;7(3):1249-1264.

36. Moroni L, Hamann D, Paoluzzi L, Pieper J, de Wijn JR, van Blitterswijk CA. Regenerating articular tissue by converging technologies. PLoS One 2008;3(8):e3032.

37. Cao H, Kuboyama N. A biodegradable porous composite scaffold of PGA/beta-TCP for bone tissue engineering. Bone 2010;46(2):386395.

38. Damien CJ, Parsons JR. Bone graft and bone graft substitutes: a review of current technology and applications. J Appl Biomater 1991;2(3):187-208.

39. Landi E, Logroscino G, Proietti L, Tampieri A, Sandri M, Sprio S. Biomimetic Mg-substituted hydroxyapatite: from synthesis to in vivo behaviour. Journal of Materials Science-Materials in Medicine 2008;19(1):239-247.

40. Sohier J, Daculsi G, Sourice S, de Groot K, Layrolle P. Porous beta tricalcium phosphate scaffolds used as a BMP-2 delivery system for bone tissue engineering. J Biomed Mater Res A 2010;92(3):11051114.

41. Kirkpatrick CJ, Santos MI, Pashkuleva I, Alves CM, Gomes ME, Fuchs S, et al. Surface-modified 3D starch-based scaffold for improved endothelialization for bone tissue engineering. J Mater Chem 2009;19(24):4091-4101.

42. Yang YZ, Cavin R, Ong JL. Protein adsorption on titanium surfaces and their effect on osteoblast attachment. Journal of Biomedical Materials Research Part A 2003;67A(1):344-349.

43. Venugopal J, Low S, Choon AT, Kumar AB, Ramakrishna S. Electrospun-modified nanofibrous scaffolds for the mineralization of osteoblast cells. J Biomed Mater Res A 2008;85(2):408-417.

44. Yang F, Wolke JGC, Jansen JA. Biomimetic calcium phosphate coating on electrospun poly (epsilon-caprolactone) scaffolds for bone tissue engineering. Chem Eng J 2008;137(1):154-161.

45. Dalby MJ, Gadegaard N, Tare R, Andar A, Riehle MO, Herzyk 
$\mathrm{P}$, et al. The control of human mesenchymal cell differentiation using nanoscale symmetry and disorder. Nature Materials 2007;6(12):9971003.

46. Zhang DM, Chang J. Patterning of electrospun fibers using electroconductive templates. Advanced Materials 2007;19(21):3664+ .

47. Zhang DM, Chang J. Electrospinning of Three-Dimensional Nanofibrous Tubes with Controllable Architectures. Nano Lett 2008;8(10):3283-3287.

48. Yang Y, Leong KW. Nanoscale surfacing for regenerative medicine. Wires Nanomed Nanobi 2010;2(5):478-495.

49. Lovmand J, Justesen E, Foss M, Lauridsen RH, Lovmand M, Modin C, et al. The use of combinatorial topographical libraries for the screening of enhanced osteogenic expression and mineralization. Biomaterials 2009;30(11):2015-2022.

50. Anderson DG, Levenberg S, Langer R. Nanoliter-scale synthesis of arrayed biomaterials and application to human embryonic stem cells. Nat Biotechnol 2004;22(7):863-866.

51. Anderson DG, Putnam D, Lavik EB, Mahmood TA, Langer R. Biomaterial microarrays: rapid, microscale screening of polymer-cell interaction. Biomaterials 2005;26(23):4892-4897.

52. De Vrieze S, Van Camp T, Nelvig A, Hagstrom B, Westbroek P, De Clerck K. The effect of temperature and humidity on electrospinning. J Mater Sci 2009;44(5):1357-1362.

53. Jiang HL, Hu YQ, Li Y, Zhao PC, Zhu KJ, Chen WL. A facile technique to prepare biodegradable coaxial electrospun nanofibers for controlled release of bioactive agents. Journal of Controlled Release 2005;108(2-3):237-243.

54. Leong KW, Liao IC, Chew SY. Aligned core-shell nanofibers delivering bioactive proteins. Nanomedicine-Uk 2006;1(4):465-471. 


\section{Acknowledgements}

Feeling gratitude and not expressing it is like wrapping a present and not giving it.

- William Arthur Ward 
The $\mathrm{PhD}$ has been an interesting, difficult, at times frustrating and ultimately a satisfying experience. Lot of people have contributed and helped me in many different ways and I would like to convey my sincere thanks to them.

I would first like to thank my promoter - Prof. Clemens van Blitterswijk and my supervisor - Dr. Pamela Habibovic. Clemens, I vividly remember our first meeting during my interview in Bilthoven and the discussions we had during my first year of PhD. I was amazed at the rate at which you came up with ideas and suggestions, and how a 30 minute meeting would give me work for 3-6 months. I was very happy when you took the time from your extremely busy schedule to help me look at histology slides. Thank you very much for the trust and faith in me and for giving me the freedom to choose my own path. Pamela - thank you for the supervision and your confidence in me. You let me pursue ideas even when they were not directly in your line of research and ultimately, we could combine whatever I wanted to do with your expertise. Your comments during the thesis writing were excellent and you were quick to send them back. Although I had to work more to ensure that your comments were answered satisfactorily, I realise that the thesis has improved and it was time well spent. Thanks for also agreeing to translate my summary into samenvatting amidst your busy schedule.

I would also like to thank my former boss, Prof. Dietmar Hutmacher at the National University of Singapore. The time I spent in the group at NUS laid the foundation for my PhD. Dietmar, I am really grateful to you for the opportunity to work in your group and for advising me when I was looking for PhD positions. I hope we get a chance to meet once again. To all my former colleagues and friends, I really enjoyed your company and was fortunate to have met some really nice people.

Lorenzo - I do not know where to begin, so I will start chronologically. Thanks a lot for introducing me to the technologies that form the basis for this thesis. The home- built spinning setup gave me a chance to do my first spinning experiments and the first "shock" stories. I was glad to build on it further and hope we have improved things in the last few years. You were always there - either on gmail chat or in person throughout my $\mathrm{PhD}$ and I immensely enjoy(ed) all our chats on scaffolds, movies, 24, some nice Italian words and a lot more. I was very happy that you took the effort to come to India for my wedding and 
also my advice on not to drive during your visit : ). Once you were back in TR, we had very long and interesting discussions almost every evening. At times during the thesis writing, when I felt low, I would call you for some inspiration and motivation which I always received. Thanks for being a wonderful brother to Renuka and ensuring that one of you always kept reminding me that I had a thesis to finish. I am glad that I had the opportunity to meet you and thank you very much for being my friend, philosopher and guide. Grazie!

Andre, you are the nicest person I have met till date and I don't think there will be any competitors in the future. Starting with the animal course in Utrecht during my first year, we spent a lot of time together and I really enjoyed it. Thank you for all the nice conversations we continue to have via VOIP. The photoshoots around the campus, discussions on photography and the fight between Nikon and Canon were always nice. I was surprised at your willingness to try spicy food and was glad that you enjoyed it. Thanks a lot for the wonderful bottles of Porto wine. Thank you very much for agreeing to be my paranymph and for flying all the way from Portugal for me. I couldn't ask for anything more!

To my office mates - Nico, Gus and Hemant, our office was the coolest if not cleanest. Nico, although we took the bus to Paris during my first month as a $\mathrm{PhD}$ (I thought you were getting down on our return, really!), we began to talk a lot more after I moved to your office. I really admire your determination and the way you planned your experiments during the $\mathrm{PhD}$. Thank you for asking me to help with the Sonic paper and for the really nice publication. It was a long and crazy day in December. You have unique tastes and I enjoyed our conversations on movies, photography and a lot of other things and always looked forward to watching your recommendations. My appreciation of your music skills increased a lot when I couldn't get any sound out of the saxophone. Thank you for giving us company in Den Bosch where we did not have any friends. We really enjoyed your company and there will always be room in our home for you wherever we go. Thank you very much for being my paranymph and for the great company. Hemant - thanks a lot for the wonderful food. We will never forget the time when you fed us at midnight on our return from a vacation. Thank you for the company in the lab during the late hours and in the weekends which made things bearable and for the regular walks to the vending machine every evening. You are extremely passionate about 
work and will succeed wherever you go. All the best! Gus -you were the most organised and possibly, the most responsible person in our office. You were also the most resourceful - bringing in the chocolates and the fridge. Thank you for being my bioplotter-buddy and for being the sane and no-nonsense voice in the office. All the best with the start-up and I wish you all the best for the biggest job you are ever going to have.

To my students... Peter, you were my first student and we started work on the home-built setup trying to figure out things. I hope you had a nice experience. Celia and Diogo, thanks a lot for your help during the $\mathrm{PhD}$. Both of you came to Twente during my last year of $\mathrm{PhD}$ and really helped me wrap up some studies. Thanks for putting up with me during your time in the TR group and I wish you all the best for the future. Kristian, although you were not directly my student, we spent a lot of time discussing electrospinning and your project. I hope I was of some help to you. Nils - it was really nice of you to volunteer help at a time when I couldn't be at Twente. Thank you very much for all the staining that you did and I do not know how we would have managed without you!

Roman, your passion for research and your knowledge of almost all things under the sun is simply amazing! We started the imprinting study after one of our long after office-hour chats and although it was quite frustrating at times, we learnt a lot. Thank you for all the time you spent in the clean room and the extremely thorough comments while preparing the manuscript. I really enjoyed our long conversations, especially in the evening at the MENSA canteen. Thanks also for the cashewnuts which gave me the much needed extra energy during the long evenings in the lab. I still haven't figured out how you manage to survive on yoghurt and cashews! Joyce - it was a nice co-incidence that I met you in Singapore a few months before my move to Enschede. It was very nice of you to come to the train station to pick me up in Enschede and to give me a bike to use from my 1 st day. It is always good to know someone in a new place and I cannot thank you enough for the help during the early stages. Thanks for introducing me to DIOK in Twente where I had a great time. Hugo - thanks for teaching me a few words in Portuguese although it might make some people flinch. Thanks for all the tennis games and I hope that you will someday figure out that I let you win ;). I hope you realise that not all Indian food is spicy and that you should extend your scientific curiosity to the palate. Ram - we met 
briefly during my interview in Bilthoven and it was cool to have you around although you were saying cAMP in every other sentence. We were developing into a very good doubles team when you got injured. It was a shame we couldn't play together anymore but I really enjoyed our badminton time. Jeroen - you were the first PhD I met when you gave me the tour of the labs in Bilthoven. It was nice to share the office with you at the start of my $\mathrm{PhD}$ and to talk about photography and the cool experiments you were trying with your camera. Thanks also for being my first translator. Anouk - you were always patient, never angry and ready to help in the TC lab. If you have handled all of us, Faron should not be too difficult! Thanks for the PCRs and for all your help during my stay in the lab.

Liang - thank you for showing me the coating process that has led to two chapters in this thesis. I was really honoured when you asked me to be your paranymph. Hope you are doing well in China. Thanks to Charlene for the XRD and FT-IR measurements, Bjorn for helping me in the clean room, Ana for the PCRs in the coating study, Niloofar for the release experiments and Mijke for the contact angle measurements. Chris and Nicole - thanks a lot for your help when we moved from Enschede and the generally nice chats. Aliz, thank you for all the Tiramisu. Anindita, I really admire(d) the way you managed your PhD - shuttling between lab, day-care and home. Good luck with the defense and we will catch up in Eindhoven. Jeroen (L) - thanks for all the translation you did and the generally crazy chats we had from time to time. Jun - thanks for the Wii invites and all the best for the future. Paul - thanks for all the interesting emails and discussions we have been having in the last few months related to electrospinning. I am really happy that you are putting the new set-up to good use. Good luck with the experiments! Aart - thank you very much for the introduction to the SEM and EDX which I ended up using extensively during the PhD. Yuan and Davide, thanks for providing me with the HA and for helping me with the sintering and slurry preparations. Jan and Marcel, thank you very much for the discussions and advice you provided during the course of the PhD. To all the other colleagues in TR-past and present, thank you very much.

Martin Bennink and Kees, thank you for the collaboration for the plasma treatment chapter and for helping us with the AFM measurements. My work with electrospinning and the bioplotter meant that I spent 
a lot of time in the 1st floor near the PBM group. Piet - I will never forget our first meeting when I came to ask you for some PEO. You walked with me to all the PBM labs in the Zuidhorst and then took me to Langezijds and searched all the cabinets for me. Thanks for all the interesting discussions about electrospinning collagen. I am thankful to Zlata, Marc Ankone and Anita for all their help and assistance in helping me find the things I needed and for solving any lab related issues during the PhD. Special thanks to former PhDs in the PBM group - Ferry, Siggi and Erhan for showing me how to use some equipment in their labs. Thanks to the people from TCO - Dominic, Geert and others who helped me build and/or fix equipment.

Audrey, thank you very much for all the help you did during and after my stay. I don't know how I would have managed the last stages of the thesis submission and logistics without your help and hope I did not trouble you too much. Thank you very much.

It was not all work during the $\mathrm{PhD}$. I had a great time playing badminton at DIOK. It was after badminton one day that I chanced upon some people playing chess at the sportscenter and ended up playing 3 years for my club SV Drienerlo. Special thanks to Sander, Herwin, Robin, Rob, Daan and David for all the games ranging from blitz to bughouse. To the members of the indoor cricket group, thanks for the exciting matches and the passionate discussions on how our teams and players fared.

To my friends and well wishers outside the lab, Anand and Suba thanks for the dinners, car-rides and your willingness to help us at all times. Vishnu - thanks a lot for all the information you have provided over the years and for the coffee-chats during the day and weekends. Seth, Vishi and Akki - together with Andy, we had lots of fun during the Westerstraat parties and at Hengelo cricket, not to forget the summer lake party. Thank you for the good times. Ganesh, Karthika (and Nirupa) - thank you for the get togethers and festivities you arranged and all the help you have done and continue to do for us. CP- thanks a lot for the interesting phone conversations. Juan and Sandra, thanks for always being warm hosts. Juan, I hope you will one day finish reading the book I gave you :) Vicky - thanks for giving Renuka good company which ensured that she did not notice my absence so much! Many thanks to the two lawyers for teaching us words like "internally displaced". Detlef and Cornelia, it was nice to reconnect in Europe af- 
ter Singapore and we have thoroughly enjoyed our time with you and the kids. Narasimhan mama and Kamala maami, thank you for helping us in Geneva during a difficult time and for taking the role of our family in Europe. To my schoolmates, for the daily-spam ritual that always cheered me up. To my colleagues at QTIS/e and TU/e, thank you very much for the interesting discussions and support during the past year.

Appa and Amma - thank you for letting me choose my own path. You have never said no to any of my professional choices, even if it meant staying away from you for a long time. Thanks a lot for the million prayers. Thank you for everything you have done. To my brother Ram, thank you for sharing your experiences in research and giving valuable advice whenever I asked. To my in-laws, thank you very much for your confidence, support and trust in me - be it with the PhD or your daughter. Ramadhyani - thanks for the discussions on cricket and tennis and for your regular movie reviews.

Renuka, actions speak louder than words and whatever I write here can never do complete justice to the sacrifices you have made during and for my PhD. Thank you for your support, patience and belief. Thank you for having food ready when I returned home at odd hours, even if it was on a day when you had to travel 4 hours by train to Utrecht for your study. Thank you for being a friend, parent and partner during my most challenging phase and for helping me get through it. This thesis is as much yours as it is mine - you have the better half! Thank you for everything and I look forward to spending more time together. Love you!

In case I have missed anyone, Sorry and Thank you!

- Anand 


\section{CURRICULUM VITAE}

Anandkumar Nandakumar was born on the 29th of September, 1981 in Madras (Chennai), India. He grew up in Madras till he graduated with a Bachelor's degree in Chemical Engineering (with distinction) from the University of Madras. In 2002, he received a fellowship to pursue a Master's program in Molecular Engineering in the Singapore - MIT Alliance at the National University of Singapore. Upon graduation, he worked as a research assistant in different universities in Singapore on various tissue engineering applications. In October 2006, he started his $\mathrm{PhD}$ in the department of Tissue re-

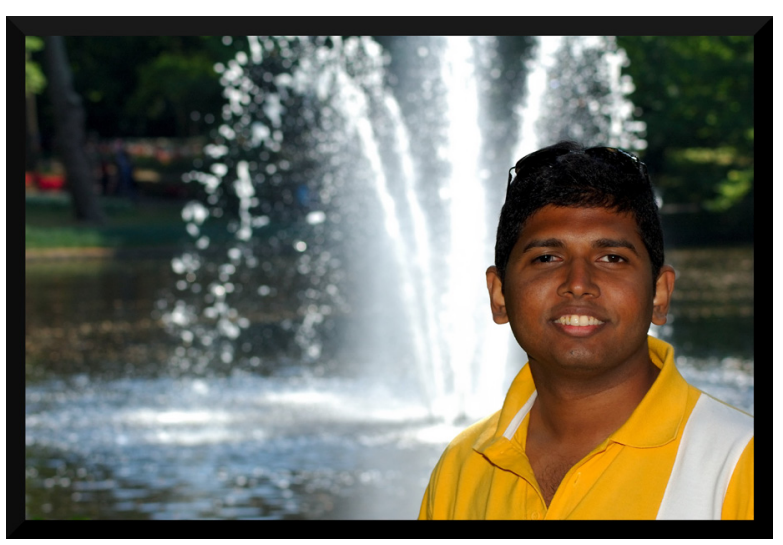
generation, University of

Twente under the supervision of Prof. Dr. C.A van Blitterswijk and Dr. Pamela Habibovic. His research was on scaffold fabrication for bone tissue engineering the results are described in this thesis. Since October 2010, he has been working as a Senior Researcher at QTIS/e BV, a tissue engineering company focussing on cardiovascular applications. Anand enjoys travel, photography, chess and watching cricket. 
